\title{
Geografia das telecomunicações no Brasil
}

\author{
Paulo Fernando Jurado da Silva
}

SILVA, PFJ. Geografia das telecomunicações no Brasil [online]. São Paulo: Editora UNESP; São Paulo: Cultura Acadêmica, 2015, 306 p. ISBN 978-85-7983-670-1. Available from SciELO Books $<\underline{\text { http://books.scielo.org }>\text {. }}$

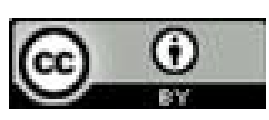

All the contents of this work, except where otherwise noted, is licensed under a Creative Commons Attribution 4.0 International license.

Todo o conteúdo deste trabalho, exceto quando houver ressalva, é publicado sob a licença Creative Commons Atribição $\underline{4.0}$.

Todo el contenido de esta obra, excepto donde se indique lo contrario, está bajo licencia de la licencia Creative Commons $\underline{\text { Reconocimento } 4.0 .}$. 


\section{Geografia dAS TELECOMUNICAÇÕES NO BRASIL}


CONSELHO EDITORIAL ACADÊMICO

Responsável pela publicação desta obra

\author{
Eda Maria Goes \\ José Tadeu Garcia Tommaselli \\ Rosangela Aparecida de Medeiros Hespanhol \\ Eduardo Paulon Girardi \\ Raphael Fernando Diniz \\ Baltazar Casagrande
}




\section{PAULO FERNANDO JURADO DA SILVA}

\section{GeOGRAFIA DAS TELECOMUNICAÇÕES NO BRASIL}


(C) 2015 Editora Unesp

\section{Cultura Acadêmica}

Praça da Sé, 108

01001-900 - São Paulo - SP

Tel.: (0xx11) 3242-7171

Fax: (0xx11) 3242-7172

www.culturaacademica.com.br

feu@editora.unesp.br

CIP - BRASIL. Catalogação na Publicação

Sindicato Nacional dos Editores de Livros, RJ

S585g

Silva, Paulo Fernando Jurado da

Geografia das telecomunicações no Brasil [recurso eletrônico]/ Paulo Fernando Jurado da Silva. - 1. ed. - São Paulo: Cultura Acadêmica, 2015.

recurso digital

Formato: epub

Requisitos do sistema: Adobe Acrobat Reader

Modo de acesso: World Wide Web

Inclui bibliografia

ISBN 978-85-7983-670-1 (recurso eletrônico)

1. Telecomunicações - Brasil. 2. Política de telecomunicações - Brasil.

3. Comunicação de massa - Brasil. 4. Tecnologia da informação - Brasil.

5. Livros eletrônicos. I. Título.

$15-27093$

CDD: 384.50981

CDU: 654(81)

Este livro é publicado pelo Programa de Publicações Digitais da Pró-Reitoria de Pós-Graduação da Universidade Estadual Paulista "Júlio de Mesquita Filho" (Unesp)

Editora afiliada:

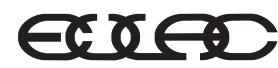

Asociación de Editoriales Universitarias de América Latina y el Caribe

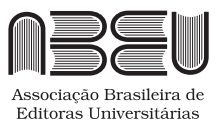




\section{ApresentAÇÃo e AGRAdeCIMENTOS}

Este livro é o resultado de atividade de pesquisa, referente ao período de 2011 a 2014, no Programa de Pós-Graduação em Geografia da Faculdade de Ciências e Tecnologia, Unesp (Universidade Estadual Paulista), Câmpus de Presidente Prudente, quando cursei doutorado sob a orientação de Eliseu Savério Sposito. É também fruto de experiência de investigação na Universidad de Buenos Aires, Pontificia Universidad Católica de Chile e de doutorado-sanduíche, cumprido na Universidad de La Habana, Cuba.

Nesse período, obtive financiamento para o desenvolvimento da pesquisa no Brasil, Argentina e Chile por meio da Fapesp (Fundação de Amparo à Pesquisa do Estado de São Paulo), processo número 2011/50055-0, e também pela Capes (Coordenação de Aperfeiçoamento de Pessoal de Nível Superior) para o doutorado-sanduíche em Cuba.

Para tanto, contei com o suporte de diversos profissionais para a execução da presente obra no Brasil e no exterior, dos quais menciono: Nelba Azevedo Penna, Leila Christina Duarte Dias, Eduardo San Marful Orbis, Cristian Henríquez Ruiz, Federico Arenas Vásquez, María Laura Silveira, Perla Zusman, entre tantos outros, bem como suporte familiar na figura de minha mãe Tereza Jurado e de Daniela nessa nova etapa da minha vida. 
Nessa nova trajetória de minha vida profissional agradeço à Universidade Estadual de Mato Grosso do Sul (Uems) por ter me acolhido tão bem. Sou grato aos alunos que tenho, aos meus orientandos, amigos e colegas de trabalho que me estimulam diariamente a produzir ciência e a divulgá-la nos mais variados locais.

Por fim, é importante frisar que o livro está organizado em seis partes que versam sobre o tema das telecomunicações de diferentes formas. Nos itens 1 e 2 a abordagem é a teórica e epistemológica, no tópico 3 o conteúdo é de caráter histórico e nos demais é apresentada a Geografia das Telecomunicações, em sentido prático e concreto. Aos que se propuserem a compreender tal obra, faço votos de boa leitura! 


\section{SUMÁRIO}

Prefácio 9

Introdução 13

1 A geografia e as telecomunicações 41

2 As telecomunicações no uso do território 87

3 Os atuais usos corporativos do território pelas empresas de telecomunicações no brasil 127

4 Expressão geográfica do uso corporativo do território pelas empresas de telecomunicação 213

Conclusão 273

Referências 283 


\section{Prefácio}

Para realizar este prefácio, inicio pela exposição de como se pode entender esse substantivo. De maneira resumida, um prefácio tem o intuito de apresentar, sucintamente, uma obra escrita por outra pessoa, tecendo comentários sobre sua estrutura e seu conteúdo (destacando a temática), bem como sobre seu autor. É isso que faço a seguir.

Vou iniciar pelo fim do parágrafo anterior. O autor, Paulo Fernando Jurado da Silva, foi meu orientando nos níveis de iniciação científica, mestrado e doutorado. Acompanhei, portanto, toda a sua formação, desde a graduação até o doutorado. No início, ele trabalhou com a indústria nas cidades pequenas da região; o tema foi aprofundado em sua dissertação de mestrado, a qual inspirou um livro que publicamos juntos sobre o conceito de cidade pequena. No doutorado, ele mudou completamente seu foco, passando ao estudo das telecomunicações no Brasil. O percurso do autor pode ser visto em termos de abrangência regional e temática, saindo das cidades pequenas no oeste do Estado de São Paulo para um tema de escopo nacional. Seu diálogo, no doutorado, foi enriquecido por estágios de pesquisa realizados na Argentina e no Chile. Assim, o crescimento do autor fica evidente pela qualidade de seu trabalho e por sua persistência e disciplina para o trabalho intelectual. Por 
essas razões, o texto que ora se apresenta ao público tem as qualidades que passo a destacar.

$\mathrm{Na}$ introdução, fica clara sua interlocução com o desenvolvimento das técnicas porque sua leitura do Brasil, feita por meio das telecomunicações, articula a telefonia celular, a internet e a televisão no âmbito das principais empresas, levando a uma interpretação que pode se circunscrever na Geografia Econômica. Mas ele não para aí porque, no final, depois de mostrar que a estrutura das telecomunicações no Brasil conforma um Psi, mesmo que a sua leitura espacial seja ampla, a dinâmica e o processo que foram descritos carregam suas contradições, desigualdades, sínteses e assimetrias. Ao levantar a ideia de um manifesto pela democratização do acesso à informação, o autor analisa a monopolização do setor, mostrando que a ação das empresas se faz por justaposição e sobreposição no território. Para o futuro que já está no presente será preciso respeitar a solidariedade territorial e a justiça nas possibilidades de comunicação porque é preciso pensar a cidadania exercida por todos e não apenas por um grupo de empresas controladoras de (em suas palavras) "recursos, inovação, comunicação e produção territorial da informação e da desinformação". Ele mostra, assim, que um trabalho científico não deve se bastar a si mesmo, mas carregar algo que possa ajudar nas transformações da sociedade, visando à democratização do uso dos avanços tecnológicos.

Para chegar a essa conclusão, o autor mostrou, inicialmente, o seu encaminhamento metodológico. Ressalto essa parte do trabalho porque é importante, a todos os geógrafos, deixar claro como procedeu, onde recolheu a informação geográfica e por quais dados, como cartografou e como analisou o tema por diferentes ângulos.

A partir de seu encaminhamento metodológico, ele chega à sua proposta de uma Geografia das Telecomunicações, focando-as como problema geográfico a estudar e sua contribuição ao desenvolvimento desigual. Seu diálogo é com diferentes autores, de áreas distintas, com textos atuais e textos clássicos, do Brasil e do exterior, quando procura reter os principais elementos que sustentam 
sua análise, não negligenciando a evolução das técnicas e da tecnologia como características da globalização.

Destaco sua contribuição ao uso do território pelas telecomunicações, mostrando a evolução das infraestruturas no processo de integração territorial do Brasil, desde o século XIX e início do século $\mathrm{XX}$, quando as grandes multinacionais do setor passam a operar no Brasil com seus escritórios próprios. Em termos de doutrina, o país passa do liberalismo até a primeira guerra mundial, pelo período em que o Estado brasileiro detém o monopólio das telecomunicações até as décadas mais recentes, caracterizadas pela concessão geral do setor à iniciativa privada, em um processo de privatização das companhias estatais.

A capacidade de síntese de Paulo Jurado é notória porque seus quadros e mapas espelham aquilo que ele expõe ao longo do texto. Mesmo que todas as ilustrações sejam em preto e branco, a qualidade da representação resume as ideias expostas e deixa, ao leitor, a clara expressão da história e das dinâmicas das empresas de telecomunicações no Brasil. Para chegar a algumas ideias conclusivas, ele descreve, com detalhes, aspectos técnicos do sistema de televisão, mapeando a distribuição dos assinantes da TV paga no Brasil segundo o grau da tecnologia empregada, o desenho estrutural da internet e as principais detentoras do uso das tecnologias mais avançadas; e chega a mostrar como foi feito o loteamento do espaço brasileiro para as grandes empresas, o que leva à expressão geográfica do uso corporativo do território e sua normatização. Ao apontar como se compõe o Psi da estrutura das telecomunicações no Brasil, o autor mostra que há alianças corporativas constituídas em termos globais, nacionais e locais, o que provoca uma guerra competitiva entre partes do território quando é necessário instalar objetos de uma ou outra companhia em um ou outro ponto.

O livro, assim, é resultado da dedicação do autor à sua tese de doutorado, de suas viagens para Argentina e Chile a fim de obter dados e debater ideias com outros autores, do aproveitamento de sua vivência intensa no GAsPERR (Grupo de Pesquisa Produção do Espaço e Redefinições Regionais), enfim, de sua participação 
efetiva na vida universitária. Por essas razões, o autor tem muito a dizer e tenho certeza de que a leitura deste livro contribuirá para quem se interessa pela Geografia Econômica, pelo estudo das telecomunicações ou pelos recortes territoriais da Geografia do Brasil; em outras palavras, para o avanço do conhecimento geográfico.

Presidente Prudente, setembro de 2015. Eliseu Savério Sposito 


\section{INTRODUÇÃO}

A temática das telecomunicações já foi pesquisada por diferentes autores brasileiros da Geografia e de áreas afins, a exemplo da Sociologia e da Economia. Basicamente, é um tema que foi inaugurado com maior ênfase nas Ciências Humanas, no século XX, ao acompanhar as transformações e avanços mundiais da comunicação, da informação e da engenharia, além da exploração do espaço sideral, com o lançamento de satélites e instalação de outros objetos técnicos.

No Brasil e no mundo, o conjunto de obras relacionadas ao estudo das telecomunicações demonstrou-se por meio do levantamento e revisão bibliográfica abrangente, com diversos enfoques teóricos, metodológicos e doutrinários. As construções teóricas têm, portanto, se colocado de modo heterogêneo.

Além disso, cabe fazer uma ressalva ao leitor de que esse livro não tem por objetivo estocar referências a respeito do assunto e muito menos esgotar o universo teórico e polissêmico da temática. Ao longo do texto, no entanto, serão expostas de diferentes maneiras algumas das abordagens estudadas e que fizeram parte do trabalho de revisão da presente obra. Isso não significa, por outro lado, que todas serão utilizadas a posteriori na construção teórica, mas que serviram de base para pensar e refletir sobre o tema, mesmo que de maneira introdutória. 
É preciso também ilustrar que o conjunto de autores mencionados se concentra na Geografia, embora haja, em distintos momentos, o uso de teóricos oriundos dos demais campos da ciência. Outro ponto importante a ser frisado é que nessa tarefa não haverá uma linearidade, em termos temporais de citação de textos e obras, mas uma concatenação teórica de acordo com a temática e a pertinência do debate.

Hoje não é possível debater a sociedade sem mencionar o papel da informação e das telecomunicações, sejam nas relações de trabalho, negócios, vida cotidiana, política, ambiente ou mesmo na organização territorial e na produção de novas infraestruturas técnicas. Seu significado extrapola o simples fato de levar a comunicação a distintas partes do mundo para assumir a posição de base de sustentação da sociedade capitalista e a formação de uma "sociedade da informação" (Castells, 2003).

Formas cada vez mais globalizadas das técnicas são difundidas a todo o momento, definindo, por outro lado, o conjunto de transformações e desigualdades socioespaciais que cada lugar, por meio das relações sociais estabelecidas entre múltiplos agentes, acolhe e sintetiza de forma contraditória. Com isso, se produz uma Geografia das Telecomunicações ${ }^{1}$, alicerçada, particularmente, pelo papel que assume a informação na produção territorial, lembrando que: "[...] A técnica nos ajuda a historicizar, isto é, a considerar o espaço como fenômeno histórico a geografizar, isto é, a produzir uma Geografia como ciência histórica." (Santos, 2008, p.49).

A informação, nessa perspectiva, ganha forte expressividade nos estudos voltados à compreensão da sociedade, cabendo, dentre as diferentes possibilidades de análise territorial, demarcar as relações

1 A Geografia das Telecomunicações tem sido explorada com este nome em diversos países, a exemplo do trabalho desenvolvido por Andrew E. Gillespie (1988) e observada de diferentes maneiras em Kellerman (1993), bem como em Graham e Marvin (1996). Nessa obra apoiamo-nos especialmente em Gillespie (1988) ao afirmar que: "[...] the 'geography of telecommunications' needs to be afforded a much higher status within economic geography [...]” (p.61). 
de poder, estratégias e conflitos estabelecidos com fundamento corporativo ou banal no seu uso.

Contel (2011), a esse respeito, ajudou a elucidar o caminho de incorporação da categoria informação pela Geografia. Para esse autor, o processo de internalização dessa expressão se deu junto à escola sueca de Geografia Econômica, que possuiu como um de seus principais expoentes Torsten Hägerstrand, que: “[...] trabalhou fundamentalmente com dois temas em seus estudos: o de 'difusão espacial das inovações' e do tema da 'mobilidade' (com destaque para a análise das migrações) [...]” (Contel, 2011, p.71).

Ainda para Contel (2011, p.72), é na teoria da "difusão espacial das inovações" que se encontra maior proximidade conceitual com a temática da informação e, portanto, "[...] a classificação dos meios de informação (information media) a partir de seus atributos espaciais se divide em dois principais tipos: informações públicas e privadas".

É claro que seguindo a trilha proposta por esse mesmo autor, de assimilação da categoria informação pela Geografia, os comentários não se encerram na citação de Hägerstrand. $\mathrm{O}$ autor amplia sua base teórica, mencionando Gunnar Törnqvist, que foi professor da Universidade de Lund e participou da escola de Geografia Sueca, bem como Alcan Pred, da Universidade da Califórnia (Berkeley), que por diversas vezes colaborou com a construção de debates em Lund e, portanto, sua contribuição:

[...] teve influência (mais ou menos decisiva) em importantes intelectuais da passagem do século XX para o século XXI, como são Anthony Giddens ([1984] 1989), Milton Santos (1996) e Paul Krugman (1993; 1997) [...]. (Contel, 2011, p.79)

Com isso, a postura defendida neste livro é que, tratadas como um tema geográfico, as telecomunicações constituem importante área para a compreensão de como a informação se difunde pelo território. Assim, na reflexão sobre o assunto é possível verificar a formação de redes técnicas, uso corporativo do território, a discussão do poder e das normas, entre outras dinâmicas que se somam 
contemporaneamente ao estudo da técnica, da inovação e das tecnologias da informação.

Por outro lado, é preciso ter em mente que a interpretação ${ }^{2}$ das telecomunicações pode ser útil para a compreensão e apreensão das desigualdades e transformações socioespaciais recentes, em que se inserem o mundo e a sociedade como totalidades. Dessa maneira, é impossível negar o papel da informação e das telecomunicações na organização do território, em distintas partes do mundo. No Brasil, essa afirmação tem ganhado cada vez mais importância ao verificar as transformações socioespaciais (Jurado da Silva, 2011) que o país vem passando nos últimos anos, com a ampliação da densidade técnica, científica e informacional em diversas regiões.

Nesse contexto, mediante esse conjunto de transformações, se passa a escrever e criar terminologias como "sociedade em rede", "meio técnico-científico-informacional", entre outras expressões ${ }^{3}$ que se somam constantemente, na tentativa de caracterizar as mudanças colocadas em curso por meio da Terceira Revolução Industrial e do papel que a informação assume especialmente a partir da década de 1970, como escreveram, em diferentes contextos teóricos, autores como Dematteis (1986), Hepworth (1990), Morgan (1992), Lojkine (1995), Castells (1999), Moreira (2000), Santos (2008), entre outros. Algumas dessas ideias defendidas por esses autores são usadas para nomear o momento atual e apresentadas sinteticamente no Quadro 1.

2 A palavra "interpretação" tem o sentido de julgar e dar sentido ao fato a ser estudado, o que difere, por exemplo, de "analisar" que tem o significado de examinar e avaliar. Uma expressão não anula a outra e quase que invariavelmente se tornam um par indissociável para a compreensão geográfica proposta.

$3 \mathrm{Na}$ maioria dos casos, tais expressões são apenas noções. Isso porque tem uso fluido e são utilizadas pelo Estado, mídia e senso comum. A ideia de noção é, portanto, diferente do termo "conceito", que tem uso atrelado à ciência e inserido no corpo de uma teoria (Sposito, 2004; Jurado da Silva, 2011). Já a expressão da categoria é associada a uma ideia que se constitui em objeto de conhecimento para a ciência. 
Quadro 1 - Expressões utilizadas para compreensão da sociedade atual.

\begin{tabular}{|c|c|}
\hline Expressões & Autores \\
\hline Território informatizado & Dematteis (1986) \\
\hline Aldeia global & McLuhan (1989) \\
\hline Era das telecomunicações & Morgan (1992) \\
\hline Sociedade da informática & Schaff (1995) \\
\hline Meio técnico-científico-informacional & Milton Santos (1996) \\
\hline Mercado informacional & Dertouzos (1997) \\
\hline Era da Informação & Castells (1999) \\
\hline Era tecnológica & Pinto (2005) \\
\hline
\end{tabular}

Fonte: Baseado na leitura dos autores citados. Organização: Jurado da Silva (2014).

Expressões como "aldeia global" e "era da informação" ganham constante difusão e se somam a outros termos que são criados, frequentemente, na tentativa de sintetizar o processo de integração da sociedade no movimento informacional, desencadeado pelo avanço das telecomunicações. Sobre o assunto, Zook et al. (2004) já havia considerado que tanto no meio acadêmico quanto popular essas terminologias se multiplicam e:

In both popular and academic discussions of digital communication technologies and their possible socioeconomic implications, a large panoply of metaphors has been coined with a premise on geographic place, such as superhighways, teleports, server farms, homepages, and so on (Adams 1997).

Likewise, the transactions and data exchanges at the heart of the so-called Network Society (Castells 1996), are also frequently imagined and envisioned in terms of "spaces" - hyperspace, dataspace, netspace and, of course, cyberspace (Dodge and Kitchin 2001; Thrift 1996). The result, according to Graham (1998), is digital geographies that are made tangible and knowable through familiar territorial analogy. (Zook et al., 2004, p.158)4

4 Todas as citações serão mantidas na língua original dos autores para manter fidelidade à obra. 
Nesse sentido, a ideia do ciberespaço (uma das primeiras a serem criadas para explicar a formação de um espaço cibernético, virtual) já comparecia em um romance datado de 1984, escrito por William Gibson, intitulado "Neuromancer". Nesta obra, são descritos conflitos de interesse de empresas globais, redes digitais e um novo contexto cultural. Foi só em momento posterior, no entanto, que autores do meio acadêmico passaram a utilizar tal termo, a exemplo de Lévy (1999, p.85), que o definia:

[...] como espaço de comunicação aberto pela intercomunicação mundial dos computadores. Esta definição inclui o conjunto dos sistemas de comunicação eletrônicos (aí incluídos o conjunto de redes hertzianas e de telefonia clássica) na medida em que transmitem informações provenientes de fontes digitais ou destinadas à digitalização [...].

Nesses termos, é preciso ressaltar que o discurso do ciberespaço foi incorporado de modo muito evidente pela mídia e também passou a fazer parte do cotidiano das pessoas comuns. No ciberespaço, há o aparecimento de intenções entre diferentes sujeitos em um ambiente virtual, na interface homem versus máquina.

Ações banais como retirar um extrato bancário são também formas presentes do modo cada vez mais digital de diferentes objetos técnicos. Outras atividades, como ouvir música, desenhar, namorar, comprar, jogar, trabalhar, podem ser feitas, agora, a partir desse contexto. Nesse quadro, poderia se atribuir ao período atual diversos sentidos e significados. Esse debate é intenso na academia e não há consenso (pelo menos por enquanto) sobre as transformações que vivenciamos na "era da informação".

Para Gates (1995), por exemplo, a sociedade está apenas no início de sua revolução mais profunda e, com isso:

[...] vai durar muitas décadas até receber impulso de novas "aplicações” - novas ferramentas às necessidades por enquanto ainda imprevistas. Nos próximos anos, governos, empresas e indivíduos 
terão de tomar decisões que influenciarão na forma que a estrada da informação vai se expandir e na quantidade de benefícios a serem auferidos. (Gates, 1995, p.8)

Revolução essa que se desenvolve a partir das redes técnicas anteriores, fundamentadas no uso do telégrafo, rádio, telefone e televisão, mas que é inovada por circuitos técnicos e pela evolução da robótica, das telecomunicações, da química e de outros segmentos de ponta. Assim, velho e novo se combinam na produção dessa síntese de múltiplas relações, no "desenvolvimento desigual e combinado" (Trotsky, 1967) da sociedade, da técnica e do espaço.

Tal revolução tem-se assentado, sobretudo, em inovações no campo da microeletrônica como as verificadas em processadores, transistores, telecomunicações (satélites e fibras ópticas) e na área de informática. Porém, pode-se comentar que foi a invenção do microprocessador, em 1971, que potencializou enormemente o uso de computadores, agregando a esses a chamada estrutura de chips embutidos (Bresciani, 2007) e, por conseguinte:

Paralelamente ao desenvolvimento da eletrônica e dos computadores, as transformações das telecomunicações foram outro fator preponderante para o estabelecimento do ciberespaço como ele se dá atualmente. Muitos apontam como o grande salto das telecomunicações, o início da corrida espacial com o lançamento na órbita da terra dos satélites, abrindo caminho para as comunicações intercontinentais. (Bresciani, 2007, p.23)

A sociedade caminha na expressão de um "modo informacional de desenvolvimento", a que se referiu Castells (1992), e pode ser compreendido pelas: "[...] historical interactions with the process of restructuring of the capitalist mode of the production [...]." (Castells, 1992, p.7). Igualmente, torna-se coerente afirmar que, apesar de esse debate ocorrer e ser dinâmico, a sociedade, atualmente, se manifesta em rede. 
Ademais, admite-se que ampla parcela da sociedade não tem acesso às condições de vida digna e sequer à informação de qualidade. Assim, enquanto determinada quantidade da população usufrui dos modos cada vez mais estandardizados de consumo, outra parte da sociedade não a utiliza e não tem condições financeiras para tal. Além disso, muitas vezes a expressão da cidadania é confundida como acesso ao consumo e às novas formas de endividamento das pessoas.

Cidadania e consumo, nesse movimento, passam bem longe da parcela mais pobre da população que é invisível a determinados governantes, na execução de políticas públicas e na formação de uma consciência universal, mais justa e fraterna. Há, portanto, uma ilusão de que há democracia ampla no mundo, de que há liberdade de escolha e de consumo, quando na realidade não há. Nessa perspectiva, a grande mídia, os governos e o mundo corporativo acabam vendendo a imagem de que não há fronteiras para se viver em um cenário cheio de oportunidades, bastando "querer" e ter "força de vontade" para superar os obstáculos e ascender socialmente, quando o que há é uma luta entre ricos e pobres em curso, marcada pelas diferentes formas de alienação, vigilância e controle de recursos, pessoas e de território.

Ademais, torna-se relevante para a compreensão desse quadro de contradições a adoção da expressão geográfica do "território usado", concordando com Milton Santos quando escreveu que: "O que interessa discutir é, então, o território usado, sinônimo do espaço geográfico. E essa categoria, território usado aponta para a necessidade de um esforço destinado a analisar sistematicamente a constituição do território [...]" (Santos, 2001, p.20). Não são, deste modo, forças solidárias que constroem o território e o usam pacificamente, mas um conjunto de agentes, instituições e companhias que alimentam uma guerra competitiva pelo poder e pela normatização territorial. Além disso, ainda que o território usado seja considerado sinônimo de espaço geográfico (Santos, 2001), é preciso levar em conta que: 
O território não é apenas o resultado da superposição de um conjunto de sistemas naturais e um conjunto de sistemas de coisas criadas pelo homem. O território é o chão e mais a população, isto é, uma identidade, o fato e o sentimento de pertencer àquilo que nos pertence. O território é a base do trabalho, da residência, das trocas materiais, espirituais e da vida, sobre os quais ele influi. Quando se fala em território deve-se, pois, de logo, entender que se está falando em território usado, utilizado por uma dada população. (Santos, 2001, p.97, grifo nosso)

Nesse panorama é que se insere o problema de pesquisa da obra ao relacionar o estudo das telecomunicações no Brasil, no esforço de compreender geograficamente três pilares de sustentação da sociedade informacional que estão ligados não somente às atividades banais, a saber: a telefonia celular, a internet e a televisão por assinatura no uso do território.

Em uma concepção mais ampla, os meios de transporte e a comunicação eficaz favoreceriam a produção industrial, os serviços, o comércio e agricultura, ao passo que as telecomunicações seriam caracterizadas como suporte técnico e uma condição espacial da técnica para propiciar o desenvolvimento econômico e a reprodução do capital, em larga escala.

Milton Santos (2001) considerou que, no final do século XX, a informação dirigiu o sistema de técnicas existentes, possibilitando uma presença planetária de seu conteúdo. O aprimoramento das técnicas é também o desenvolvimento da humanidade. Consequentemente, a técnica da informação vai propiciar a aceleração do processo histórico em seu sentido contemporâneo, assegurando a presença de objetos técnicos em escala planetária e, nessa perspectiva: "Na história da humanidade é a primeira vez que tal conjunto de técnicas envolve o planeta como um todo e faz sentir instantaneamente sua presença [...]" (Santos, 2001, p.25).

Nessa interpretação, o meio geográfico é definido a partir da inserção da técnica, da ciência e da informação. A informação pode 
ser vista, então, como um recurso e sua distribuição pelo território usado é desigual e, portanto:

Por meio dos satélites, passamos a conhecer todos os lugares e observar outros astros. $\mathrm{O}$ funcionamento do sistema solar torna-se mais perceptível, enquanto a Terra é vista em detalhe; pelo fato de que os satélites repetem as suas órbitas, podemos captar momentos sucessivos, isto é, não mais apenas retratos momentâneos e fotografias isoladas do planeta [...]. (Santos, 2001, p.32)

Os satélites organizam parte do circuito informacional em escala global e também nacionalmente, e são a expressão da técnica, sobretudo, vislumbrada na corrida espacial, travada durante a Guerra Fria, no século XX. Sobre o assunto, Castillo Argañarás (2008) contribuiu para a fundamentação histórica dessa discussão quando escreveu que:

En ese principio solamente los Estados Unidos de América y la entonces Unión Soviética pertenecían al exclusivo "club" de Estados que tenían acceso al espacio exterior; luego se amplió el espectro y aparecieron las primeras organizaciones internacionales: INTELSAT, INMARSAT y la Agencia Espacial Europea entre otras. No obstante algunas de estas organizaciones internacionales sufrieron un embate privatizador de la década de los noventa transformándose en personas jurídicas privadas, como por ejemplo INTELSAT e INMARSAT. (Argañarás, 2008, p.13)

Neste cenário, é por meio da exploração de satélites que transmissões internacionais de televisão são postas em curso, levando ao mundo, por exemplo, grandes eventos esportivos e políticos, ano após ano, tal como acontece com a Copa do Mundo e as Olímpiadas. Assim, não é o Estado o provedor dos recursos de tecnologia e exploração de satélites, mas as empresas de caráter privado que dominam esse mercado. 
O Quadro 2 ilustra essa argumentação ao expor a listagem por direito de exploração de satélites, no território nacional. Há três operadoras de satélites, sendo que a Hispamar, responsável pelo Amazonas 1 e 2, foi criada por meio da parceria da companhia Hispasat com a Oi; a Telesat, operadora do satélite Estrela do Sul 4, tem sede em Ottawa, Canadá; e, por fim, a Star One, de propriedade da Embratel.

Quadro 2 - Empresas detentoras de direito de exploração de satélites no Brasil.

\begin{tabular}{|c|c|c|c|c|}
\hline $\begin{array}{l}\text { Operador } \\
\text { do satélite }\end{array}$ & Satélite & Banda & $\begin{array}{c}\text { Posição } \\
\text { orbital }\end{array}$ & Em operação \\
\hline \multirow{2}{*}{ Hispamar } & Amazonas-1 & \multirow{2}{*}{$\begin{array}{c}\mathrm{C}, \mathrm{Ku} \text { e } \\
\mathrm{Ka}\end{array}$} & \multirow[t]{2}{*}{$61,0^{\circ} \mathrm{W}$} & \multirow[t]{2}{*}{ Sim } \\
\hline & Amazonas-2 & & & \\
\hline Telesat & Estrela do Sul 2 & $\mathrm{Ku}$ & $63,0^{\circ} \mathrm{W}$ & Sim \\
\hline \multirow[t]{8}{*}{ Star One } & Brasilsat-B2 & $\mathrm{C}$ & $92,0^{\circ} \mathrm{W}$ & Sim \\
\hline & Brasilsat-B3 & $\mathrm{C}$ & $75,0^{\circ} \mathrm{W}$ & Sim \\
\hline & Brasilsat-B4 & C & $84,0^{\circ} \mathrm{W}$ & Sim \\
\hline & Star One-C1 & $\mathrm{C}, \mathrm{X}, \mathrm{Ku}$ & $65,0^{\circ} \mathrm{W}$ & Sim \\
\hline & Star One-C2 & C, X, Ku & $70^{\circ} \mathrm{W}$ & Sim \\
\hline & Star One -C3 & $\mathrm{CeKu}$ & $75,0^{\circ} \mathrm{W}$ & Não \\
\hline & Star One -C4 & $\mathrm{C}, \mathrm{L}, \mathrm{S}$ & $75,0^{\circ} \mathrm{W}$ & Não \\
\hline & SStar One-C5 & $\mathrm{Ce} \mathrm{Ku}$ & $68,0^{\circ} \mathrm{W}$ & Não \\
\hline
\end{tabular}

Fonte: Extraído de Teleco. Disponível em <www.teleco.com.br/sat_rel.asp>. Acesso em: 21 set. 2015. Reconfigurado por Jurado da Silva (2012).

As telecomunicações são, nesse universo, um elemento ativo da reprodução do capital, possibilitando maior flexibilidade no processo produtivo, cisão territorial da produção e gestão, ampliação dos fluxos comerciais em múltiplos circuitos de interação espacial e maior competitividade interempresarial por inovações.

Mas esse processo não é homogêneo e as estruturas físicas que dão sustentação às telecomunicações podem representar, em última instância, relações de poder e hierarquia, ao passo que são controladas, quase que invariavelmente, por grandes empresas com atuação global ou mesmo regional. Estas, por sua vez, exercem 
o monopólio de sua comercialização, distribuição e reprodução em frações variadas do globo terrestre e para além da atmosfera com os satélites. Além disso, configuram, em outro sentido, redes globais eletrônicas potentes, elevando o ritmo de complexidade da divisão territorial do trabalho, fortalecida pela ação dos serviços de telecomunicação.

Raffestin $(1993 \text { [1980]) })^{5}$, nesse sentido, será um autor utilizado mais adiante sobretudo para referenciar a questão do poder e do controle das empresas, que se soma no entendimento do uso corporativo do território de diferentes formas, em outros contextos, como fizeram de forma variada Bobbio (1992), Foucault (2001 [1979]) e Gramsci (1976). Lembrando que tais autores debateram a questão do Estado e que aqui será elucidada, particularmente, a partir de sua ação reguladora no mercado, tendo em vista os segmentos eleitos para a análise investigativa.

Assim, tais segmentos (telefonia celular, televisão paga e internet) foram escolhidos em razão da expressividade e da interatividade que gozam no período atual da técnica, bem como pelo número crescente de novos consumidores que apresentam, ano após ano. Diversas investigações e fontes (dentre elas a Pesquisa Nacional por Amostra de Domicílios, de 2011, do Instituto Brasileiro de Geografia e Estatística - IBGE) atestam, em termos estatísticos para essa realidade. Não é mais a telefonia fixa que direciona a liderança nos acessos e linhas ativas da população e nos serviços de telecomunicação. "[...] Em suma, a telefonia fixa não está crescendo no Brasil e não se trata de uma simples inflexão, mas uma tendência de quase uma década." (Cavalcante, 2011). ${ }^{6}$ Assim, apesar de a telefonia fixa ter sido a evolução primordial que propiciou o surgimento da telefonia celular, esta muitas vezes não é vista como um dado de cidadania, de residência fixa, em grande parte das políticas públicas.

5 A obra de Raffestin foi publicada originalmente em 1980. Daqui em diante a mesma obra será citada a partir do ano correspondente à edição consultada.

6 Artigo não paginado. 
Além disso, é válido frisar que os segmentos eleitos para a investigação são pagos e podem ser mensurados pelo número de consumidores das operadoras privadas. Os mesmos, em alguns casos, são comercializados em conjunto por estas, diferentemente do rádio e da televisão aberta, o que justifica a eleição destes, bem como a originalidade de trabalhá-los em conjunto. Estes, por sua vez, representam, atualmente, os novos meios de penetração da técnica na vida cotidiana das pessoas, bem como no ambiente de negócios das empresas no Brasil.

Hoje, é a telefonia celular que move o tráfego nacional de informação, aliada à convergência da internet, bem como em outro patamar pelo crescimento da televisão e suas modalidades de difusão da informação, como mostra o Gráfico 1. Com isso, analisando tal ilustração que trata de apresentar a penetração dos serviços de comunicação no Brasil, por domicílio, com base nos dados disponibilizados pelo IBGE e extraído do Ministério das Comunicações, é possível inferir ainda um quadro bastante desigual para o setor.

A televisão é o veículo com maior penetração, alcançando 97\% dos domicílios brasileiros em 2012, seguido pelos domicílios com telefone (91\%) e rádio (81\%). É preciso atentar, no entanto, para o fato de que a telefonia fixa representava $3 \%$ desse total e a telefonia celular 51\%. Ou seja, a telefonia fixa desde 2003 vem apresentando um forte declínio em termos de penetração nos lares brasileiros, sendo esse espaço cada vez mais preenchido pela telefonia celular. A universalização dos serviços nesse contexto é, então, trazida para outro patamar e meta.

Por outro lado, isso não significa afirmar que não haverá atenção analítica à telefonia fixa, bem como às fibras ópticas e satélites que dão suporte à arquitetura da informação, e tais objetos serão mencionados e trabalhados em diferentes momentos - embora esse não seja o foco prioritário da pesquisa e por já terem sido alvos exaustivos de diversos trabalhos científicos.

Com a utilização desses objetos técnicos (telefonia celular, internet e televisão por assinatura), mesmo que se tenham diferentes regiões com fusos horários distintos, a transmissão da informação 
poderá ser feita de maneira instantânea, ainda que se reconheça que não são consumidos por ampla parcela da população. Desse modo, o problema de pesquisa se relaciona, consequentemente, à pergunta geral que orientará a investigação, ou seja: como se configura atualmente o uso corporativo do território pelas empresas privadas de telecomunicação no Brasil?

Ademais, compreender o uso corporativo do território pelas empresas de telecomunicação é, antes de tudo, um trabalho relacionado ao estudo da técnica e da tecnologia. Isso porque é importante reconhecer esse par (técnica/tecnologia) filosófico e histórico na construção da sociedade atual como condição sine qua non para o desenvolvimento do capitalismo e da globalização, ancorado na comunicação, no setor financeiro e no valor da informação na economia.

Trabalhando o assunto pela variável da técnica e da Geografia é possível afirmar que os sistemas de telecomunicação envolvem, grosso modo, o deslocamento e a troca de matéria e energia, em termos socioespaciais. Nesse universo, cada local tenderá a acolher de modo particular conteúdos da técnica, informação, ciência, comunicação e daí assinalar como fez Milton Santos, que:

Em cada fração da superfície da terra, o caminho que vai de uma situação a outra se dá de maneira particular; e a partir do "natural" e do "artificial" também varia, assim como muda as modalidades do seu arranjo. (Santos, 2008, p.233)

Com esse intuito, procurar-se-á responder a tal indagação pela perspectiva da Geografia Econômica, com a análise das principais estratégias das empresas de telecomunicações (nos respectivos segmentos selecionados para a investigação) e no contexto do Pensamento Geográfico por meio da interpretação e diálogo crítico com ideias vinculadas especialmente ao estudo da informação; como as propostas por Milton Santos, que contribuiu com o conceito de meio técnico-científico-informacional, em diversos contextos. Além disso, é importante destacar que a relação de interface, como 
comparece no título da obra, entre distintos campos do conhecimento deve ser entendida como uma atividade imprescindível para a construção do conhecimento, na tentativa de colaborar para a epistemologia do uso corporativo do território pelas empresas de telecomunicações.

Essa postura teórica representa, por sua vez, movimento e comparece à construção da obra. Ou seja, revela parte da contribuição final da pesquisa a que pretende esse trabalho, na tentativa de produzir elementos que favoreçam uma interpretação das telecomunicações no Brasil, de modo a representar teoricamente o assunto por meio da normatização do território, uso corporativo e da expressão geográfica produzida daí decorrente; como será mais bem detalhado adiante.

Para ser mais claro: é a maneira como o autor concebe a ideia de que as telecomunicações representam uma espacialidade a ser examinada pela óptica da Economia e da Geografia Econômica, mas sem descolar dessa interpretação a teoria inserida na Geografia, Epistemologia e na Filosofia das Técnicas dessa expressão. Ideia essa que também é apoiada em estudos de Eliseu Savério Sposito, que já elaborou, em outros contextos, obras relacionadas ao estudo da Filosofia ${ }^{7}$ e da Geografia, como contribuição para o ensino do Pensamento Geográfico (Sposito, 2004), e em Santos (2008, p.49) quando defendeu que, nessa perspectiva: “[...] a Geografia deve, ao menos, ser vista como um estudo de caso para as filosofias da técnica senão propriamente como uma contribuição empírica para a produção de uma filosofia das técnicas [...]” (Santos, 2008, p.49).

Além disso, é preciso exercitar a crítica diante dessa postura, tendo em mente que: "A teoria geográfica tem de ser buscada no

7 Para Santos (1988, p.11) "Sem dúvida a palavra filosofia assusta, de um lado porque ela é, numa acepção pejorativa, frequentemente confundida com a metafísica: entre os que se dizem preocupar com o concreto das coisas, muitos imaginam que o esforço de abstração pode ser feito fora do concreto e mesmo contra o concreto. E a concretude da abstração está na base mesma da realização dos nossos mínimos atos como ser social. Sem abstração não poderia haver linguagem nem produção [...]”. 
seu domínio próprio: o espaço. A filosofia pode ser um guia, mas os filósofos não nos oferecem respostas a priori [...]" (Santos, 1988, p.11, grifo do autor).

Ainda para Santos (2008, p.49) a resolução do problema epistemológico da Geografia, no âmbito da Filosofia das Técnicas, deveria passar pela visão integrada e sistematizada da análise entre espaço e tempo, bem como da técnica. Interpreta-se, com base na argumentação desse autor, que a Geografia deveria fornecer os elementos necessários do ponto de vista conceitual para superação de estudos que isolam o espaço do tempo, negligenciando, sobretudo, o papel da técnica na transformação dos lugares ao longo da história e, por conseguinte: “[...] As técnicas, de um lado, dão-nos a possibilidade de empiricização do tempo e, de outro lado, a possibilidade de uma qualificação precisa da materialidade sobre a qual as sociedades humanas trabalham [...]" (Santos, 2008, p.55).

Já em outro texto produzido por Santos (1988, p.5), tal autor irá detalhar que antes da Geografia institucionalizada e acadêmica existia uma Geografia feita por filósofos, a exemplo de Estrabão, explicando o momento de ruptura desse elo (Filosofia-Geografia) ao escrever que:

Desde, porém, que a natureza é uma natureza humanizada, a explicação não é física, mas social. A geografia deixa de ser uma parte da física, uma filosofia da natureza, para ser uma filosofia das técnicas. As técnicas são aqui consideradas como o conjunto de meios de toda espécie de que o homem dispõe, em um dado momento, e dentro de uma organização social, econômica e política, para modificar a natureza, seja a natureza virgem, seja a natureza já alterada pelas gerações anteriores. (Santos, 1988, p.10)

Portanto, a questão das técnicas tem papel central na análise espacial, ao longo do tempo, e pode servir como ferramenta para a leitura da relação sociedade-natureza. Cada técnica possui uma história e pode ser datada ao longo do tempo e, portanto, 
A técnica nos ajuda a historicizar, isto é, a considerar o espaço como fenômeno histórico a geografizar, isto é, a produzir uma geografia como ciência histórica. Assim, pode-se também produzir uma epistemologia geográfica de cunho historicista e genético, e não apenas historista e analítico [...]. (Santos, 2008, p.49)

Nesse contexto é que se insere a contribuição da investigação ao propor o estudo da técnica por meio do estudo das telecomunicações no Brasil pela análise conjunta das estratégias das principais empresas no âmbito da telefonia celular, internet e televisão por assinatura ao longo do espaço e do tempo. Nessa interpretação, a hipótese da pesquisa é que as empresas de telecomunicações colaboram para mudanças bastante profundas na sociedade, operando com estratégias semelhantes no uso corporativo do território brasileiro; compartilhando por ora das vezes as mesmas infraestruturas e redes técnicas, compondo uma expressão geográfica particular e complexa, ao mesmo tempo em que competem pelo uso corporativo do território e ampliação do lucro.

Ademais, as estratégias utilizadas pelas empresas podem ser as mais variadas possíveis, sendo que:

We need, therefore, a better understanding of how firms are being organized and reorganized; how internal and external power structures are configured and reconfigured; how business strategies are developed and implemented, as part of the dynamics of the wider industrial systems of which firms are a part; and how each of these dimensions are "territorialized". (Dicken, Malmberg, 2001, p.346)

Na Geografia ${ }^{8}$, os estudos sobre telecomunicações têm sido empreendidos por vários autores que farão parte do subsídio teórico, em distintos momentos. Leila Dias (1995), por exemplo, voltou-se

8 Há, nesse sentido, diversos trabalhos que foram desenvolvidos com essa temática, a exemplo da tese escrita por Zilá Mesquita denominada: "Antenas, Redes e Raízes da Territorialidade”, defendida em 1992, mas que nesta obra não será alvo de maior detalhamento, em razão da perspectiva teórica aqui adotada. 
ao estudo das relações entre a rede urbana e as redes de informação no Brasil; Castillo (1999) dedicou-se ao estudo dos sistemas orbitais no território; Gomes (2003) refletiu sobre a informação e a questão do lugar no Brasil; Toledo Junior (2003) centrou suas preocupações na compreensão do papel das fibras ópticas nas telecomunicações, entre outros pesquisadores que poderiam ser mencionados.

Assim, técnica, ciência e informação, trabalhadas conjuntamente, foram visualizadas no contexto do mercado global por lógicas políticas e econômicas dos diferentes agentes sociais no espaço. Para Santos (2008, p.239), o meio técnico-científico-informacional é a face geográfica da globalização, dando ao meio geográfico aspecto de universal, sendo esse processo não generalizado e total, embora o conteúdo informacional possa ganhar novos conteúdos de forma ampla e acelerada.

Não é menos importante destacar a relevância dos fluxos para a compreensão dessa característica contemporânea e meios de subordinação ao fenômeno da globalização. Consequentemente, fixos e capital constante também nunca deixaram de ser imprescindíveis para a aceleração e expansão desse processo, como é o caso de citar as estações rádio base, que são estações fixas que alimentam o sistema de telefonia celular; fazendo a ligação com a telefonia fixa, bem como a central de comutação e controle.

Além disso, organizadas em redes, empresas globais operam no território em múltiplos locais, possuindo uma "extensão territorial" de atuação e competição ao estabelecer complexos circuitos de interação espacial, econômica, política e social. Nas leis de livre comércio e concorrência, empresas e negócios conduzem essa economia, muitas vezes, mais que os governos, e:

Assim como se fala de produtividade de uma máquina, de uma plantação, de uma empresa, podemos, também, falar de produtividade espacial ou produtividade geográfica, noção que se aplica a um lugar, mas em função de uma determinada atividade ou conjunto de atividades [...]. (Santos, 2008, p.248, grifo do autor) 
Na realidade, é como se as grandes corporações possuíssem e construíssem estratégias específicas globais para a atuação no mercado onde são os governos os responsáveis por adaptar muitas vezes determinadas leis para acolher as normativas das companhias: privatizando, compartilhando ou concedendo serviços, antes considerados como monopólios e estratégicos, para o Estado, à iniciativa privada nacional e internacional.

No Brasil, por exemplo, o processo de desestatização da telefonia ocorreu na década de 1990, trazendo para a discussão geográfica a questão do uso corporativo do território pelas empresas privadas que diversificarão a posteriori suas estratégias, oferecendo outros tipos de serviços em telecomunicação, como é o caso de ressaltar a televisão por assinatura e a internet, em pacotes integrados. Já atualmente são os grandes oligopólios internacionais que dominam esse mercado.

Porém, há de se ter em mente que esse processo foi lento e gradual e que, ao longo do tempo, a construção das telecomunicações no país participou do jogo decisivo de integração nacional, seja com a instalação do telégrafo, ligando diferentes unidades da federação a um comando central político, seja com a televisão e a formação de uma rede nacional de comunicação. Por conseguinte, é importante assinalar que:

[...] Do telégrafo ao telefone e ao telex, do fax e do computador ao satélite, à fibra óptica e à Internet, o desenvolvimento das telecomunicações participou vigorosamente do jogo entre separação material das atividades e unificação organizacional dos comandos. (Santos; Silveira, 2006, p.73)

Com isso, em sentido amplo, por força de lei ${ }^{9}$ e definição, os serviços de telecomunicações poderiam ser entendidos como a: "[...] emissão ou recepção de símbolos, caracteres, sinais, escritos, imagens, sons ou informações de qualquer natureza, por

9 Lei n. 4.117, de 27 de agosto 1962, artigo $4^{\circ}$. 
fio, rádio, eletricidade, meios óticos ou qualquer outro processo eletromagnético" ${ }^{10}$ e que, em compreensão geográfica, expressa, em diferentes contextos, ordens de comando e tirania, mas também de organização territorial e empresarial.

Assim sendo, conforme o Grande Dicionário Houaiss da Língua Portuguesa ${ }^{11}$, a palavra telecomunicação deriva do grego tel(e), que tem por significado "longe" e do latim communicatı̌o, ōnis, que apresenta o sentido de partilhar, tornar comum. Já a informação possui sua fonte e registro no tempo e no espaço, o que implica, por outro lado, a noção de uma emissão e destino, onde esta, por sua vez, poderia ser entendida como "[...] o instrumento que possibilita o conhecimento da realidade do lugar através das formas-conteúdo e dos sentidos estruturados em uma concepção espaço-temporal" (Gertel, 2003, p.111).

Esse processo não é perfeito, sendo acompanhado por relações de poder e hierarquização, no qual também é comum haver distorção, ruído e interferência. Ademais, quanto maior for a distância entre o emissor e o receptor, mais imprescindível torna-se o uso das telecomunicações para que a mensagem seja transmitida de modo eficiente, sendo necessário um conjunto de dispositivos e meios/ objetos técnicos para que ocorra a comunicação da informação.

Em um país de dimensões continentais como o Brasil, isso se faz muito importante para tornar a disseminação de informações mais fluida e, por isso, a relevância de se estudar a telefonia celular, a internet e a televisão por assinatura. Mesmo que somente uma parcela da população tenha acesso a esses, o conjunto da sociedade é influenciado na propaganda de rua, no consumo, enfim, no estabelecimento das relações sociais na vida cotidiana, o que justifica, por outro lado, a realização de estudos mais aprofundados nessa área, posto que "A influência das técnicas sobre o comportamento humano afeta as ma-

10 Disponível em: <www.planalto.gov.br/ccivil_03/leis/L4117Compilada.htm>. Acesso em: 21 set. 2015.

11 Disponível em: <http://houaiss.uol.com.br/busca?palavra=telecomunica\%25C3\%25A7\%25C3\%25A3o>. Acesso em: 21 set. 2015. 
neiras de pensar, sugerindo uma economia de pensamento adaptada à lógica do instrumento [...]”' (Santos, 2008, p.186).

No âmbito da telefonia celular, Sposito e Bernardes (2009) consideraram que o país contava com cento e trinta e nove milhões de aparelhos em uso, e:

[...] a telefonia celular já supera, em muito, os aparelhos de telefonia fixa e também não se encerra no telos desse meio de comunicação, mas, por outro lado, liga-o à flexibilidade advinda da possibilidade de movimento tanto do usuário quanto do objeto técnico, que exerce, por sua vez, a função de possibilitar a telecomunicação ao usuário em qualquer local que ele esteja. Esse processo promove um uso específico e diferenciado do espaço geográfico, tanto por parte de seus usuários como das suas mantenedoras, no caso operadoras de telefonia móvel celular. (Sposito; Bernardes, 2009, p.64)

A telefonia móvel celular figura, com a internet e a televisão por assinatura (sobretudo, aquela em que a transmissão é via satélite), como uma das maiores invenções da história das telecomunicações utilizadas no mundo para fins comerciais. Tais tecnologias podem se combinar e dar origem a novos produtos, como o iPad e o iPhone da Apple (empresa estadunidense do segmento de eletrônicos e informática), entre outros exemplos que poderiam ser mencionados nesse quadro de criação de gadgets (em português dispositivos). Tais produtos têm como fundamento a "obsolescência programada", resultante da produção e consumo em massa de determinadas mercadorias que são superadas em dado momento da história.

Destarte, para que se tenha noção do desafio que se pretende desencadear com a discussão das telecomunicações no país basta observar que:

Segundo os resultados do Censo Demográfico 2010, a população do Brasil alcançou a marca de 190755799 habitantes na data de referência. A série de censos brasileiros mostrou que a população experimentou sucessivos aumentos em seu contingente, tendo 
crescido quase 20 vezes desde o primeiro Recenseamento realizado no Brasil, em 1872. (IBGE, 2011, p.30) ${ }^{12}$

Além disso, vale ressaltar que tal população não é distribuída de maneira uniforme no território, sendo a faixa litorânea e o espaço adjacente onde se concentra o maior contingente demográfico e, por conseguinte, as maiores densidades em termos de infraestrutura e produto interno bruto, com destaque para São Paulo e Rio de Janeiro, mas havendo também a importância das capitais localizadas em áreas não litorâneas, como Belo Horizonte (Minas Gerais) e Brasília (Distrito Federal). Torna-se relevante, entretanto, salientar que é na capital paulista "[...] o lugar por onde passam todas as redes de comunicação de alta capacidade e de longa distância, tanto nacionais quanto internacionais" (Toledo Junior, 2003, p.100).

Há, nesse sentido, diferenciações na conformação territorial do país, uma vez que há áreas de maior densidade técnica e outras com menor intensidade. Ademais, há de se destacar ainda que é na região concentrada (Sul e Sudeste do país), conforme Santos e Silveira (2006), que está presente a maior densidade do meio técnico-científico-informacional e por onde também circula a maior quantidade de capital e pessoas, enquanto as demais partes do território nacional apresentam outras especificidades e menor densidade e volume da técnica.

Lembrando que para Santos (2008) a densidade técnica pode ser entendida pelas diferentes formas de apropriação da natureza de modo a conceber o espaço pelo artificial, por meio de objetos técnicos. A densidade científica é amparada pelo número de centros de pesquisa e universidades, bem como pelo seu aspecto qualitativo de produção do conhecimento. A densidade informacional é vinculada à densidade técnica que, por sua vez, é introduzida por diferentes agentes sociais que dão a esse conteúdo intencionalidade, no campo da ação e intervenção, encaradas pelas necessidades humanas. Já a densidade comunicacional é derivada da prática humana, da ação

12 Sinopse do Censo Demográfico 2010. 
do tempo partilhado, não sendo resultante, por exemplo, do espaço banal da Geografia.

Consequentemente, tendo o Brasil como recorte espacial, o território usado como categoria, o tempo presente como recorte temporal e as telecomunicações como foco investigativo, é que se embasa o desafio interpretativo da pesquisa e se justifica essa proposição. Tempo presente esse que tem como marco prioritário o período pós-privatização das telecomunicações no Brasil e se estende até hoje com o uso corporativo do território.

Apesar do recorte espacial ser bastante amplo e diverso, sua escolha se justifica, então, por demonstrar justamente as contradições do fenômeno a ser estudado, já que há distintas regiões e realidades socioespaciais a serem compreendidas e não se negaria uma em razão da outra - embora existam áreas com maior presença de conteúdo técnico, científico e informacional, a exemplo de São Paulo.

O Brasil é hoje uma das maiores economias do mundo e no quadro das telecomunicações sua relevância é verificada internacionalmente, inclusive com a atuação de grandes empresas de capital externo, operando no mercado nacional. Além disso, deve-se mencionar que anteriormente o Estado brasileiro detinha o monopólio das telecomunicações (especialmente no setor da telefonia móvel e fixa).

Na página oficial do Banco Nacional de Desenvolvimento Econômico e Social (BNDES) é sintetizado esse quadro de transformação nos arcabouços legais de gestão do setor, quando descrito que:

Uma profunda reforma do aparato legal que regulava o setor tornou possível a reestruturação das telecomunicações brasileiras. O traço fundamental foi a transformação do monopólio público, provedor de serviços de telecomunicações, em um novo sistema de concessão pública a operadores privados, fundado na competição e orientado para o crescimento da universalização dos serviços.

A aprovação pelo Congresso Nacional da Emenda n. 8 à Constituição Federal, em 8 de agosto de 1995, permitiu ao Governo Federal outorgar concessões para exploração de serviços de telecomunicações 
ao setor privado. (Disponível em: <www.bndes.gov.br/SiteBNDES/bndes/bndes_pt/Institucional/BNDES_Transparente/Privatizacao/telecomunicacoes.html>. Acesso em: 21 set. 2015)

Assim, a abertura maior ao capital externo e a flexibilidade das leis relacionadas ao assunto ocorreram no âmbito do governo de Fernando Henrique Cardoso. Um dos primeiros passos para a mudança no setor foi a assinatura da lei n. 9.295 de 1996 (conhecida como Lei Mínima), em que foram estabelecidos os critérios para a concessão de serviços via satélite, à banda $\mathrm{B}$ da telefonia celular, bem como trunking and paging, ligados à formação de redes corporativas (Toledo Junior, 2003).

Foi a Lei Geral das Telecomunicações (LGT) n. 9.472 de 1997, entretanto, que determinou o novo modelo de funcionamento institucional, além da criação da Anatel (Agência Nacional de Telecomunicações), de planos de outorga e concessão, bem como do novo esquema tarifário e as diretrizes para a privatização da Telebrás (Telecomunicações Brasileiras S/A). Desse modo, ressalta-se que:

Segundo a Lei Geral, o processo decisório relativo à privatização do setor ficou a cargo de uma Comissão Especial de Supervisão, ligada hierarquicamente ao Ministério das Comunicações, e não sob a alçada do Conselho Nacional de Desestatização - CND, ao qual o BNDES se reportava em assuntos de privatização, como Gestor do Fundo Nacional de Desestatização - FND.

Em fevereiro de 1998, foi assinado Contrato entre o BNDES e o Ministério das Comunicações atribuindo-se ao Banco a coordenação da modelagem de venda e do próprio leilão do Sistema Telebrás (BNDES. Disponível em: <www.bndes.gov.br/SiteBNDES/ bndes/bndes_pt/Institucional/BNDES_Transparente/Privatizacao/telecomunicacoes.html>. Acesso em: 21 set. 2015). 
E, nessa perspectiva:

A privatização do Sistema Telebrás ocorreu no dia 29 de julho de 1998 através de 12 leilões consecutivos na Bolsa de Valores do Rio de Janeiro - BVRJ, pela venda do controle das três holdings de telefonia fixa, uma de longa distância e oito de telefonia celular, configurando a maior operação de privatização de um bloco de controle já realizada no mundo. Com a venda, o governo arrecadou um total de $\mathrm{R} \$ 22$ bilhões, um ágio de 63\% sobre o preço mínimo estipulado. (Disponível em: <www.bndes.gov.br/SiteBNDES/ bndes/bndes_pt/Institucional/BNDES_Transparente/Privatizacao/telecomunicacoes.html>. Acesso em: 21 set. 2015)

Já no cenário posterior ao monopólio estatal, segundo dados consolidados do Portal da Anatel para junho de 2010, em referência ao quantitativo de acessos móveis e participação de mercado no Brasil, a Vivo concentrava 30,24\% - o que equivale, em números absolutos, a 55.977.308 acessos; a Claro 25,33\% (46.901.528 acessos); a Tim 24\% (44.424.855 acessos); a Telemar/Brasil Telecom 20,08\% (37.168.927 acessos); e, por fim, compareciam empresas que não conseguiram alcançar a cifra de $1 \%$ dos acessos, ou seja, a CTBC Celular, Sercomtel Celular e Unicel do Brasil Telecomunicações. O montante totalizava 185.134.974 de acessos por mês.

No segmento da televisão por assinatura, conforme dados do documento "Panorama dos Serviços de TV por assinatura" da Anatel, para junho de 2010, eram 8.426.462 de assinantes no Brasil, distribuídos nos mais diversos segmentos, como tecnologia via satélite, cabo e outras. Em termos de competição no mercado, o grupo NET era o que possuía o maior número de assinantes: 3.874 .282 , o que equivalia a $45 \%$ do total; a Sky possuía 2.179 .525 de assinantes (26\%); a Embratel 655.710 (8\%); a Telefônica 468.812 (6\%); a Oi 344.241 (4\%); a Abril 166443 (2\%) e as demais empresas instaladas no território nacional somavam 737.449 assinantes (9\% do total).

Agora, no que diz respeito ao segmento de internet, observa-se grande pulverização no mercado de provedores (conforme observa- 
do no Portal da Anatel), compondo uma listagem bastante extensa de empresas locais, regionais e outras que têm maior visibilidade nacionalmente, das quais compareciam: UOL (grupo Folha), Terra (Telefônica), Brasil Telecom (IG, Ibest e BrTurbo) e Globo (Organizações Marinho). Segundo pesquisa IBOPE, disponível no site da consultoria Teleco, eram 94,2 milhões de usuários da internet no Brasil para o terceiro trimestre de 2012. Além disso, verifica-se grande variedade nas formas de conexão disponíveis no mercado como a banda larga, discada, via rádio, rede elétrica etc.

Portanto, são essas empresas ${ }^{13}$ mencionadas nos segmentos da telefonia celular, internet e televisão por assinatura que compõem parte do recorte de pesquisa. A eleição destas decorre, nesse sentido, da relevância econômica que possuem, da atuação territorial que desempenham, do faturamento total anual que auferem, contribuindo, por fim, para a interpretação geográfica do fenômeno das telecomunicações e da informação no território brasileiro.

Por outro lado, há de se ressaltar que esse mercado é tão dinâmico que algumas alterações substanciais foram sendo processadas com o passar do tempo. Grupos que antes agiam de forma individualizada e particularizada se uniram dando origem a empresas ainda mais fortes e competitivas. Além disso, algumas companhias passaram a possuir novos nomes comerciais, composição acionária, bem como oferta integrada na forma de combos de determinados serviços.

Pode-se escrever, portanto, que há um oligopólio em operação no setor. Tal discussão será apresentada, mais adiante, tendo como principal embasamento referências como Sweezy (1939), Carvalho (2000), bem como Sauaia e Kallás (2007). Isto permite, por sua vez,

13 Nessa perspectiva, é preciso frisar que, ao longo do tempo, essas companhias elegidas para estudo passaram por diferentes transformações societárias, bem como sofreram até mesmo alteração de nome. Assim, por se tratar de um mercado bastante dinâmico e cambiável, a presente pesquisa ao final apresenta na televisão paga: NET, Claro, Sky, Vivo TV e Oi TV; nos provedores de internet: UOL, Terra, IG e Globo.com; e no segmento de telefonia celular: Vivo, Tim, Claro e Oi. Tais companhias são resultantes das citadas nos parágrafos anteriores. 
identificar como se construiu territorialmente o processo de privatização e traz também para a discussão dados como da internacionalização e regionalização do setor no Brasil e na América Latina. Além disso, procurar-se-á demonstrar os novos arranjos patrimoniais das companhias e, em última medida, expor suas parcerias estratégicas de mercado. 


\section{1 \\ A gEOGRAFIA E AS TELECOMUNICAÇÕES}

\section{As telecomunicações como problema geográfico e de desenvolvimento desigual: principais referências e o movimento das transformações socioespaciais}

O tema das telecomunicações tem sido discutido em diversos trabalhos científicos no mundo, não se restringindo ao universo de compreensão das Ciências Humanas, mas sendo debatido de diferentes maneiras e sentidos pelas Ciências Exatas e Biológicas. Porém, foi nas engenharias e ciências voltadas à aplicação da técnica que seu uso e desenvolvimento têm sido mais pragmáticos, com a finalidade de revolucionar e promover o movimento de inovações. Isso porque o que se faz nas Ciências Humanas, em geral, é a interpretação de seu significado e repercussão desse evento da técnica na sociedade.

No Brasil, pode-se afirmar que alguns dos primeiros estudos de cunho geográfico sobre telecomunicações datam do fim da década de 1980 e anos 1990. Na Geografia, é desse período a tese elaborada por Leila Dias (1991), na França, que interpreta a análise da rede urbana e da informação no Brasil. Esse trabalho possibilitou, sem 
sombra de dúvidas, a construção de um arcabouço teórico para a interpretação da evolução das telecomunicações ao lançar luz sobre a formação das redes técnicas, bem como a produção da rede urbana, sendo publicado também a posteriori na forma de livro. Dessa obra, emerge a fundamentação principal de fundo da abordagem da evolução das infraestruturas de telecomunicação no país, somada, evidentemente, a contribuição de outros autores, em variados contextos e campos do conhecimento, como Brandão (1996), Novaes (2000), Iozzi (2006), Mamigonian (2009), entre outros.

Hindenburgo Francisco Pires, da Universidade do Estado do Rio de Janeiro, é outro autor brasileiro que tem publicado diversos trabalhos voltados à compreensão do fenômeno das telecomunicações. O tema de sua dissertação de mestrado, por exemplo, é sobre a gestão urbana e tecnologia da informação e data do final da década de 1980. Já sua tese de doutorado, datada de 1995, foi defendida na Universidade de São Paulo e tratou, também, de assunto correlato à análise das telecomunicações no Brasil. Em seu conteúdo é possível verificar a análise da Geografia Econômica pelo estudo da reestruturação industrial por meio do enfoque e atenção ao segmento da alta tecnologia, tendo como recorte espacial o Brasil.

Os textos produzidos por esse autor têm versado, sobretudo, acerca da Cibergeografia, as metamorfoses tecnológicas do capitalismo e da análise da internet no Brasil e América Latina. Para tanto, até organizou um sítio eletrônico para disponibilizar o material produzido por ele, com o título de Cibergeo, no sentido de divulgar suas ideias e contribuir para a discussão do tema. Assim, de Pires (2005) utilizar-se-á, sobretudo, sua contribuição para compreender a morfologia da internet no Brasil, por meio de contextualização histórico-geográfica.

Mesmo com estes esforços e de outros investigadores com trabalhos posteriores, ressalta-se que as reflexões sobre as telecomunicações na Geografia Econômica têm de ganhar maior visibilidade no meio acadêmico, como destacou Gillespie (1988) em livro organizado por Bakis et al. (1988) ao ressaltar que: "Telecommunications geography has not occupied a significant position within the broader 
field of economic geography" (p.61). Equívoco seria assinalar, desse modo, que os estudos dessa envergadura são reduzidos, embora esse não seja um daqueles de maior destaque na produção da Geografia nacional e internacional.

$\mathrm{Na}$ França, a preocupação com as técnicas da informação e das telecomunicações é antiga e se estruturou a partir de várias vertentes teóricas. Em 1983, é criado, por exemplo, o primeiro periódico para debater o assunto denominado Réseaux, por iniciativa do CNET (Centre National d'Etudes des Télécommmunications).

Nesse sentido, o livro Geópolitique de l'information, de Bakis (1987), traz referência ao debate da informação sob a ação da Geopolítica, demonstrando em seu conteúdo articulações com a sociedade, com aspectos culturais e da organização da Economia. Satélites e cabos submarinos fazem parte, portanto, dessa nova configuração técnica, na qual o acesso e controle da difusão da informação são cada vez mais importantes para as decisões estratégicas de empresas, governos e das pessoas, diariamente.

Também de autoria de Bakis (1990) é a iniciativa de organização do livro Communications et territories. Deste trabalho pode-se mencionar textos de significativa contribuição geográfica para o assunto das telecomunicações, como Télécommunications et dynamique spatiale: le cas du Brésil, de Tamara Benakouche e Leila Dias, que abordam as transformações radicais desse segmento no Brasil a partir de 1962, com a criação dos órgãos estatais que iriam gerir o segmento.

Michel Chesnais, nessa mesma obra, retratou a informação e as estratégias espaciais das empresas, demonstrando relevância para a pesquisa na área de telecomunicações, bem como para a compreensão do espaço pela atuação das corporações. Para esse autor haveria um espaço da empresa que poderia ser caracterizado pelo instrumental geográfico e, assim:

L'espace de l'entreprise est caractérisé par une gamme de paliers géographiques, dont la mise en connexion constitue l'um des préalables à son fonctionnement. Ainsi entreprise ou établissment ne 
peuvent être assimiles à un site. Non seulement la dimensión des site diffère, mais encoré l'inscription des entreprises dans les sites est variable. Une entreprise peut occuper plusieurs établissements distincts dans le même site [...] L'usage des variations d'échelle dans la prise en compte des états géographiques de l'entreprise constitue ainsi un aspect fundamental. (Chesnais, 1990, p.155)

Com isso, as empresas apresentam lógicas distintas de atuação e podem, inclusive, dividir e compartilhar o mesmo espaço. No Brasil, esse argumento auxilia a sustentar a afirmação de que as empresas privadas de telecomunicação fazem o uso corporativo de determinados territórios, compartilhando as mesmas infraestruturas técnicas e oferecendo ao consumidor preço às vezes distintos para acessar certos tipos de serviço, como ocorreu com as redes de internet $4 \mathrm{G}$ recentemente (que será mais bem detalhado mais adiante).

Dimitri Ypilantil, ainda nesse livro de organização de Bakis (1990), foi outro autor de preocupação geográfica ao examinar as telecomunicações e o desenvolvimento regional. Para Y pilantil (1990, p.298), as telecomunicações e tecnologias da informação estão produzindo grandes alterações na economia e, portanto, "[...] are increasingly pervasive in manufacturing and service sectors, and they are leading to profound changes in the economy and in society at large $[\ldots]$ "..

Há, porém, outras contribuições teóricas relevantes no caso francês. ${ }^{1}$ Offner (2000) é um desses autores mais citados quando tratou dos efeitos da não regulação territorial a partir da ação política de determinadas autoridades e da análise das redes técnicas.

Curien e Gensollen (1985), igualmente, são autores debatidos na literatura francesa e internacional sobre o tema e serão utilizados

1 Loïc Grasland da Université d'Avignon et des Pays de Vaucluse, localizada na França, produziu algumas publicações a respeito das tecnologias da informação, mas grande parte de suas publicações têm sido associada à cartografia espacial e não serão incorporados ao presente trabalho. 
neste livro para o estudo das redes técnicas, com os conceitos ${ }^{2}$ de redes-suporte e serviços-redes.

Já sob a direção de Pierre Musso (2003) foi editado o livro Réseaux et Societé com diversos textos sobre redes, inclusive, técnicas. Da obra de Musso cita-se o artigo de Alain Gras (2003), que buscou retratar a origem dos sistemas técnicos atuais por meio da análise das redes, máquinas e megamáquinas.

Nesse sentido, Gras procurou elucidar como tese principal de seu escrito de que a evolução da técnica também causa transformação nas redes. Dele é a ideia de que o telégrafo foi a primeira invenção técnica na forma de máquina ao propiciar alterações no modo de compreensão das redes, ao afirmar que: "[... ] l'invention de la première machine à communiquer instantanément à distance, le télégraphe, va modifier la physinomie de l'ancien réseau [...]”. (Gras, 2003, p.147).

De língua inglesa, menciona-se a contribuição de Mark E. Hepworth (1990), que produziu a obra Geography of the information Economy. Nela é debatido especialmente o papel da informação na economia, informação tecnológica como sistema espacial, capital informacional e os modelos econômicos regionais, redes de computadores em firmas que mantêm operação em diversas partes do mundo e a discussão da cidade da informação, no período contemporâneo.

Sobre o assunto da tecnologia e da informação Hepworth (1990) sintetiza parte da sua argumentação quando considerou a possibilidade da convergência tecnológica a partir do computador, sendo que:

[...] As new elements of the capital stock, used by firms, governments or the household, these technologies are now transforming production techniques in all sectors, methods of management and forms of industrial organization, the product composition and contours of markets and modes of consumption [...]. (Hepworth, 1990, p.39)

2 Tais ideias serão mais bem descritas no tópico seguinte. 
Neste cenário, fica claro que a convergência produzida a partir dos avanços da técnica e do computador é cada vez mais importante na sociedade, nos variados setores da economia. Além disso, no universo da literatura estrangeira de língua inglesa sobre o tema deve-se mencionar o livro Shaping technology/Building society: studies in sociotechnical change de Bijker e Law (1992) e a obra organizada por Brunn, Cutter e Harrington (2004) denominada Geography and Technology.

Mas é, sem sombra de dúvidas, os trabalhos de Manuel Castells os mais citados no idioma inglês e os que tiveram maior repercussão teórica para analisar o papel da informação na sociedade e no capitalismo. Esse autor, mesmo não sendo geógrafo, mas de formação na Sociologia, apresenta contribuição de caráter geográfico para a discussão do assunto. Lecionou na França, Espanha e Estados Unidos, escreveu diversos trabalhos e debateu intensamente as transformações do capitalismo no período atual, trabalhando a ideia de capitalismo informacional. Além disso, esse pesquisador tem utilizado termos como sociedade informacional e Geografia da Internet para expor os resultados da integração entre mercado e informação. A Geografia da Internet, por sua vez, seria dividida em Geografia Técnica, Geografia dos Utilizadores e Geografia Econômica.

$\mathrm{Na}$ interpretação de cunho crítica, observa-se que O Capital, escrito por Karl Marx (1985a, 1985b, 1985c), não trabalhou diretamente com argumentações aprofundadas dos meios de comunicação, descrevendo tal assunto no processo social de reprodução da economia capitalista. Já no Grundrisse, outra obra de Marx, observa-se que a expressão comunicação é empregada, sobretudo, na seção II, sendo descritos os meios de comunicação e transportes nos custos de circulação e, portanto:

[...] Circulation as we regard it here is a process of transformation, a qualitative process of value, as it appears in the different form of money, production (realization) process, product, retransformation into money and surplus capital [...]. (Marx, 1993, p.524) 
Nesse entendimento, a circulação é vista a partir também do custo que pode gerar a uma determinada mercadoria, indo muito além da descrição geométrica de um espaço abstrato para ganhar a conotação de um espaço de luta de classes como motor da história.

Assim, na literatura sobre as telecomunicações, observa-se, em muitos casos, que o assunto é associado ao desenvolvimento econômico, à melhoria das condições de vida da população, ao acesso amplo à comunicação e à informação de qualidade. Não são mencionadas, em grande parte dos estudos, as desigualdades socioespaciais dos diferentes países e mesmo as desigualdades internas em suas distintas escalas, isto é, cidades, campo, regiões e estados, dando a conotação de uma interpretação neutra da realidade e desprovida de sentido geográfico e de movimento histórico.

Nesse cenário, é importante frisar que o acesso à informação é também fonte de poder que auxilia no processo de crescimento de diversas partes do território. Tal argumentação é pautada naquilo que Sposito escreveu ao argumentar que:

O acesso à informação é na, atualidade, uma condição vital para a sociedade; e ela mesma (a informação) se torna fonte estratégica para o desenvolvimento de empresas industriais e para a adaptação na sociedade informática, das pessoas às transformações contemporâneas observáveis, principalmente nas metrópoles e nas cidades intermediárias. (Sposito, 2008, p.107)

Ademais, nos últimos anos, a temática das telecomunicações ganhou posição central como elemento discursivo para o debate do desenvolvimento nacional de diversos países. Há de se notar, entretanto, que esse discurso foi acompanhado por medidas liberalizantes na economia, por concessões e privatizações, especialmente na década de 1990.

Para privatizar o setor e, por extensão, o uso do território, o discurso neoliberal da época afirmava que grande parte dos Estados Nacionais já não tinham mais as condições financeiras necessárias para bancar o processo de modernização do segmento, investir em 
infraestrutura técnica e garantir a universalização do sistema. Isso se dava em razão do pagamento de juros altíssimos da dívida externa (contraída ao longo de anos de ajustes macroeconômicos) junto a instituições de crédito internacional, a exemplo do Banco Mundial e do Fundo Monetário Internacional.

Sustentados por esse discurso, alguns países da América Latina, nas décadas de 1980 e 1990, foram sacudidos por uma onda privatista no setor de telecomunicações. Os governos, em geral, alegavam o sucateamento das infraestruturas técnicas e difundiam a ideia de que o modelo de privatização e concessão seria bom, porque garantiria melhoria dos serviços prestados, além da diminuição de preços e tarifas, em razão da concorrência entre diferentes empresas que disputariam o mercado futuramente.

Portanto, tendo em vista esse cenário, a expressão "concessão" será entendida enquanto sinônimo de privatização, mesmo que se trate de regimes jurídicos diferentes. Na privatização, ocorre a venda direta das empresas estatais à iniciativa privada, como ocorreu com a Companhia Vale do Rio Doce e o governo saindo diretamente de cena. Por outro lado, as concessões não deixam de ser de certa maneira um mecanismo de privatização do uso do território.

Ao conceder, o governo repassa às instituições privadas não só infraestruturas, mas também transfere sua responsabilidade, coordenação e gestão para estas, embora considere-se que tais bens são inalienáveis, ou seja, não podem ser cedidos ou vendidos e devem, ao final da concessão, serem devolvidos ao Estado. Com isso, mesmo que se afirme que o governo possui o poder de fiscalização sobre as companhias e o controle sobre os contratos, quem gerencia o negócio são as corporações.

O coroamento da privatização das telecomunicações na América Latina foi, então, um leilão vencido por grandes corporações internacionais que passaram a operar com diferentes estratégias de atuação, desenvolvendo políticas territoriais complexas. O Chile, nesse caso, foi um dos primeiros países na América Latina a desencadear privatizações no setor. Sobre o tema, Graciela Moguillansky 
(1998), em estudo sobre as reformas e comportamento de investimentos em telecomunicações, descreveu que:

En un contexto en que la política de estabilización obligaba al gobierno a mantener tarifas por debajo de la inflación, lo que imponía pérdidas sobre las empresas estatales, en 1978 se anuncia una nueva política de telecomunicaciones, que enfatizó la importancia del sector en el desarrollo económico, el rol del sector privado en esta dinámica y la necesidad de eliminar el trato especial a la empresa estatal. Sin embargo hasta 1982, esta política no fue implementada y fue recién con la Ley General de Telecomunicaciones (Ley 18/168 de 1982), y sus posteriores modificaciones, que se crearon al igual que lo ocurrido en el sector eléctrico1, los incentivos y las condiciones para la privatización del sector. (Moguillansky, 1998, p.10)

Porém, é preciso ressaltar que tal processo se deu em várias etapas e, desse modo, foi a Lei Geral de Telecomunicações, em 1982, que possibilitou alterações ainda mais profundas para o setor " [...] promoviendo la participación de los agentes privados, introduciendo los principios del libre mercado e impulsando la competencia". (Moguillansky, 1998, p.13)

Tal processo foi acompanhado por diversos países no continente, a exemplo da Argentina, México e Brasil, mas cada um guardando determinadas especificidades e momentos particulares de abertura e, nesse caso: "El proceso de privatización, desmonopolización y desregulación de las telecomunicaciones significó una profunda modificación en el rol del Estado, que paró de ser prestador de los servicios a desempeñar tareas de regulación y control [...]" (Schifer; Porto, 2002, p.99).

Já o caso mexicano "[...] constituye sin duda un ejemplo paradigmático del nacionalismo en el proceso de privatización y apertura de las telecomunicaciones [...] (Rivera Urrutia, 2008, p.76) e, nesse sentido, "[...] La empresa se privatizó como un monopolio nacional verticalmente integrado, concediéndosele además un período de exclusividad de seis años [...]" (Rivera Urrutia, 2008, p.76). 
Com essa medida, o governo fortaleceu a Telmex, que foi privatizada, permitindo uma política fiscal favorável à companhia com taxa de lucro alta, protegendo-a para no futuro enfrentar a concorrência internacional que se avizinhava.

Vários são os exemplos que poderiam ser mencionados nesse universo de privatização territorial e das empresas estatais. Com isso, o entendimento do uso corporativo do território é chave para a reflexão não somente de um processo que ocorreu em um continente, mas também serve para esclarecer os arranjos institucionais daí estabelecidos ao colocar:

[...] ao pensamento geográfico uma instigante encruzilhada. Vivemos em um continente no qual os processos de globalização alcançaram velocidades nunca vistas antes, graças às forças dos agentes envolvidos e à criação de condições internas propícias a essa dinâmica [...]. (Silveira, 2006, p.85)

Assim, os governos latinos prepararam o território para a globalização, bem como para uma nova normatização territorial, flexível e corporativa, sendo que cada país pôde, ao longo desse período, produzir uma síntese política e econômica própria para experimentar tal realidade.

Tozi (2009), sobre a preparação do território para as privatizações no Brasil na década de 1990, destacou que houve um processo de fragmentação para o uso do território pelas empresas privadas. Tal categoria geográfica, por sua vez, passa a ser vista como recurso para a operação das companhias, embora estas compartilhem, por via das vezes, as mesmas infraestruturas técnicas em dada porção do país e, portanto:

Preparando o território para a privatização das telecomunicações adotou-se uma reserva estatal de áreas específicas para cada empresa. Como as divisões e regras finais sobre a privatização couberam ao Estado (apoiado em consultorias privadas), pode-se dizer que ele escolheu, facilitando ou dificultando a concorrência tal ou 
qual grupo, quais empresas teriam prioridades de ação no território [...]. (Tozi, 2009, p.54)

Com isso, as telecomunicações representam um evento da técnica que atinge diretamente a sociedade contemporânea, envolvendo o mundo do trabalho, a vida cultural e as relações cotidianas entre as pessoas por meio da difusão das "Tecnologias da Informação e Comunicação” (TICs), quer seja no Brasil ou no mundo. Nesse caso, as telecomunicações revelam que as barreiras físicas não são um constrangimento à transmissão da informação. A comunicação tem o poder de estar presente em todos os espaços, seja pela difusão em ondas, seja pelos fluxos, estabelecidos a partir da utilização de fibras ópticas e de outros terminais de comunicação digital; embora, seja necessário levar em conta que ainda persistem, em alguns casos, "zonas cegas" onde a comunicação é limitada.

No processo de comunicação são instaladas, portanto, redes técnicas no território. Redes essas alimentadas pelos mais variados sistemas técnicos de comunicação que compõem em conjunto as telecomunicações e o processo de integração da sociedade em seu movimento informacional.

Raffestin (1993), sobre a matéria, sublinhou que a comunicação se refere ao processo que leva em conta um conteúdo específico, ou seja, a informação. Não há comunicação sem informação e vice-versa, e:

A circulação e a comunicação são duas faces da mobilidade. Por serem complementares, estão presentes em todas as estratégias que os atores desencadeiam para dominar as superfícies e os pontos por meio da gestão e do controle das distâncias. Falaremos de circulação cada vez que se trate da transferência de seres e de bens lato sensu, enquanto reservaremos o termo "comunicação" a transferência da informação. (Raffestin, 1993, p.200)

O autor exemplificou ainda que se deve fazer uma distinção necessária entre comunicação e circulação, pois a comunicação se 
relaciona mais à transmissão de mensagens em poder e energia, enquanto a circulação se refere ao transporte de bens e homens. Para Raffestin, a informação é um bem que tem poder para circular, ao passo que no transporte há circulação e comunicação.

Ao se avaliar o papel da informação nas transformações socioespaciais recentes se faz necessário centrar o debate, sobretudo, na perspectiva crítica teórica de Raffestin (1993), visto que para se avaliar o uso corporativo do território, no setor das telecomunicações, é preciso também identificar as lógicas de controle da comunicação e de difusão da informação, arquitetadas pelas empresas e suas estratégias geográficas.

A tecnologia moderna foi a responsável pela cisão entre comunicação e circulação. Se a informação pode ser recebida de modo praticamente simultâneo pela comunicação, bens e homens não podem no processo de circulação. Por conseguinte, depreende-se que "A verdadeira fonte de poder deve, portanto, ser procurada bem mais na comunicação que na circulação [...]”' (Raffestin, 1993, p.202).

A difusão das tecnologias modernas que promoveram a disjunção entre comunicação e circulação é muito ampla, abrangendo espaços nacionais, regionais e locais: dos mais desenvolvidos aos menos desenvolvidos economicamente. Ademais, é possível mencionar que do Senegal aos Estados Unidos da América se tenha telefone celular e outros aparelhos técnicos que provocam transformações econômicas e sociais, imprimindo um sentido de aceleração da comunicação.

Cabe igualmente destacar que o acesso a tais tecnologias é restrito àqueles sujeitos que tenham condições financeiras mínimas para adquiri-los, não sendo usufruídos por toda sociedade de modo igualitário. Autores como Milton Santos (2001) e Manuel Castells (2003) já haviam discutido tal contexto e contribuem para formular reflexões acerca da matéria.

Castells (2003), ao debater a questão da internet e da sociedade informacional, foi enfático em afirmar que: "[...] A geografia das redes é uma geografia tanto de inclusão quanto de exclusão, dependendo do valor atribuído por interesses socialmente dominantes a 
qualquer lugar dado [...]" (Castells, 2003, p.196) e, em outro trecho da mesma obra, comentou que a internet é a "tecnologia da liberdade", mas que esta "[...] pode libertar os poderosos para oprimir os desinformados, pode levar à exclusão dos desvalorizados pelos conquistadores do valor. Nesse sentido geral, a sociedade não mudou muito $[\ldots] ”($ p.225).

Já Santos (2001) comentou que vivemos em um período "globalitário", ou seja, de globalização totalitária, onde o que impera é a tirania da informação e do dinheiro, uma vez que: "Tirania do dinheiro e tirania da informação são os pilares da produção da história atual do capitalismo globalizado. Sem o controle dos espíritos seria impossível a regulação pelas finanças" (Santos, 2001, p.35). Isso porque aquilo que nos fazem ver por meio das grandes corporações e da mídia é uma "globalização como fábula" (Santos, 2001) assentada, sobretudo, na ideia de uma suposta "aldeia global" e de um mundo sem fronteiras e integrado.

Ainda segundo Santos (2001), haveria, então, uma "globalização perversa", isto é, tal como ela é de fato: excludente, desigual e que beneficia a poucas pessoas e corporações no quadro da produção de uma mais-valia mundializada e, por fim, haveria uma "globalização como possibilidade", sendo esta entendida como ela poderia vir a ser se utilizada a favor da integração social e das variadas comunidades, abrangendo a noção de um mundo mais justo socialmente.

Já para Dicken (1998), no livro Global shift, existiria uma diferenciação entre globalização e internacionalização quando argumentou que:

[...] that globalization is a complex of inter-related process, rather than an end-state such tendencies are highly uneven in time and space. In taking such a process-oriented approach it is important to distinguish between process of internationalization and process of globalization. (Dicken, 1998, p.5, grifo do autor)

Nessa concepção, a internacionalização leva em conta um processo quantitativo de multiplicação de atividades econômicas. Já 
a globalização é um processo qualitativo que é caracterizado pela integração funcional das atividades para além das fronteiras nacionais, sendo que ambos os processos coexistem. Integração funcional essa que só pode ser compreendida à luz das tecnologias da informação, no contexto das telecomunicações.

Com isso, na Geografia, a relevância das telecomunicações e das TICs é notável, dado o particular interesse pelo estudo do espaço, da espacialidade e dos impactos que tais tecnologias produzem na sociedade, permitindo a conexão de diversos pontos do globo de modo simultâneo, em escala virtual e integrada e, por conseguinte:

O fenômeno da simultaneidade ganha, hoje, novo conteúdo. Desde sempre, a mesma hora do relógio marcava acontecimentos simultâneos, ocorridos em lugares os mais diversos, cada qual, porém, sendo não apenas autônomo como independente dos demais. Hoje, cada momento compreende, em todos os lugares, eventos que são interdependentes, incluídos em um mesmo sistema de relações [...]. (Santos, 1998, p.8)

Nesse contexto, verifica-se que a Geografia não foi superada e não perdeu seu sentido interpretativo da realidade, ou seja, não foi decretada a sua morte. Porém, o que houve de fato foi a tendência à superação das distâncias em um curto espaço de tempo. Nessa "aceleração contemporânea do tempo e do espaço" (Santos, 1998) as distâncias se tornaram cada vez menores em um curto período de tempo, em razão do advento de novas tecnologias de transporte e comunicação.

Nesse universo, a afirmação de que a Geografia e a História perderam seu significado é falsa. Ademais, o que há de fato a se considerar é que as telecomunicações são um evento de caráter espacial da técnica e da normatização do território, o que coloca, por outro lado, tal situação como um problema científico e o insere como desafio analítico geográfico para sua devida compreensão e explicação.

As TICs, nesse aspecto, permitem superar uma barreira fundamental que é aquela concernente à distância entre diferentes loca- 
lidades, associada a um tempo e um espaço específico, permitindo o acomodamento de novas organizações socioespaciais. Ademais, esta é uma revolução aparentemente irreversível e cujos reflexos ainda são difíceis de prever, uma vez que tais mudanças se encontram em curso e possuem desdobramentos profundos na economia e na política e, por isso:

O fato de que o processo de transformação da sociedade industrial em sociedade informacional não se completou inteiramente em nenhum país, faz com que vivamos, a um só tempo, um período e uma crise, e assegura, igualmente, a percepção do presente e a presunção do futuro, desde que o modelo analítico adotado seja tão dinâmico quanto a realidade em movimento e reconheça o comportamento sistêmico das variáveis novas que dão uma significação nova à totalidade. (Santos, 1992, p.7)

A partir da análise desse quadro caberia frisar, então, que a difusão das telecomunicações trata-se claramente de um problema geográfico e também econômico ao apontar onde serão localizadas determinadas infraestruturas técnicas, equipamentos de serviço, comércio e indústria e, consequentemente, assinalar desigualdades socioespaciais, trazendo à tona a noção de desenvolvimento desigual e combinado do espaço (Trotsky, 1967).

Dessa forma, tendo a história como ponto de partida é possível afirmar que não houve até o momento na evolução da humanidade desenvolvimento homogêneo das técnicas e do espaço, o que dá a essa interpretação caráter de lei da sociedade. A verificação desse princípio não é nova e sua reflexão já ocorria entre filósofos gregos há mais de dois mil anos. Entretanto, sua sistematização só foi se processar de modo lento e gradual no século XX.

Assim, cabe frisar que o termo desenvolvimento desigual e combinado foi cunhado no âmbito da teoria social crítica marxista e ficou mais bem evidenciado nos trabalhos elaborados por Leon Trotsky $(1967,1978)$. Tal autor verificou que na história havia a possibilidade da construção de saltos no tempo e a superação do 
atraso pelo movimento de incorporação de tecnologias avançadas dos países desenvolvidos.

Nesse sentido, Trotsky sintetizou suas ideias acerca do desenvolvimento desigual e combinado ao expor que essa expressão "[...] significa uma aproximação das diversas etapas, combinação das fases diferenciadas, amálgama das formas arcaicas com as mais modernas [...]" (Trotsky, 1978, p.25). Ademais, há de se destacar que o uso dessa expressão também foi incorporado de modo pontual pelos marxistas modernos ao exporem interpretações acerca do neoimperialismo e do modelo de acumulação do capital, desempenhado especialmente a partir da exploração de colônias, em diversas partes do mundo, por algumas nações da Europa Ocidental.

$\mathrm{Na}$ Geografia, a discussão sobre o desenvolvimento desigual tem ganhado diferentes interpretações. Para Soja (1993), por exemplo, a retomada dessa discussão representa, em sentido geral, a reafirmação do espaço na teoria social crítica marxista. Poderiam ser citados, nesse contexto, autores e trabalhos de diversas vertentes e posicionamentos teóricos como David Harvey (1982) em sua obra The limits to capital; Neil Smith (1988) no livro Desenvolvimento Desigual; entre tantos outros que produziram argumentações acerca da diferenciação espacial e do desenvolvimento desigual.

Mesmo com essas constatações, as ideias de Trotsky pouco têm sido debatidas na Geografia e seria importante resgatar, nessa concepção, um interessante embasamento para os estudos espaciais e da dinâmica econômica, algo que comparece na presente investigação.

No caso brasileiro, verifica-se que o país em pouco tempo cresceu economicamente no século XX e avançou sobre o processo de industrialização, mesmo que de modo tardio, incorporando a tecnologia que foi produzida, na escala de séculos, em outros países. Inglaterra e Estados Unidos já haviam produzido revoluções industriais em seu território e o Brasil procurou assimilar tais transformações, em curto período de tempo, abrindo seu mercado fortemente ao investimento externo e à ação de grandes corporações, em variados segmentos de tecnologia, como ocorreu nas telecomunicações, no século XX. 
Com isso, as tecnologias da informação produzem diferenciações espaciais e reforçam o sentido de heterogeneidades das localidades. Lembrando que para Santos (2008, p.42): "Num mesmo pedaço de território, convivem subsistemas técnicos diferentemente datados, isto é, elementos técnicos provenientes de épocas diversas".

Nem todos os espaços são equipados com a mesma densidade técnica. A maior concentração de ciência, tecnologia e informação em um determinado local está associada, geralmente, a espaços que apresentam grande densidade demográfica e onde a reprodução do capital é mais elevada. Além disso, há distinções quanto ao uso e consumo que são feitos dessas tecnologias, em razão especialmente do poder aquisitivo diferenciado de grupos específicos da população.

Todas essas barreiras funcionam como uma espécie de constrangimento de ordem socioespacial e são detectadas entre países mais ricos e menos ricos, entre espaços rurais e urbanos, entre espaços metropolitanos e outros de menor patamar demográfico. Mas a maior clivagem que expõe o fenômeno da desigualdade no consumo e apropriação desses objetos são as fraturas referentes à má distribuição de renda que demonstram porque determinados espaços são dotados de maior densidade técnica e econômica e, com isso, assinalar que:

A difusão espacial dos sistemas técnicos atuais no Brasil, nas formas de produção de um conhecimento digital e da comunicação de dados entre empresas, reestrutura a repartição de trabalho morto e do trabalho vivo no território, aprofunda a especialização funcional dos lugares sob o comando de grandes capitais, impõe uma fragmentação espacial cuja lógica encontra na política territorial das grandes firmas, gera novos espaços alienados (Isnard, 1982) com a implantação de redes extrovertidas, hierarquiza o conhecimento do meio. (Castillo, 2003, p.50 e 51)

Portanto, torna-se necessário pensar em termos de uso o modo como são difundidas essas infraestruturas e tecnologias no território, fazendo com que seu componente ativo de inovação traga 
elementos de riqueza ou pobreza a distintas áreas, detectando as contradições presentes nessa lógica e apontando, se possível, para sua superação.

Assim, cabe frisar, por exemplo, que a instalação de fibras ópticas e de outros equipamentos técnicos de telecomunicação quase sempre está associada aos grandes centros e aos eixos principais de circulação de pessoas, dinheiro e de matérias-primas. Para o caso brasileiro, é válido comentar, conforme Santos e Silveira (2006, p.81), que:

[...] O Estado de São Paulo, em 1995, reunia 48\% dos 300 mil quilômetros de fibra óptica do Brasil. Inovação fundamental nos sistemas de engenharia, fibra óptica estende-se, nos seus segmentos terrestres, ao longo de rodovias, ferrovias e dutos enquanto os cabos aéreos de sua rede são solidários com as linhas de eletricidade, de São Paulo ao Sul do país [...].

Nesse sentido, observa-se uma nítida concentração de infraestrutura técnica. De acordo com Toledo Junior (2003, p.101): "Dada a presença de várias redes de fibra óptica interligando as cidades de São Paulo, Rio de Janeiro e Belo Horizonte, as cidades que se situam nesses eixos acabam por ter um acesso privilegiado às redes". Acerca desse fato Toledo Junior (2003, p.101 e 102) novamente dá o devido suporte teórico a essa reflexão, considerando que:

Em uma referência ao vidro, material utilizado na confecção de cabos de fibra óptica, a Pegasus Telecom (100\% controlada pela AG Telecom - Andrade Gutierrez) denominou Triângulo de Cristal o seu projeto de implantação de redes entre São Paulo, Rio de Janeiro e Belo Horizonte. Esse nome é sugestivo não somente pelo projeto da Pegasus Telecom, que tem capacidades de transmissão de dados inimagináveis há poucos anos, mas pela sobreposição, neste triângulo, de redes de fibra óptica de diversas outras empresas. Tal sobreposição faz com que essa área seja a mais bem servida pelos mais diversos tipos de serviços de telecomunicação, diferenciando-se assim do restante do território nacional. 
Nesse Triângulo, estão concentradas as sedes das grandes corporações que têm atuação em âmbito nacional e forte articulação com o exterior, os maiores PIBs (Produto Interno Bruto) do Brasil, bem como universidades importantes, centros de pesquisa e inovação etc. Dessa maneira, cada área tende a acolher e a combinar de um modo a história das técnicas e a forma como podem ser implantadas e pensadas no uso do território.

Os objetos técnicos implantados no território, como a instalação de fibras ópticas, confirmam, nessa perspectiva, o domínio econômico e político de determinados locais, acompanhados obviamente pela ação espacial e estratégica de certos agentes e corporações. Esse processo tende a ser seguido, geralmente, de inovações e invenções no território que mudam a forma como a sociedade concebe uma ideia ou cria um aparelho técnico que revoluciona parte do setor produtivo. Consequentemente, as invenções, inovações e máquinas tenderão a ser motor principal das transformações na sociedade, sendo que os objetos são componentes da técnica na sua mediação com o meio, por meio do trabalho, da transformação da natureza de uma dada formação socioespacial.

Lugares, países e regiões passam a se diferenciar espacialmente uns dos outros, não somente pela localização absoluta, mas por possuírem conteúdos diferenciados da técnica e por estarem vinculados a conteúdos específicos da ciência e da informação na atualidade, como demonstrou Milton Santos em vários de seus trabalhos.

Nessa interpretação, afirma-se que o conceito de espaço é trabalhado de diferentes formas por Milton Santos como conjunto de fixos e fluxos (Santos, 1978); configuração territorial e relações sociais (Santos, 1988); bem como indissociável relação de sistema de objetos e ações (Santos, 1996). Da leitura dessas obras constata-se que quando se adiciona ciência na reconstrução do espaço se potencializa o desenvolvimento de tecnologia, na constante agregação de saber ao trabalho e às demais dimensões da vida social.

Tal efeito acaba por trazer como resultado novas revoluções no modo de produzir e na forma como a sociedade se relaciona com a natureza e edifica a expansão da urbanização e da industrialização, por 
meio do avanço da técnica. Ao adicionar a informação a esse quadro, segundo Santos, se pode referenciar na expressão do meio técnico-científico-informacional. Tal termo só poderá ser empregado com maior ênfase no movimento posterior à Segunda Guerra Mundial, possibilitando a conexão dos lugares, por meio da informação e da formação de novas redes técnicas das telecomunicações, na produção de uma nova sociedade e de um novo período da técnica.

Nesse caso, é da publicidade que avança o elemento difusor e unificador do pensamento informacional, associando-se às imagens na produção de uma diferenciada compreensão universal. Mas é por meio das telecomunicações que se emana e difunde uma nova forma técnica de se mandar, produzir e influenciar espacialmente, como considerou Milton Santos e María Laura Silveira ao relatarem que:

A revolução das telecomunicações, iniciada no Brasil dos anos 70, foi um marco no processo de reticulação do território. Novos recortes espaciais, estruturados a partir de forças centrípetas e centrífugas decorriam de uma nova ordem, de uma divisão territorial do trabalho em processo de realização. Do telégrafo ao telefone e ao telex, do fax e do computador ao satélite, à fibra óptica e a Internet, o desenvolvimento das telecomunicações participou vigorosamente do jogo entre separação material das atividades e unificação organizacional dos comandos. (Santos; Silveira, 2006, p.73)

Desta maneira, os lugares possuem diferentes manifestações desse processo, podendo ser "obedientes" ou "desobedientes" nessa lógica de reprodução do capital e das transformações socioespaciais. As modernizações definem o meio de forma distinta e possuem uma articulação centro-periferia expressiva, na qual os centros de inovação irradiam tecnologia e as difundem pelas demais partes do território. Nesse cenário:

Os lugares estão presentes nos meios de comunicação e estes também se fazem presentes, de modo material e concreto, em seus lugares de ocorrência. Portanto, embora paradoxal, o "virtual" se 
localiza no espaço, se espacializa em momentos e lugares específicos. (Serpa, 2011, p.16)

Com isso, questionando fronteiras, as telecomunicações demonstram um problema bastante pertinente à Geografia: a temática das continuidades e descontinuidades e que se traduzem, grosso modo, nas camadas de usos, serviços e infraestrutura das tecnologias da informação. Novas redes informacionais podem ser inseridas espacialmente, transgredindo territórios e reorganizando dispositivos existentes de comando, implantando novas formas de reprodução do capital, como é o caso de citar o teletrabalho (trabalho à distância, trabalho remoto) e seus usos variantes, na economia flexível.

As telecomunicações têm, nesse universo, um papel ativo nas transformações socioespaciais vividas mundialmente que ultrapassam noções clássicas dos velhos esquemas espaciais, em forma de arquipélagos e de baixa conexão e integração, traduzindo-se, grosso modo, na arquitetura de uma "sociedade em rede".

Tais transformações incidem direta e indiretamente na cidade e no campo, no trabalho, nas finanças e no meio técnico-científico-informacional, em escala ampla e particular, na produção dialética do desenvolvimento desigual e combinado, refletindo-se no movimento de diferenciação geográfica entre locais, regiões, estados e no cenário da mundialização.

Por sua vez, essas mudanças estão intimamente relacionadas à informacionalização da economia e aos impactos de uma sociedade que promove e integra as tecnologias da informação, como elemento difusor dos serviços de telecomunicações.

Ademais, vale frisar que tais observações não podem ser entendidas como um ponto conclusivo para essas discussões. Essas, por sua vez, somam-se a outras transformações socioespaciais, em diferentes períodos, produzidas no movimento em espiral da sociedade e animadas pelo motor histórico da luta de classes, no modo de produção hegemônico capitalista, lembrando que muitos autores, ao se referirem sobre o tema, realizam uma abordagem sobre este 
de forma compartimentalizada, como já alertaram Dicken e Malmberg (2001, p.345) quando afirmaram que:

Much economic geography research asks questions about the role of space and place in shaping the transformation of economic activity systems and about the impact of such transformations on the wider processes of territorial development at local, regional, national, and global scales. Typically, however, such analyses tend to be compartmentalized, focusing either on a specific activity system or on a specific territory, rather than on the relationships between them. It is extraordinarily difficult to conceptualize economic activity systems and territorially defined economies simultaneously.

Algumas das transformações contemporâneas foram exploradas teoricamente de modo global por Jurado da Silva (2011, p.69 e 70) e em estudo particularizado por Sposito e Jurado da Silva (2013) e aqui são retomadas e expandidas para explicação do contexto atual, como é demonstrado no Quadro 3, que procura sintetizar tais transformações à luz da Geografia.

Pode-se afirmar, portanto, que as transformações têm repercussão direta na produção e aceleração da criação de tecnologias da informação que representam o avanço da técnica e de uma história de revoluções científicas que ainda se encontra em andamento. Com isso, compreende-se que aprender tal movimento é uma tarefa árdua no momento em que são postos novos desafios analíticos e tecnológicos aos investigadores do tema.

Por fim, cabe frisar que essas inovações têm íntima relação com a forma como a sociedade se apropria das diferentes evoluções técnicas e as aplica no contexto de ciclos ascendentes da economia, possibilitando, posteriormente, a edificação de redes técnicas que são implantadas territorialmente e auxiliam no processo de comunicação da informação, como será descrito no item subsequente. 


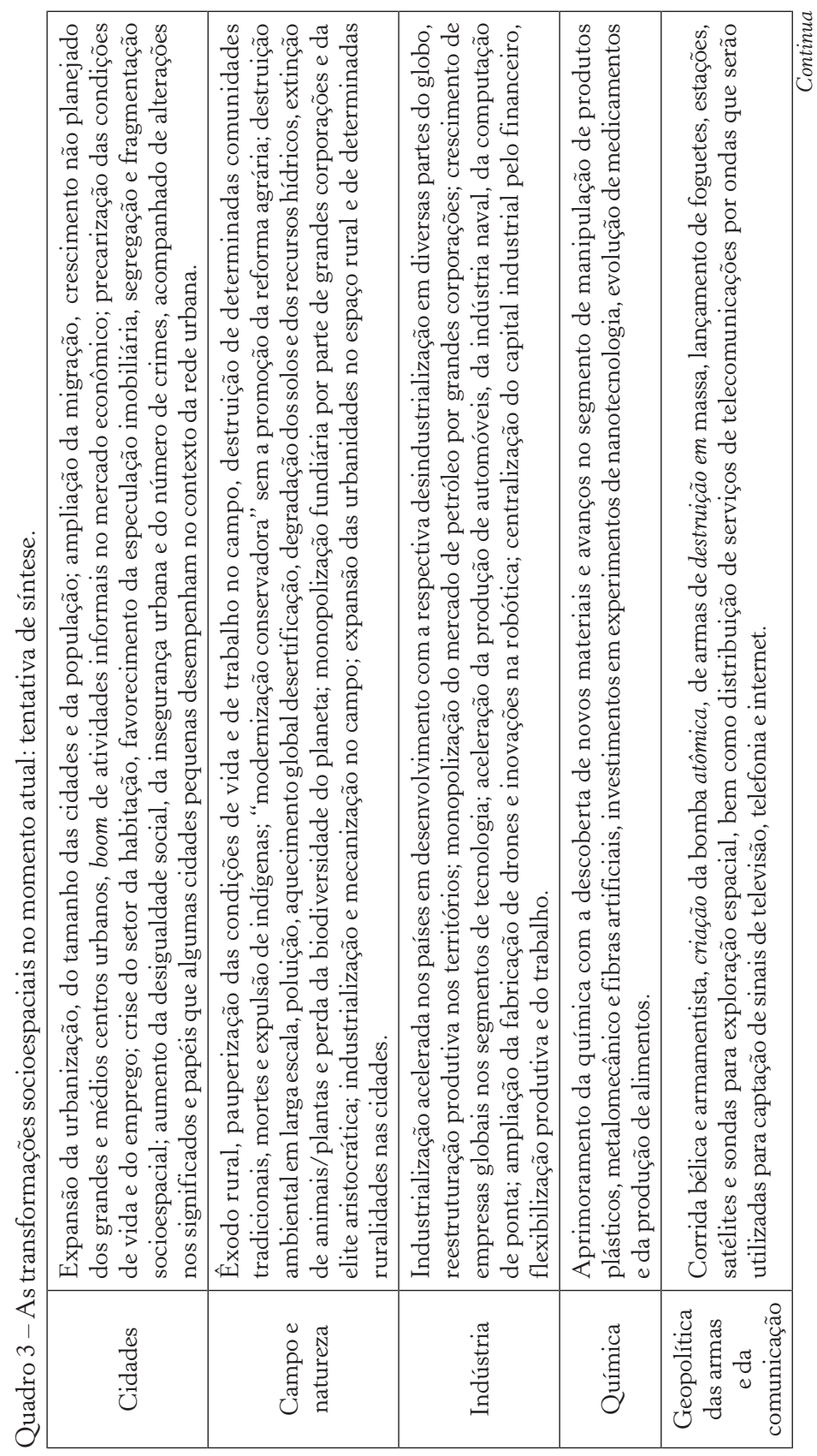




\begin{tabular}{|c|c|c|c|c|c|}
\hline & 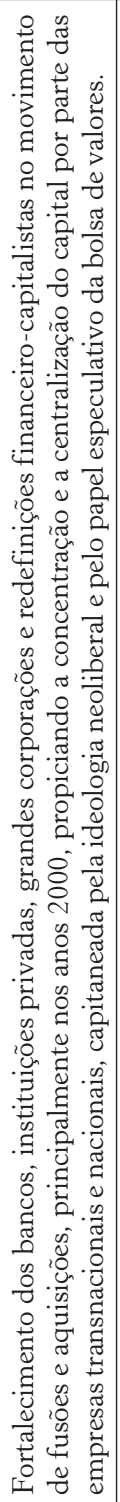 & 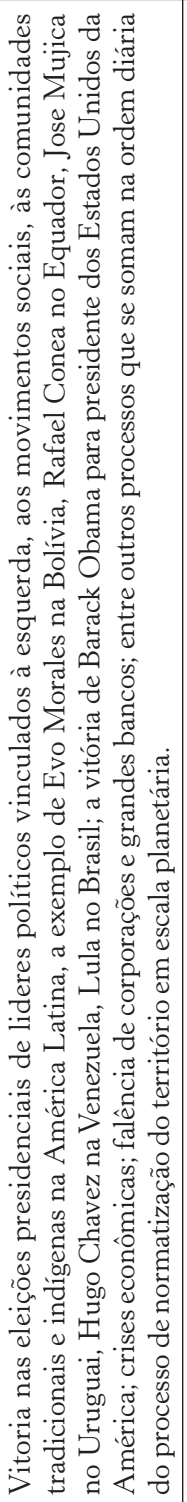 & 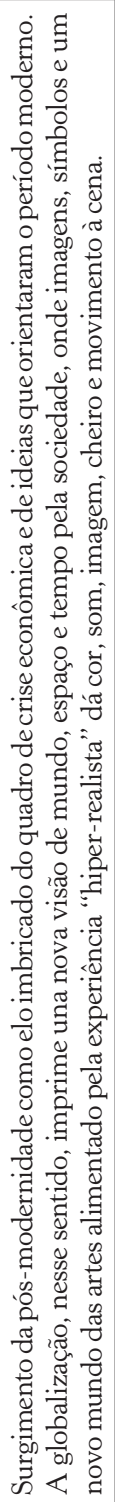 & 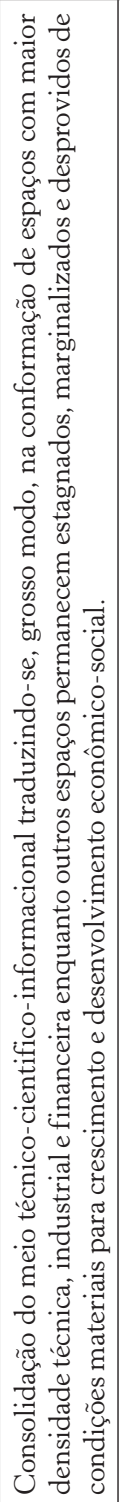 & 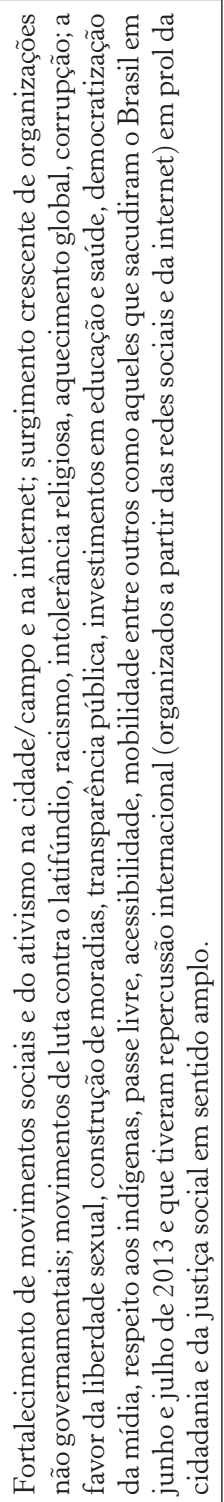 \\
\hline 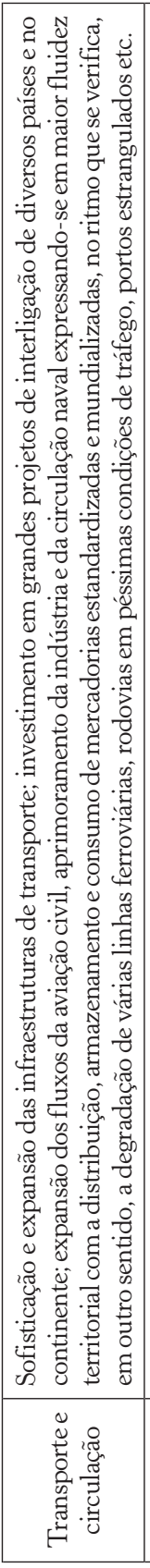 & 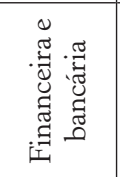 & & & -10 & $\sum^{0}$ ๘ \\
\hline
\end{tabular}




\section{As tecnologias da informação como inovações, o uso do território e as redes técnicas}

Vivemos um momento ímpar, no qual a sociedade é capaz de se conectar e se integrar em um verdadeiro movimento informacional, graças obviamente aos avanços da técnica no segmento das telecomunicações. Nunca antes o homem foi capaz de transmitir mensagens e de recebê-las de modo tão rápido e eficaz como hoje. Este processo, contudo, foi contraditório, lento e gradual, desigual e combinado, reprodutor de cópias e inovador.

Pode-se considerar que "O século XX conheceu uma aceleração do ritmo da inovação em vários campos, particularmente no das telecomunicações [...]" (Dias, 1996, p.115). Antes, poderia até se afirmar que determinadas inovações fossem produzidas por mentes individuais, mas hoje o cenário é outro. As invenções são cada vez mais elaboradas em escritórios de gigantes da tecnologia, sediados em grandes metrópoles do mundo.

Nesse sentido, por invenção compreende-se a geração de uma determinada tecnologia, processo ou objeto técnico, resultante do trabalho humano. Não significa diretamente descoberta, embora possa ser acompanhada desta. Do passado, citam-se grandes inventores e desenvolvedores notáveis de objetos técnicos como Charles Wheatstone e Samuel Morse responsáveis pelo desenvolvimento do telégrafo, Alexander Graham Bell pelo telefone, Edwin Armstrong e Lee de Forest pelo rádio, John Logie Baird e Philo Fanrsworth pela televisão.

Essas foram verdadeiras invenções que se traduziram em inovações e que acabaram por transformar a sociedade, cunhando posteriormente a ideia de uma "era informacional", no momento contemporâneo; implicando, por outro lado, em uma revolução na forma de se comunicar e de se transmitir mensagens, códigos e símbolos entre pessoas e instituições. Como argumentou Santos (1979, p.34), "[...] não há inovação sem invenção, da mesma forma como não há técnica sem tecnologias." 
Sendo assim, Schumpeter (1982) tem sido um dos autores mais utilizados para a interpretação da inovação e para o entendimento do caráter cíclico da economia. Tal autor afirmava que: "O remédio mais importante à la longue, e o único que não está sujeito à nenhuma objeção, é o aperfeiçoamento do prognóstico do ciclo econômico [...]" (Schumpeter, 1982, p.166). Além disso, é preciso ter em vista que:

Schumpeterian thought is characterized by a series of dichotomies: between the realm of science from which invention springs and the workaday world of industry [...] between large and small firms, and so forth [...]. (Storper, Walker, 1989, p.100)

$\mathrm{Na}$ interpretação schumpeteriana, a criação de um produto ou uma invenção qualquer não significa necessariamente inovação, mas é a sua aplicação e sua repercussão na sociedade que as tornam uma inovação. Ou seja, uma renovação no modo de conceber uma ideia, podendo haver não somente inovação, em termos de produto, mas também de mercados, ações gerenciais, organização produtiva etc.

Dessa forma, inovações e invenções são postas no mercado em fase ascendente ao longo dos ciclos da economia, gerando um efeito de aumento da demanda e da ampliação comercial, abertura de novos negócios e ampliação do capital, no processo de "destruição criativa" (expressão de Schumpeter).

Já Dicken (1998, p.146 e 147), baseando-se em Freeman e Perez (1988), considerou que há 4 tipos de mudança tecnológica e inovação, a saber:

I) Inovações incrementais: referem-se à pequena escala, com alterações mais leves em produtos e processos;

II) Inovações radicais: transformam radicalmente produtos ou processos;

III) Mudanças de sistema de tecnologias: são combinações de inovações incrementais com radicais, aliadas as inovações organizacionais e administrativas e que possuem relação com setores como tecnologia da informação, biotecnologia, materiais de tecnologia, energética e espacial; 
IV) Mudanças de paradigma técnico e econômico: são alterações de larga escala que revolucionam a sociedade, em que: "the 'creative gales of destruction' that are the heart of shumpeter's long wave. They represent those new technology systems wich have such pervasive effects on the economy as a whole that they change the 'style' of production and management throughout the system [...]” (Freeman, 1987, p.130 apud Dicken, 1998, p.147).

Nesse sentido, é preciso ressaltar que: "The notions that global economic growth occurs in a series of long waves of more or less fifty years duration is generally associated with the work of the Russian economist N. D. Kondratiev in the 1920 [...]" (Dicken, 1998, p.147).

Há, portanto, uma história cíclica da economia, na qual a ampliação das inovações e invenções é visualizada, sobretudo, na fase ascendente. Por outro lado, é preciso destacar que determinadas inovações ocorrem em outros momentos da história econômica e que, muitas vezes, algumas dessas inovações são representadas a partir da ideia de degraus por alguns autores, em que cada inovação leva a outra (em vez da noção cíclica).

As revoluções nas telecomunicações estão presentes no último grande ciclo da economia e são acompanhadas por investimentos na robotização e na biotecnologia, constituindo o quarto Kondratieff ${ }^{3}$. Conforme Penna Filho (2009, p.7):

Os "ciclos tecnológicos" por mais radicais que sejam entre si, não são totalmente independentes. Eles guardam entre si uma relação de causalidade, de interesse e necessidade evolutiva, que motiva a criatividade, desperta a imaginação e torna a experiência obtida um valioso ativo.

3 Tal autor comparece na literatura como Nikolai Dimitrievich Kondratiev, traduzido do russo Николай Дмитриевич Кондратьев, е em algumas traduções seu último sobrenome é escrito como Kondratieff. Neste livro, a preferência é pela expressão Kondratieff. 
Analisando-se ciclicamente a economia e o lançamento de determinadas inovações verifica-se até hoje quatro ciclos bem definidos na história e um em processo. De acordo com Silveira (2003, p.43) pode-se destacar que:

[...] as inovações tecnológicas relevantes no primeiro ciclo foram a metalurgia do ferro, a máquina e fiar e tecer, a evolução da máquina ferramenta e a máquina a vapor; no segundo ciclo foram a aplicação da máquina a vapor nos transportes (ferrovias e na navegação) e o processo Bessemer de fabricação de aço; no terceiro ciclo foram a eletricidade, a indústria química e de materiais sintéticos, a linha de montagem (sistema fordista de produção) e o automóvel com motor a combustão; no quarto ciclo foram a petroquímica, a aeronáutica, as pesquisas nucleares, as telecomunicações e as inovações na indústria automobilística. Segundo Egler (1994), para os neo-schumpeterianos, o quinto ciclo será composto pelas inovações na microeletrônica, informática e telecomunicações (telemática), biotecnologia e os novos materiais. Todos esses acontecimentos levariam/levam a uma terceira revolução técnico-científica e também informacional.

Consequentemente, tais transformações têm repercussão direta na produção e aceleração da criação de tecnologias da informação que representam o avanço da técnica e de uma história de revoluções científicas que ainda se encontra em andamento. Com isso, compreende-se que aprender tal movimento é uma tarefa árdua no momento em que são postos novos desafios analíticos e tecnológicos aos investigadores do tema. Assim, o escrito de Silveira (2003) têm pontos de consenso com outros autores, a exemplo de Dicken (1998), quando escreveu que: "The fifth Kondratiev cycle, wich appears to have begun in the 1980s and 1990s, is associated primarily with the first of the five 'generic' technologies referred to above: information technology (IT)” (Dicken, 1998, p.149).

Dessa maneira, as tecnologias da informação representam verdadeiras inovações na forma de conceber a sociedade e o capitalis- 
mo contemporâneo, possibilitando que velhas hierarquias espaciais sejam colocadas em novo patamar e até mesmo superadas pela interação espacial de múltiplos contatos, numa economia cada vez mais integrada globalmente.

Assim, Sposito (1999), por exemplo, ressaltou que a sociedade atual vive um período técnico alicerçado pelo papel das tecnologias da informação, no qual a globalização, a mundialização e a internacionalização do capital são processos imbricados no desenvolvimento econômico dos países. Contudo, tais transformações se fazem assentadas especialmente em [...] revoluções logísticas porque elas são decorrentes de incorporação das tecnologias aos transportes; necessidades de se aumentar a velocidade nos fluxos de capitais e na circulação das informações" (Sposito, 1999, p.105).

Além disso, a revolução logística atual só pôde ocorrer quando houve uma maior associação entre o Estado e as empresas que estão relacionadas, evidentemente, aos movimentos de crescimento econômico e, com isso: "Essa revolução logística corresponde às fases de crescimento e consolidação do capitalismo associados aos ciclos de crise e expansão os três Kondratieff [...]” (Sposito, 1999, p.107).

Ademais, na revolução atual, está presente de forma cada vez mais marcante o capital financeiro, a tendência à homogeneização, à seletividade, à criação tecnológica, ao estímulo à competitividade, à verticalização nas relações de produção e, por fim, à superação do Estado (Sposito, 1999, p.101-103). Nesse contexto, nasce o: “[...] Estado voltado fundamentalmente para as determinações do capital, sem pátria nem proprietários particulares, apenas proprietários privados identificados pelas relações de papéis [...]" (Sposito, 1999, p.103). Por conseguinte, as empresas estão cada vez mais fortes e governam cada vez mais.

As empresas muitas vezes deixam de ser "nacionais" para se somarem ao capital estrangeiro, em grandes sociedades anônimas, com o capital pulverizado em ações, nas bolsas de valores. Não se fala mais de capital nacional ou estrangeiro puro e simplesmente, mas de um controle acionário que é exercido por determinado ente ou grupo no comando corporativo do uso do território, como será 
destacado, mais adiante, no caso das telecomunicações no Brasil pós-privatização.

Além disso, é com base na compreensão do período atual da economia que se baseia a periodização mais geral do trabalho, na qual a informação se torna o elemento essencial de conexão da economia, alicerçado pelo desenvolvimento das "redes de serviço e suporte" (Curien; Gensollen, 1985) das telecomunicações, sobretudo, a partir de 1973, com o final da fase expansiva do capital e o término dos chamados "Trinta Anos Gloriosos" de crescimento econômico. Isso significou não somente o início da crise do petróleo com a alta dos preços dessa commodity, mas inaugurou uma nova fase depressiva na economia. Já a definição da periodização direta e mais objetiva fundamenta-se, especialmente, no contexto pós- privatização das telecomunicações no Brasil, ou seja, a partir da década de 1990 e que se estende até aos dias atuais.

Assim, vale ressaltar sobre o assunto que:

As famílias das técnicas emergentes com o fim do século XX combinando informática e eletrônica, sobretudo - oferecem a possibilidade de superação do imperativo da tecnologia hegemônica e paralelamente a proliferação de novos arranjos, com a retomada da criatividade [...]. (Santos, 2001, p.165)

Entretanto, é preciso que não se perca a dimensão da história e de seu significado, visto que não é possível avaliar o papel das inovações e invenções de modo mais adequado sem levar em conta a análise dos ciclos econômicos, promovidos durante o desenvolvimento da humanidade, no uso do território.

Na década de 1970, o Brasil ainda detinha o controle estatal no setor das telecomunicações. Já nos anos 1990, o país passou a adotar um uso corporativo privado do território, trazendo novos elementos para a compreensão desse fenômeno. Por conseguinte, a argumentação central dessa pesquisa terá como panorama principal o período pós-privatização do setor, com a ação e a estratégia das grandes corporações internacionais e nacionais no uso do território, 
isto é, mais precisamente a partir do governo de Fernando Henrique Cardoso.

Portanto, o presente trabalho centrará seus esforços no sentido de compreender a telefonia celular, televisão por assinatura e internet como invenções e inovações na história da econômica da sociedade. Tais eventos da técnica devem ser visualizados por meio dos impactos que causaram na forma da sociedade se comunicar e transmitir mensagens.

O telégrafo foi o instrumento precursor que inaugurou a era da revolução informacional no mundo (Gras, 2003). Já hoje: “Chegamos a um outro século e o homem, por meio dos avanços da ciência, produz um sistema de técnicas presidido pelas técnicas da informação" (Santos, 2001, p.142). Com isso, somam-se ao telégrafo, diversas e modernas tecnologias que auxiliam a sociedade a se tornar cada vez mais informacional.

Essa evolução não foi linear e conta com diversos avanços que foram sendo somados, ao longo do tempo, na inter-relação entre ciência e tecnologia na produção e difusão da informação em sentido espacial. Consequentemente, com a invenção do telégrafo, as informações podiam, a partir de então, serem difundidas por conexão de fio, ligando um sistema de pontos. Ferrari (1991) ao abordar sobre o assunto da evolução do segmento considerou que:

[...] As telecomunicações se iniciaram verdadeiramente em 1844, quando SAMUEL MORSE transmitiu a primeira mensagem em uma linha entre Washington e Baltimore. Estava inventado o TELÉGRAFO! Neste processo cada letra foi codificada por uma combinação de sinais longos e breves (Código MORSE). (Ferrari, 1991, p.1, grifo do autor)

Nesse contexto, o código Morse constituído por um sistema de pontos e traços para comunicação foi largamente empregado no telégrafo e sua patente registrada em nome de Samuel Morse, nos Estados Unidos. Na França, também houve a contribuição de Jean Maurice Émile Baudot, que elaborou um método de organização 
das mensagens por meio de vários canais (Beauchamp, 2001). De acordo com Beauchamp (2001, p.390), por exemplo:

On Continental Europe new methods were being applied, and the Baudot system was being installed by the French authorities to operate the London-Paris triple duplex circuits at a cumulative rate of $180 \mathrm{wpm}$ for the six $30 \mathrm{wmp}$ channels in service. It was the consistently good performance of this circuit that led the Postmaster General in 1913 to institute a far-reaching inquiry into high-speed telegraph operation.

Entretanto, cabe a ressalva de que a utilização desse equipamento não ficou restrita somente aos Estados Unidos e à França, mas foi bastante difundida no mundo, especialmente no século XIX. No caso brasileiro, houve a instalação desse sistema em algumas partes do território, assegurando a comunicação integrada a áreas até então pouco povoadas (Dias, 1995). Nessa perspectiva, vale frisar conforme Santos e Silveira (2006) que: "[...] O telégrafo, inovação presente no Brasil desde 1852, ganha enorme difusão, sobretudo a partir das expedições do Marechal Rondon [...]" (Santos; Silveira, 2006, p.39).

Marechal Cândido Rondon foi responsável por conectar grande parte do interior do território nacional, instalando sistemas telegráficos na região Norte e Centro-Oeste do país (Aranha, 2010). Sendo assim, ao longo da sua trajetória no exército brasileiro, construiu diversas linhas telegráficas. À medida que ia alcançando determinadas áreas, favorecia a colonização do interior com a criação de estradas e ferrovias (dentre elas a estrada de ferro Madeira Mamoré, ligando Porto Velho a Guajará-Mirim), a exemplo do que foi feito no atual Estado de Rondônia e que igualmente lhe presta tributo com seu nome.

O invento da telegrafia, no entanto, foi sendo paulatinamente superado pela criação do telefone, no século XIX, na evolução da técnica e da inovação. $\mathrm{O}$ telefone foi projetado originalmente para transmitir sons por meio de sinais elétricos, possibilitando a trans- 
formação de energia acústica em elétrica no ponto transmissor, sendo o seu maior objetivo difundir a informação ao propiciar que as pessoas falassem e ouvissem por meio da conexão estabelecida por ele (Ferrari, 1991).

Tal equipamento foi patenteado pelo inventor Alexander Bell (Ferrari, 1991) quando conseguiu se comunicar de um cômodo a outro de uma oficina de experimentos com Thomas Watson. Mais tarde, o invento também era exposto no centenário da Filadélfia, nos Estados Unidos, de onde podia ser apreciado e depois implantado, em outras partes do território.

As primeiras chamadas telefônicas ocorriam por corrente de toque e o usuário tinha que acionar a telefonista para que sua chamada fosse processada. Paulatinamente, isso foi sendo mudado, adotando-se centrais automáticas para uso e telefones que possuíam discos para efetuar a ligação. As inovações não pararam por aí e década após década novos recursos e materiais foram sendo utilizados.

Foi somente em meados do século XX, porém, que o primeiro aparelho de telefonia móvel no mundo que não usava fios foi lançado, por meio dos esforços da Motorola. Foi a empresa Bell Labs (concorrente da Motorola), no entanto, a responsável por lançar o primeiro celular. Nesse sentido, Couto (2007, p.4) esclareceu que:

[... e em 1973 dois pesquisadores de laboratórios diferentes faziam à mesma pesquisa em telefonia móvel. Se por um lado Martin Cooper, da Motorola, pesquisava o telefone celular, por outro lado Joel Engel, do laboratório rival Bell Labs, perseguia o mesmo objetivo, tanto que, utilizando um aparelho dynatac, Cooper conversou com Engel no que poderá ser chamado de a gênese da telefonia móvel.

Assim, em termos socioespaciais, a telefonia móvel possibilita acessar indivíduos no espaço e não associar o telefone a um local específico de chamada e recepção como ocorre com a telefonia fixa. Fala-se, portanto, de localização de pessoas e não de conexão de locais. As pessoas se tornam entidades espaciais e podem ser ge- 
ograficamente localizadas. Com isso, o local de cobertura da rede móvel é organizado em células de propagação.

Os primeiros aparelhos de telefonia celular chegavam a ter um peso e dimensões razoáveis. Os preços praticados para este tipo de serviço também eram caros e poucas pessoas tinham acesso a essa novidade, que acabou por se popularizar somente nas décadas de 1980 e 1990, dependendo do país. No caso brasileiro, por exemplo, essa invenção só teve maior repercussão nos anos 2000.

$\mathrm{Na}$ literatura sobre o tema, verifica-se que a evolução desse invento passou por substanciais transformações, o que implica gerações distintas de equipamentos e tecnologias que ficaram mundialmente conhecidas como $2 \mathrm{G}, 2,5 \mathrm{G}, 3 \mathrm{Ge}$, mais recentemente, as tecnologias 4G e 5G. Cada geração de telefonia celular possibilitou uma série de inovações diferenciais, nos equipamentos e na forma de se comunicar (Mantovani, 2006).

Hoje, os aparelhos se tornaram uma espécie de microcomputador portátil com tela sensível ao toque, contam bluetooth e wi-fi, permitem reprodução e composição de músicas em diversos formatos, fazem a recepção de estações de rádio e de canais de televisão, além de contarem com internet, GPS (Global Position System), câmeras de vídeo, entre outras novidades que são lançadas por diversas corporações a exemplo da estadunidense Apple e da sul-coreana Samsung. Esse movimento possibilitou, paulatinamente, a integração de diferentes mídias em único equipamento e permitiram ao indivíduo ficar online durante toda hora (se desejar e tiver condições financeiras e técnicas para isso), em uma evolução crescente de novos gadgets.

Esse caminho de desenvolvimento da telefonia e das tecnologias da comunicação não foi linear e se deve, em partes, a evoluções anteriores, a exemplo da criação do rádio e da televisão.

Já o rádio, nascido no século XIX, é considerado como um sistema de comunicação por ondas eletromagnéticas no espaço, que pode captar ondas curtas e longas, sendo as primeiras de alta frequência e as últimas de baixa. Sobre o assunto Ferrari (1991, p.3) 
auxiliou no entendimento da evolução dessa invenção quando escreveu que:

[... em 1886 HEINRICH HERTZ provou experimentalmente, a analogia entre ondas de luz e elétricas. Mais tarde GUGLIERMO MARCONI, usando os fundamentos de JAMES MAXWELL e de HERTZ, construiu o primeiro transmissor de rádio (1895), efetuando demonstrações públicas na Inglaterra (1896), e nos Estados Unidos (1899) transmitiu por rádio os boletins da corrida American Cup.

Nesse sentido, é preciso atentar para o fato de que o rádio possibilita, por meio de seu circuito, a transferência de energia e, por conseguinte, da informação. Jaroslav (1987, p.1987) descreveu sobre esse processo que:

Na transmissão espacial das ondas de rádio, ondas eletromagnéticas, utilizam-se antenas para transferir energia de um circuito ao espaço, e do espaço para um circuito. A antena transmissora ou radiadora, e a antena receptora são basicamente iguais.

Diferentemente do telefone e do telégrafo, que se apoiaram inicialmente no sistema de transmissão de informação por fios e cabos, o rádio inaugura as transmissões de informações por ondas, o que representou um avanço gigante no segmento das telecomunicações.

No Brasil, a primeira transmissão de rádio ocorreu, segundo Saroldi e Moreira (2005, p.15 e 16) na data de 7 de setembro de 1922, no evento de comemoração da Independência do Brasil, em um discurso do presidente Epitácio Pessoa, no Rio de Janeiro, e transmitida para receptores em São Paulo, Petrópolis e Niterói. Para esses autores:

Ainda que a recepção fosse imperfeita, cheia de ruídos, não foi uma experiência inconsequente. Cerca de sete meses depois, em 20 de abril, o médico e antropólogo Edgard Roquette-Pinto e o 
astrônomo Henrique Morize assinavam a ata da fundação da Rádio Sociedade do Rio de Janeiro [...]. (Saroldi; Moreira, 2005, p.16)No espaço circula, portanto, informação e energia que são acompanhadas, logicamente, pela comunicação de mensagens, ordens e comandos. Tal relação é ampliada cada vez mais pelo lançamento de satélites e aprimoramento da técnica nas comunicações, sendo ainda utilizada pela telefonia celular, internet e televisão. Nesse sentido, compreende-se que as "[...] Ondas de rádio, comunicação via satélite e sistema óptico de transporte constituem as variações técnicas básicas para a transmissão de sinais à distância”. (Gomes, 2006, p.346)

A televisão, nesse quadro, foi outra inovação no modo de se comunicar, porque possibilitou a superação do rádio ao captar ondas eletromagnéticas e reproduzir transmissões com vídeo e voz. Nos primeiros aparelhos de televisão a imagem era em preto e branco com sinal analógico e depois a tecnologia foi sendo alterada com a adição do padrão colorido. Hoje, os sinais podem ser transmitidos de modo digital, aumentando a qualidade de imagem e som dos aparelhos televisores.

A criação e evolução da televisão foram acompanhadas ainda por diferentes sistemas de transmissão e acesso à informação. Com isso, surge a televisão paga ou TV por assinatura que é diferente da televisão aberta por apresentar, em geral, melhor qualidade de som e imagem, além de dispor de uma gama mais abrangente de canais e informação, cobrando certo preço pelo seu acesso.

A televisão paga foi implantada inicialmente nos Estados Unidos. Sobre o assunto, Ramos e Martins (1995, p.140) escreveram que:

A Televisão por Assinatura, na forma de TV a Cabo, surgiu no fim da década de 1940, nos Estados Unidos, como uma solução técnica para melhorar a qualidade na recepção dos sinais radioelétricos de TV, prejudicada por interferências, sobretudo, em regiões montanhosas. A solução era bem simples: em uma colina instalava-se uma grande antena que captava os sinais televisivos das emissoras 
convencionais, dirigindo-os a uma pequena estação que ampliava e corrigia suas distorções. A esta estação se ligava um cabo que distribuía os sinais às residências de uma dada comunidade. Por isso, recebeu, na época, a denominação "Community Antenna Television”, ou CATV, ainda hoje utilizada.

No Brasil, o serviço de TV paga teve início no final da década de 1980, com a transmissão de conteúdo da CNN, MTV, entre outras (ABTA, 2012). Mas, somente na década de 1990 é que se teve início as primeiras concessões de TVs brasileiras dessa modalidade. Segundo a Associação Brasileira de Televisão por Assinatura (ABTA) foi em 1991 que:

[...] grandes grupos de comunicação ingressaram no setor, investindo alto em novas tecnologias. O pioneirismo coube às Organizações Globo, que desenvolveram a Globosat, além do Grupo Abril, que criou a TVA. Em seguida outros importantes grupos, como RBS e Grupo Algar, também entraram forte no mercado. ${ }^{4}$

É claro que as evoluções nesse segmento não param por aí e hoje as empresas investem cada vez mais em interatividade e na reprodução de som e imagem de qualidade no padrão high-definition (HD) e também em 3D. Entretanto, é preciso ter em vista que das tecnologias e inovações expostas nenhuma causou tanto impacto na sociedade como aquela promovida pela internet. Esta, por sua vez "[...] nasceu da improvável intersecção da Big Science, da pesquisa militar e da cultura libertária [...]" (Castells, 2003, p.19).

Pode-se afirmar, portanto, que se encontra em curso uma verdadeira revolução na maneira como a sociedade se comunica. Isso tem repercussões importantes nas relações cotidianas entre as pessoas, no mundo do trabalho, nas finanças, no lazer, no comércio, no consumo, na religião, na política etc. Enfim, seria difícil apontar um segmento que não tenha passado por um processo de trans-

4 (Disponível em: <www.abta.org.br/historico.asp>. Acesso em: 21 set. 2015) 
formação em razão do fenômeno da internet e das inovações nas telecomunicações e, portanto:

[...] a Internet tem uma geografia própria, uma geografia feita de redes e nós que processam fluxos de informação gerados e administrados a partir de lugares. Como a unidade é a rede, a arquitetura e a dinâmica de múltiplas redes de computadores e a dinâmica de múltiplas redes são as fontes de significado e função para cada lugar. O espaço de fluxos resultante é uma nova forma de espaço, característico da Era da Informação, mas não é desprovida de lugar: conecta lugares por redes de computadores telecomunicados e sistemas de transporte computadorizados [...]. (Castells, 2003, p.170)

Ao conectar diferentes lugares simultaneamente a internet possibilitou o rompimento de barreiras físicas. Isso, em geral, tem sido feito pelas mais variadas tecnologias, como as do segmento sem fio (por ondas), via-rádio, telefônica, fibra óptica e outros objetos técnicos que inovam o sentido de sua difusão em sentido histórico. Esse processo, no entanto, não se deu de maneira acelerada, visto que durante muito tempo a internet ficou restrita aos círculos militares estadunidenses e depois a alguns centros de pesquisa e universidades para, só mais tarde, ser comercializada e acessada pela população.

Bernardes (2012, p.134) escreveu que a internet foi:

Desenvolvida a partir de um projeto de uma agência estadunidense chamada ARPA (Advanced Research and Projects Agency), a Internet surge como desenvolvimento de uma rede de computadores que ligavam quatro centros de pesquisas universitários, denominada ARPANET. Por este processo, em meados da década de 1970, se desenvolveu aquilo que ainda é a base da Internet atual, ou seja, o protocolo TCP/IP (Transmission Control Protocol/Internet Protocol), o qual é o endereço de um determinado computador conectado a rede, o que permite ao internauta a transferência de dados. 
Ainda de acordo com Bernardes (2012, p.174), por volta da década de 1980, a Arpanet já passava por um processo de expansão ligando-se aos computadores da NSF (National Science Foundation) e de outras empresas como a IBM. Da desativação do backbone ${ }^{5}$ construído pela Arpanet, em 1990, iniciaram-se as atividades do backbone DRI (Defense Research Internet), além de, nessa década, ter colocado em curso a operação do Ebone europeu e a ANS (Advanced Network Services), elaborando-se o novo backbone e o principal da estrutura de redes da internet (Bernardes, 2012, p.174).

Segundo Pires (2005), no Brasil, a internet só teve seu funcionamento a partir do final da década de 1980, por iniciativa da Fapesp, da Universidade Federal Fluminense e do LNC (Laboratório Nacional de Computação Científica). Mas, foi por meio da instalação da Rede Nacional de Pesquisa (RNP) do Ministério da Ciência e Tecnologia, que foi implantado o backbone que possibilitaria a conexão com várias capitais brasileiras, por meio dos chamados POPs (Point of Presence), fazendo com que outros troncos de conexões regionais fossem construídos (Pires, 2005).

Para Goemann (2005, p.32 e 33), a liberação para exploração comercial se deu a partir de 1995 com o governo Fernando Henrique Cardoso, em portaria do Ministério das Comunicações e do Ministério de Ciência e Tecnologia, permitindo a existência de provedores comerciais. Nesse momento, são criados os principais provedores de internet que atuariam no país, isto é, o:

[...] Universo Online (UOL), o mais antigo, criado em 1995, IG, Terra e Globo, que reúnem cerca de 11 milhões de usuários ocupam cada vez mais espaço, não só como produtores de conteúdo, mas como distribuidores [...]. (Dias; Cornils, 2008, p.145)

5 "Segundo Malecki (apud Tranos \& Gillespie, 2009), as redes backbones são definidas como sistemas autônomos que constituem o núcleo da Internet, essenciais para todas as interações entre computadores, exceto as locais" (Motta, 2012, p.23). 
A internet tem no universo atual, portanto, papel fundamental e, nesses termos, participa no Brasil de uma densa estrutura técnica e informacional que envolve uma ampla rede privada e pública de backbones. Assim, dominar o processo de suporte e produção da informação por meio da rede da internet, por exemplo, é uma condição essencial tanto para corporações privadas quanto para o estado no uso do território. Com isso, a informação, enquanto movimento de revolução, causa novo significado ao espaço e acirra as forças envolvidas no território usado.

Nessa concepção, o território usado, produzido historicamente, contempla a relação de múltiplas estratégias dos agentes envolvidos e, em tempos de globalização, esse processo se amplia. Nesse período,

[...] o espaço geográfico ganha novos contornos, novas características, novas definições. E, também, uma nova importância, porque a eficácia das ações está estritamente relacionada com a sua localização. Os atores mais poderosos se reservam os melhores pedaços do território e deixam o resto para os outros. (Santos, 2000, p.79)

Para interpretar essa realidade é preciso atentar para um universo em constante transformação: as redes técnicas, que têm sido uma ideia empregada na ciência geográfica e que nesta obra terá papel de destaque para a compreensão das telecomunicações. Sendo assim, é importante frisar que: "A configuração territorial da ação das empresas de telecomunicação se dá através de suas redes. Não somente no seu aspecto material, mas também dos serviços e possibilidades que estas oferecem" (Toledo Junior, 2003, p.94).

Derivada do latim rēte, is ${ }^{6}$ a palavra rede já era empregada no século XII no sentido de expressar linhas e nós, bem como o entrelaçamento de fios. Além de servirem para organizarem tecidos animais, também eram utilizadas para se referir, em alguns casos, à totalidade do corpo biológico. René Descartes, por exemplo, consi-

6 Conforme o dicionário Houaiss. Disponível em <http://houaiss.uol.com.br/ busca? palavra=rede>. Acesso em: 21 set. 2015. 
derava que a rede era parte do cérebro e, portanto, tinha uma função central no corpo (Dias, 2005).

Claude-Henri de Rouvroy (Conde Saint-Simon), outro filósofo e economista preocupado com a temática, concebeu a ideia de organismo-rede para elaborar a proposição de uma ciência política, em um plano de desenvolvimento francês. Para ele, todo corpo humano se solidificaria quando a circulação era suspensa (Dias, 2005).

Saint-Simon teve ao longo de sua vida diversos discípulos que o auxiliaram a disseminar suas principais ideias no ambiente acadêmico e político da época, como Auguste Comte, Michel Chevalier, entre outros, que trabalharam com esse assunto e propunham, de diferentes maneiras, que as redes eram produtoras de relações sociais. "A rede não constitui o sujeito da ação, mas expressa e define a escala das ações sociais. As escalas não são dadas a priori, porque são construídas nos processos [...]" (Dias, 2005, p.23) por diversos agentes.

A rede, como um dado social, se mostra acrescida de valores da sociedade que a edificou em diferentes momentos, acompanhada por significados culturais, políticos que poderão desembocar em mensagens diversas entre pessoas. Em sua dimensão material, a rede se configura como infraestrutura capaz de transportar matéria, energia e informação, sendo também a representação de uma topologia constituída por pontos específicos de acesso ou mesmo terminais, com derivações particulares em nós, bifurcações, arcos de transmissão etc.

Outro uso da expressão das redes foi colocado em curso por meio de triangulações do espaço empreendidas, no século XVIII, para representarem a formação de redes geométricas. Eram elaboradas, sobretudo, por engenheiros cartógrafos e o território figurava como expressão de linhas imaginárias em rede. Daí em diante ganhou uma nova conotação que superava o corpo e tomava uma dimensão de técnica, verificada na telegrafia, infraestrutura, rodoviária e estradas de ferro, por exemplo.

Assim, lendo os trabalhos de Dias (2005) e Sposito (2008) pode-se destacar que na conformação das redes estão presentes a conexão, intermediação e a reciprocidade. Para compreender o signifi- 
cado das redes vários elementos são colocados como instrumentos analíticos para sua interpretação, a exemplo da sua referência estrutural: a investigação dos agentes que a produzem, dominam, transformam o território e suas diferentes expressões de fluxos. A partir disso, verifica-se a combinação de seus elementos de forma qualitativa na ligação e estruturação de distintos aspectos materiais da realidade, como os observados em partículas subatômicas, sistemas de galáxias, teias animais e em redes sociais de variada composição, como a dos imigrantes.

A utilização das redes está orientada para nomear tanto ações da vida comum como da ciência, o que dá a ela um sentido polissêmico com o significado diferenciado. Na Geografia, pode ser vista para o estudo linhas abstratas de cunho geocartográfico em meridianos e paralelos do globo, redes hidrográficas, redes territoriais, redes técnicas, redes de telecomunicações e, por conseguinte:

[...] Toda a história das redes técnicas é a história de inovações que, umas após as outras, surgiram em respostas a uma demanda social antes localizada do que uniformemente distribuída. Com a ferrovia, a rodovia, a telegrafia, a telefonia e finalmente a teleinformática, a redução do lapso de tempo permitiu instalar uma ponte entre lugares distantes: doravante eles serão virtualmente aproximados. (Dias, 2005, p.142)

A necessidade de comunicação do ser humano é a história da própria evolução da sociedade. Mesmo antes do desenvolvimento de uma linguagem articulada, essa necessidade já se fazia presente entre os hominídeos em sua estratégia de sobrevivência e reprodução. Assim, a comunicação ia se desenvolvendo, tornando-se mais complexa e abrangente, sendo um dado social e uma inovação que se renova a todo instante, por meio da criação de objetos técnicos que ampliam a capacidade de transmissão de mensagens e de levar a informação a distintos locais do mundo.

Relevante é destacar que as redes técnicas de transporte e comunicação modificaram a história da sociedade e a economia mundial, 
especialmente no século XX, no qual houve a maior difusão de tecnologias da informação, como ressaltado no tópico anterior por meio de diferentes inovações. Com isso, baseando-se em Sposito (2008) podem ser destacados três processos que fizeram parte do conjunto de mudanças estruturais no século XX, assentadas na revolução da informação, dos quais são sublinhadas: I) a demanda da economia flexível em tornar a produção da mais-valia mundializada e de possibilitar a gestão do capital integrada às principais capitais econômicas do globo; II) a liberdade individual dos membros da sociedade de se comunicarem cada vez mais com locais distantes de seu lugar de residência e trabalho; e, por último, III) os avanços da tecnologia da informação que se desdobraram no desenvolvimento de uma complexa arquitetura da internet.

Já Moreira (2007), acerca das mudanças processadas por meio da introdução das tecnologias da informação na sociedade, relatou que:

Com o desenvolvimento dos meios e transferência (transporte, comunicação e transmissão de energia), característica essencial da organização espacial da sociedade moderna - uma sociedade umbilicalmente ligada à aceleração das interligações e movimentações das pessoas, objetos e capitais sobre os territórios --, tem lugar a mudança, associada à rapidez do aumento da densidade e da escala de circulação. Esta é a origem da sociedade em rede [...]. (Moreira, 2007, p.57)

Sociedade em rede que se manifesta desigualmente pela incorporação da técnica de modo diferenciado no espaço e no tempo, onde o poder das corporações para a produção de novas tecnologias e inovações nas telecomunicações têm papel central na reprodução e ampliação do capital e desse ponto de vista concordar com Moreira (2007, p.62), uma vez que:

[...] a rede é o auge do caráter desigual-combinado do espaço. Estar em rede tornou-se para as grandes empresas o mesmo que dizer estar em lugar proeminente na trama da rede. Para ela não basta estar inserida. O mandamento é dominar o lugar, dominá-lo para 
dominar a rede. E vice-versa. Antes de mais, é preciso se estar inserido num lugar, para se estar inserido na geopolítica da rede. Uma vez localizado na rede, pode-se daí puxar a informação, disputar-se primazias e então jogar-se o jogo do poder. Entretanto, para que os interesses de hegemonia se concretizem, é preciso conjugar o segundo mandamento: é o controle da verticalidade que dá o controle da rede.

Ou seja, a rede representa no estado atual o domínio e controle do espaço acerca das condições de infraestrutura da técnica e da produção da informação e, consequentemente:

É conveniente, pois, decifrar as redes por meio de sua história e do território no qual estão instaladas, por meio dos modos de produção que permitiram a sua instalação e das técnicas que lhes deram forma [...]. (Raffestin, 1993, p.209)

Essas também podem ser apreendidas do ponto de vista conceitual e serem divididas, grosso modo, para o estudo da técnica em duas. Nesse sentido, Curien e Gensollen (1985, p.48) colaboraram para produzir um par geográfico pertinente para esse debate ao afirmar que as redes de infraestrutura podem ser consideradas como redes-suporte (réseaux-supports) e serviços-rede (services-réseaux), aquelas que têm articulação com o serviço prestado pelas redes-suporte. Em outras palavras, tal concepção auxilia no processo de interpretação da realidade material e didaticamente concebe uma trilha para explicar e ler o território a partir do estudo das redes.

Desse modo, como se verifica, a compreensão das redes técnicas perpassa por um estudo bastante aprofundado das inter-relações entre diversos objetos e ações. Nesse sentido, é preciso ter em vista o movimento contraditório da sociedade, em diferentes contextos, o que acaba por ter repercussão direta na forma como os agentes irão se apropriar de diferentes modos das invenções e reproduzir relações de poder diferenciadas. 
De acordo com Raffestin (1993, p.157): "Toda rede é uma imagem do poder ou, mais exatamente, do poder do ou dos atores dominantes [...]". Se as redes são manifestações do poder estabelecido, é necessário verificar em que medida estas foram engendradas, bem como interpretar as transformações subjacentes desse processo. As empresas, por seu turno, conformam redes em suas estratégias de uso corporativo do território, em distintas áreas de atuação no globo e produção normativa, mas são reguladas, sobretudo, pela ação dos diferentes Estados, além de apoiadas por instituições de crédito internacionais.

Ademais, é possível constatar que as transformações socioespaciais não podem ser traduzidas como expressão da neutralidade e inércia, mas pela sua dinamicidade, história e sua vinculação com normatizações territoriais e a técnica existente em cada período. Como afirmou Milton Santos (2005, p.146), é possível “[...] examinar as transformações do espaço geográfico - como o fenômeno de globalização que lhe constitui a causa". Nessa perspectiva, a difusão específica de um sistema técnico tende a unificar as ordens dos diversos lugares sendo, portanto, considerada como um suporte para a globalização.

A partir disso, verifica-se que essa unicidade é regida pela convergência do tempo instantâneo e simultâneo, organizada pelas tecnologias da informação e comunicação, em diferentes momentos. As grandes corporações que atuam nos serviços de telecomunicações são as responsáveis, portanto, por dar fundamentação a esse processo, buscando extrair constantemente mais-valia mundializada, em operações complexas que trazem como repercussão socioespacial o aprofundamento da divisão territorial do trabalho e regionalizações artificiais do ponto de vista de sua atuação.

Contudo, para decifrar a realidade material não é apenas preciso ter em mente a política das empresas, mas também do Estado, pois, "as técnicas apenas se realizam, tornando-se história, com a intermediação da política, isto é, da política das empresas e da política dos Estados, conjunta ou separadamente" (Santos, 2001, p.26). 
Finalmente, tendo em vista tais discussões, é tendo o Brasil como recorte espacial e a análise dos serviços de telecomunicações como recorte temático que serão apresentados no próximo item a discussão das telecomunicações no uso do território, por meio da sua evolução ao longo do tempo, no processo de integração territorial, bem como a privatização do setor contemporaneamente e a ação do Estado. 


\section{2 \\ As TELECOMUNICAÇÕES NO USO DO TERRITÓRIO}

\section{Evolução das infraestruturas de telecomunicação no processo de integração territorial do Brasil}

A formação socioespacial brasileira apresenta características de desenvolvimento desigual e combinado. A implantação de determinadas infraestruturas técnicas esteve historicamente relacionada aos locais em que há maior circulação de pessoas, bens e dinheiro, o que tem uma repercussão direta na forma como são produzidas e organizadas as telecomunicações no território. Do litoral ao interior as diferenças econômicas e materiais são visíveis, demonstrando a concentração e a dispersão, a pobreza e a riqueza, a monumentalidade e a fealdade, a comunicação e a ausência de sinal.

Tozi (2005), baseado em Castillo (2003), escreveu que há:

[...] três atos da integração do território brasileiro, a partir da difusão de objetos técnicos que se sucedem desde a segunda metade do século XX. A radiotelegrafia e a aviação seriam os vetores do primeiro ato da integração proposto, uma vez que são as formas mais rápidas e eficazes, nesse momento histórico, de se manter a inte- 
gridade e a integração do território brasileiro, exigindo, também, menos infra-estruturas. $\mathrm{O}$ rodoviarismo e a telefonia caracterizam o segundo ato da integração. As rodovias possibilitaram integrar as grandes regiões do Brasil aos centros de comando político e econômico do território, enquanto que a telefonia é nesse momento estatizada e centralizada, ou seja, a variedade de pequenas numerosas empresas até então existentes é transformada em patrimônio público e integrada aos projetos estatais. Já o terceiro ato ou atual paradigma da mobilidade geográfica (ibidem: 8) traz a incorporação das tecnologias da informação aos sistemas técnicos de fluxos materiais e imateriais. (Tozi, 2005, p.45 e 46, grifo do autor)

Tecnologias da informação que se vinculam aos ciclos de inovação da economia e que se relacionam presentemente à terceira revolução industrial, como compareceram, em diferentes momentos, nas reflexões de Mamigonian (1999) e Silveira (2003), interpretadas no capítulo que antecedeu essa argumentação.

Portanto, é nesse bojo que se insere a análise das telecomunicações, levando em conta a interpretação das disparidades, bem como os usos que são processados na dinâmica corporativa do território que é, ao mesmo tempo, amparada e regulada pelo Estado. Porém, antes de tudo, é preciso não perder de vista a história e os condicionantes que estiveram presentes em tal realidade.

No começo, o Brasil apresentava uma formação cuja configuração em termos econômicos de interação espacial assemelhava-se a ilhas e arquipélagos. Na realidade, havia pouca ligação entre as cidades e a ocupação era praticamente circunscrita às regiões litorâneas e faixas adjacentes, com reduzida abertura para o interior.

Mamigonian (2009, p.50-51), baseando-se em Rangel (1968), a esse respeito forneceu os elementos interpretativos para a análise do período, visto que:

O Brasil chegou até o século XX "sob forma de um imenso território muito desigualmente ocupado e apresentando quase que exclusivamente ao longo da costa formações econômicas regionais, 
geralmente estruturadas em torno de um porto-empório, orientadas mais para o comércio exterior do que para o comércio com outras regiões, tendo cada uma como espinha-dorsal um sistema regional de transportes, o qual servia de base a um esquema regional de divisão social do trabalho", conforme assinalou Ignácio Rangel. ${ }^{1}$

Antes, determinadas cidades tinham maior interação com o exterior do que com núcleos urbanos na dimensão nacional. Além disso, não havia transporte terrestre na forma de automóveis como conhecemos hoje, o que dificultava, por outro lado, os deslocamentos das pessoas e, consequentemente, a troca de bens, serviços e matérias-primas entre as unidades administrativas de cada região. Para Brandão (1996, p.39) tal cenário:

[...] apresentava enormes descontinuidades geográficas. Impermeáveis ao avanço do progresso material. Este arquipélago regional, verdadeiro mosaico de economias regionais fragmentadas, foi sendo cristalizado em processos de longa duração associados ao nascimento, auge e declínio dos diversos "ciclos" econômicos [...].

Porém, vale frisar que essa configuração paulatinamente foi sendo alterada com a introdução de diversas inovações técnicas. Por Jouffroy e Fitch, por exemplo, na década de 1790 foi colocada em curso a navegação a vapor no Brasil, sendo que esta só foi tornar-se mais regular no século XIX (Dias, 1995). Tal evento favoreceu a circulação do Pará ao Rio Grande do Sul, abrangendo rios como: São Francisco; Amazonas e seus afluentes Madeira, Tocantins e Negro; Rio da Prata; Paraguai e Paraná, além de outros importantes corpos hídricos do país (Dias, 1995).

As estradas de ferro também trouxeram mudanças significativas no final do século XIX. Tal evento favoreceu, sobretudo, o

1 Mamigonian (2009) citou a referência da seguinte maneira: Rangel, I. Características e perspectivas da integração das economias regionais. Revista do BNDE, 1968. 
escoamento de mercadorias e pessoas, além de propiciar a integração e dinamização do território. Possibilitou, consequentemente, o nascimento de diversas cidades, ocupação do interior (distante da capital paulista) e o escoamento da produção cafeeira até ao porto de Santos, rumo à exportação, o que fez abalar a hegemonia econômica carioca vigente.

O telégrafo foi outro evento e inovação da técnica importante para integração territorial, sendo que a primeira linha instalada oficialmente no país se constituiu na cidade do Rio de Janeiro por volta de 1852, no Palácio do Imperador Dom Pedro II, Paço de São Cristovão. Segundo Dias (1995, p.36): "En 1866, les lignes telégraphiques terrestres présent aient déja une étendue de dix mille kilomètres, reliant les principales villes des régions sudeste et sud du pays [...]". Deste marco em diante, outras linhas telegráficas foram implantadas, favorecendo a ampliação de fluxos informacionais, como ilustra o Quadro 4.

Quadro 4 - Expansão das linhas telegráficas entre 1857 e 1915.

\begin{tabular}{|c|c|c|c|}
\hline \multicolumn{4}{|c|}{ Expansão das linhas telegráficas entre 1857 e $1915^{*}$} \\
\hline Períodos & Terrestres & \multicolumn{2}{|c|}{ Por cabos submarinos } \\
\hline $1857-1866$ & $\begin{array}{c}\text { São Paulo, Paraná, Santa } \\
\text { Catarina, Rio Grande do Sul }\end{array}$ & Nacional & Internacional \\
\hline $1867-1876$ & $\begin{array}{c}\text { Espírito Santo, Bahia, Sergipe } \\
\text { Alagoas, Paraíba, Rio Grande } \\
\text { do Norte }\end{array}$ & $\begin{array}{c}\text { São Paulo, } \\
\text { Santa Catarina, } \\
\text { Rio Grande } \\
\text { do Sul, Bahia, } \\
\text { Pernambuco, } \\
\text { Pará }\end{array}$ & Portugal \\
\hline $1877-1889$ & $\begin{array}{c}\text { Ceará, Piauí, Maranhão e } \\
\text { Pará }\end{array}$ & & \\
\hline $1890-1915$ & $\begin{array}{c}\text { Goiás, Mato Grosso, } \\
\text { Amazonas }\end{array}$ & & $\begin{array}{l}\text { Paris (via } \\
\text { Dakar) }\end{array}$ \\
\hline
\end{tabular}

Fonte: Embratel (1984). Extraído de Dias (1995, p.37) e reformatado por Jurado da Silva (2011).

* A expansão das linhas telegráficas se deu a partir do Rio de Janeiro.

Marechal Cândido Rondon foi um dos grandes disseminadores dessa tecnologia da informação no território nacional que acompa- 
nhava, de certa maneira, o traçado de estradas. "Rondon participou da interiorização telegráfica durante três décadas, de 1890 a 1922, percorrendo 17.000 quilômetros [...].” (Brandão, 1996, p.53).

Já no que diz respeito ao telefone, pode-se afirmar que o seu estabelecimento inicial se deu no Rio de Janeiro. Iozzi (2006, p.19) considerou que:

[...] Em 15 de novembro de 1879 surgia no Brasil o primeiro telefone que foi instalado no palácio de verão do imperador, em Petrópolis, e fazia a ligação até o palácio do Rio de Janeiro. Em pouco tempo alguns comerciantes da cidade já utilizavam o serviço telefônico.

Depois desse período, sucessivas instalações telefônicas foram sendo efetuadas onde havia especialmente grande circulação de capital e pessoas, a exemplo dos centros nascentes emergentes polarizadores como São Paulo. "Já na década de 1920, o serviço telefônico abrangia pequenas parcelas das cidades do Rio de Janeiro, São Paulo e Porto Alegre, entretanto, só começa a ganhar força no país na metade do século XX” (Iozzi, 2006, p.19).

No começo do século XX, segundo Brandão (1996), empresas estrangeiras como a Siemens (1895), Ericson (1900), Sesa-ITT (1908) e Philips (1920) passam a operar no país com escritórios próprios. A Siemens criou até mesmo subsidiária com a finalidade de promover a importação de equipamentos, por volta de 1905. Contudo, só foi na década de 1920 que as demais concorrentes passaram a adotar tal estratégia.

Pouco a pouco as dificuldades de integração técnica do território foram sendo vencidas, com o avanço da urbanização e da industrialização, o que foi conferindo ao território novos usos e o integrando cada vez mais ao domínio do capital e a formação de um mercado.

A circulação por via rodoviária também favoreceu a expansão da técnica. O governo do Estado de São Paulo criou, em 1920, o primeiro plano rodoviário do país, conforme descreveu Dias (1995, p.50). Durante as guerras mundiais, as ferrovias passaram por um processo de decadência em razão de problemas com a importação 
de equipamentos e combustíveis, favorecendo a corrente que fundamentava seu discurso na expansão rodoviária, em Estados como Minas Gerais, São Paulo, Rio Grande do Sul, e o plano rodoviário foi instituído em 1944 (Dias, 1995, p.51).

Foi no governo de Getúlio Vargas, no entanto, que as transformações foram se processar de modo a integrar o território, visto que antes o país era constituído por ilhas econômicas e, dessa forma com:

[...] a extinção das barreiras à circulação de mercadorias entre os Estados da União marcou um avanço fundamental no processo de integração econômica do espaço nacional. Faltavam porém outras variáveis de sustentação, entre elas uma rede nacional de transportes. (Santos; Silveira, 2006, p.42)

No governo do presidente Getúlio Vargas² (1930-1945), o Brasil se integra no sentido da formação de um mercado consumidor nacional e, paulatinamente, são dadas as condições para que a indústria de base fosse criada e se dinamizasse, fomentando uma política industrial que atendesse aos interesses do chamado desenvolvimento nacional. Mamigonian (2009, p.51) relatou acerca do período que:

[...] foram as oligarquias agrárias baseadas no mercado interno que dirigiram o processo de industrialização do Brasil, podendo-se dizer que Getúlio Vargas desempenhou papel semelhante ao de Bismarck, ao substituir no poder os comerciantes export-import ligados à Inglaterra pelos industriais nacionais financiados pelo sis-

2 No período de 1930 a 1934 Getúlio Vargas governou o país como Chefe do Governo Provisório, que tinha colocado fim à República Velha (momento marcado pela alternância de poder político entre Minas Gerais e São Paulo), por meio da Revolução de 1930. De 1934-1937, Getúlio foi o Presidente da República eleito pela Assembleia Nacional Constituinte. Depois disso, aplicou um Golpe de Estado e fundou o Estado Novo no período de 1937-1945 e, mais tarde, foi eleito democraticamente, governando o país de 1951-1954. Interrompeu seu último mandato ao suicidar-se, no contexto das dificuldades e pressões políticas em termos de sustentação governamental. 
tema bancário norte-americano, acelerando o crescimento econômico e provocando um enorme rearranjo na organização territorial do país: o "arquipélago" brasileiro, constituído pelas "ilhas" voltadas para o exterior e vigente até 1930, foi rapidamente costurado em um único espaço nacional cujas fronteiras com o exterior foram reforçadas, além de dissolvidas as "fronteiras" interestaduais, com a supressão dos impostos entre os estados da federação e a crescente rodoviarização [...].

Nesse sentido, a rodovia Rio-Bahia, por exemplo, da década de 1940 foi a materialização da primeira conexão entre o Sudeste e Nordeste do país (Dias, 1995, p.51). Ademais, a participação do capital estrangeiro foi relevante, visto que: "Dans une association étroite avec le capital étranger, l'Etat prend en charge l'infracstruture routière et desire une nouvelle géographie de la circulation dans l'espace brésilien" (Dias, 1995, p.52). Com isso, as redes rodoviárias asfaltadas possibilitaram o fortalecimento de novas redes urbanas regionais. A integração econômica e física do território fortaleceu, por outro lado, a intensificação dos fluxos migratórios oriundos, sobretudo, da região Nordeste em direção a São Paulo.

Paulatinamente, diversas transformações socioespaciais foram sendo processadas no território nacional, como a construção de Brasília, instalação da indústria automobilística, criação e implantação de usinas hidrelétricas, construção de rodovias, ampliação da urbanização, da industrialização e investimentos em telecomunicações.

Nesse contexto, a exploração da telefonia fixa era prestada, em geral, por empresas privadas no plano do município e quando se tratava da escala intermunicipal, geridas pelo Estado. Brandão (1996, p.70 e 71) auxiliou a elucidar teoricamente esse período ao descrever que:

[... A A mutação tecnológica empreendida e a magnitude da capacidade instalada (abruptamente) geram um abalo violento - graças à materialização simultânea de vários projetos de grande porte principalmente nas indústrias de material de transporte, material 
elétrico e metal-mecânica que possibilita ondas inovativas primárias ("schumpeterianas") que se disseminam pelos elos mais dinâmicos da malha industrial.

Inovações essas que foram aceleradas no governo do presidente Juscelino Kubitschek ${ }^{3}$ (1956-1961) com a implantação do programa Plano de Metas. Este, por sua vez, tinha como objetivo ampliar e fortalecer o crescimento econômico do país, especialmente nos setores de energia, transporte, educação, alimentação e indústria de base, com a construção de grandes projetos nacionais, como a criação da capital político-administrativa federal, no Planalto Central: Brasília (Distrito Federal-DF).

Tal plano, apesar de ter trazido grandes benefícios em termos de infraestrutura técnica ao país, aumentou, por outro lado, a dívida externa. Foi a partir da liberalização econômica, no entanto, que o parque industrial nacional se diversificou e São Paulo mais uma vez foi beneficiada com a construção de indústrias de bens duráveis.

$\mathrm{Na}$ década de 1950, importantes estabelecimentos industriais do ramo petroquímico, como a Companhia Siderúrgica Paulista (Cosipa), se instalaram no litoral paulista e Cubatão (município localizado na chamada Baixada Santista Paulista e em proximidade a capital São Paulo) e passaram a concentrar expressivo aporte de investimentos. Se no primeiro recenseamento brasileiro, datado por volta de 1870, São Paulo contava com pouco mais de 31 mil habitantes, a partir de 1960 atinge aproximadamente 3,3 milhões de habitantes (Jurado da Silva, 2011, p.147). Os resultados desses múltiplos processos foram a concentração industrial, econômica e populacional na capital paulista, bem como a migração do campo para a cidade com o fortalecimento da urbanização.

Há uma diversificação da produção industrial brasileira, na qual o governo federal cria a Petrobras, além do BNDE (Banco Nacional

3 O grande slogan do Plano de Metas de Juscelino ficou conhecido como "Cinquenta anos em Cinco", ou seja, demarcando a estratégia presidencial de aumentar o ritmo de crescimento do país em curto espaço de tempo. 
de Desenvolvimento Econômico), e passa a investir pesadamente em infraestrutura com a participação maciça do capital externo, em busca da consolidação do setor de bens duráveis. Como considerou Negri (1996, p.101), no período há uma nítida concentração industrial em São Paulo, visto que:

A primeira fase da industrialização pesada (1955/1967) consolidou a expansão industrial brasileira e sua concentração em São Paulo, aí instalando grande parte da nova capacidade produtiva metal-mecânica. É em São Paulo, também, em função da maior diversificação de sua estrutura industrial, que se veem, com maior clareza, os efeitos de encadeamento dos investimentos do Plano de Metas, a exemplo da montagem do setor de autopeças em relação à automobilística [...].

Face a esse quadro, São Paulo firmou-se na gestão econômica do país, fazendo com que o poderio econômico e político do Rio de Janeiro (antiga capital do Brasil) fossem colocados em segundo plano. Tanto São Paulo quanto Brasília acabaram por se configurar como os novos centros de gestão econômica e política do território nacional.

O Brasil passa a se inserir no mundo capitalista como um país industrial e urbano, diferentemente da conotação que o país assumia no passado, quando a sua vinculação era agrária e exportadora - embora haja permanências, complementaridades e contradições nesse processo de desenvolvimento desigual e combinado. Como pontos estratégicos de incorporação capitalista do território nacional, com a construção de Brasília, foram implantadas diversas rodovias no país.

O processo de ocupação e expansão demográfica é acentuado, face especialmente ao avanço da urbanização no centro-oeste e norte brasileiro, consolidando-se os marcos para o estabelecimento de novas fronteiras agrícolas no país. Aos poucos o território é dinamizado e assegura-se a estratégia geopolítica de defesa das áreas de fronteira, centrada na política de ocupação e dotação de infraestrutura no território. 
Além disso, foi na gestão de Juscelino Kubitscheck que a questão das telecomunicações foi tomada como pauta da agenda governamental. Comissões conjuntas de estudos e ações com os norte-americanos foram criadas, bem como medidas tomadas no sentido de atrair investidores estrangeiros privados. Consequentemente, a Comissão Nacional de Comunicações foi instalada, tornando-se diretamente subordinada à presidência da república.

Ainda no começo da década de 1960, o campo da telefonia tinha como principais prestadoras de serviços empresas que nutriam vínculo com o capital internacional, como é o caso da Companhia Telefônica Nacional, subsidiária da International Telephone Telegraph, de origem estadunidense com atuação no Paraná e Rio Grande do Sul, bem como a Companhia Telefônica Brasileira que era subsidiária da Canadian Tractions Light and Power Company, com operações em São Paulo, Rio de Janeiro e Minas Gerais (Iozzi, 2005, p.21). Ademais, havia uma gama muito ampla de pequenas empresas com atuação em território nacional e com menor influência espacial e econômica, se comparada às maiores citadas.

Sobre esse cenário, Novaes (2000, p.48) sintetizou a atuação de companhias internacionais no território brasileiro quando afirmou que:

[...] a empresa telefônica predominante no Brasil era uma subsidiária da Canadian Traction Light and Power Company, que operava $62 \%$ das linhas telefônicas fixas instaladas no país, principalmente concentradas nos Estados do Rio de Janeiro e de São Paulo, tendo sido nacionalizada no final dos anos 60 . Os restantes $38 \%$ do mercado estavam divididos por mais de 800 entidades, entre prefeituras, empresas privadas e cooperativas espalhadas pelo resto do país. Com 1,3 milhão de telefones para uma população de 74 milhões de habitantes, o Brasil tinha em 1962 uma densidade de 1,7 telefone por 100 habitantes, em comparação com 14,8 linhas instaladas por 100 habitantes, na época da privatização da Telebrás. 
Consequentemente, no governo de João Goulart, foi criado o Código Brasileiro de Telecomunicações, na forma da Lei n. 4.117, em agosto de $1962^{4}$. A aprovação desse código possibilitou o disciplinamento da prestação de serviços, bem como colocou o segmento sob o controle federal, organizando um sistema de tarifação próprio e o planejamento naquilo que se poderia considerar como Sistema Nacional de Telecomunicações. Além disso, tais mudanças foram acompanhadas pela criação do Conselho Nacional de Telecomunicações (Contel), vinculado diretamente à presidência da república e do Fundo Nacional de Telecomunicações (FNT) e, por conseguinte:

L'intervention commence en 1962 quand le congress national vote le Code des Télécommunications. Les principals resolutions du code prévoyaient: a) la mise en place d'un Système National de Télécommunication; b) la creation du Conseil National de Telecommunications (CONTEL), directement relié au Présidente de la Rép1ublique, afin d'appliquer la politique génerale; c) l'institution des Fonds National des Télecommunications (FNT), don't les resseurces proviennent d'une surtaxation de $30 \%$ perçu sur les services de telecommunications; d) la formation d'une entité autonome ayant statu d'entreprise publique, pour installer et entretenir les services inter-urbains et internationaux. (Dias, 1995, p.77)

Já na ditadura militar, foi feita uma aliança entre militares e a ciência técnica. Foi estruturada a política nacional de telecomunicações e depois desencadeada a nacionalização da Companhia Telefônica Brasileira. Nesse quadro, foi criada a Embratel (Empresa Brasileira de Telecomunicações), com o claro objetivo de modernizar o segmento das telecomunicações. Isso porque havia alguns grupos pertencentes ao governo que eram favoráveis à aliança com concessionárias estrangeiras e outro bloco formado por militares e pelo Contel,

4 Referenciado em: <http://www.planalto.gov.br/ccivil_03/leis/14117.htm>. Acesso em: 18 ago. 2013. 
que apoiavam a criação de uma empresa pública. Tal entendimento desse contexto histórico faz-se importante porque justifica que:

A remodelação do território brasileiro, em razão da implantação das telecomunicações e dos sistemas de informática e informação, deve necessariamente recobrar o processo histórico dos anos 60, quando o empreendimento coube a direção do Estado, e nos anos 90, quando o grande negócio da privatização veio estabelecer o novo marco das expectativas. (Gomes, 2006, p.345)

Além disso, é válido ressaltar que a estatização das empresas privadas no processo de reestruturação das telecomunicações passa a ser um imperativo, na formação de um sistema nacional de telecomunicações, sendo levadas a cabo essas ações às últimas consequências nos governos militares. Este regime, por seu turno, passou a criar instrumentos legais e mecanismos para dinamizar tal processo e definitivamente patrocinar o desenvolvimento, aprimoramento e modernização do segmento. Um dos grandes passos tomados nessa direção foi a reforma ministerial de 1967, que possibilitou a criação do Ministério das Comunicações, pelo Decreto-Lei n. 200, bem como a absorção do Contel por este Ministério e, por fim, a Telebrás (Telecomunicações Brasileiras) em 1972, e essa tinha a função de:

[...] incorporação (estatização) das operadoras locais e desta ação resultou o Sistema Telebrás (STB), constituído por: uma empresa holding (a Telebrás); a Embratel (que explorava os serviços de longa distância de âmbito nacional e internacional, comunicações de dados e de telex); 27 subsidiárias (empresas pólo presentes em todos os estados brasileiros) e 4 empresas independentes (porém integradas tecnicamente ao sistema). Dessas quatro empresas de serviços telefônicos não pertencentes ao Sistema Telebrás, três eram estatais: a Companhia Riograndense de Telecomunicações (CRT, controlada pelo governo do estado do Rio Grande do Sul); a Serviços de Comunicações de Londrina (Sercomtel, controlada pela prefeitura de Londrina-PR) e a Centrais Telefônicas de Ribeirão 
Preto (CETERP, operadora da prefeitura de Ribeirão Preto-SP) e uma operadora era privada - a Companhia de Telecomunicações do Brasil Central (CTBC), cuja atuação abrangia o Triângulo Mineiro e alguns municípios dos estados de São Paulo, Goiás e Mato Grosso do Sul (Anatel, s.d.). (Iozzi, 2006, p.24)

À União competia explorar os serviços de telecomunicações, mas também autorizar a sua concessão e efetiva autorização. Em 1968 é inaugurada a Rede Nacional de Microondas, o Sistema de Transmissão de Satélites e pouco a pouco foram sendo dados os passos para a comunicação no plano internacional por satélites e a configuração do sistema de DDD - Discagem Direta à Distância (Iozzi, 2006, p.23).

Em 1975, deu-se início ao plano da política industrial das telecomunicações e empresas de capital externo passaram a produzir no Brasil no segmento da informática como Ericsson, entre outras. Investimento nacional ${ }^{5}$ foi feito na área, mas coube ao Estado a criação do Grupo Executivo da Indústria de Componentes para Comunicação (Geicom) em 1975 e, no ano seguinte, a criação do CPqD (Centro de Pesquisa e Desenvolvimento da Telebrás), em Campinas (interior de São Paulo), possibilitando a elaboração de projetos em conjunto com universidades e empresas, no segmento de alta tecnologia, como os programas de comunicação por satélite e outros sistemas ópticos.

Com o surgimento da Telebrás, o Sistema Brasileiro de Telecomunicações passou a:

[...] ter a seguinte organização: em nível superior, o Ministério das Comunicações (MINICOM), que tinha como função estabelecer as diretrizes gerais do desenvolvimento do setor, além de sua regulação; em um nível intermediário, a Telebrás, que coordenava o sistema, adquiria os equipamentos necessários, aplicava os recursos e promovia o desenvolvimento tecnológico por via do CPqD; na base do

5 Referenciado em Brandão (1996, p.104). 
sistema estavam as 27 empresas subsidiárias, que operavam em cada estado da federação as redes urbanas e intraestaduais, e a Embratel, que operava os serviços de longa distância (nacional e internacional) e também oferecia serviços de comunicação de dados, telex e telégrafo (Almeida e Crossetti, 1997:21). (Iozzi, 2006, p.25)

Nesse sentido, o CPqD realizou a coordenação de diversos programas de intercâmbio, parceria e cooperação com empresas, estabelecimentos industriais e universidades. Essa iniciativa trouxe a redução da dependência tecnológica, viabilizando a expansão dos serviços prestados pelas empresas de telecomunicações, principalmente com investimento na área de fibra óptica, comutação temporal, tecnologia por satélite e serviços de transmissão de informação por rádio.

Nesse momento, os sistemas de comunicação eletrônica e digital passaram a ser incorporados no território nacional, e: "[...] A regulação pelo poder público foi o motor desses processos, com a criação da Empresa Brasileira de Telecomunicações S.A. (Embratel), em 1965, e das Telecomunicações Brasileira S.A. (Telebrás), em 1972 [...].” (Santos; Silveira, 2006, p.81).

Dessa forma, a indústria bélica, aeronáutica e das telecomunicações adquiriram um papel de grande destaque na ditadura militar, alimentando a ideologia geopolítica de autonomia e desenvolvimento nacional. Foi nesse quadro que o governo federal atuou no território nacional, visando incentivar a instalação de indústrias em outras localidades da federação, fundamentando-se, para tanto, na teoria dos Polos de Desenvolvimento, baseada nas ideias de François Perroux.

A partir da década de 1970, é criada a Zona Franca de Manaus (polo comercial localizado na região Norte do país, que se destaca especialmente no segmento de produção de eletrônicos), assim como são implantados a Rodovia Transamazônica e o Polo Petroquímico de Camaçari, na Bahia.

Tal processo de reestruturação das telecomunicações possibilitou a organização do sistema nacional e a modernização técnica do segmento. Além disso, ofereceu as condições necessárias para a alteração de paradigma que vigia no mercado, baseado somente 
na ação isolada e pulverizada das empresas privadas no território. Com isso, no período:

Entre 1974 e 1975 ocorreram eventos importantes, como a regulamentação que estabelecia as regiões prioritárias para a implantação da telefonia móvel terrestre entre São Paulo, Rio de Janeiro e Distrito Federal. Foram instaladas antenas em Manaus e Cuiabá para atender aos serviços domésticos via satélite e a nova Rede Nacional de Estações Costeiras. Em 16 de setembro de 1975, inaugurou-se a Estação de Tanguá II. Três anos mais tarde, surgem três novas Estações Terrenas de Comunicações Domésticas via satélite: Porto Velho (RO), Rio Branco (AC) e Macapá (AP), e em 1979, é inaugurada a Estação Tanguá III (RJ). (Tatsch, 2003, p.49)

De certa maneira, tais avanços trouxeram como principais benefícios o investimento em inovação, a instalação de um sistema telefônico integrado nacionalmente e, posteriormente, a concessão de operação de mais canais de TV.

Já em 1980, entrava em operação, de acordo com Tatsch (2003, p.50), o cabo submarino Brus, que conectou os Estados Unidos ao Brasil, facilitando o fluxo de informações entre tais países. Além disso,

A rede Nacional de Televisão por Satélite (TV SAT) e o sistema de cabos submarinos Atlantis foram inaugurados em outubro de 1982. No ano seguinte, os computadores da Bolsa de Valores do Rio de Janeiro e da Rede Nacional de Telex passam a operar interligados, e é inaugurado o Serviço Internacional de Acesso a Informações Financeiras (Findata). (Tatsch, 2003, p.50)

Com isso, em 1985, o Brasil lançou seu primeiro satélite geoestacionário, ${ }^{6}$ o Brasilsat AI, e, em 1986, o Brasilsat AII. Na-

6 Informação referenciada na Agência Espacial Brasileira. Disponível em: < www.aeb.gov.br/2011/09/satelites-de-comunicacoes-serao-parte-do-programa-espacial-brasileiro-2/>. Acesso em: 21 set. 2015. 
quele momento, era um privilégio para poucas emissoras gozar de cobertura nacional como a Globo e a Bandeirantes. "[...] Foi nesses anos que se constituiu o Sistema Brasileiro de Televisão (SBT), graças a utilização de um transponder do Brasilsat 2 [...]" (Santos; Silveira, 2006, p.75) e logo: "[...] O caminho para diversificação das redes nacionais de emissoras de televisão no país estava aberto" (Santos; Silveira, 2006, p.75).

Contudo, esse padrão de transformações no segmento revelou-se esgotado, especialmente nas décadas de 1980 e 1990, quando se tornou alvo do ideário privatista. Mesmo assim, em 1994 foi lançado o satélite geoestacionário Brasilsat B1, em 1995 o Brasilsat B2 e em 1998 o Brasilsat B3, conforme a Agência Espacial Brasileira. ${ }^{7}$

Nesse período, a indústria de equipamentos de telecomunicação se comportou ociosamente e os investimentos do Estado passaram por uma redução considerável, se comparados ao período da ditadura militar. Ademais, ainda na década de 1980 o país é sacudido pela crise da dívida externa e o processo de redemocratização colocado em curso.

Depois desse momento, a liberalização da economia passa a ser dominante, sobretudo nos governos Fernando Collor de Mello (1990-1992), Itamar Franco (1992-1994), Fernando Henrique Cardoso (1995-2002), no qual parte das empresas estatais é leiloada ao capital internacional e nacional privado, favorecendo os grupos de interesse ligados à sustentação de políticas neoliberais e um plano de enxugamento da máquina pública, o que se traduziu, por outro lado, na desestatização e na redução das políticas públicas voltadas ao crescimento econômico. Nas palavras de Brandão:

A real história da desorganização fiscal-financeira do setor público brasileiro é a de um Estado bancador em última instância do padrão de desenvolvimento capitalista no País, que levou às derradeiras consequências, na crise que se prolonga desde o final dos anos 70, seu histórico papel de mobilizador de recursos, trans-

7 Disponível em: < www.aeb.gov.br/2011/09/satelites-de-comunicacoesserao-parte-do-programa-espacial-brasileiro-2/>. Acesso em: 21 set. 2015. 
feridor de fundos e, acima de tudo, socializador de perdas; além de agente da regulação macroeconômica e investidor direto, terminou por se tornar o mutuário final que arcou com todo o ônus e os riscos do ajustamento do setor privado na "década perdida". Colapsa totalmente sua capacidade de gasto e iniciativa, se tornando refém do setor privado líquido e imobilizado em sua ação reguladora e estruturante. (Brandão, 1996, p.115 e 116)

Isso teve como repercussão direta o agravamento do cenário de desemprego, colocando em dificuldades os grupos nacionais, que agora tinham que concorrer mais abertamente com os oligopólios e o capital internacional depois de efetuada a abertura econômica. Isso foi sentido especialmente nos estabelecimentos de setores mais tradicionais da indústria como as confecções, têxteis e calçadistas.

Nesse sentido, a década de 1990 foi marcada fortemente pela abertura ao capital estrangeiro e ao ideário das privatizações. A inflação foi controlada e as políticas de controle fiscal colocadas em curso. Onda essa que golpeou diversos países da América Latina e que colocou em cena a competição no uso corporativo do território por uma parcela de oligopólios internacionais em consórcio, muitas vezes com o capital nacional.

As telecomunicações, nesse quadro, foram desestatizadas e grupos internacionais passaram a atuar no mercado com estratégias de grande amplitude e atreladas a movimentos em escala global de investimento. Houve, com isso, a venda do Sistema Telebrás ao capital privado no modelo de concessão, baseada na rentabilidade que os serviços poderiam oferecer às companhias operadoras.

\section{A privatização das telecomunicações no Brasil}

O tema da privatização das telecomunicações (especialmente telefonia celular e fixa) começa a ganhar eco durante o debate da Constituinte. $\mathrm{O}$ debate ocorria entre aqueles que defendiam o 
modelo de liberalização do setor e a venda ao capital privado do Sistema Telebrás e os que advogavam a necessidade do Estado em manter tais serviços sob sua tutela, em razão da segurança nacional e de ser um setor estratégico da economia, investindo na sua universalização.

Assim, Dalmazo (2002) foi um dos autores que se preocupou em refletir sobre a privatização dos serviços de telecomunicação no país, explicando com detalhes tal contexto ao elucidar que:

A política de abertura ganhou, de fato, contornos radicais no período 1990-93. A coleção de derrotas dos privatistas até então não atenuou o ímpeto das suas reinvindicações, que tinham por bandeira palavras de ordem: entre 1990 e 1993, a bandeira foi a liberalização para a entrada da iniciativa privada; entre 1994 e julho de 1995, foi a flexibilização do modelo tradicional; e a privatização a partir de meados de 1995 [...]. (Dalmazo, 2002, p.95, grifo do autor)

Com isso, o discurso privatista foi o vencedor político desse debate. Em 15 março de 1990 foi aprovada a Medida Provisória 155, que iria ser elemento importante no Programa Nacional de Desestatização do Brasil e depois convertida na Lei n. 8.031. Como a Constituição de 1988 excluía área de serviços públicos, como as telecomunicações da desestatização, foi encaminhada emenda constitucional para romper com o monopólio estatal, vigente no governo de Fernando Collor de Mello.

A Lei n. 8.0319 , de 12 de abril de 1990, em seu artigo 13, item IV, tratou de regulamentar a desestatização de empresas públicas, possibilitando que $40 \%$ do capital votante pudessem pertencer a pessoas jurídicas ou físicas. Entretanto, o que totalmente abriu

8 Disponível em: < www.planalto.gov.br/ccivil_03/leis/L8031.htm>. Acesso em: 21 set. 2015.

9 Disponível em: <www.planalto.gov.br/ccivil_03/leis/L8031.htm>. Acesso em: 21 set. 2015. 
caminho para o processo de desestatização foi o Decreto n. 1.204 de 29 de julho de $1994,{ }^{10}$ que consolida a lei anterior e a altera.

Em 1995, foi aprovada a retirada do monopólio da Telebrás. Essa operação seria acompanhada pela tarefa de reduzir as distorções dos planos de tarifas internacionais e nacionalmente, além de extinguir subsídios envolvidos entre tarifas locais e de longa distância, que envolvia a Embratel. Isso levou consequentemente a um aumento tarifário muito grande no mercado, trazendo prejuízos especialmente aos consumidores. Segundo Novaes (2000, p.152), em 1995, a Telebrás mantinha:

[... 13 milhões de linhas instaladas, controlava o maior sistema telefônico da América Latina, sendo a $11^{a}$ do mundo. O faturamento líquido anual da Telebrás era da ordem de US\$ 7,5 bilhões, e a empresa controlava 95\% das linhas telefônicas brasileiras [...].

Já outra medida alinhada ao ideal liberalizante da época foi a criação do PASTE (Programa de Recuperação e Ampliação do Sistema de Telecomunicações e do Sistema Postal) com o claro objetivo de melhorar as infraestruturas de telecomunicação no país e valorizar as respectivas empresas para a privatização do setor, no âmbito de inserção da população na chamada "sociedade da informação", visto que:

[...] o PASTE dá destaque para três proposições fundamentais. Primeiro, a disponibilidade de adequada infra-estrutura de telecomunicações é fator determinante para a inserção de um país no contexto econômico internacional. Segundo, os países mais desenvolvidos estão incrementando velozmente seus investimentos na infra-estrutura de telecomunicações, visando promover o desenvolvimento da Sociedade da Informação. Terceiro, os países em desenvolvimento, como o Brasil, devem integrar-se urgentemente

10 Disponível em: <www.planalto.gov.br/ccivil_03/decreto/D1204.htm>. Acesso em: 21 set. 2015. 
a essa revolução, com o fim de potencializar as oportunidades oferecidas por essas novas tecnologias e, assim, estimular o seu desenvolvimento social, político e econômico (Paste, 1995). ${ }^{11}$

No cenário da privatização, Pochmann e Porto (2000) consideraram que houve um falso argumento de que o Sistema Nacional de Telecomunicações não tinha mais capacidade para investimento no segmento quando na realidade possuía e, desse modo, os:

[...] investimentos realizados por empresas estatais entravam como se fossem despesas, para efeito de cálculo do déficit público, o que dificultava o cumprimento de metas estabelecidas com o FMI. Portanto, critérios curiosos de cálculo de déficit público, mas, principalmente uma postura ideológica no sentido de privatizar empresas estatais e necessidade de fazer caixa para pagamento de dívida externa parecem ter sido as principais razões para privatização do SNT, ao contrário de incapacidade de investimento ou até mesmo ineficiência operacional, como muitas vezes é afirmado. (Pochmann; Porto, 2000, p.34)

Nesse contexto, três leis aprovadas no congresso tiveram papel decisivo para a abertura do mercado e para aceleração do processo de privatização, a saber: I) Lei Específica, ou seja, a Lei n. 9.295 (Lei Mínima) de 19 de julho de 1996, que autorizava a prestação de serviços via satélite, redes corporativas, trunking and paging, telefonia móvel celular (inserida na banda larga B) para exploração pela iniciativa privada; II) Lei de concessões de serviços públicos por meio da aprovação da Lei n. 8.987 de 13 de fevereiro 1995, aplicada aos serviços de telefonia móvel celular; e, por fim, III) Lei n. 8.977 de 6 de janeiro de 1995, também conhecida como Lei da TV a Cabo, que definia a regulação do segmento e impunha diretrizes para concessão desse tipo de serviço no mercado nacional.

11 (Teleco. Disponível em: <www.teleco.com.br/tutoriais/tutorialmbassin/ pagina_3.asp>.Acesso em: 21 set. 2015) 
Contudo, a lei ${ }^{12}$ que definitivamente providenciou a desestatização do sistema de telecomunicações brasileiro foi assinada em 16 de julho de 1997: a Lei n. 9.472 que ficou conhecida como Lei Geral das Telecomunicações, amparada pelo Plano Geral de Outorgas, sob o Decreto n. 2.534 de 2 abril de 1998 e pelo Plano Geral de Metas para a Universalização do Serviço Telefônico Fixo Comutado em caráter público, por meio do Decreto n. 2.592 de 15 de maio de 1998.

Lima (1998), a respeito da Lei Geral das Telecomunicações e suas implicações no domínio da política e da economia, ressaltou que:

Essa nova política favorece a concentração da propriedade porque não impede a propriedade cruzada dos grupos empresariais de telecomunicações, comunicação de massa e informática; e estimula a participação crescente dos global players, diretamente ou associados aos grandes grupos nacionais, na medida em que elimina todas as barreiras para a entrada do capital estrangeiro (Lima, 1998b). (Lima, p.122, grifo do autor)

Além disso, o governo brasileiro celebrou, nesse momento, acordo de cooperação direta com a União Internacional de Telecomunicações (UIT), objetivando apoio técnico com vistas à modernização do setor no Brasil, com um orçamento milionário para isso. Tal empreitada, por outro lado, foi a responsável pela contratação de consultorias internacionais para o estudo do setor, entre elas a McKinsey \& Company, Inc. ${ }^{13}$ que foi a principal nesse quesito (Lima, 1998, p.124).

12 Baseado na pesquisa e consulta da legislação sobre o tema disponível a partir do sítio do Planalto em: <http://www.planalto.gov.br/ccivil_03/>. Acesso em: 18 ago. 2013.

13 Lima (1998, p.125, grifo do autor) escreveu que: “[...] a McKinsey é uma das maiores empresas de consultoria do mundo, com 75 escritórios em 38 países, inclusive no Brasil, e assessora governos e empresas 'tais como aquelas na lista das 500 maiores dos EUA da revista Fortune e suas equivalentes nos respectivos países'. Kenichi Ohmae, sócio-senior por mais de 20 anos da McKinsey no Japão, ficou mundialmente famoso ao publicar o livro O Fim do Estado Nação, 
Nesse contexto, para gerir esse novo regime de exploração dos serviços de telecomunicações, foi criada a Anatel (Agência Nacional de Telecomunicações), por meio do artigo 8 da Lei Geral de Telecomunicações. Já a regulamentação da Agência se deu pelo Decreto n. 2.338 de 7 de outubro de 1997, com sede no Distrito Federal e vinculando-se ao Ministério das Comunicações. Além disso, entre as suas atribuições poderiam ser citados os seguintes aspectos:

- implementar, em sua esfera de atribuições, a política nacional de telecomunicações;

- expedir normas quanto à outorga, à prestação e à fruição dos serviços de telecomunicações no regime público;

- administrar o espectro de radiofrequências e o uso de órbitas, expedindo as respectivas normas;

- expedir normas sobre prestação de serviços de telecomunicações no regime privado;

- expedir normas e padrões a serem cumpridos pelas prestadoras de serviços de telecomunicações quanto aos equipamentos que utilizarem;

- expedir ou reconhecer a certificação de produtos, observados os padrões e normas por ela estabelecidos;

- reprimir infrações dos direitos dos usuários; e

- exercer, relativamente às telecomunicações, as competências legais em matéria de controle, prevenção e repressão das infrações da ordem econômica, ressalvadas as pertencentes ao Conselho Administrativo de Defesa Econômica (Cade). ${ }^{14}$

em 1995 - dedicado, aliás, aos seus ex-colegas da McKinsey - no qual argumenta que, além de ineficientes, os Estados nacionais são apenas 'dinossauros esperando a morte"”.

14 Anatel. Extraído de: < www.anatel.gov.br/Portal/exibirPortalInternet.do>. Acesso em: 21 set. 2015. 
Funcionando como autarquia especial, a agência é financeiramente autônoma e possui caráter administrativo independente. Suas decisões só podem ser contestadas por via judicial e os responsáveis pela sua direção possuem mandatos fixos. Além disso, a partir da criação dessa agência, o Ministério das Comunicações passou a ter seu papel reduzido no cenário das telecomunicações, no sentido de ser um ente regulador do setor.

A sede da Anatel fica em Brasília, mas a Agência mantém nos estados unidades representativas. ${ }^{15}$ Há escritórios regionais em São Paulo, Rio de Janeiro, Belo Horizonte, Porto Alegre, Curitiba, Goiânia, Salvador, Recife, Fortaleza, Belém, Manaus; e unidades operacionais em Florianópolis, Vitória, Distrito Federal, Aracaju, Maceió, João Pessoa, Natal, Teresina, São Luís, Palmas, Cuiabá, Campo Grande, Rio Branco, Porto Velho, Boa Vista e Macapá.

Com a ação da Anatel e a privatização do setor, o território foi preparado no campo normativo e técnico para o uso corporativo na instância privada, associando a ideia de que essa mudança seria boa para as pessoas, na tentativa de promover o convencimento popular e, portanto,

O discurso criado para sustentar a privatização parte da ideia de que os serviços públicos cuidados pelo Estado são ineficientes e de que as empresas privadas podem realizá-los com maior eficiência, ou seja, adotam o pressuposto de que o mercado é um ente perfeito, e que a alocação dos fatores pelo mercado é ótima e eficiente. São ações fundadas numa teoria estática, baseada na concorrência perfeita e em pretensas leis universais que ignoram as situações reais das formações sócio-espaciais. Outro ponto a ser destacado é que o Estado, nesse discurso construído, deve agir unicamente corrigindo as falhas no equilíbrio do mercado. A economia neoclássica, portanto, parte da idéia de que há dois agentes principais: os produtores, que objetivam maximizar a renda e o lucro e os consumi-

15 Dados da Anatel. Disponível em: <http://www.anatel.gov.br/hotsites/Anatel_nos_Estados/endereços_da_anatel_inter.htm>. Acesso em: 29 jul. 2013. 
dores, que satisfazem suas necessidades e aos quais cabe o prazer do consumo (com base em Cano, 2002). (Tozi, 2005, p.115)

Aos consumidores foi colocada a afirmação de que os serviços seriam barateados, os custos para instalação cairiam e que esse processo levaria futuramente a uma universalização das telecomunicações no Brasil. Com isso, é preciso ter em vista que:

A privatização do sistema de telecomunicações acontece a partir da cessão onerosa às empresas do direito de exploração de toda uma infra-estrutura construída pelo poder público. Essa transferência de poder é parcialmente acompanhada de uma transferência de responsabilidades, uma vez que a empresa não tem (e não deve ter se quiser manter os níveis de competitividade exigidos no período atual) compromisso com os lugares, as regiões ou mesmo os territórios nacionais e tampouco com as sociedades que esses compartimentos geográficos abrigam. A lógica que rege a atuação de um agente do mercado é particularista e tende a transformar direitos em mercadorias, isto é, cidadãos em usuários ou consumidores (Santos, 2002). (Iozzi, 2006, p.1)

O território, nessa concepção, se torna um recurso e pode ser vendido às grandes corporações para legitimar as normativas da iniciativa privada e das leis de livre mercado. A partir disso, se pode falar do uso corporativo do território, em que as empresas agirão no sentido de aplicar diferentes estratégias com vistas à acumulação de recursos e expansão das suas atividades territoriais e financeiras.

Nessa perspectiva, a desestatização das telecomunicações no Brasil teve como resultado direto a divisão das Telebrás em grandes holdings, organizadas no segmento de telefonia celular e de telefonia fixa local, uma vez que, anteriormente, a Telebrás era uma:

[...] empresa holding de um sistema empresarial constituído de 27 (vinte e sete) operadoras estaduais e de 1 operadora de longa distância, bem como de dois centros de treinamento (em Recife e em Brasília) e de 1 (um) Centro de Pesquisa e de Desenvolvimento, era 
a responsável por mais de 95\% dos serviços públicos de telecomunicações do País. ${ }^{16}$

Já a aprovação para divisão da Telebrás ocorreu em abril de 1998 e o leilão em 29 de julho de 1998. Assim, as tabelas 1 e 2 auxiliam a melhor elucidar esse assunto ao expor os vencedores do leilão do sistema Telebrás para a telefonia fixa e celular, bem como para as empresas espelho na telefonia convencional e os mapas 1, 2 e 3 complementam tais tabelas ao exporem em termos espaciais o resultado desse processo e, por conseguinte:

Simbolicamente, a martelada do leiloeiro Alexandre Runte, na Bolsa de Valores do Rio de Janeiro, em 29.07.98, liquidou a privatização da Telebrás por um valor de $\mathrm{R} \$ 22,05$ bilhões, obtendo um ágio médio de $63,74 \%$. O ágio médio para as operadoras da telefonia fixa foi de $30,6 \%$, e o da telefonia celular, de $200,66 \%$. O menor ágio foi pago exatamente pelo consórcio Telemar (de 1\%), articulado na última hora pelo BNDES. (Dalmazo, 2002, p.274)

Dalmazo (2002, p.274) relatou ainda que os investidores estrangeiros controlavam nove operadoras após o leilão com investimentos de $\mathrm{R} \$ 15,8$ bilhões de reais, o que equivalia a aproximadamente $60 \%$ dos lances e o restante ficava com os grupos nacionais. Grupos esses que tinham pessoas chave como Pérsio Arida e Daniel Dantas, vinculados ao Banco Opportunity e a determinados fundos de pensão sua ação no leilão, arrematando fatias na Tele Norte Celular, Telemig e Tele Centro Sul.

Já outros como "[...] Globopar e o Bradesco confirmaram posição de vencedor, controlando $50 \%$ da Tele Celular Sul e da Tele Nordeste Celular apesar da derrota na telefonia fixa [...]” (Dalmazo, 2002, p.280). Derrota na telefonia fixa, porque perderam em São Paulo para a proposta agressiva da Telefónica e seu consórcio que arrematou a Telesp.

16 (Disponível em: <www.telebras.com.br/inst/?page_id=41>. Acesso em 21 set. 2015) 
Tabela 1 - Os vencedores do leilão do Sistema Telebrás na telefonia fixa e celular, 1998.

\begin{tabular}{|c|c|c|}
\hline Empresa & $\begin{array}{c}\text { Consórcio vencedor e percentual de } \\
\text { participação }\end{array}$ & $\begin{array}{l}\text { Origem do } \\
\text { capital }\end{array}$ \\
\hline $\begin{array}{l}\text { Telesp Participações } \\
\text { S/A }\end{array}$ & $\begin{array}{c}\text { Telefónica de España } \mathrm{S} / \mathrm{A}-56,6 \% \\
\text { Iberdrola }-7 \% \\
\text { Bilbao Viscaya }-7 \% \\
\text { Portugal Telecom }-23 \% \\
\text { RBS Part. AS }-6,4 \%\end{array}$ & $\begin{array}{l}\text { Espanha } \\
\text { Espanha } \\
\text { Espanha } \\
\text { Portugal } \\
\text { Brasil }\end{array}$ \\
\hline $\begin{array}{c}\text { Tele Centro Sul } \\
\text { Participações S/A }\end{array}$ & $\begin{array}{c}\text { Telecom Itália }-81 \% \\
\text { Fundos Previ e Sistel e Banco } \\
\text { Opportunity }-19 \%\end{array}$ & $\begin{array}{l}\text { Itália } \\
\text { Brasil }\end{array}$ \\
\hline $\begin{array}{l}\text { Tele Norte Leste } \\
\text { Participações S/A }\end{array}$ & $\begin{array}{c}\text { BNDESpar - 25\% } \\
\text { Flago (La Fonte) }-19,9 \% \\
\text { Andrade Gutierrez - 11,27\% } \\
\text { Macal - } 11,27 \% \\
\text { Grupo Inepar }-11,27 \% \\
\text { L.F. Tel - 11\% } \\
\text { BB Companhia de Seguros Aliança - 5\% } \\
\text { BB Brasil Veículos - 5\% } \\
\text { Rivoli - } 0,27 \%\end{array}$ & $\begin{array}{l}\text { Brasil } \\
\text { Brasil } \\
\text { Brasil } \\
\text { Brasil } \\
\text { Brasil } \\
\text { Brasil } \\
\text { Brasil } \\
\text { Brasil } \\
\text { Brasil }\end{array}$ \\
\hline Embratel & MCI - 100\% & EUA \\
\hline $\begin{array}{c}\text { Telesp Celular } \\
\text { Participações S/A }\end{array}$ & Portugal Telecom - 100\% & Portugal \\
\hline $\begin{array}{l}\text { Tele Sudeste Celular } \\
\text { Participações S/A }\end{array}$ & $\begin{array}{c}\text { Telefónica }-92,98 \% \\
\text { Iberdrola }-6,98 \% \\
\text { NTT Mobile }-0,02 \% \\
\text { Itochu Corporation }-0,02 \%\end{array}$ & $\begin{array}{l}\text { Espanha } \\
\text { Espanha } \\
\text { Japão } \\
\text { Japão }\end{array}$ \\
\hline $\begin{array}{l}\text { Telemig Celular } \\
\text { Participações S/A }\end{array}$ & $\begin{array}{c}\text { Telesystems }-48 \% \\
\text { Fundos (Previ e Sistel) - 24\% } \\
\text { Banco Opportunity - } 21 \% \\
\text { Outros }-13 \% \\
\end{array}$ & $\begin{array}{l}\text { Canadá } \\
\text { Brasil } \\
\text { Brasil } \\
\text { Brasil }\end{array}$ \\
\hline $\begin{array}{c}\text { Tele Celular Sul } \\
\text { Participações S/A }\end{array}$ & $\begin{array}{c}\text { UGB Participações (Globo e Bradesco) } \\
-48,2 \% \\
\text { Bitel Participações (Telecom Itália) - } \\
51,8 \%\end{array}$ & $\begin{array}{l}\text { Brasil } \\
\text { Itália }\end{array}$ \\
\hline $\begin{array}{c}\text { Tele Nordeste } \\
\text { Celular Participações } \\
\text { S/A }\end{array}$ & $\begin{array}{c}\text { UGB Participações (Globo e Bradesco) } \\
-48,2 \% \\
\text { Bitel Participações (Telecom Itália) } \\
-51,8 \%\end{array}$ & $\begin{array}{l}\text { Brasil } \\
\text { Itália }\end{array}$ \\
\hline $\begin{array}{l}\text { Tele Leste Celular } \\
\text { Participações S/A }\end{array}$ & $\begin{array}{l}\text { Iberdrola Energin - } 62 \% \\
\text { Telefónica }-38 \%\end{array}$ & $\begin{array}{l}\text { Espanha } \\
\text { Espanha }\end{array}$ \\
\hline
\end{tabular}




\begin{tabular}{c|c|c}
\hline $\begin{array}{c}\text { Tele Centro Oeste } \\
\text { Celular Participações } \\
\text { S/A }\end{array}$ & Bid S/A (Spice do Brasil)-100\% & Brasil \\
\hline Tele Norte Celular & Telesystems International Wireless & Canadá \\
Participações S/A & Inc. $-48 \%$ & Brasil \\
& Fundos Sistel e Previ $-18 \%$ & Brasil \\
& Banco Opportunity $-21 \%$ & \\
\hline CRT Celular & Outros $-13 \%$ & Espanha \\
& Telefónica de España e as coligadas & Brasil \\
& CTC, Tasa e Citicorp - $83 \%$ & \\
\hline
\end{tabular}

Fonte: Extraído de Dalmazo (2000, p.282-283). Reconfigurado por Jurado da Silva (2012).

Tabela 2 - As empresas espelho na telefonia convencional no Brasil, 1998.

\begin{tabular}{|c|c|c|}
\hline $\begin{array}{c}\text { Área de } \\
\text { concessão }\end{array}$ & $\begin{array}{c}\text { Consórcio Vencedor e } \\
\text { Percentual }\end{array}$ & Origem do Capital \\
\hline $\begin{array}{c}\text { Região I } \\
\text { (RJ, MG, ES, } \\
\text { BA, SE, AL, PE, } \\
\text { PB, RN, CE, PI, } \\
\text { MA, PA, AP, } \\
\text { AM, } \\
\text { RR) }\end{array}$ & $\begin{array}{c}\text { Canbrá (Vésper) } \\
\text { Bell Canadá - 34,4\% } \\
\text { Qualcomm - 16,25\% } \\
\text { WLL Internacional - 34,4\% } \\
\text { SLI Wireless - 12,5\% } \\
\text { Taquari Participações (Grupo } \\
\text { Vicunha) - 2,5\% }\end{array}$ & $\begin{array}{l}\text { Canadá } \\
\text { EUA } \\
\text { EUA } \\
\text { Argentina } \\
\text { Brasil }\end{array}$ \\
\hline $\begin{array}{c}\text { Região II } \\
\text { (DF, RS, SC, PR, } \\
\text { MS, MT, GO, } \\
\text { TO, RO, AC) }\end{array}$ & $\begin{array}{c}\text { Global Village Telecom } \\
\text { Global Village Telecom } \\
\text { (Magnum, Merril Lynck, Gilat } \\
\text { Satellite Networks e Clal) - 78\% } \\
\text { Com Tech - 20\% } \\
\text { RSL Communications - 2\% }\end{array}$ & $\begin{array}{l}\text { Israel / Holanda } \\
\text { EUA } \\
\text { EUA }\end{array}$ \\
\hline $\begin{array}{l}\text { Região III } \\
\quad(\mathrm{SP})\end{array}$ & $\begin{array}{c}\text { Megatel (Vésper São Paulo) } \\
\text { Bell Canadá - 34,4\% } \\
\text { Qualcomm - 16,25\% } \\
\text { WLL Internacional - 34,4\% } \\
\text { SLI Wireless - 12,5\% } \\
\text { Taquari Participações (Grupo } \\
\text { Vicunha) - 2,5\% } \\
\end{array}$ & $\begin{array}{l}\text { Canadá } \\
\text { EUA } \\
\text { EUA } \\
\text { Argentina } \\
\text { Brasil }\end{array}$ \\
\hline $\begin{array}{c}\text { Região IV } \\
\text { Todo o território } \\
\text { nacional }\end{array}$ & $\begin{array}{c}\text { Intelig } \\
\text { Sprint }-25 \% \\
\text { France Telecom }-25 \% \\
\text { The National Grid }-50 \%\end{array}$ & $\begin{array}{c}\text { EUA } \\
\text { França } \\
\text { Inglaterra }\end{array}$ \\
\hline
\end{tabular}

Fonte: Extraído de Dalmazo (2000, p.289). Reconfigurado por Jurado da Silva (2012). 
PAULO FERNANDO JURADO DA SILVA
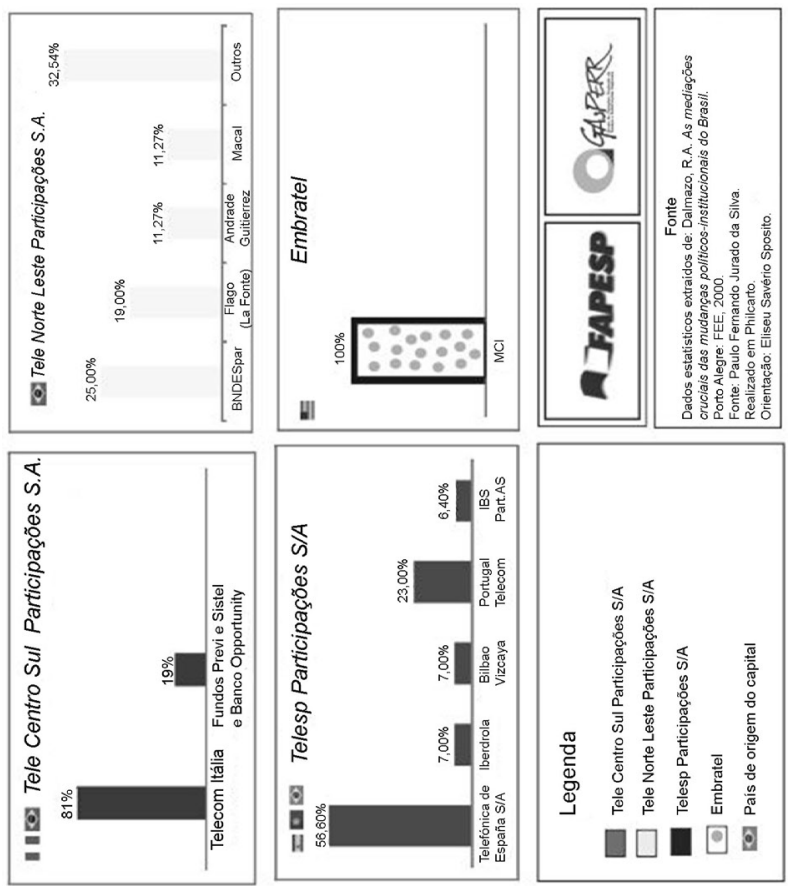

文
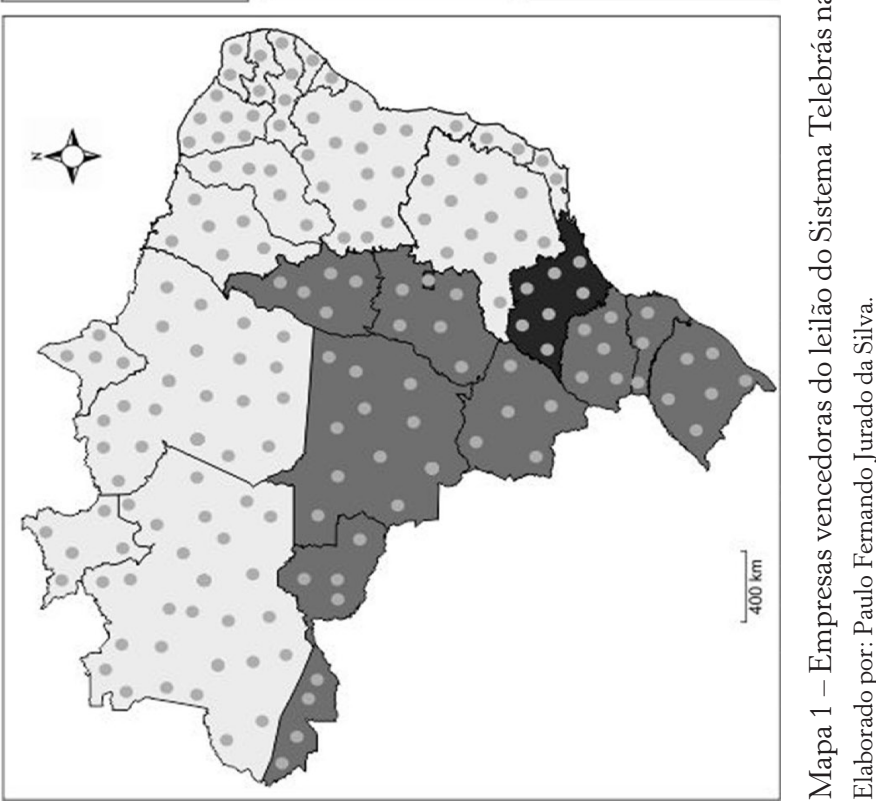


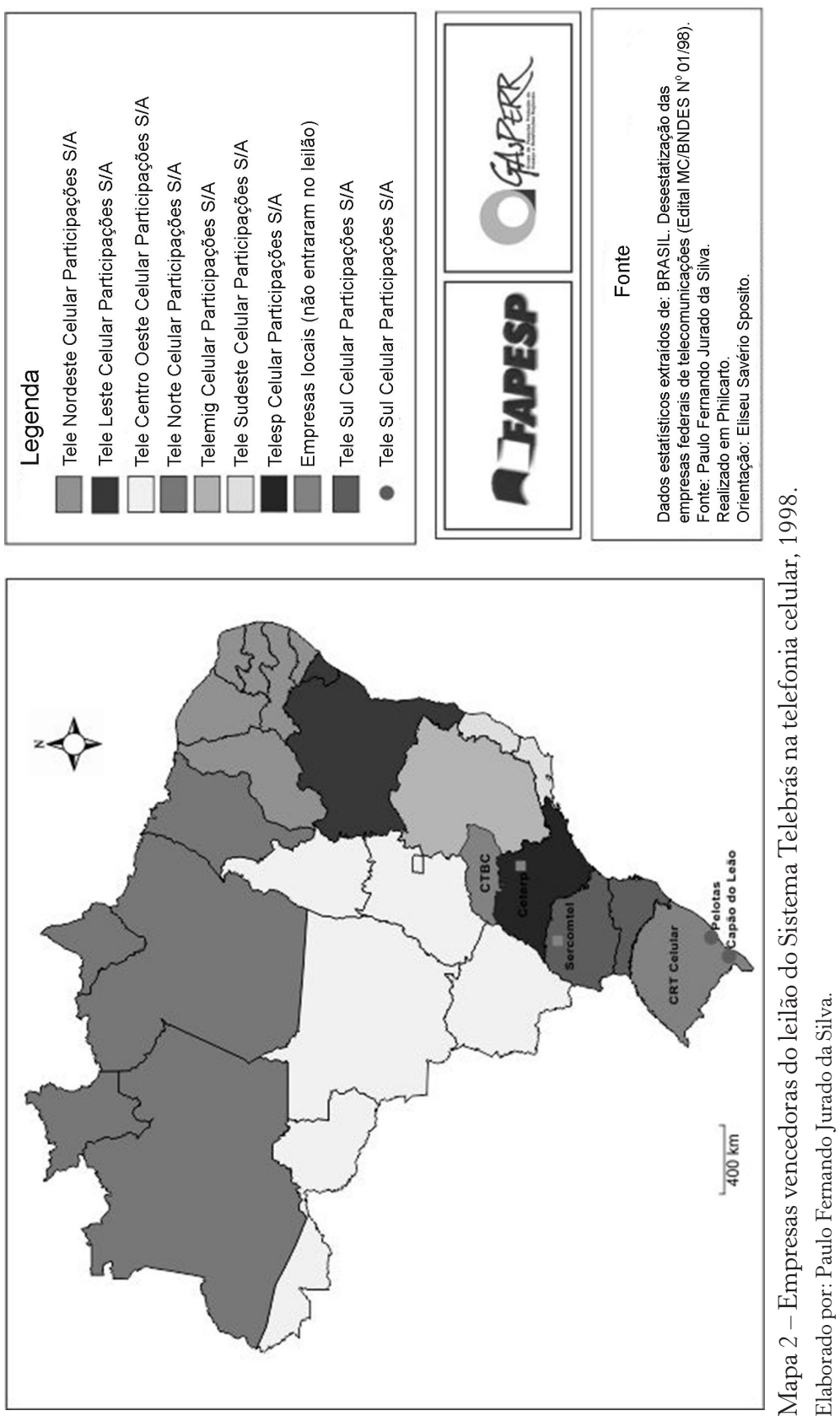



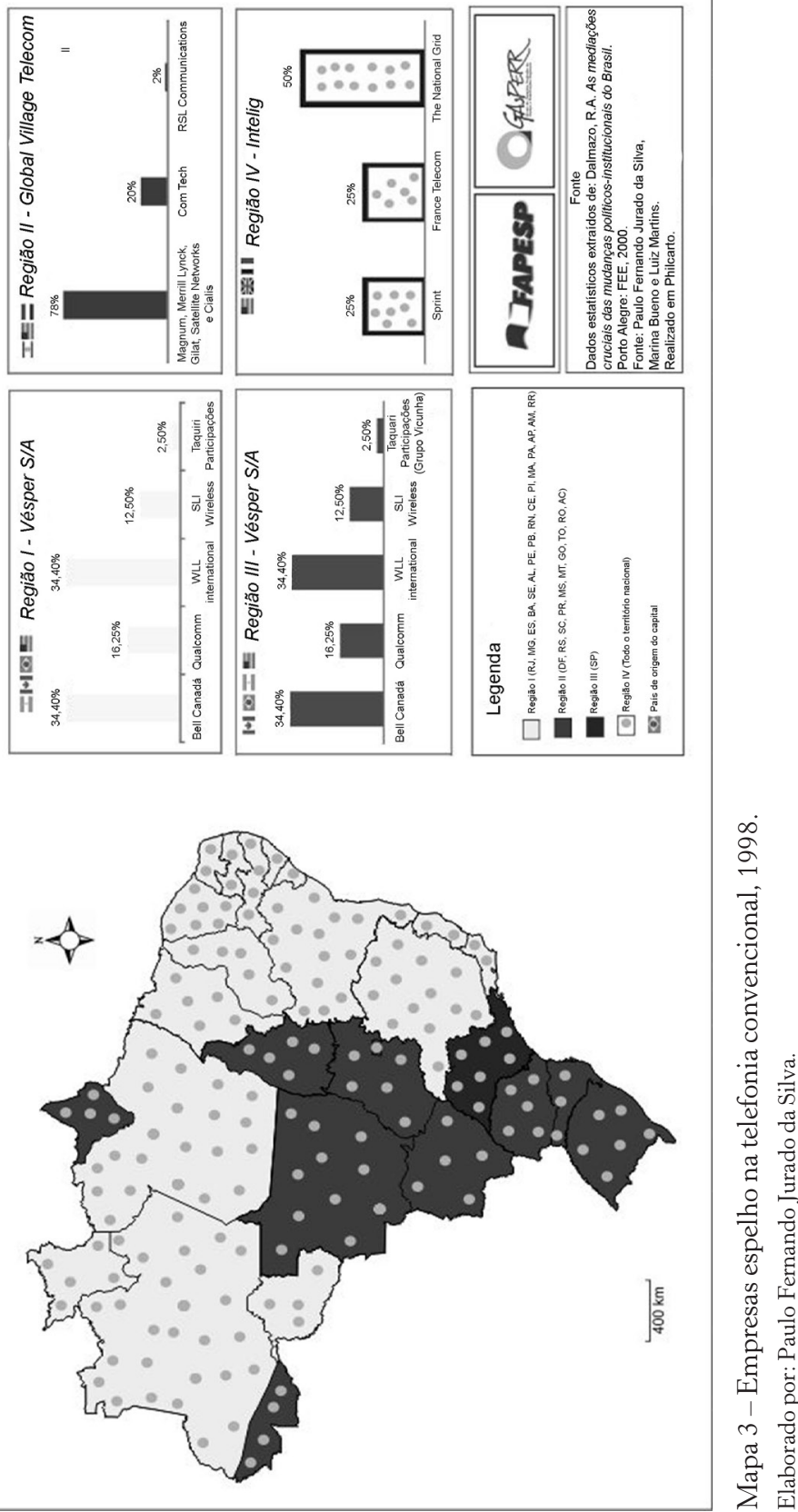
Além disso, tal leilão levou em conta uma regionalização do território baseada na rentabilidade que essas frações espaciais poderiam render às corporações e não foram condizentes à Geografia vivenciada pela população e aos anseios da sociedade. Nas palavras de Tozi (2005, p.48):

Criou-se uma regionalização descolada da realidade concreta do país, das suas desigualdades e necessidades, ou, melhor dizendo, das necessidades essenciais da vida, uma vez que consideramos que dadas as condições do momento histórico, comunicar-se e informar-se é uma necessidade básica, um desejo e um direito a ser realizado pelo Estado. Contudo, na prevalência da privatização, a necessidade de comunicação é imposta aos lugares e às pessoas. $\mathrm{O}$ "falso", diz Santos (2002 [1978]), é imposto como uma adição ao "necessário", como resposta ao interesse de alguns.

$\mathrm{Na}$ tentativa de melhor ilustrar essa regionalização proveniente do leilão do Sistema Telebrás, os mapas e as tabelas auxiliam a visualizar essa questão. O Mapa 1 é a espacialização da Tabela 2, na telefonia fixa, no que diz respeito às empresas vencedoras do leilão do Sistema Telebrás, efetuado em 1998. Nele, é possível verificar que a Tele Centro Sul S.A. abocanhou parcela considerável do serviço no Brasil, bem como a Tele Norte Leste Participações S.A.

A Tele Centro Sul foi um grupo formado a partir da ação majoritária da Telecom Itália (81\%) que é a controladora da atual TIM no Brasil em parceria com os Fundos Previ, Sistel e Banco Opportunity com 19\%, mostrando um nítido inter-relacionamento entre o capital nacional e internacional. A Tele Norte Leste Participações, por sua vez, tinha uma composição nacional, tendo a participação do BNDESpar (25\%), Flago (19\%), Andrade Gutierrez (11,27\%), Macal $(11,27)$ e demais grupos com participação menor que juntos 
compunham 35,24\% de participação, sendo depois essa companhia incorporada pela OI S.A. ${ }^{17}$

Já a Telesp Participações S. A. no Estado de São Paulo constituía a parte mais valiosa do leilão, sendo adquirida por grupos de origem espanhola, portuguesa e brasileira, sendo eles: Telefónica de España (56,60\%), Iberdrola (7\%), Bilbao Viscaya (7\%), Portugal Telecom (23\%) e RBS Part. (6,4\%), dando origem posteriormente à Telefônica, que depois passou a se chamar Vivo, em uma ação integrada na telefonia fixa, celular, internet e televisão por assinatura, no período atual. Logo, o relacionamento do capital nacional e internacional também foi visível nessa ação, na qual a RBS, vinculada às Organizações Globo, no Sul do país, teve um papel importante. Mas, é claro que ao longo da história essa composição acionária foi sendo alterada e o grupo Telefónica paulatinamente dominando o cenário de competição da companhia.

Por sua vez, a única empresa, naquela ocasião, presente em todo o território nacional e que fazia a interconexão de diferentes regiões era a Embratel que foi comprada integralmente pelo grupo estadunidense MCI e depois vendida para a América Móvil.

Portanto, na telefonia fixa, observa-se que foram asseguradas três regiões para exploração corporativa das empresas de modo direto e exclusivo, fazendo com que não houvesse competição elas mesmas nesse momento inicial da privatização do território. Só a Embratel tinha ação em uma camada superior, ou seja, o território nacional. Essa estratégia do governo brasileiro assegurou a essas empresas a exploração de frações importantes do território dando a elas garantias de lucro certo. Além disso, pelo Plano Geral de Outorgas, tais companhias não poderiam transpor seus territórios de atuação, operando em mais de uma região leiloada, sendo essas empresas denominadas concessionárias e reguladas pela Anatel.

Tal modelo de leilão teve como resultado geográfico a produção de desigualdades socioespaciais, acompanhadas pela distribuição

17 Disponível em: <www.valor.com.br/empresas/2544496/tele-norte-leste-participacoes-aprova-incorporacao-pela-futura-oi-sa>. Acesso em: 21 set. 2015. 
de diferentes empresas privadas no país e com forte internacionalização do capital e, dessa maneira, “[...] operadoras ocupam monopolisticamente fragmentos do mercado e compartilham umas com as outras o acesso a cada fragmento, assim ganhando todas" (Dantas, 2002, p.53).

Às áreas que não houvesse de certa maneira maior rentabilidade com uso do território, o Estado entrou com parte do capital necessário para viabilização do processo de privatização, a exemplo do que ocorreu na Região I com a Tele Norte Leste com a compra de $25 \%$ do capital votante pelo Banco Nacional de Desenvolvimento Econômico e Social (BNDES), obrigando as empresas que atuassem em Estados como Minas Gerais e Rio de Janeiro a operarem igualmente nas regiões Norte e Nordeste do país, como considerou Tozi (2009, p.25).

Já no leilão da telefonia celular verifica-se de acordo na Tabela 2 e no Mapa 2 uma maior presença de consórcios participantes. Algumas áreas no país já tinham a especificidade de serem operadas por empresas locais estatais ou já privatizadas anteriormente ao leilão da Telebrás. Era o caso da CRT Celular no território do Rio Grande do Sul, da Sercomtel em Londrina, da Ceterp em Ribeirão Preto e da CTBC no Triângulo Mineiro.

A CRT (Companhia Riograndense de Telecomunicações) ${ }^{18}$ foi uma companhia estatal. Criada por Leonel Brizola na década de 1960, foi o resultado da incorporação da estadunidense International Telephone and Telegraph Corporation (ITTC) e que depois foi privatizada na década de 1990, passando para o domínio de outros grupos.

A Sercomtel (Serviço de Comunicações Telefônicas de Londrina $)^{19}$ foi criada originalmente em Londrina como uma autarquia. Atualmente, opera não somente no âmbito de Londrina, mas em várias cidades de sua região de influência, oferecendo servi-

18 Disponível em: < www.pdtrs.org.br/todos-os-artigos/252-brizola-e-a-crt>. Acesso em: 21 set. 2015.

19 Disponível em: < www.sercomtel.com.br/portalSercomtel/empresa.home. do>. Acesso em: 21 set. 2015. 
ços como telefonia fixa e celular, internet e televisão por assinatura. A Ceterp (Centrais Telefônicas de Ribeirão Preto), por sua vez, foi uma empresa criada no âmbito municipal pela prefeitura, sendo comprada pela Telefônica na década de 1990.

Já a CTBC (Companhia de Telefone do Brasil Central - Algar Telecom) é uma operadora controlada pelo grupo Algar no Triângulo Mineiro. Atualmente possui capital aberto e opera em São Paulo, Rio de Janeiro, Goiás, Distrito Federal, Mato Grosso do Sul e Paraná, oferecendo telefonia fixa e celular, internet, TV paga e comunicação de dados com uma base de oitocentos mil clientes. ${ }^{20}$

O restante do território foi leiloado para 8 companhias distintas, a saber: a Tele Nordeste Celular (Piauí, Pernambuco, Alagoas, Paraíba, Rio Grande do Norte e Ceará), Tele Leste Celular (Bahia, Sergipe), Tele Centro Oeste (Mato Grosso, Mato Grosso do Sul, Goiás, Distrito Federal, Rondônia e Acre), Tele Norte Celular (Amazônia, Pará, Amapá, Roraima e Maranhão), Telemig Celular (Minas Gerais), Tele Sudeste Celular (Rio de Janeiro e Espírito Santo), Telesp Celular (São Paulo) e Tele Sul Celular (operando em Pelotas e Capão do Leão no Rio Grande do Sul, Paraná e Santa Catarina).

No campo das empresas espelho, verifica-se que estas não são concessionárias, sendo companhias autorizadas a operarem no território nacional, nas faixas das quais adquirirem, podendo concorrer com as empresas concessionárias em suas respectivas áreas de atuação. As concessionárias são as herdeiras do sistema Telebrás, enquanto as autorizadas (empresas espelho) têm que começar a atividade com a implantação no território das infraestruturas necessárias para oferecer seus serviços e, com isso, podem praticar tarifas de acordo com as leis de mercado, diferentemente das concessionárias.

Em termos geográficos, as concessionárias se utilizam das redes-suporte instaladas previamente no território pela ação estatal para manipular sua estratégia corporativa de redes-serviço, enquanto as autorizadas têm que produzir territorialmente redes-suporte para

20 Disponível em Algar Telecom: < www.algartelecom.com.br/section.do?Cod$\mathrm{Sec}=13952>$. Acesso em: 21 set. 2015. 
daí então estruturar suas redes-serviço e difundir sua atuação e estratégia, tendo como parâmetro teórico Curien e Gensollen (1985). Nesse caso, é válido ressaltar que as concessionárias têm um contrato de 25 anos estabelecidos com o governo para operarem em sua respectiva região. Entretanto, sobre esse quadro Tozi (2005, p.80) alertou para o fato de que:

[...] as empresas concorrentes - espelhos - não possuem, inicialmente, clientes e tampouco constroem uma nova rede. Assim, sem redes concorrentes, não pode haver concorrência entre as empresas; além disso, as empresas espelhos utilizam as redes das outras operadoras com as quais deveriam concorrer.

Ademais, sobre o assunto da privatização do território Tozi (2005, p.35) escreveu que: "[...] o objetivo da empresa privada é o lucro, o território privatizado é um recurso das políticas individuais das empresas, amparadas por um Estado descompromissado das questões sociais." e completa, mais adiante, seu raciocínio quando argumentou que:

A privatização atribui aos grupos privados - o "capital 'piranha' nacional e internacional”, segundo Maria Conceição Tavares (1998) - o poder de controle sobre boa parte do funcionamento dos sistemas técnicos e dos serviços, reduzindo a capacidade de ação estatal sobre eles. Enquanto o Estado deveria se preocupar com todos os cidadãos - o que de fato nunca fez - as empresas preocupam-se consigo mesmas e quiçá com seus clientes e não poderão, nunca, realizar a função de serem as responsáveis pela distribuição, no sentido da eqüidade sócioterritorial, dos objetos e dos serviços, o que contrariaria o seu próprio sentido de existência. (Tozi, 2005, p.36)

Nomenclaturas à parte (concessionárias/autorizadas/permissionárias), essas estratégias do uso do território se revelaram na sua privatização, em sentido mais amplo, instalando uma competitividade territorial que, pelo menos no momento, pouco diferencia em 
termos de tarifas as operadoras em um mercado controlado pela ação de grandes grupos, na forma de oligopólios, como será defendido mais adiante, no último capítulo.

Assim, no campo das empresas espelho, a Intelig competia com a Embratel (concessionária), ocupando a Região IV no Mapa 4, sendo seu capital composto por investimentos estadunidense, inglês e francês. Além disso, consultando o Mapa 3 e a Tabela 2 verifica-se que além da Região IV, delimitada pelo plano de operação nacional, que há ainda mais três regiões de operação pelas empresas espelho, sendo essas resumidamente:

a. Região I: vencida pelo consórcio Vésper - Canbrá - tem a presença do capital canadense, americano, argentino e brasileiro com o investimento maior da Bell Canadá e da WLL Internacional com 34,4\% cada uma. A área de operação compreendia os estados de Minas Gerais, Rio de Janeiro, Espírito Santo, Bahia, Sergipe, Pernambuco, Alagoas, Paraíba, Ceará, Rio Grande do Norte, Piauí, Maranhão, Pará, Amapá, Amazonas e Roraima.

b. Região II: adquirida pela Global Village Telecom contava com investimentos de Israel, Holanda e Estados Unidos e com o maior capital para as empresas Magnum, Merril Lynck, Gilat Satellite Networks e Clal, correspondendo juntas ao total a 78\% da composição acionária do consórcio. A Global, por sua vez, tinha como área de operação os Estados de Rio Grande do Sul, Santa Catarina, Paraná, Mato Grosso do Sul, Mato Grosso, Goiás e Distrito Federal, Tocantins, Rondônia e Acre.

c. Região III: comprada pela Megatel (Vésper São Paulo) correspondia aos investimentos pela Bell Canadá e WLL Internacional com $34,4 \%$ e outros grupos com participação menor para operar no território paulista. 
Hoje, a Vésper ${ }^{21}$ pertence à Embratel e a Global Village Telecom é conhecida como GVT, oferecendo os serviços de TV por assinatura, internet e telefonia. A $\mathrm{GVT}^{22}$ que durante certo tempo foi controlada pela Vivendi foi adquirida recentemente no Brasil pelo Grupo Telefónica e a Intelig foi comprada pela Tim, vinculada à Telecom Itália.

Por conseguinte, no país, desse novo marco regulatório em diante pode-se compreender as telecomunicações estruturadas em três grandes segmentos de abrangência conforme o Quadro 5.

Haveria, nessa perspectiva, os serviços de telecomunicações que representam as empresas concessionárias e com autorização para a exploração dos serviços de telecomunicações; o segmento dos produtos e serviços para as prestadoras de serviços que são, em geral, fornecedores de equipamentos para as empresas que atuam nos serviços de telecomunicações; e, por fim, o segmento de valor agregado que é representado pelas empresas que prestam serviços e suportam as telecomunicações no território brasileiro.

Quadro 5-Segmentos das telecomunicações conforme a atuação dos agentes privados.

\begin{tabular}{|c|c|}
\hline Segmentos & Agentes Privados \\
\hline $\begin{array}{c}\text { Serviços de } \\
\text { Telecomunicações }\end{array}$ & $\begin{array}{c}\text { Empresas que detém concessão ou autorização para } \\
\text { a prestação de serviços, tais como Telefonia Fixa, } \\
\text { Comunicações Móveis, Comunicação Multimídia, }\end{array}$ \\
\hline $\begin{array}{c}\text { Produtos e serviços } \\
\text { para as Prestadoras } \\
\text { de Serviços de } \\
\text { Telecomunicações }\end{array}$ & $\begin{array}{c}\text { Fornecedores de equipamentos e prestadores de } \\
\text { serviço que dão suporte à prestação de serviços de } \\
\text { Telecomunicações, inclusive fornecedores de } \\
\text { capacidade espacial. }\end{array}$ \\
\hline $\begin{array}{c}\text { Serviços de Valor } \\
\text { Agregado }\end{array}$ & $\begin{array}{c}\text { Empresas prestadoras de serviços que têm como suporte } \\
\text { principal serviços de telecomunicações. }\end{array}$ \\
\hline
\end{tabular}

Fonte: Associação Brasileira de Telecomunicações (Telebrasil) e Teleco (2006), extraído de Ferreira (2007, p.90) e reconfigurado por Jurado da Silva (2012).

21 Disponível em: < www.embratel.com.br/Embratel02/files/dc/01/02/ Vesper\%20Concl\%20PRPor.PDF>. Acesso em: 21 set. 2015.

22 Disponível em: < www.gvt.com.br/PortalGVT/Institucional>. Acesso em: 21 set. 2015. 
Assim, se pensado esse quadro dos segmentos das telecomunicações de forma mais ampla e sintética, acrescendo-se o papel do Estado como ente regulador, poderia se destacar, segundo a Lei Geral das Telecomunicações, que há dois regimes jurídicos que orientam o setor no Brasil, sendo o público, que tem como função garantir e cobrar a universalização, continuidade do sistema e a qualidade dos serviços prestados pelas empresas, e um segundo de caráter privado, que deve obedecer às normativas constitucionais desse tipo de atividade econômica.

Além disso, haveria duas categorias quanto à prestação dos serviços, sendo os serviços de interesse restrito executados pela iniciativa privada e os serviços de interesse coletivo operados tanto pelo poder público quanto privado. Os serviços de caráter público são prestados por meio de concessões e permissões e os de caráter privado prestados por meio de autorizações da Anatel, que é a agência reguladora do setor no Brasil. Nesse sentido, vale ressaltar que as empresas que venceram o leilão da Telebrás têm contratos de concessão com o Estado por meio da aprovação da Anatel. Além disso, em 2003, houve algumas alterações em algumas das cláusulas desse processo e os contratos renovados com vigência estipulada de 2006 a 2025.

Já a Telebrás, que no passado passou por um processo de cisão e privatização, passa a ter um papel de destaque somente em 2010, sob a égide do Governo Lula. Nesse contexto, foi criado o Plano Nacional de Banda Larga - PNBL - visando estimular o acesso à internet por meio da população brasileira e a Telebrás ficando autorizada conforme o artigo quinto ${ }^{23}$ desse decreto: “[... ] a usar, fruir, operar e manter a infraestrutura e as redes de suporte de serviços de telecomunicações de propriedade ou posse da administração pública federal".

Portanto, mediante a interpretação do quadro das telecomunicações no Brasil, verifica-se que a sua devida compreensão perpassa pelo estudo das empresas privadas e suas estratégias, bem como

23 Decreto disponível em < /www.planalto.gov.br/ccivil_03/_Ato20072010/2010/Decreto/D7175.htm>. Acesso em: 21 set. 2015. 
pelo papel do Estado como ente regulador do processo. Dessa maneira, há uma grande pulverização de corporações operando e com diferentes territórios que às vezes tendem a se sobrepor, dependendo da lógica de atuação das mesmas.

A Geografia, nesse cenário, tem total importância para revelar as contradições desse processo, descrever a relação dessas empresas no uso do território e expor de forma clara os interesses envolvidos na busca pela ampliação do lucro. Os interesses tendem a ser os mais variados possíveis, demonstrando competitividade pelo acesso às inovações disponíveis no mercado, embora os serviços prestados ainda sejam alvo de muitas reclamações por parte dos consumidores que se sentem, em alguns casos, lesados por essas empresas que atuam no território nacional e oferecem produtos e serviços, que algumas vezes ficam aquém do esperado.

No dia 23 de julho de 2012, por exemplo, a Anatel, tendo em vista o grande número de reclamações contra algumas operadoras no país, proibiu a venda de determinados serviços por parte dessas, excluindo dessa punição Vivo, Sercomtel e CTBC, por exemplo. Assim, sinteticamente, o portal R7 descreveu as punições das operadoras em termos espaciais naquele momento quando publicou que:

A operadora mais punida foi a TIM, impedida de comercializar novas linhas e internet em 19 Estados: Acre, Alagoas, Bahia, Ceará, Distrito Federal, Espírito Santo, Goiás, Maranhão, Minas Gerais, Mato Grosso, Pará, Paraíba, Pernambuco, Piauí, Paraná, Rio Grande do Norte, Rondônia e Tocantins, além do Rio de Janeiro.

As vendas da Oi estão vetadas em cinco Estados: Amazonas, Amapá, Mato Grosso do Sul, Roraima e Rio Grande do Sul.

Já a Claro está proibida de negociar chips e internet em Santa Catarina, Sergipe e São Paulo. (Disponível em: <http:// noticias.r7.com/economia/noticias/entenda-a-proibicao-da-venda-de-novas-linhas-de-celular-pela-anatel-20120728. html?question=0 $>$. Acesso em 21 set. 2015) 
Tal ação foi motivada em razão das:

[...] crescentes queixas dos consumidores em relação aos serviços dessas empresas, como atendimento deficiente aos clientes, falta de qualidade na cobertura ("sinal fraco") e interrupção no acesso à internet. $^{24}$

Por se comprometerem a efetuar adequações e melhorias aos seus serviços com o anúncio de investimentos por parte das operadoras, a Anatel liberou tais companhias para voltar a vender novamente seus produtos depois de alguns dias de proibição, uma vez que:

[...] apresentaram à agência planos de investimentos para solucionar os problemas na rede de telefonia móvel. De acordo com o presidente da Anatel, João Rezende, os planos apresentados somam $\mathrm{R} \$ 20$ bilhões nos próximos dois anos. ${ }^{25}$

Nesse sentido, e tendo o panorama da privatização do território como pano de fundo, que será apresentado no próximo capítulo a descrição do uso corporativo pelas principais empresas de telecomunicação no país. Com isso, é cada vez mais marcante a inserção de agentes e companhias de capital estrangeiro nesse setor que tem apresentado constante transformação, dinamicidade acionária, capital, influência política, econômica e cultural no contexto da produção e uso do território brasileiro.

24 (Disponível em: <http://noticias.r7.com/economia/noticias/entenda-a- proibicao-da-venda-de-novas-linhas-de-celular-pela-anatel-20120728. html?question=0>. Acesso em 21 set. 2015).

25 (Disponível em: <http://g1.globo.com/jornal-hoje/noticia/2012/08/operadoras-punidas-pela-anatel-voltam-vender-linhas-de-celular.html>. Acesso em: 21 set. 2015). 


\section{3 \\ OS ATUAIS USOS CORPORATIVOS DO TERRITÓRIO PELAS EMPRESAS DE TELECOMUNICAÇÕES NO BRASIL}

\section{Telecomunicações e uso corporativo do território}

As telecomunicações ao longo do tempo serviram a diferentes objetivos do Estado, bem como estiveram articuladas às políticas territoriais, desempenhadas no processo de uso e domínio da técnica. Compreende-se, desse modo, o seu papel fundamental como infraestrutura necessária para o desenvolvimento da nação, mas também para articular diferentes partes do território e levar no processo de comunicação a informação, imprescindível elemento na dinâmica econômica social capitalista contemporânea.

Os dados do setor demonstram cada vez mais vitalidade, tendo crescimento importante na composição do Produto Interno Bruto do país. Assim, tendo em vista o relatório produzido pela Associação Brasileira de Telecomunicações, em parceria com o Teleco, divulgado em dezembro de 2012 para os nove primeiro meses do referido ano, é possível destacar que:

No final dos nove meses de 2012, os serviços de telecomunicações eram prestados para 341,6 milhões de assinantes, um aumento de 13,1\% em relação aos 302,1 milhões do final dos nove meses de 
2011; os 341,6 milhões são compostos por (crescimento em relação a igual período de 2011):

- 43,7 milhões com o Serviço Telefônico Fixo Comutado (2,3\%);

- 258,9 milhões com o Serviço de Comunicações Móveis (Celulares) (13,9\%);

- 15,4 milhões com o Serviço de TV por Assinatura (29,5\%);

- 19,4 milhões com o Serviço de Acesso Fixo à Internet Banda Larga (19,8\%).

- 4,2 milhões com o Serviço Móvel Especializado (trunking) $(5,7 \%)$.

(Disponível em: <www.telebrasil.org.br/> . Acesso em: 21 set. 2015)

Desses dados pode-se destacar a magnitude e a abrangência das telecomunicações no Brasil, onde o serviço de comunicação móvel, por exemplo, cresce mais do que a telefonia fixa. Já o serviço de TV por assinatura foi o setor que ganhou maior crescimento para o período em análise, em relação às demais tecnologias, se aproximando aos números absolutos dos dados do serviço de acesso fixo à internet banda larga.

Não é novidade, pois, o argumento do crescimento do setor, mas é fato que este se encontra em transformação, movido por diferentes formas de investimento privado e pela regulação estatal. Consequentemente, no momento atual, o Estado assumiu o papel de ente regulador por meio da ação política e administrativa da Anatel. Nesse sentido, o Estado perde a função de estimulador, modernizador, mantenedor e provedor do setor para assumir posição de regulador, monitor e fiscalizador dos serviços, prestados pelas operadoras privadas. Nesse sentido, passa de protagonista para uma posição coadjuvante na trama de relações que constroem o uso do território.

Para Raffestin (1993), por exemplo, há "atores paradigmáticos" e "atores sintagmáticos". Enquanto estes últimos correspondem a um nível específico de organização territorial com objetivos e políticas definidas, os paradigmáticos, simplificadamente, são o povo, a nação, não possuindo, muitas vezes, uma ação conjunta no uso do 
território do ponto de vista de uma estratégia coordenada. Grosso modo, os atores sintagmáticos seriam resumidos em categorias como igrejas, empresas, partidos políticos e Estado.

Dessa relação entre atores paradigmáticos e sintagmáticos poderia se acrescer a noção de que o território para os sintagmáticos é entendido como recurso passível de exploração. Já para os paradigmáticos é mais um abrigo, local da realização da vida e da identidade.

Além disso, é importante não perder de vista os conflitos no uso do território e, por vezes, tensões, como considerou Milton Santos (2001), destacando e explicando em seu trabalho expressões como horizontalidades e verticalidades.

Das verticalidades irradiam atores capazes de organizarem e destruírem a tessitura territorial e colocar de "cima para baixo" comandos, ordens, normas, tirania econômica, diretrizes jurídicas etc. Enquanto que das horizontalidades expressam-se laços de coesão e cooperação horizontal, de modo a promoverem a solidariedade e os interesses da sociedade civil e organizada.

Desse Estado internamente desigual e subordinado na globalização, em sentido geográfico surge a terminologia "alienação territorial”, como considerou Cataia (2001, p.218) quando afirmou, por exemplo que:

[...] a alienação dos territórios está ligada à forma como as populações se vêem envolvidas pela política das empresas. Se participar das decisões da política do Estado sempre foi um problema para a maioria dos brasileiros, participar da política das empresas está fora de questão.

Nessa perspectiva, é como se o destino e o controle da nação tivesse longe dos anseios do povo, mas embasado em campos de ação vertical, a exemplo dos organismos internacionais de crédito e das grandes corporações nos mais variados segmentos da economia. $\mathrm{O}$ território como marco das ações e estratégias das empresas é tomado, então, como ponto para a compreensão de um "uso corporativo do território". 
Uso corporativo do território porque leva em conta a ação do capital privado das grandes corporações que tem o poder econômico para participar de lógicas globalizadoras e globalizantes, em diferentes locais da produção da mais-valia e, por conseguinte:

[...] O Estado não se torna mínimo, mas flexível aos interesses do capital, que por sua vez é hegemônico, ganancioso e exigente, e assim "o Estado acaba por ter menos recursos para tudo o que é social" (Santos, 2000, p.66), ou seja, o "Estado, em nome da globalização e da reengenharia, abdica dos pobres e se volta totalmente para as empresas." (Souza, 1999, p..41) (Lopes, 2006, p.54)

Logo, o território para as empresas é objeto espacial para extração de lucro, es:

[... é o Estado, que no atual período histórico, colabora extensiva e sistematicamente com a política menor das grandes empresas, abrindo mão da política maior voltada ao povo, ao território e a sua soberania. (Lopes, 2006, p.55)

Nesse sentido, é válido frisar que as empresas ao se instalarem não fazem um uso neutro de suas estratégias de ganhos de renda e, portanto:

[...] a empresa não é mais localizada no "espaço recipiente" neutro ou indiferenciado da teoria neoclássica; ela se implanta num "meio socioeconômico mais ou menos integrado", quer dizer um território tornado mais ou menos atrativo graças aos recursos, aos potenciais, às oportunidades que ele propõe graças também a sua capacidade de adaptação às flutuações das necessidades de atividade econômica. (Fischer, 2008, p.61)

Nessa perspectiva, compreende-se que as estratégias das empresas se referem, genericamente, ao exame de suas ações no campo da exploração de condições que sejam favoráveis à política de expansão 
econômica e geográfica, inserindo essas operações no conjunto das políticas voltadas à dominação do território e com esses mecanismos:

[...] A empresa controla não somente todo aparelho de sua produção, que compreende seres e coisas, mas também controla, de uma forma mais indireta, os seres e as coisas por intermédio de seu ou de seus mercados. Quando entra em concorrência com outras empresas, coloca no balanço tudo ou parte de seus trunfos [...]. (Raffestin, 1993, p.59)

O território, nessa concepção, passa a ser visto como expressão de poder, normatizado e produzido por relações sociais que são, na realidade, resultantes da ação corporativa do domínio dos grupos econômicos, sejam eles nacionais ou internacionais, que lutam para obter maior influência, visibilidade, marca e controle no uso do território, bem como sobre as pessoas com a apropriação da mais-valia, consumo e endividamento.

Além disso, no contexto de investigação geográfica, a relação entre sociedade e natureza (entendida aqui enquanto espaço da realização da vida econômica e como recurso do capitalismo) deve passar pelo desvendamento das estratégias de incorporação e produção do território, que é, atualmente, cada vez mais, mediado pela informação, sistemas de comunicação e telecomunicação, potentes e complexos. Assim, é preciso ressaltar que tal quadro será tratado analiticamente nos itens subsequentes, ao abordar o assunto da TV por assinatura, internet e telefonia celular respectivamente.

\section{A televisão por assinatura}

A televisão por assinatura não se constitui tão somente no serviço a cabo de transmissão de imagem e som, mas se relaciona com outros tipos de serviços prestados. Em primeira instância, esse modelo de TV representou uma forma de assegurar a comunidades 
interioranas dos Estados Unidos o acesso à televisão com sinal de qualidade e, em um segundo momento, a possibilidade de segmentar de modo especializado, em diferentes estratos de programação, temas diversos como notícias, clipes, filmes, documentários, esportes etc.

Logo, o funcionamento da TV por assinatura se dá por meio de difusão por satélite nos formatos DTH (Direct to Home) e DBS (Direct Broadcast Satellite), micro-ondas que podem ser exploradas na forma de MMDS (Multipoint Multichannel Distribution Service) e UHF (Ultra High Frequency), codificado em cabo (cobre, coaxial, fibra etc.). Esses sistemas, por sua vez, são os mais utilizados no Brasil e representam a maior fatia de assinantes do segmento.

Sobre o assunto, Ramos e Martins (1995, p.140, grifo dos autores) auxiliaram a melhor elucidar tal quadro, quando escreveram que:

Mais precisamente, TV por Assinatura, é o serviço de comunicações que oferece a espectadores, através de qualquer um daqueles meios, programas selecionados, só passíveis de recepção mediante o pagamento de uma taxa de adesão e assinatura mensal. Um conversor, ou decodificador, acoplado ao aparelho de TV, é que vai permitir a recepção livre do sinal. Portanto, TV a Cabo é apenas uma modalidade de TV por Assinatura, na qual o transporte do sinal é feito, aí sim, por uma rede de cabos.

Tendo em vista esta descrição, a televisão por assinatura tem como estrutura funcional a segmentação variada de canais para parcelas selecionadas da sociedade, segundo seus estratos econômicos, interesses políticos, desportivos e culturais. Diferencia-se, portanto, da televisão aberta, destinada ao público em geral, constituída por canais que não são pagos. Ganha, com isso, a conotação de uma televisão fechada que no inglês se refere à Pay TV e no correspondente em português à TV paga ou TV por assinatura.

A televisão aberta no Brasil " [...] foi implantada no Brasil em 18 de setembro de 1950, quando entrou em funcionamento a PRF-3 TV Tupi-Difusora, Canal 3, em São Paulo, uma emissora dos Di- 
ários Associados de Assis Chateaubriand. [...]" (Carvalho, 2000, p.41), data essa anterior ao nascimento da televisão segmentada e paga. Mas, esse fato não seria obviamente possível caso não existisse uma topologia de sistemas de transmissão e retransmissão de imagens e som, sendo a difusão radioelétrica dos sinais captados pelas antenas nos imóveis dos telespectadores, seja em VHF (Very High Frequency), amplamente utilizada no país, seja em UHF (Ultra High Frequency) com menor disseminação.

Logo, a origem da televisão por assinatura está associada inicialmente à modalidade de televisão a cabo, por meio da sigla Community Antenna Television ou CATV nos Estados Unidos (Ramos; Martins, 1995). Isso significava, por exemplo, que uma comunidade que estivesse relativamente isolada, em uma área montanhosa ou em um terreno de difícil localização, pudesse ter acesso a um sistema de televisão com padrão de imagem e som de qualidade, com a instalação de antenas e estações que distribuíam o sinal por cabo às residências dos assinantes.

Além disso, o problema da recepção televisiva não ocorria somente em comunidades isoladas e, mesmo nos grandes centros entre arranha-céus, as imagens e o som algumas vezes chegavam de modo distorcido, demonstrando um amplo mercado a ser explorado. A CATV surgiu como reposta, portanto, às barreiras espaciais para levar a informação aos locais que antes não gozavam de plena integração à comunicação televisiva, ou se o faziam realizavam de modo precário.

Quando se passa a operar por satélites, a “onda” torna-se o paradigma principal das telecomunicações. A questão espacial passa a não ser mais um fator limitador para a comunicação, tornando-se recurso econômico para as empresas de telecomunicação faturar.

Logo, a comunicação em sentido fluído é transmitida a diferentes locais com distintos fusos horários. A informação ganha, nesse sentido, uma conotação de valor e de dinheiro, transmitindo ideias, comportamentos, interesses e costumes. Acerca dessa passagem histórica Torres (2005, p.54) descreveu que: 
Até a década de 1970 as empresas prestadoras de TV a cabo limitavam-se a distribuir a mesma programação transmitida gratuitamente por broadcast. Só em 1971 as empresas Teleprompter e Manhattan Cable iniciaram em Nova York a transmissão de programação que adicionava ao conteúdo do broadcast um conjunto de serviços gerados pelos operadores.

Essa inovação na forma de levar a informação televisiva a comunidades interioranas e afastadas dos grandes centros nos Estados Unidos revelou-se, então, em um excelente negócio, porque, além de sinal de TV, poderiam ser acopladas a oferta de canais locais e de programas diversos com uma variedade mais ampla que a TV aberta.

Nesse sentido, para Ramos e Martins (1995, p.142), por exemplo, dois fatos foram decisivos para a história da televisão por assinatura no momento inicial para sua ampliação e diversificação, a saber:

I) Em 1972 é lançado pela Time Life e pela Time Warner a Home Box Office (HBO) que trouxe para o mercado a exibição de diversos filmes da Warner Brothers pelo sistema via satélite, sem que a população precisasse sair de casa para assistir a um leque cinematográfico considerável.

II) A criação da CNN (Cable News Network), em Atlanta, por volta de 1980 que levava aos seus telespectadores vinte e quatro horas de notícias.

Esse movimento possibilitou a segmentação de público trazendo à tona novidades para o segmento e o entusiasmo pela abertura de novos canais e variedades. Com um faturamento estimado na casa dos bilhões nos Estados Unidos e no mundo, a TV paga vem se modificando, diversificando e ganhando maior complexidade com o surgimento de novas tecnologias e modos de interatividade entre o consumidor e o serviço, motivando a entrada no segmento de gigantes das telecomunicações, bancos e mesmo grandes corporações pertencentes a outros ramos da economia.

Na Europa, a penetração da TV paga ainda é tímida, se vislumbrada a sua potencialidade como mercado consumidor dessa tecno- 
logia. No Velho Continente, o modelo de TV Estatal pública é tido como marco televisivo, embora existam países onde a sua difusão seja mais ampla, como os escandinavos (Ramos; Martins, 1995, p.145). A British Broadcasting Corporation (BBC) é um exemplo de emissora pública operando no segmento de rádio e televisão na Grã Bretanha e com prestígio internacional, France 2 na França, TVE (Televión Española), RAI (Radiotelevisione Italiana) entre outras.

Já no Brasil, a história da televisão por assinatura é recente. Os militares haviam tentado implantar e aprovar regulamentação para o setor das telecomunicações, no que tange especialmente ao segmento de televisão por assinatura. Mas, foi por meio da "[...] portaria n. 143, o presidente José Sarney institui o 'Serviço da Recepção de Sinais de TV Via Satélite e sua Distribuição por meios Físicos a Usuários"” (Carvalho, 2000, p.81) e pela Portaria número 250 o "Serviço de Distribuição de Sinais de TV por Meios Físicos DISTV", sob a assinatura do Ministro das Comunicações Antônio Carlos Magalhães.

Com isso, analisando a legislação ${ }^{1}$ do segmento, observou-se que foi no governo José Sarney que se começou a colocar em prática certa regulação no setor, por meio do Decreto n. 95.744 de 23 de fevereiro de 1988, o que se designou de disciplinamento do "Serviço Especial de Televisão por Assinatura".

Além disso, estava colocado de certa maneira o direcionamento de que o serviço seria codificado e, para se ter acesso a ele, era necessário o seu respectivo pagamento. No artigo segundo do Decreto n. 95.744 sublinhava-se que:

O Serviço Especial de Televisão por Assinatura (TVA) é o serviço de telecomunicações, destinado a distribuir sons e imagens a assinantes, por sinais codificados, mediante a utilização de canais

1 Referenciado em: < www2.camara.leg.br/legin/fed/decret/1988/decreto95744-23-fevereiro-1988-445920-publicacaooriginal-1-pe.html>. Acesso em 21 set. 2015. 
do espectro radioelétrico, permitida, a critério do poder concedente, a utilização parcial sem codificação. (Brasil, 1988)².

Mais adiante, no governo Fernando Collor de Mello ocorreram alterações substanciais na forma de gerir as telecomunicações e se colocou fim ao Ministério das Comunicações, fundindo-o a outras pastas com a criação do Ministério da Infraestrutura. Nesse contexto, incorporou-se ao ideário da secretaria a política de audiência pública com vistas à consulta da população para elaboração de determinados serviços, sendo igualmente distribuídas diversas autorizações para a prestação de serviços - DISTV.

Entretanto, foi por meio da Lei n. 8.977 de 1995, no governo Fernando Henrique Cardoso, que a TV a Cabo passou a ter um estatuto mais definido e em seu artigo $5^{\circ}$, I, descrevia, por exemplo, que: "o ato de outorga através do qual o poder executivo confere a uma pessoa jurídica de direito privado o direito de executar e explorar o Serviço de TV a Cabo" (Brasil, 1995), ${ }^{4}$ sendo, portanto, a pessoa jurídica, por sua vez, designada de operadora e a programadora responsável pela produção e distribuição de material televisivo.

Nesse cenário, as empresas operadoras são obrigadas a disporem de canais básicos que são oferecidos sem nenhum custo ao assinante e constituídos, em geral, por redes de televisão aberta e também por canais estatais do executivo, legislativo, judiciário etc. Nesse quadro, Ramos e Martins (1995, p.165) escreveram que:

As principais empresas de TV a Cabo no Brasil, eram, em 1995, a Net Brasil (controlador: Globocabo, do Grupo Roberto Marinho, em associação com os Grupos RBS, da família Sirotsky, e Plimp-

2 Disponível em: <www.ancine.gov.br/sites/default/files/outras-legislacoes-de-interesse/Regulamento_Dec_95744_988_TVA.pdf>. Acesso em: 21 set. 2015.

3 Referenciado em: <wikicom.mc.gov.br/index.php/Minist\%C3\%A9rio_das_ Comunica\%C3\%A7\%C3\%B5es>. Acesso em: 21 set. 2015.

4 Disponível em: <www.planalto.gov.br/ccivil_03/leis/18977.htm>. Acesso em: 21 set. 2015. Essa lei foi revogada pela Lei n. 12.485, de 12 de setembro de 2011. 
son, do empresário Antônio Dias Leite); a Multicanal (controladores: Antônio Dias Leite Neto e Companhia de Mineração do Amapá, em associação com a Globocabo) e a RBS (controlador: Grupo Sirotsky, por meio da Cabo Parbs, da DR Globo e da DR Multicanal, sub-holdings das quais participam respectivamente a Net Brasil, a Globocabo e a Multicanal). A principal empresa de MMDS é a TVA (controlador: Grupo Abril, associado ao Chase Manhattan Bank).

Consequentemente, o que demarcava o cenário da TV paga no Brasil era a presença hegemônica de capital nacional entre os líderes do mercado, com exceção do grupo Abril, que já possuía associação com a iniciativa internacional no segmento; algo completamente diferente do que ocorreu posteriormente e que vige atualmente com a ação pesada do capital estrangeiro em diversas operadoras, acompanhada da redução do capital nacional.

Ademais, de acordo com Carvalho (2000, p.53), foi por volta de 1995 que o Grupo Abril partiu para o mercado de TV paga, sob a marca TVA, por meio da exploração de satélite B1, na banda C. Por conseguinte:

No mercado de banda Ku, a TVA inicia suas operações em 1996, com o lançamento do satélite Galaxy III-R. O Projeto Galaxy Brasil tem 75\% de participação da TVA e 25\% dos demais sócios Hughes Communications, dos EUA; o grupo Cineros, da Venezula e a Multivision, no México. (Carvalho, 2000, p.53).

Além disso, o grupo NetSat associou-se à News Corporation (holding do empresário das comunicações no mundo Rupert Murdoch), à TCI dos EUA e à Televisa do México para criar a marca Sky no Brasil (Carvalho, 2000, p.56).

Já hoje, como assinalado anteriormente, essa composição dos maiores grupos não se estabelece mais entre tais sócios, havendo diferenciações entre os principais investidores desse segmento que se relacionam, em geral, a internacional players das telecomunicações, 
a exemplo da Telmex/América Móvil do México sob as marcas Net, Embratel/Claro TV e a Telefónica da Espanha, dona da Vivo TV no Brasil. Desse modo, observa-se a forte relação desse mercado no momento com investimentos globais de grandes corporações que se somam no uso corporativo do território brasileiro e dirigindo diferentes estratégias.

No mundo, dentre as empresas ${ }^{5}$ que dominam o mercado da produção e difusão da informação no segmento televisivo podem-se destacar corporações como: News Corp, Time Warner, Viacom, Disney, NBC Universal e Sony. Além dessas, há empresas que mantém relações com países de economia central a exemplo do The New York Times, CBS e Person e outras que estão localizadas em área de expansão das telecomunicações, a exemplo da América Latina com grupos como Globo, Clarín, América Móvil, Televisa e Cisneros. Apesar de se concentrarem, por ora das vezes, em mercados distintos, essas empresas desenvolvem também parcerias em seus mercados locais de atuação, agregando conteúdos em suas grades de grupos variados.

Segundo Torres (2005, p.47), o Grupo Time Warner, por exemplo, com sede nos Estados Unidos, tem operações no segmento de televisão por assinatura com canais de exibição de filmes especialmente como HBO e TNT, CNN (canal dedicado à notícias), Cartoon Network e Boomerang, voltados ao público infantil e adolescente. Além disso, a Time opera no mercado de internet com o provedor America Online (AOL), no segmento de cinema com a Warner Bros, no mercado da música com a Warner Music e editorial com a publicação de mais de uma centena de títulos, entre outras atividades.

A NBC, por sua vez, para Torres (2005, p.48), é resultado da fusão entre General Electric e Vivendi Universal. A companhia se destaca, sobretudo, na televisão aberta dos Estados Unidos, mas

5 Esse parágrafo foi construído tendo como referência a contribuição de Torres (2005, p.41 e 42) quando escreveu sobre o monopólio e concentração do mercado de telecomunicação, baseando-se em Martín Becerra (2003). 
mantendo, também, outros negócios no mundo no segmento televisivo fechado com destaque para canais pagos como: CNBC World voltado à veiculação de notícias, Sci Fi (ficção), entre outros.

Já de Hupert Murdoch, ${ }^{6}$ da Austrália, vem a News Corporation e que, por seu turno, se constitui em uma das empresas com atuação global mais poderosas do mundo, dedicando-se tanto à produção de conteúdo quanto ao controle dos meios de transmissão com várias operadoras de televisão por assinatura no mundo como a Sky, DirecTV, Foxtel, entre outras, e também controladora de diversos canais pagos, a exemplo da Fox (entretenimento), Fox News (notícias), Fox Sports (esportes), FX (público masculino), National Geographic (documentários) etc. e, também, no mercado editorial (The Times, The Sun, Daily Telegraph, New York Post).

Já no que tange ao Brasil observa-se um grande relacionamento das Organizações Globo com o capital estrangeiro no mercado de TV paga, seja por meio da operação da TV, a cabo Net, ou pela ação da TV por satélite Sky, que inclusive incorporou num passado não muito distante outro grupo importante no país: a DirecTV, que tinha como um de seus principais acionistas o grupo Abril em associação com capital internacional.

O grupo Globo, por sua vez, constitui-se atualmente na principal empresa de comunicação do Brasil, estando também entre os maiores do mundo, destacando-se especialmente por meio da Rede Globo de Televisão. Publica jornais como O Globo, além de possuir participação no maior jornal de economia do país: Valor Econômico, em parceria com a Folha de S.Paulo; no mercado de rádio como Globo FM e CBN; e, por fim, uma ampla gama de publicações no mercado editorial e gráfico de revistas como a Época, livros e outros.

A história desse grupo encontra na Rede Globo de Televisão destaque nacional como a empresa líder em audiência e internacionalmente, com a venda de diversas produções do canal que foram exibidas, em vários países. Assim, Munhoz (2008), no âmbito da

6 Parágrafo baseado em Torres (2005, p.50). 
Geografia, traduziu o crescimento dessa companhia ao descrever a inserção desse veículo no território brasileiro, considerando que:

Para que esta empresa se estabelecesse no território brasileiro como uma rede de televisão nacional, adotou-se o modelo criado pela rede de televisão estadunidense National Broadcasting Company (NBC), firmando contrato com emissoras locais já existentes e com emissoras criadas para ser afiliadas da Rede Globo de Televisão [...]. (Munhoz, 2008, p.17)

Deste modo, a rede pôde ganhar maior influência e difusão, utilizando nacionalmente o território. Atualmente, segundo informações disponibilizadas pelo sítio Donos da Mídia, em 2013, a Rede Globo era a:

Maior rede de televisão em operação no Brasil, a Rede Globo encabeça o Sistema Central de Mídia nacional por vários motivos. Entre eles, sua contínua relação com empresas regionais de comunicação desde 1965. São 35 grupos que controlam, ao todo, 340 veículos. E sua influência é forte não apenas sobre o setor de TV. A relação com empresas em todos os estados permite que o conteúdo gerado pelos 69 veículos próprios do grupo carioca seja distribuído por um sistema que inclui outros 33 jornais, 52 rádios AM, 76 FMs, 11 OCs, 105 emissoras de TV, 27 revistas, 17 canais e 9 operadoras de TV paga. Além disso, a penetração de sua rede de televisão é reforçada por um sistema de retransmissão que inclui 3305 RTVs. $^{7}$

Ademais, as Organizações Globo sustentam envolvimento no segmento fonográfico, fílmico e de vídeo, de internet com provedor e conteúdo, bem como ampla operação no mercado de TV por as-

7 Disponível em: <http://donosdamidia.com.br/rede/4023>. Acesso em: 21 set. 2015. 
sinatura por meio da ação da Globosat e participação acionária nas operadoras NET e Sky. A partir da ação da Globosat são veiculados:

[... 33 canais (20 canais lineares +3 exclusivos em HD + 9 canais pay-per-view +1 canal internacional) e 3 serviços de conteúdo sob demanda, que formam o melhor e mais variado conteúdo da TV atual e que estão entre os mais assistidos pelos assinantes. Uma programação que faz da Globosat a maior programadora de TV por assinatura da América Latina e a líder de mercado no Brasil. ${ }^{8}$

Nesse universo, podem ser mencionados canais como Viva, dedicado à exibição de programas variados de entretenimento, seriados produzidos e transmitidos pela Rede Globo de Televisão, os canais Sportv 1, Sportv 2, Sportv 3 de esportes, a Globo News, dedicada à apresentação de notícias e jornalismo, GNT (canal de variedades), Multishow (música e entretenimento), Universal Channel (ligado ao grupo norte-americano NBC), Combate (canal de lutas), Megapix (filmes dublados), Canal Brasil (filmes e documentários nacionais), rede Telecine (variada gama de canais de filmes), Off (canal relacionado a aventuras e à natureza), Gloob (canal infantil), entre outros.

Já o grupo Abril é outra grande empresa importante do segmento no Brasil. Observa-se ampla participação no mercado editorial com diversas publicações de revistas como a Veja, Escola, Superinteressante, entre outras. Além disso, o grupo detém participação no setor de editoras de livros didáticos como é de se citar Ática e Scipione. No quesito internet, dispõe de um amplo portal de dados e de publicações, além de ter participado da construção do Universo Online (UOL).

Para Torres (2005, p.53):

8 Disponível em: <http://canaisglobosat.globo.com/index.php/canais>. Acesso em: 21 set. 2015. 
No ramo de TV por assinatura a Abril foi pioneira, com o lançamento da TVA, a primeira operação de televisão por assinatura do país (1991) e a MTV Brasil, primeiro canal de TV segmentada do Brasil (1990). Opera em sistema de cabo em Curitiba, Florianópolis, Camboriú, Foz do Iguaçu e São Paulo; e MMDS em São Paulo, Rio de Janeiro, Niterói e Curitiba. O acesso à Internet banda-larga é oferecido pelo Ajato vinculado ao serviço de TV por assinatura. Em 2004 passou a oferecer o serviço TVA digital e o VoIP, serviço telefônico através do Protocolo de Internet (IP), em conjunto com a empresa Primeira Escolha. A Abril opera com parceiros internacionais na TVA como grupo Falcon e o banco JP Morgan e têm parceria no canal MTV com a Viacom.

A Abril também foi pioneira no Brasil no processo de associação com o capital internacional no mercado de TV paga. Hoje a TVA, que passou a ser Telefônica Digital, opera com a marca Vivo TV e está disponível em diversas praças do território nacional, consolidando-se como uma das principais marcas do segmento, como será destacado adiante.

Logo, observa-se que a TV por assinatura se insere no contexto da globalização capitalista com a livre ação de corporações internacionais, em um mercado segmentado e voltado para as classes de maior poder aquisitivo, embora haja uma sensível penetração na classe média e mesmo em comunidades carentes. Sua afirmação e expansão, portanto, se vincula plenamente ao avanço das telecomunicações e da sociedade informacional. Nesse sentido destaca-se que: "Today it is the television which has the most dramatic impact on people's awareness and perception of worlds beyond their own direct experience [...]" (Dicken, 1998, p.158).

Com isso, são eleitas estratégias de consumo com determinadas tipologias e nichos de mercado, nos quais as empresas inserem forte investimento e concentram estratégias de marketing e espaciais do ponto de vista do ganho produtivo e de capital e por conseguinte: 
Os grandes conglomerados encontraram na TV por assinatura um veículo que articula o potencial sinérgico de seus produtos. Grande parte do acervo das empresas que compõem os megagrupos - filmes, séries para TV, desenhos animados, arquivo de transmissões esportivas, documentários, reportagens e uma grande quantidade de produtos - produzida nas últimas décadas é reempacotada e apresentada inúmeras vezes nos canais de TV por assinatura espalhados em todos os continentes. São somadas a esse acervo a produção atual e as transmissões esportivas e de shows e espetáculos. O reaproveitamento é feito em detrimento da produção regional, restringindo a pluralidade cultural, a produção e o espaço de expressão da cultura nacional. (Torres, 2005, p.59)

Grandes corporações globais das comunicações, desse modo, atuam em diferentes mercados de forma instantânea e simultânea, levando consigo uma visão de mundo, associada, em geral, ao dinheiro e ao consumo. Estas, por sua vez, mantêm acordos de cooperação e de ação com empresas que atuam regionalmente e localmente, fortalecendo suas estratégias de penetração espacial e ampliando seus lucros, quer seja pela difusão de diferentes canais, quer seja pela possibilidade de operarem em distintas prestadoras de serviços, na forma de "redes-suporte", que dão consequentemente o apoio aos serviços ofertados pelas companhias.

Mesmo que as corporações operem na forma direct to home, ou seja, via satélite por meio de ondas, a questão das redes comparecerá, da qual o satélite é, portanto, um nó, sem sombra de dúvidas, do processo de comunicação e os pontos receptores instalados nas casas dos clientes e estabelecimentos comerciais são os pontos finais dessa dinâmica; diferentemente da televisão a cabo, apoiada, por exemplo, no uso de cabo coaxial ou mesmo fibra óptica, em que a circulação da informação ocorre por meio de aparato material de suporte prévio às residências com a transmissão inicial feita à programadora, para depois chegar até as residências das pessoas.

Conforma-se, nesse quadro, uma nova hierarquia na qual haveria um centro de recepção dos sinais do satélite em via terrestre para 
depois ser distribuído às residências e não de forma direta, como ocorre no sistema DTH. Ademais, é importante frisar que:

Através das redes, podemos reconhecer, grosso modo, três tipos ou níveis de solidariedade, cujo reverso são outros tanto níveis de contradições. Esses níveis são o nível mundial, o nível dos territórios dos Estados e o nível local. (Santos, 2008, p.270).

Com isso, localmente, as companhias agem no sentido de difundir gostos e aspectos culturais que são exógenos às comunidades atendidas, em diferentes países e contextos. Estas acabam fazendo, muitas vezes, somente uma "tradução" do idioma original para o modo "legenda" na versão da língua do país receptor, uma "dublagem” ou mesmo só retransmitindo o sinal sem adaptações linguísticas. Porém, é preciso destacar que:

[... ] linguagem das normas e ordens que atores longínquos fazem repercutir instantaneamente e imperativamente sobre os outros lugares distantes. Tais redes são os mais eficazes transmissores do processo de globalização a que assistimos. (Santos, 2008, p.266)

Por sua vez, como potentes motores da globalização, as telecomunicações formam um pilar para sustentar o ideal do liberalismo ao se reproduzirem em diferentes territórios, ampliando, portanto, seu poder de ação e divulgando os ideais do livre mercado e ação do capital, por meio dos principais grupos de mídia hegemônicos. Pode-se, consequentemente, argumentar que o processo de homogeneização de costumes e tradições não só ocorre nas ruas, mas também tem seu ponto de poder associado às residências das pessoas com a penetração cada vez mais acelerada de bens como a televisão paga, que só tem crescido nos últimos anos no Brasil.

Para se ter ideia desse quadro basta afirmar que para o final de 2011, conforme a Associação Brasileira de Telecomunicações (Te- 
lebrasil), eram 12,7 milhões de assinantes de TV por assinatura e até setembro de 2012 15,4 milhões, com densidade de 7,8 conforme o Quadro 6. Interessante é, também, comentar a evolução do segmento ao longo do tempo que em 1993 não atingia 1 milhão de assinantes e em 2011 já alcançava a cifra de 15,4 milhões de assinantes.

Quadro 6-Densidade e quantidade dos assinantes de TV paga no Brasil.

\begin{tabular}{|c|c|c|}
\hline Período & Densidade & Assinantes de TV por assinatura em milhões \\
\hline 1993 & 0,2 & 0,3 \\
\hline 1994 & 0,3 & 0,4 \\
\hline 1995 & 0,6 & 1 \\
\hline 1996 & 1,1 & 1,8 \\
\hline 1997 & 1,5 & 2,5 \\
\hline 1998 & 1,5 & 2,6 \\
\hline 1999 & 1,6 & 2,8 \\
\hline 2000 & 2 & 3,4 \\
\hline 2001 & 2,1 & 3,6 \\
\hline 2002 & 2 & 3,6 \\
\hline 2003 & 2 & 3,6 \\
\hline 2004 & 2,1 & 3,9 \\
\hline 2005 & 2,3 & 4,2 \\
\hline 2006 & 2,5 & 4,6 \\
\hline 2007 & 2,8 & 5,3 \\
\hline 2008 & 3,3 & 6,3 \\
\hline 2009 & 3,9 & 7,5 \\
\hline 2010 & 5 & 9,8 \\
\hline 2011 & 6,5 & 12,7 \\
\hline $2012 *$ & 7,8 & 15,4 \\
\hline
\end{tabular}

Fonte: Telebrasil (Associação Brasileira de Telecomunicações) em parceria com a Teleco com base na ABTA e Anatel. Reformatado por Jurado da Silva (2013).

Notas: A densidade foi calculada utilizando a estimativa do IBGE para a população em dezembro do ano. O IBGE publicou em agosto de 2008 uma nova estimativa da população brasileira para julho de 2008 com uma redução de 2,2 milhões em relação à estimativa anterior.

* Referente ao período de janeiro a setembro de 2012. 
Ademais, analisando-se o documento "O Desempenho do Setor de Telecomunicações no Brasil Séries Temporais”, produzido pela Telebrasil (2012, p.125), observa-se que a tecnologia Direct to home, em referência a 2011, possuía 54,8\% do total de assinantes de TV paga, seguida pela TV a cabo com 43,3\% e MMDS 1,9\%. Por tecnologia, temporalmente, a TV a cabo foi a que perdeu maior percentual de assinantes em relação às demais tecnologias e a Direct to home a que mais se expandiu. Desse universo, em 2011, a tecnologia MMDS contava 28 prestadoras de serviço, TV a cabo 90 e a DTH 14.

Dados mais recentes da Associação Brasileira de TV por Assinatura (ABTA $)^{9}$ demonstram que eram 17.622.166 assinantes no terceiro trimestre de 2013, com faturamento total (incluindo publicidade) de 7.134.007.177 reais para o mesmo período e 95.365 empregos diretos e indiretos. Agora, tendo como base o documento "Panorama dos serviços de TV por assinatura" em sua 49a edição, publicado em junho de 2011 (p.13) pela Anatel, o Estado de São Paulo possuía 39,9\% dos assinantes, seguido pelo Rio de Janeiro com 14,3\%, Minas Gerais 8,2\%, Rio Grande do Sul 6,4\% e os demais estados $31,2 \%$.

Nesse cenário de dados, ainda vale ressaltar que:

Considerando-se as recentes deliberações do Conselho Diretor da Anatel, onde foi concedida anuência para incorporação da NET pela Embratel e da Abril pela Telefônica [...] Em junho de 2012 o grupo econômico NET/Embratel atingiu o índice de 53,83\% de participação no mercado de TV por Assinatura, equivalendo a 7.824.438 assinaturas, seguido do grupo Sky/Directv com 30,79\%, compreendendo 4.475.837 assinaturas, e dos demais grupos com $15,38 \%$, totalizando 2.234 .908 assinaturas. ${ }^{10}$

9 Disponível em: < www.abta.org.br/dados_do_setor.asp>. Acesso em: 21 set. 2015.

10 Disponível em: http://www.anatel.gov.br/Portal/verificaDocumentos/ documento.asp? numeroPublicacao $=278907 \&$ pub $=$ original $\&$ filtro $=1 \&$ docu 
Tendo em vista esse contexto, o Mapa 4 ilustra a distribuição dos assinantes da TV paga no Brasil. Nele, é possível visualizar que a tecnologia por satélite (DTH) é maioria em quase todos os estados no Brasil. Só São Paulo apresentava uma composição diferenciada dos demais tanto em número de assinantes para dezembro de 2012 (6.229.076 assinantes) quanto no grau de concorrência por tecnologia, com a maior presença de TV a cabo (TVC) no país.

O Acre, por sua vez, foi o estado com menor número de assinantes (25.031 assinantes). Assim, tecnologias como MMDS e TVA nem sequer podiam ser percebidas visualmente em termos de distribuição territorial nessa rede de suporte à tecnologia da TV paga.

Já quando se trata da análise das operadoras e programadoras no território brasileiro é possível evidenciar a concentração do segmento no Estado de São Paulo com destaque para a região metropolitana de São Paulo, Belo Horizonte e Rio de Janeiro no Sudeste; Curitiba, Florianópolis e Porto Alegre no Sul; Brasília no Centro-Oeste; no Nordeste a importância de capitais como Aracaju e Salvador, seguidas por outros pontos e capitais na faixa litorânea; e, por fim, no restante do Brasil uma topologia de pontos dispersos sendo quase que invariavelmente seguidos por capitais interioranas, a exemplo de Manaus.

Por isso, é tendo como base tal quadro de disparidades socioespaciais e da técnica que serão trabalhados nos próximos subcapítulos a análise das principais operadoras de televisão por assinatura no Brasil, na modalidade a cabo e especialmente por satélite. 

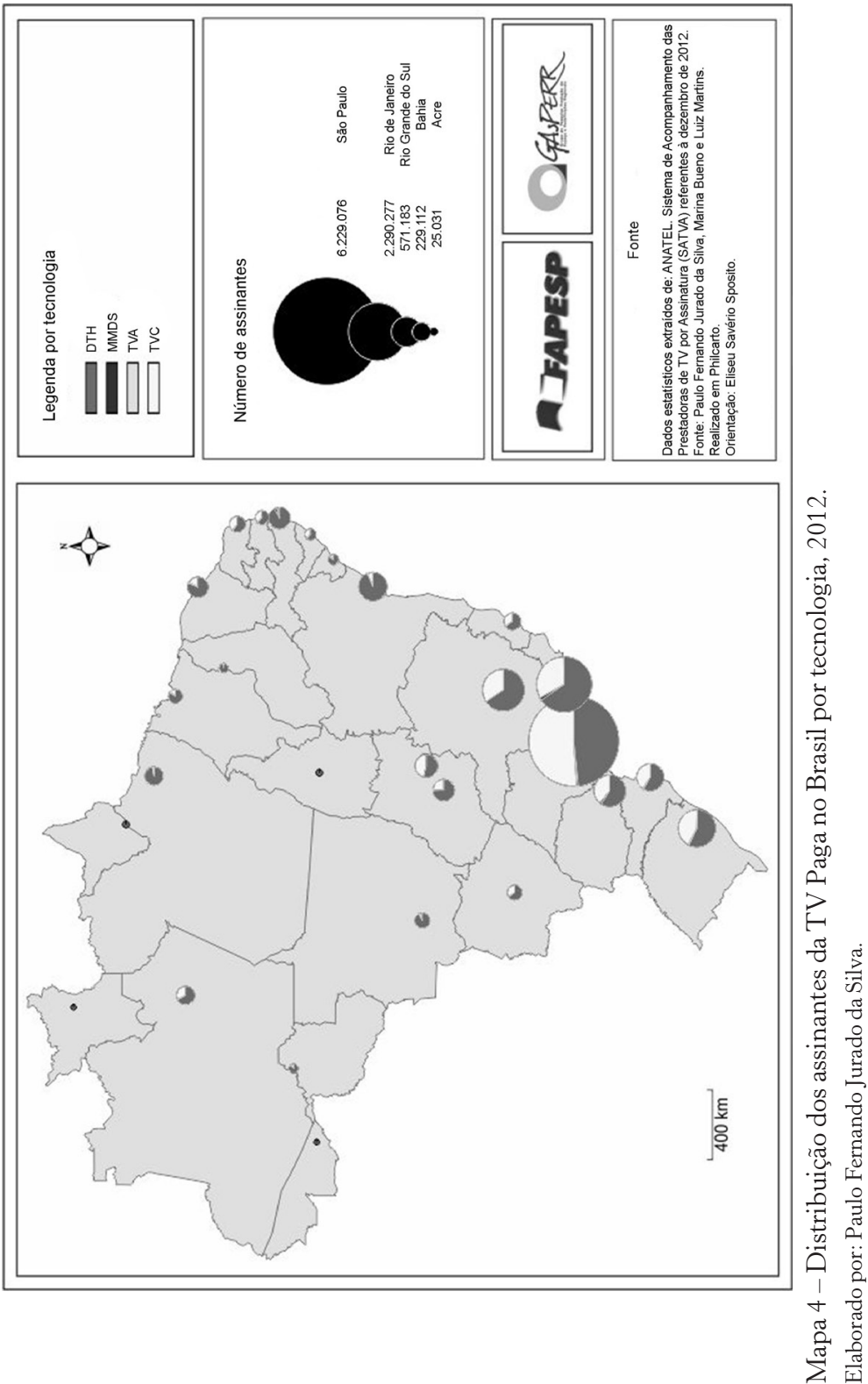


\section{NET}

A NET iniciou suas atividades no segmento de TV a cabo no Brasil em 1991, sob a marca Multicanal ${ }^{11}$, de propriedade do empresário do ramo da mineração Antonio Dias Leite Neto. Paulatinamente, a empresa foi adquirindo licenças e algumas operadoras locais, ampliando sua ação em diferentes áreas e se tornando uma das maiores companhias do segmento no Brasil.

Entre 1992 e 1993, a Globopar e a Ralph Partners II' ${ }^{12}$ entraram para o negócio como sócias da empresa. Com o passar do tempo, vão sendo incorporadas outras empresas como a Net BH, Globo Cabo Participações S.A., Net Sul, entre outras. No sítio eletrônico da Net, por exemplo, na parte que toca ao perfil corporativo e histórico foi destacado de forma ilustrativa que:

Sob nosso nome anterior, Multicanal Participações S.A. (Multicanal), registramos nossas ADSs pela primeira vez no NASDAQ Global Market em outubro de 1996. No final de 1997, os principais acionistas venderam suas participações para o Grupo Globo. Em setembro de 1998, a Multicanal adquiriu determinados ativos de cabo e os respectivos passivos do Grupo Globo e mudou seu nome para Globo Cabo S.A. Os ativos que adquirimos do Grupo Globo incluíam uma participação de 50,0\% na Unicabo Participações e Comunicações S.A. (Unicabo) e participação controladora em três importantes operadoras de cabo em áreas metropolitanas: a Net São Paulo Ltda. (Net São Paulo), a Net Rio Ltda. (Net Rio) e a Net Bra-

11 Possebon relatou que "Uma história que corria em paralelo à disputa entre dois maiores grupos de mídia do país, mas que teria papel central na consolidação do mercado de TV paga no Brasil, é a da Multicanal. A empresa foi criada por Antônio Dias Leite Neto [...]" (2009, p.57). Os dois maiores grupos que o autor se referia era a Abril e Globo, sendo que este último, por sua vez, conseguiu avançar nas negociações e participar do quadro societário da empresa posteriormente.

12 Informação referenciada em: <www.netcombo.com.br/netPortalWEB/ appmanager/portal/desktop?_nfpb=true\&_pageLabel=institucional_sobre_ net_historia_paginacao_book_1_page>. Acesso em: 21 set. 2015. 
sília Ltda. (Net Brasília). Em maio de 2000, adquirimos os 50,0\% restantes da Unicabo. Em setembro de 2000, concluímos a aquisição da Net Sul Holding S.A., a então proprietária de 99,99\% da Net Sul Comunicações Ltda. (Net Sul), à época a segunda maior operadora de televisão a cabo no Brasil. A aquisição da Net Sul aumentou significativamente a nossa base de assinantes e nos proporcionou acesso aos mercados do sul do Brasil, uma região que historicamente nós não atendíamos. Em maio de 2002, mudamos nosso nome de Globo Cabo S.A. para Net Serviços de Comunicação S.A. ${ }^{13}$

Outro fato relevante ocorreu em 2005, quando a Telmex ingressou na estrutura societária e, portanto: "A Telmex adquire 49\% de participação na Globo Participações, sociedade que conta com a participação de $51 \%$ das Organizações Globo [...]". ${ }^{14}$

Foi em 2012, porém, que essa estrutura de comando das Organizações Globo se alterou, substancialmente, uma vez que a América Móvil passava a ser a controladora da Net, ingressando nessa empreitada por meio da Empresa Brasileira de Telecomunicações S.A. ${ }^{15}$ Embratel Participações S.A. e GB Empreendimentos e Participações S.A. (parceria com a Globo).

Nesse cenário, o grupo América Móvil (ligado a Telmex no México) vai ampliando sua participação no continente, sendo:

[...] uma empresa com atuação no setor de telecomunicações com ampla penetração na América Latina (México, Argentina, Brasil, Colômbia, Chile, Peru) e Estados Unidos. Opera com rede 100\% digital e possui rede de fibra óptica de 74 mil quilômetros com conexões via cabo submarino com 39 países. Oferece serviços de telecomunicações como transmissão de voz, dados e vídeo e acesso à

13 Disponível em: <www.netcombo.com.br/static/ri/>. Acesso em: 21 set. 2015.

14 Extraído da Net. Disponível em: <www.netcombo.com.br/netPortalWEB/ appmanager/portal/desktop?_nfpb=true\&_pageLabel=institucional_sobre_ net_historia_paginacao_book_2_page>. Acesso em: 21 set. 2015.

15 Para maiores detalhes sobre o assunto consultar a página: <www.estadao. com.br/noticias/geral,america-movil-recebe-aval-da-anatel-para-controlar-a-net,828367,0.htm>. Acesso em: 21 set. 2013. 
Internet. É líder em telecomunicações no México, com mais de 15 milhões de linhas em operação, alcançando $89 \%$ dos habitantes, além de mais de 165 mil usuários de Internet [...]. (Torres, 2005, p.51)

Além disso, o grupo Globo se tornou um grande aliado da companhia no momento e, também, continua a ser um dos sócios. Destarte, as Organizações Globo têm se mantido focada na tarefa de ofertar diversos canais à operadora, bem como investindo em produção de conteúdo nacional.

Em 2012, o lucro da Net Serviços segundo a Exame.com foi de 7,94 bilhões, e: "O crescimento na base de domicílios com TV por assinatura da Net foi um pouco menor, mas também significativo: alta de 13,8\% em relação ao ano anterior, encerrando 2012 com 5,381 milhões de clientes de TV paga". ${ }^{16}$

Com isso, a empresa tem ofertado ainda banda larga, TV por assinatura e telefone na forma de combos e pacotes integrados, ampliando sua gama de clientes e serviços, com a entrada em novos mercados consumidores e crescimento da sua base de clientes em áreas já exploradas.

Atualmente, a companhia está presente em mais de 100 cidades do país, consolidando-se como a maior na área de multisserviços da América Latina. No Brasil, opera principalmente nos grandes centros consumidores a exemplo de capitais como Brasília, São Paulo, Belo Horizonte, Porto Alegre e Rio de Janeiro, mas também em cidades intermediárias como Marília, Bauru, Maringá, Chapecó, entre outras.

\section{Claro TV}

A Claro TV (antiga Via Embratel) é outra companhia vinculada à América Móvil no Brasil, sendo uma operadora baseada no sistema Direct to Home. No momento, o acesso a sua programação

16 Extraído de: <http://exame.abril.com.br/negocios/noticias/net-servicosfatura-r-7-94-bilhoes-em-2012-alta-de-18-6>. Acesso em: 21 set. 2015. 
é feito por uma antena parabólica pequena e por um receptor com cartão de acesso específico.

A Embratel é fruto do processo de desestatização no Brasil, alternando diferentes comandos acionários na sua história. No leilão do sistema Telebrás, a companhia foi vendida à MCI, que depois vendeu sua participação ao grupo de Carlos Slim, no México. Dessa maneira, é válido ressaltar que:

[...] No Brasil, a Telmex controla a Embratel, maior empresa de telefonia a distância do país. A Embratel também está presente na telefonia fixa local, presta serviço de interconexão à Internet, incluindo provedores. Possui subsidiárias estratégicas, como a Star One, maior sistema de satélites da América do Sul, com sua frota Brasilsat A2, B1, B2, B3 e B4. Oferece serviços de Internet em banda larga, via satélite, para clientes residenciais e corporativos. Outras subsidiárias importantes têm serviço de telecomunicações interligando países como Argentina, Chile e Uruguai com o Brasil. Na Internet é responsável pelo portal Click 21. (Torres, 2005, p.51)

E, nessa perspectiva, é útil frisar ainda que:

A Embratel é uma empresa do Grupo América Móvil. A Telmex adquiriu a Embratel em julho de 2004 da MCI. Em 2007 a Embratel passou a fazer parte da Telmex Internacional, que foi incorporada pela América Móvil em 2010.

A Embratel têm a concessão para Longa distância nacional e internacional em todo o país, correspondente ao setor 35, Região IV, do PGO (Código de operadora: 21). ${ }^{17}$

Logo, foi no ano de 2011 que a empresa, no segmento de televisão por assinatura, passou a ser designada de Claro TV. Além disso, a Claro tem possibilitado ofertar aos seus clientes serviços no

17 (Disponível em: <http://www.teleco.com.br/operadoras/embratel.asp.> Acesso em: 21 set. 2015) 
padrão triple play, ou seja, TV por assinatura, internet e telefonia celular, sob uma única marca com preços competitivos.

A Claro, por sua vez, é a maior empresa de telefonia celular da América Latina com atuação em diversos países, a exemplo de Argentina, Brasil, México, Colômbia e outros. No momento, a companhia está presente em todo território nacional, oferecendo seus serviços a mais de cinco mil municípios brasileiros com mais de duzentos canais nas modalidades digital e high definition, além de músicas e rádio.

Finalmente, a Claro TV, segundo Relatório da Administração Embratel Participações S.A., tinha fechado o ano de 2012 com 3.118 .000 de clientes, o que correspondia a um crescimento de $37 \%$ em relação ao ano de $2011^{18}$, fortalecendo-se no mercado de TV paga e se somando à Net como um grande player da América Móvil no Brasil para fazer frente à concorrência.

\section{Sky Brasil}

A Sky Brasil foi implantada no país em 1996, sendo uma operadora de televisão por assinatura na modalidade por satélite, por meio do sistema Direct to home (DTH) e a maior operadora nessa modalidade no território nacional, tendo como acionistas principais, no momento, o DirecTV Group e a Globo Comunicação e Participações S.A.

O DirecTV Group está entre os maiores grupos do segmento no mundo com operações nos Estados Unidos e América Latina. No Brasil, a Sky foi resultado da fusão com a DirecTV. A DirecTV, por sua vez, possibilitou ainda mais a concentração de assinantes nas mãos dessa última, fortalecendo-a como líder no segmento DTH, uma vez que a DirecTV gozava de uma ampla base de assinantes e tinha sido

18 Parágrafo referenciado na página 14 do Relatório da Administração Embratel Participações S.A.: Disponível em: <http://www.embratel.com.br/Embratel02/files/dc/08/07/DF\%20EBPAR\%202012\%20-\%2020-03-2013.pdf>. Acesso em 10 jul. 2013. 
a marca pioneira direct to home, tendo como um de seus acionistas o Grupo Abril (no passado) em parceria com o capital internacional.

Tal fato ocorreu porque o DirecTV Group resolveu unificar suas operações no Brasil quando tinha como controladora a News Corporation do empresário Rupert Murdoch, que decidiu fortalecer a marca Sky, como ocorreu no México. O ato, conforme Torres (2005, p.109), se deu em 11 de outubro de 2004 pela Globo e News Corporation, fazendo parte de uma estratégia espacial da News em dar maior visibilidade às marcas líderes em cada mercado regional.

A News, por sua vez, opera em vários mercados de televisão por assinatura no mundo, com destaque para Europa, Austrália e também América Latina. No quesito nacional, a Globo detém a liderança na produção de conteúdo, e também é parceira estratégica do grupo News para suas ações e estratégias de mercado.

Antes da fusão, segundo o Teleco, os acionistas da Sky Brasil: “[...] eram a Globopar (54\%), News Corporation (36\%) e Liberty Media Corporation (10\%)". ${ }^{19}$ Entretanto, o primeiro passo para o movimento de transformações societárias foi a compra de 34\% da Hughes Eletronics nos Estados Unidos (Torres, 2005, p.109), controladora da DirecTV em diversos países.

Depois disso, o controle da empresa no continente passou para John Malone da Liberty Media. Em 2010, segundo a Revista Exame o empresário "[...] deixou o conselho da DirecTV, que aqui no Brasil controla a Sky, reduzindo sua participação na operadora para apenas 3\%", ${ }^{20}$

No que tange às estratégias da Sky no país, a corporação lançou em 2008, conforme o Teleco (2012), ${ }^{21}$ o satélite Intelsat 11 que possibilitou à empresa ampliar e fortalecer sua gama de canais digitais, bem como em high definition e atualmente:

19 Disponível em: <www.teleco.com.br/operadoras/sky.asp>. Acesso em: 21 set. 2015.

20 Disponível em: <http://exame.abril.com.br/tecnologia/noticias/revista-lista-os-mais-influentes-da-era-da-informacao? $\mathrm{p}=10>$. Acesso em: 21 set. 2015.

21 Disponível em: <www.teleco.com.br/operadoras/sky.asp>. Acesso em: 21 set. 2015. 
A SKY é a maior operadora de TV por assinatura via satélite em alta definição da América Latina, com transmissão para todo o território nacional. Possui mais de 15 milhões de telespectadores em todo Brasil, que representam aproximadamente $30 \%$ de todos os assinantes de TV paga do País. ${ }^{22}$

Nesse cenário, a Sky Brasil tem se consolidado como uma grande empresa no segmento de telecomunicações e inclusive no período recente, ofertando internet banda larga a algumas cidades brasileiras, na tecnologia 4G, possibilitando aos clientes acessar pacotes integrados de banda larga e TV paga. Além disso, a Sky disponibiliza diversos serviços aos seus clientes como vídeo calibragem, pay per view, gravações de programas, entre outros diferenciais.

Segundo o jornal Valor Econômico, ${ }^{23}$ o lucro líquido global da DirecTV, que controla a Sky no Brasil, foi de 2,9 bilhões de dólares no ano de 2012, com receita de 29,7 bilhões de dólares. Para a InfoMoney, ${ }^{24}$ a base de clientes da Sky para maio de 2013 era de 5.212.359.

Por fim, a Sky se coloca como um grande player no mercado brasileiro de televisão por assinatura, disputando o mercado com os grupos América Móvil (Net e Claro TV) e Telefónica por meio da Vivo TV, como será relatado a seguir.

\section{Vivo TV}

A Vivo TV foi no passado a TVA (Televisão Abril), de propriedade do Grupo Abril, que disputou a liderança do segmento com outros grupos, a exemplo da Globo. Tal grupo é um dos maiores

22 (Disponível em: <www.sky.com.br/institucional/Empresa/QuemSomos. aspx>. Acesso em: 21 set. 2015).

23 Disponível em: <www.valor.com.br/empresas/3005302/dona-da-operadora-de-tv-sky-tem-alta-de-31-no-lucro-trimestral>. Acesso em: 21 set. 2015.

24 Disponível em: <www.infomoney.com.br/negocios/grandes-empresas/noticia/2840605/directv-revisa-para-baixo-base-clientes-sky-brasil>. Acesso em: 21 set. 2015 . 
no segmento de mídia no país, controlando diversos veículos de comunicação.

Segundo Carvalho (2000, p.67), a empresa iniciou suas atividades no mercado de TV por assinatura “[...] em 1991, com cinco canais: Showtime, ESPN (transmitidos inicialmente em UHF), TNT, Supercanal e CNN (transmitidos em MMDS)". Ainda para este autor, a TVA tinha como principais acionistas, além do Grupo Abril, empresas de capital estrangeiro como Falcon Cable, Chase Manhattan e Hearst Corp. A parceria e até mesmo a exclusividade com canais estrangeiros fez da TVA uma das maiores empresas da área, como elucidou Torres (2005) quando escreveu que:

Em relação à produção e distribuição de conteúdo, a TVA desenvolveu parcerias com a MTV, HBO Brasil, ESPN Brasil, Eurochannel, conseguindo prioridade e, em alguns casos, exclusividade desses canais em sua grade de programação, o que se tornou um diferencial importante no mercado, ajudando a TVA a manter a liderança do mercado durante alguns anos. (Torres, 2005, p.129)

Por volta de 1996, em parceria com o grupo Cisneros, da Venezuela, e a Hughes Eletronics, lançaram a DirecTV no Brasil, sendo o primeiro serviço de televisão por assinatura via satélite no país, controlando cerca de $75 \%$ desta nova empresa que depois iria se fundir com a Sky (Torres, 2005, p.130).

Ainda segundo esse mesmo autor, a empresa (com o apoio da Bell Canadá International) lançou a Canbras, também em 1996, com sistema de cabos em regiões como ABCD, Vale do Paraíba e Baixada Santista. Nesse contexto de investimento, a TVA partiu para "[...] a aquisição da totalidade ou de percentuais em operações de cabo e MMDS no Paraná e em Santa Catarina, além de Brasília, Goiânia e Belém" (Possebon, 2002, p.154).

A concorrência com o grupo Globo e a crise econômica internacional, segundo a interpretação de Possebon (2002, p.166), fizeram o Grupo Abril negociar parte de suas ações. Foi assim que ocorreu com canais como ESPN, HBO Brasil, Eurochannel, bem como 
com a sua saída do provedor Universo Online (UOL) em parceria com o grupo Folha. Além disso, em 1999 o Grupo retirou suas posições da DirecTV, repassando-as para a Hughes Eletronics e fazendo com que a Abril concentrasse suas atenções na TVA.

A partir de então começou a relacionar melhor o mercado editorial da Abril com essa televisão e também firmando acordos com operadoras de telefonia celular, visando reproduzir e distribuir em aparelhos móveis alguns dos canais veiculados pela TVA. Além disso, o grupo Bell Canadá vendeu parte de suas ações na operadora de TV a cabo para a Horizon, possibilitando o nascimento de uma nova empresa de TV a cabo no país, a Vivax, de acordo com Torres (2005, p.135).

Com o passar do tempo, o grupo Telefónica da Espanha adquiriu o controle da TVA, dando a possibilidade de ofertar serviços triple play (TV paga, internet banda larga e telefonia fixa) aos seus clientes, alterando sua marca de televisão para Telefônica Digital e depois para Vivo TV em 2012, quando a marca Vivo passou a unificar nominalmente a companhia.

No momento, a companhia não opera em todo o território nacional, mas em algumas regiões apenas. No sítio institucional da empresa $^{25}$ comparece que a Vivo TV opera por fibra, cabo digital, cabo analógico, MMDS e por satélite, oferecendo uma ampla variedade de canais, música e rádio.

No ano de 2012, a chamada receita consolidada ${ }^{26}$ do grupo Telefônica Vivo foi de 33,931 bilhões de reais com crescimento de 16,5\% em relação ao ano anterior. No segmento da TV por assinatura, a receita líquida foi de 594 milhões de reais. ${ }^{27}$

25 Informação consultada no sítio da companhia. Disponível em: <www.vivotv. tv.br/Faq/Index>. Acesso em: 21 set. 2015.

26 Os números são referenciados na reportagem "Lucro da Telefônica Vivo cresce 2,2\% em 2012” da Veja. Disponível em: <http://veja.abril.com.br/ noticia/economia/lucro-da-telefonica-vivo-cresce-apenas-2-2-em-2012>. Acesso em: 21 set. 2015.

27 Referenciado na Teleco. Disponível em: <www.teleco.com.br/Operadoras/ Telefonica.asp>. Acesso em: 21 set. 2015. 
Assim, a Vivo TV, que faz parte do grupo Telefônica Vivo no Brasil, tem atuado na telefonia fixa, móvel, televisão por assinatura, bem como em outros serviços, tornando-se uma das maiores companhias de telecomunicação no país.

\section{Oi TV}

A Oi é resultado da incorporação da Brasil Telecom pela Telemar, sendo que em 2009 a Telemar passou a assumir o controle da Brasil Telecom e em 2010 se dá o processo de integração operacional dos grupos, com atuação em todo território nacional. A empresa possui poder de ação em todos os estados do território nacional, seja na telefonia fixa (Oi Fixo), celular (Oi Móvel), internet (Oi Velox - banda larga -, Oi internet, Ibest e IG - portais de conteúdo e provedores) e TV por assinatura (Oi TV).

Atualmente, a empresa possui em sua composição acionária os seguintes grupos: ${ }^{28}$ Andrade Gutierrez (19,35\%); La Fonte (19,35\%); BNDES (13,08\%); Portugal Telecom (12,07\%); Fundação Atlântico (11,5\%); Previ (9,69\%); Petros (7,48\%); e Funcel (7,48\%).

A Telemar, que tomou o controle da companhia, foi criada no contexto da privatização das telecomunicações no Brasil em 1998, sendo o maior grupo constitutivo dessa empresa denominado Tele Norte Leste S.A. A Telemar, ${ }^{29}$ em sentido inicial, era composta pelas empresas Telemig, Telerj e Telest no Sudeste; Telebahia, Telergipe, Telasa, Telpe, Telern, Teleceará, Telpa e Telepisa no Nordeste; Telamazon, Teleamapá, Telaima, Telma, Telepará no Amazonas, sendo que a integração dessas só foi ocorrer em 2002.

O nome Telemar designava a expressão "tel" de telecomunicações e "mar", que dizia respeito à circunscrição espacial que mar-

28 Referenciado na matéria: "Acordo entre Oi e Portugal Telecom foi alívio para o governo”, publicada em três de outubro de 2013 pelo jornal Folha de S.Paulo e assinada por Natuza Nery. Disponível em: <www1.folha.uol.com.br/mercado/2013/10/1351048-acordo-entre-oi-e-portugal-telecom-foi-alivio-para-o-governo.shtml>. Acesso em: 21 set. 2015.

29 Informações disponíveis no sítio institucional da companhia. 
geava a extensão do litoral brasileiro. Tal empresa também possui atuação em Moçambique, com a Oi Futuro, por meio da instalação de cabos submarinos.

Já a Brasil Telecom S.A. foi resultante das políticas de privatização das telecomunicações em 1998 da Telebrás com a designação de Tele Centro Sul, atuando em estados como: Rio Grande do Sul, Santa Catarina, Paraná na região Sul; Rondônia, Acre, e Tocantins no Norte; Mato Grosso do Sul, Distrito Federal, Goiás e Mato Grosso no Centro-Oeste. Entre os seus principais acionistas estavam o banco brasileiro Opportunity, Telecom Itália, bem como fundos de pensão nacional.

Hoje, conforme informações disponibilizadas pelo sítio da empresa: "A "A Oi é a maior operadora de telecomunicações do país em faturamento e a maior empresa de telefonia fixa da América do Sul com base no número total de linhas".

Nesse sentido, é válido elucidar que a Oi estabeleceu um plano de estratégia espacial em três regiões. Na região I estão presentes os Estados de Minas Gerais, Rio de Janeiro, Espírito Santo, Bahia, Sergipe, Alagoas, Pernambuco, Paraíba, Rio Grande do Norte, Ceará, Piauí, Maranhão, Pará, Amapá, Amazônia, Roraima; na região II comparecem os Estados do Acre, Rondônia, Mato Grosso, Tocantins, Goiás e Mato Grosso do Sul, Paraná, Santa Catarina e Rio Grande do Sul; e na região III o estado de São Paulo.

Também é importante ressaltar que a Anatel permitiu à Oi operar em 2008 serviços de Pay TV no território brasileiro, por meio da tecnologia DTH com o uso de satélite, sendo a primeira oferta do serviço realizada no Rio de Janeiro. Nesse cenário: “[...] O lançamento desse serviço foi realizado em julho de 2009, inicialmente apenas para as cidades do estado do Rio de janeiro. O serviço é oferecido em todo o país com exceção de São Paulo”. ${ }^{31}$

30 Disponível em: <http://ri.oi.com.br/oi2012/web/conteudo_pt.asp?idio$\mathrm{ma}=0 \&$ tipo $=43845 \&$ conta $=28>$. Acesso em: 21 set. 2015.

31 Perfil corporativo da Oi. Disponível em: <http://ri.oi.com.br/oi2012/web/ conteudo_pt.asp? idioma $=0 \&$ conta $=28 \&$ tipo $=43302>$. Acesso em: 21 set. 2015. 
Com isso, a Oi se consolida como a empresa no segmento das telecomunicações no Brasil que mais tem a participação do capital nacional em sua composição acionária, oferecendo uma ampla e variada gama de produtos e atuando também no momento além das fronteiras nacionais na África; em uma estratégia espacial de expansão de suas atividades no segmento, com um lucro líquido em 2012 de 1,785 bilhão de reais, ${ }^{32}$ com 396.000 assinantes $^{33}$ na modalidade de TV paga contabilizados em março de 2013.

Já, presentemente, a Oi se tornou uma das grandes operadoras globais ao anunciar sua fusão com a Portugal Telecom em outubro de 2013, o que coloca a companhia em um novo patamar de atuação, investimento e de negócios. A denominação da nova companhia surgida por meio da fusão entre Portugal Telecom e Oi é de CorpCo e a estimativa é que a empresa tenha 100,6 milhões de clientes no mundo, envolvendo operações no Brasil, Timor, Macau, Namíbia, Moçambique, Angola, Quênia, Angola, São Tomé e Príncipe, Cabo Verde e Portugal com 37,4 bilhões de faturamento. ${ }^{34}$

Tal operação de fusão passou pela análise do CADE (Conselho Administrativo de Defesa Econômica) e pela Anatel, que a aprovaram. Ademais, o BNDES estuda injetar ainda mais recursos na empresa, assim como os fundos de previdência estatal, possibilitando que a CorpCo somasse importante fatia de capital para enfrentar a concorrência nacionalmente e internacionalmente, com o anúncio de novos investimentos e modernização, numa parceria entre o capital privado e estatal.

32 Dado referenciado na Exame. Disponível em: < http://exame.abril.com.br/ negocios/noticias/decisao-favoravel-da-cvm-eleva-lucro-da-oi-em-2012>. Acesso em: 21 set. 2015.

33 Conforme dados do sítio da Oi. Disponível em: <www.oi.com.br/oi/sobre-a-oi/sala-de-imprensa/opcoes/press-releases/detalhe?imprensa $=\mathrm{c} 5 \mathrm{f} 8 \mathrm{~b} 2 \mathrm{c} 55 \mathrm{f}$ 657310VgnVCM10000031d0200a___ Acesso em: 21 set. 2015.

34 Informações referenciadas em: <www1.folha.uol.com.br/mercado/2013/10/ 1351048 -acordo-entre-oi-e-portugal-telecom-foi-alivio-para-o-governo. shtml>. Acesso em: 21 set. 2015. 


\section{Provedores de internet}

A Geografia da internet só é passível de apreensão se levada em conta a história da internet no mundo e o contexto de inserção dessa tecnologia em cada país. Há, nesses termos, uma topologia global da internet que envolve a formação de uma rede de conexão com nós, bifurcações, pontos e muitos outros itens da técnica que permitem a construção e manutenção da sociedade da informação, no período atual, com a construção dos serviços-rede.

A internet tem, portanto, um significado fundamental na sociedade contemporânea, no sentido não só de ligar virtualmente pessoas, instituições, governos, mas de sustentar a economia capitalista no movimento de ganho, perda, acumulação, expansão e crise. Nessa perspectiva, a internet deve ser compreendida não de forma estanque e linear, mas, sim, no quadro geral de sua articulação, lembrando que: "A Internet foi o meio indispensável e a força propulsora na formação da nova economia erigida em torno de normas e processos novos de produção, administração e cálculo econômico [...]" (Castells, 2003, p.49).

A internet está inserida, portanto, no ambiente da inovação, propiciando de forma rápida a difusão de dados e informações, em escala global, por meio de redes-suporte que, estruturadas por meio de satélites e cabos submarinos, ligam um continente ao outro. Com isso, as bolsas de valores são conectadas, notícias chegam instantaneamente, o dinheiro circula globalmente, o comércio é dinamizado, relações sociais são estabelecidas, entre outras formas de produções materiais e imateriais concebidas. Mas também é preciso ter claro que:

O que caracteriza a lógica de interconexão embutida na infra-estrutura baseada da Internet é que os lugares (e as pessoas) podem ser tão facilmente desligados quanto podem ser ligados. A geografia das redes é uma geografia tanto de inclusão quanto de exclusão, 
dependendo do valor atribuído por interesses socialmente dominantes a qualquer lugar dado [...]. (Castells, 2003, p.196)

Nessa afirmação está embutida a constatação de que a Geografia produzida no contexto da internet contém a desigualdade e a seletividade. Os espaços possuem cargas diferenciadas do conteúdo da técnica e, enquanto alguns participam do processo de globalização e mundialização da economia fortemente, outros não estão inseridos totalmente nesse processo. Estes, por sua vez, carecem muitas vezes da infraestrutura técnica ideal para se ligar ao universo das redes de informação e às tecnologias derivadas do processo de inovação e das revoluções logísticas e tecnológicas antecedentes.

Assim, entender o uso dado à internet, bem como a sua manutenção e importância, são também variáveis relevantes para a interpretação de sua produção e apropriação. Há, com isso, corporações que têm por fundamental objetivo prover a seus clientes o acesso à internet de diferentes formas, que são denominados de provedores de internet e, com isso, fazer uso do território. Os provedores fazem, portanto, parte da Geografia da internet ao possibilitarem aos consumidores e aos seus pontos de conexão entrada à rede.

Os serviços, por sua vez, podem ser prestados das mais variadas maneiras e envolvem a distribuição do sinal por via rádio, modem digital, via cabo, fibra óptica, fiação elétrica, satélite entre outras modalidades. Por conseguinte, cada tecnologia agrupa consigo fatores positivos no sentido de sua disseminação e limitações do ponto de vista tecnológico, de sua difusão espacial e acesso.

No mundo, a distribuição da internet é extremamente desigual. Observa-se forte concentração, sobretudo, no hemisfério norte, com destaque para União Europeia, Estados Unidos e Japão. Nesse universo, Pires (2005) traz dados detalhados sobre a morfologia da internet com base na fonte Internet World Stats, ressaltando que:

[...] imensas áreas continentais do planeta estão quase excluídas do acesso à "grande rede mundial de computadores"; já que a África, o Oriente Médio e a Oceania juntos têm o número de pessoas com 
acesso à Internet quase equivalente ao da América Latina. Os Estados Unidos, com 202 milhões dos usuários, ocupa o primeiro lugar entre os dez países com o maior número de usuários da Internet, seguido pela China, com 87 milhões dos usuários. Comparando os dados referentes à população dos países com os usuários da Internet, pode-se perceber o quanto ainda a China que está na segunda colocação do ranking, tende a crescer, já que apenas $11 \%$ de sua população é usuária da Internet < http://www.Internetworldstats. $\mathrm{com} />.^{35}$

Além disso, "Com a marca de 40 milhões, em 2007, o Brasil se tornou o sexto maior usuário mundial de internet. Deixou para trás países como Reino Unido, França e Itália, segundo Organização das Nações Unidas" (Dias; Cornils, 2008, p.137) e, nesse contexto, vai se desenhando no mundo uma Geografia da internet extremamente desigual.

Mesmo no Brasil, há regiões onde o acesso à internet ainda é muito precário e praticamente inexiste, ao mesmo passo em que se têm áreas com estruturas técnicas da informação extremamente densas e relacionadas às lógicas globais de acumulação, seja pela ação das corporações, que operam no segmento de telecomunicação, seja pelas diversas empresas, que usam o território com o fim de desempenhar certa produtividade espacial ou até mesmo especular.

Em Cuba, ${ }^{36}$ por exemplo, país de economia socialista, o acesso comercial à internet ocorre de maneira bem singular. Os serviços de telecomunicações na ilha são efetuados especialmente pela empresa Empresa de Telecomunicaciones de Cuba S.A., que é controla-

35 Disponível em: http://www.ub.edu/geocrit/sn/sn-194-19.htm>. Acesso em: 21 set. 2015.

36 As afirmações referentes a Cuba fazem parte do conjunto de reflexões empreendidas durante o Doutorado Sanduíche realizado pelo autor na Universidad de la Habana, Havana, no segundo semestre de 2012, sob orientação e coordenação dos professores Eliseu Savério Sposito e Eduardo Ramon San Marful Orbis, respectivamente no Brasil e em Cuba. O mesmo foi financiado pela Capes (Coordenação de Aperfeiçoamento de Pessoal de Nível Superior). 
da pelo Estado e gerencia a telefonia fixa e móvel, transmissão de dados, internet, entre outros.

Com fins educativos e sociais, o acesso à internet tem se mantido praticamente exclusivo às instituições de ensino e de saúde, bem como a alguns órgãos estatais e a determinadas residências que possuam membros que trabalhem em setores chaves do governo como na área da saúde, por meio da rede Infomed (Red de Salud de Cuba).

Outra possibilidade de acesso é também feita em hotéis, onde o serviço é tarifado em paridade ao dólar por meio de moeda local (peso convertible), não sendo barato efetuar o seu uso nesses espaços, embora o governo cubano tenha se esforçado, em parceria com a Venezuela, para instalação do cabo submarino ALBA 1, visando a ampliação da oferta e velocidade da internet na ilha.

Segundo a Oficina Nacional de Estadísticas e Información (ONEI), em referência ao ano de 2010, eram 724 mil computadores em Cuba dos quais 434,4 mil estavam conectados a uma rede, sendo 1.790 .000 a quantidade de usuários de serviço de internet e de 150 usuários desse serviço para cada grupo de 1.000 habitantes.

Já no Brasil conforme a pesquisa TIC Provedores (2012):

[...] 35\% dos domicílios possuem computador e apenas 27\% têm acesso à rede mundial de computadores. Isso demonstra que ainda existe uma lacuna entre a posse do computador e o acesso à Internet - aproximadamente 4 milhões de domicílios. Esse dado evidencia que o país está muito distante da universalização do acesso. (TIC Provedores, 2012, p.23)

Para a Pesquisa Nacional por Amostra de Domicílios (Pnad), em 2011, eram 77,7 milhões de usuários de internet no Brasil. Conforme o Ibope, dados mais recentes sobre o terceiro trimestre de 2012 demonstravam 94,2 milhões de usuários de internet no Brasil. O Ibope Nielsen Online também revelou para 2012 no quarto trimestre 52,5 milhões de usuários ativos (acesso em residência) e 
72,418 milhões de pessoas com acesso à internet no Brasil. ${ }^{37}$ Além disso, também é importante destacar cada vez mais a participação de terminais móveis no que diz respeito ao acesso à internet, por meio do uso de aparelhos celulares.

No Mapa 5, é apresentada a proporção de brasileiros, em termos percentuais, que gozam de acesso à internet por região com base na pesquisa TIC Provedores (2012). As regiões Centro Oeste, Sul e Sudeste são as que concentram maior proporção de acesso à internet com $34 \%$ a $50 \%$ da população, seguidas pela região Norte $(17 \%$ a 34\%) e Nordeste (0 a 17\%).

Regiões como Vale do Jequitinhonha com estrutura técnica precária e caracterização socioespacial periférica tampouco poderiam ser incluídas nesse espaço de concentração técnica, mesmo fazendo parte da região Centro Sul. Nesse sentido, é preciso ter em vista que as classificações estatísticas mascaram a realidade empírica e ocultam, muitas vezes, os aspectos qualitativos e geográficos do contexto vivido pela sociedade em um dado momento. Tanto é fato que em São Paulo, estado mais rico da federação, há espaços como a região do Vale do Ribeira e do Pontal do Paranapanema que apresentam grandes fragilidades econômicas.

Assim, se pode mencionar estatisticamente que a região Centro Sul é a que mais concentra o acesso à internet em termos proporcionais a sua população. Na ilustração gráfica que acompanha o Mapa 5 é possível constatar que a maioria das pessoas que acessam a internet tem grau de instrução elevado, ou seja, superior (mais de $80 \%$ ), seguido pelo ensino médio (58\%). Já as faixas etárias que concentram maior proporção de usuários são de 10-15 anos, 16-24 anos e 25-34 anos, ou seja, a internet no Brasil tem um perfil de acesso relacionado ao mundo jovem.

37 Esse parágrafo foi construído com base na leitura dos dados consultados na Teleco. Disponível em: <www.teleco.com.br/internet.asp>. Acesso em: 21 set. 2015. 

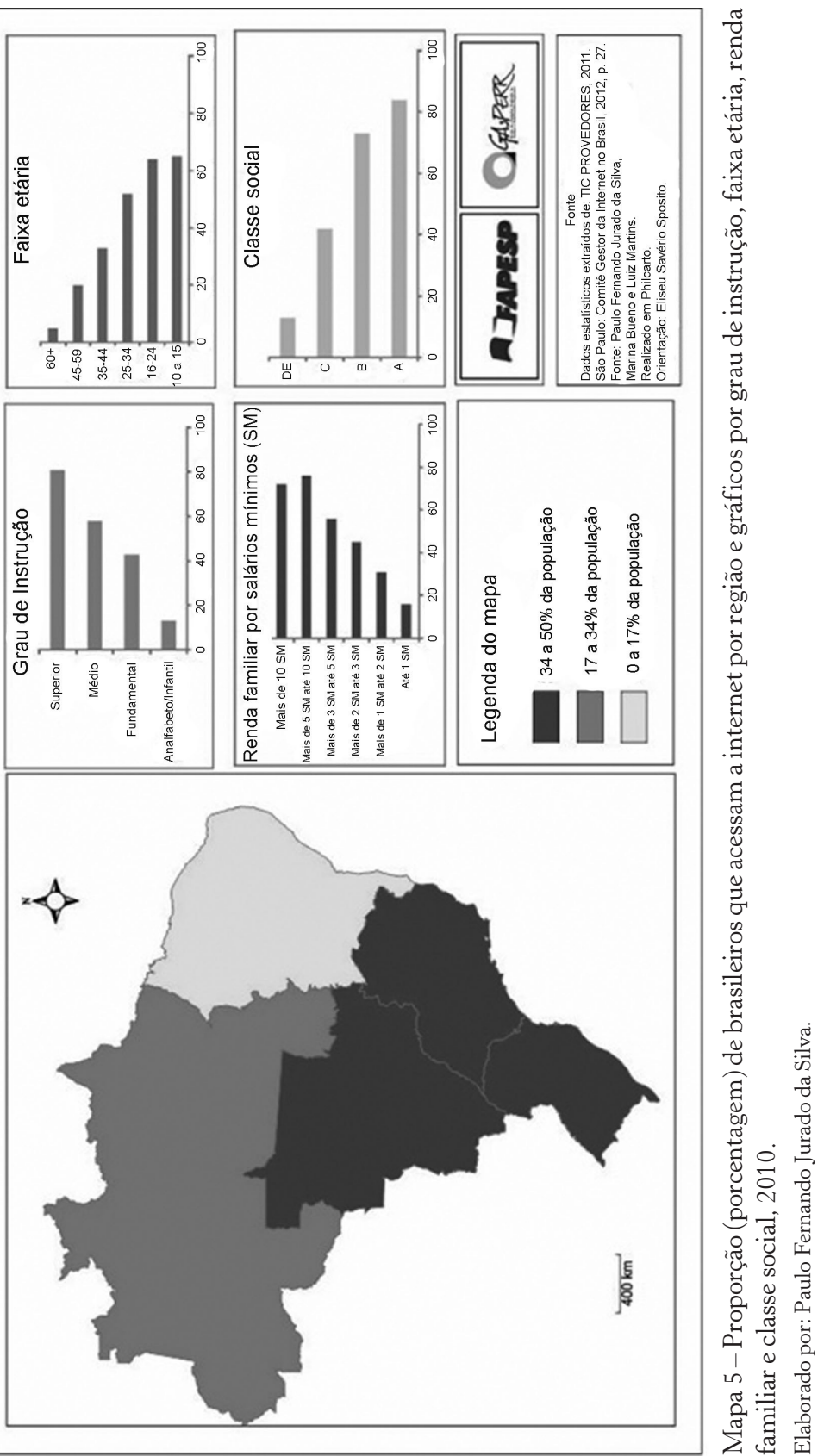
Além disso, tal população situa-se especialmente nas chamadas classes A e B, com rendas superiores aos 10 salários mínimos, mas também por 5 a 10 salários mínimos.

Tal concentração da internet é um dado cumulativo no tempo e no espaço, sendo que a internet surgiu no país no final da década de 1980, ligando instituições de fomento à pesquisa, como a Fapesp e outras instituições de ensino. Nesse período, a internet foi fortemente amparada pelo Estado e teve seu uso praticamente restrito aos órgãos de Estado. Acerca disso, Pires $(2005)^{38}$ relatou detalhadamente o processo de criação da internet do Brasil e a formação de uma morfologia do ciberespaço, descrevendo que:

Dentro desta perspectiva, em setembro de 1988, o Laboratório Nacional de Computação Científica (LNCG) no Rio de Janeiro, anteriormente pertencente ao Conselho Nacional de Desenvolvimento Científico e Tecnológico - CNPq, e atualmente subordinado ao Ministério de Ciência e Tecnologia, foi responsável pela iniciativa do estabelecimento da primeira conexão das instituições científicas brasileiras à rede BITNET, através da Universidade de Maryland, em College Park, usando para isto um enlace de 9.600 bps. Em novembro do mesmo ano, uma segunda conexão, foi procedida às redes BITNET e HEPNET pela Fundação de Amparo à Pesquisa do Estado de SP - FAPESP, que se ligou ao Fermi National Laboratory, em Chicago, a 4.800 bps, esta conexão serviu às instituições universitárias e de pesquisa mantidas pelo governo estadual. A UFRJ empreendeu, em maio de 1989, uma terceira conexão de acesso à rede Bitnet através da UCLA, em Los Angeles, ligando-se de modo semelhante a 4.800 bps (Stanton, 1993). ${ }^{39}$

Ainda segundo Pires $(2005)^{40}$, foi construída uma Rede Nacional de Pesquisa (RNP), reunindo as principais universidades e

38 Artigo não paginado.

39 Disponível em: <www.ub.edu/geocrit/sn/sn-194-19.htm>. Acesso em: 21 set. 2015.

40 Artigo não paginado. 
centros de pesquisa do país, e a velocidade de conexão foi paulatinamente aprimorada e, com isso:

Em 1995, com a expansão da velocidade do trafego da rede ampliada para $2 \mathrm{Mbps}$, a RNP passou a atuar não apenas como uma rede acadêmica, mas também como uma rede com serviços e atividades de caráter privado e comercial [...]. (Pires, 2005, s/p. ${ }^{41}$

Atualmente, visitando a página da Rede Nacional de Ensino e Pesquisa (RNP), observou-se maior complexidade na sua estruturação e ligações mais densas também com o exterior, a exemplo da Cooperação Latino Americana de Redes Avançadas (RedCLARA) e da Géant da Europa. Assim, houve a formação da Rede Ipê, abarcando diversas instituições de ensino e pesquisa e, assim:

A rede Ipêé a primeira rede óptica nacional acadêmica da América Latina, inaugurada pela RNP em 2005. O backbone da rede Ipê foi projetado para garantir não só a largura de banda necessária ao tráfego Internet usual (navegação web, correio eletrônico, transferência de arquivos) mas também o uso de serviços e aplicações avançadas e a experimentação. A infraestrutura engloba 27 Pontos de Presença (PoPs), um em cada unidade da federação, além de ramificações para atender mais de 500 instituições de ensino e pesquisa em todo o país, beneficiando mais de 3,5 milhões de usuários. ${ }^{42}$

Nesse universo, a Rede Ipê firmou parceria com a Oi para oferecer a infraestrutura óptica necessária para o desenvolvimento do projeto, bem como participar de atividades de Pesquisa e Desenvolvimento $(\mathrm{P} \& \mathrm{D})$ em comum.

41 Disponível em <www.ub.edu/geocrit/sn/sn-194-19.htm>. Acesso em: 21 set. 2015.

42 Disponível em: <www.rnp.br/backbone/index.php>. Acesso em: 21 set. 2015. 
Os backbones que compõem a arquitetura da internet, são traduzidos para o português pela expressão "espinha dorsal". Isso significa que designam uma rede de transporte com altíssimo desempenho e tráfego, tanto nacionalmente quanto globalmente, ligando estas a diversos pontos de acesso e servidores, compondo, grosso modo, uma topologia da internet, em escala ampla.

Essa estrutura de backbones conforma, portanto, redes-suporte. Estas, por sua vez, estão diretamente relacionadas com os serviços-rede que são configurados pelos diferentes provedores de internet que possibilitam o acesso dos pontos a essa espinha dorsal complexa, sendo estes no Brasil, em seu momento atual, de origem privada, envolvendo a participação de diversas corporações, estratégias espaciais e econômicas.

São Paulo, por sua vez, continua sendo a metrópole que detém o maior número de ligações com outros municípios, seguida por Rio de Janeiro e Belo Horizonte, na produção de um triângulo geográfico de grande densidade técnica. As redes privadas, nesse contexto, possuem uma topologia distinta daquela formada pela Rede $\mathrm{Na}$ cional de Pesquisa. As redes privadas representam espacialmente o desenho das estratégias das empresas de telecomunicação, envolvidas no processo de dotação de infraestrutura no território, visando à ampliação de seus lucros e à difusão do consumo e da oferta.

As redes privadas inserem sua ação espacial, sobretudo no Estado de São Paulo e na faixa litorânea do país com algumas ramificações mais interioranas, rarefeitas e em alguns casos densas, como é o caso da ligação com Brasília, Belo Horizonte e em outros pontos do território, considerados como estratégicos para operação no uso do território.

Já a Rede Nacional de Pesquisa obedece a uma lógica espacial mais paritária no sentido de distribuir sua espinha dorsal no território. Além disso, é necessário ter em vista que o governo de Dilma Rousseff vem implantando diversas medidas no sentido de popularizar o acesso à internet no Brasil, pensando em um uso menos desigual do território. 
Para tanto, foi criado o Programa Nacional de Banda Larga (PNBL). ${ }^{43}$ Tal medida foi posta em prática por meio da: “[...] publicação do Decreto n. 7.175, de 12 de maio de 2010, que lançou as bases para as ações a serem construídas e implantadas coletivamente $[\ldots]]^{44}$ e, consequentemente, tais:

[...] ações do Programa estão organizadas em quatro grandes dimensões: (i) ações regulatórias que incentivem a competição e normas de infraestrutura que induzam à expansão de redes de telecomunicações; (ii) incentivos fiscais e financeiros à prestação do serviço de acesso em banda larga, com o objetivo de colaborar para o barateamento do custo ao usuário final; (iii) uma política produtiva e tecnológica, capaz de atender adequadamente à demanda gerada pelo PNBL; e (iv) uma rede de telecomunicações nacional, com foco de atuação no atacado, neutra e disponível para qualquer prestadora que queira prestar o serviço de acesso em banda larga. ${ }^{45}$

Logo, a regulação do programa e parte de sua implantação ficará a cabo da Anatel, com diversas ações previstas no período que compreende 2010 a 2014 e, portanto:

Dentre as ações previstas, podem-se destacar um novo plano de universalização do backhaul, ampliando a capacidade disponível e reduzindo o preço, a realização de leilões de radiofrequência para a prestação de banda larga sem fio, com mobilidade, menor preço

$43 \mathrm{Na}$ Argentina, o Governo Federal também implantou um projeto semelhante, em âmbito nacional, através da Arsat (Empresa Argentina de Soluciones Satelitales S.A.) para dotar o território tecnicamente por meio da ação da "Red Federal de Fibra Óptica”, levando uma distribuição mais equilibrada das infraestruturas de telecomunicações, necessárias para difundir a banda larga a diversas partes do país.

44 Disponível em: <www4.planalto.gov.br/brasilconectado/pnbl/implantacao-e-desenvolvimento>. Acesso em: 21 set. 2015.

45 Disponível em: <www4.planalto.gov.br/brasilconectado/pnbl/Implantação-e-desenvolvimento/>. Acesso em: 21 set. 2015. 
e custo de operação mais baixo, bem como, nos leilões de radiofrequência, exigir contrapartidas em investimento em P\&D e em utilização de equipamentos com tecnologia nacional. ${ }^{46}$

Do mesmo modo, outras medidas de suporte foram desencadeadas, visando diminuir as desigualdades regionais, em termos de acesso à internet no Brasil, como ocorreu com a criação da chamada "Rede Nacional". Controlada pela União, esta tem o objetivo de difundir o acesso ao serviço de internet no país, sobretudo, em áreas carentes dessa infraestrutura, ou mesmo nas periferias das grandes capitais onde o serviço é demasiadamente caro, atendendo as pessoas de baixa renda. Além disso, atenderá de modo corporativo ao governo e às instituições públicas, sendo gerida pela Eletrobrás e atendendo 4.278 municípios no período que se estende até $2014^{47}$.

A partir disso, o governo estabeleceu o mapa do que seria a Rede Nacional até 2014, evidenciando que todos os estados estarão cobertos pelo programa. Alguns com maior densidade de fibra óptica, outros com menos, mas valendo a intenção do governo em popularizar a banda larga e ofertar internet de qualidade aos brasileiros e territórios com menores condições econômicas.

Outra medida, ${ }^{48}$ tomada no período recente, visando facilitar o acesso à internet por parte da população brasileira, foi a assinatura da presidenta Dilma do decreto que zera o PIS/Pasep (Programa de Integração Social/Programa de Formação do Patrimônio do Funcionário Público) e o Cofins (Contribuição para o Financiamento da Seguridade Social), que incidem sobre a venda de smartphones, produzidos no Brasil, e que se estendam à faixa de preço de até um

46 Disponível em: <www4.planalto.gov.br/brasilconectado/pnbl/implantacao-e-desenvolvimento/>. Acesso em: 21 set. 2015.

47 Informações obtidas com base na leitura da página oficial do governo: <www4 4 . planalto.gov.br/brasilconectado/pnbl/implantacao-e-desenvolvimento/>. Acesso em: 21 set. 2015.

48 As informações desse parágrafo foram baseadas na consulta da página: <http://exame.abril.com.br/tecnologia/noticias/governo-zera-aliquota-depis-cofins-para-smartphone>. Acesso em: 21 set. 2015. 
mil e quinhentos reais, esperando-se, com isso, uma redução do preço final dessas mercadorias.

Nessa perspectiva, é preciso ter em vista que tais aparelhos têm tecnologia para acessar a internet, facilitando o acesso do consumidor a um produto importante da globalização. Mas a ação também foi pensada para a aquisição dos roteadores digitais que são utilizados para conexão à internet $W i$ - Fi, associados à banda larga fixa.

Todavia, é preciso levar em conta o contexto histórico da questão. Para isso, é necessário frisar que a liberalização da internet no Brasil para uso privado comercial ocorreu em momento anterior, ou seja, a partir do governo Fernando Henrique Cardoso, quando determinadas empresas foram autorizadas a operarem como provedores de acesso à internet.

No mundo, Steda (2012) ${ }^{49}$ relatou que "A década de 1990 começa com a incorporação da Arpa pela NSFNet e o surgimento do primeiro provedor comercial de internet do mundo, o "The World" $[\ldots]$ " e, portanto,

Em 1993, nos Estados Unidos, a Internet deixa de ser uma rede destinada exclusivamente à comunidade acadêmica e passa a ser explorada comercialmente, tanto na construção de backbones privados como para a oferta de serviços. No Brasil este processo ocorreu em 1995 com a abertura de uma portaria conjunta do Ministério das Comunicações e do Ministério da Ciência e Tecnologia, permitindo a criação de provedores de acesso privado e liberando a operação comercial da Internet no Brasil. (Bernardes, 2012, p.175)

Assim:

A expansão comercial de serviços e acessos ao ciberespaço e à Internet favoreceu o crescimento de inúmeras atividades econômicas e o número de internautas no Brasil, e transformou o cibe-

49 Artigo não paginado. 
respaço brasileiro em uma grande estrutura virtual de acumulação [...]. (Pires, 2005) $)^{50}$

Essa estrutura virtual de acumulação é bastante complexa e envolve diversos agentes na produção do espaço virtual, no controle e difusão da informação, dado o universo de provedores que é bastante extenso e a forma como é acessada a internet no Brasil, seja ela móvel ou fixa.

Até 1997, o mercado de provedores no Brasil era bem pequeno, visto que no país não existia uma estrutura fortalecida de clientes e computadores, fazendo com que os provedores atuassem no máximo regionalmente (Bolaño, 2007, p.203). Mas aos poucos essa realidade foi-se alterando com a criação de provedores com presença e destaque nacional, a exemplo do UOL. Monteiro (2008), acerca do assunto ressaltou a formação de grandes grupos nesse período quando escreveu que:

Diante destas dificuldades colocadas pela crescente concorrência, destacaram-se os provedores ligados a grandes grupos de comunicação (UOL - Universo Online, dos grupos Folha e Abril, SOL - SBT Online, do Grupo Silvio Santos, e Nutecnet, do grupo gaúcho RBS), que possuíam posição privilegiada nos mercados de mídia tradicionais e capital para investir no crescimento da mídia on-line, tanto em termos e implantação de infra-estrutura, quanto em capacidade de empreender vultosas campanhas publicitárias off-line, visando estabelecer suas marcas no mercado e conquistar audiência (o que exigia despender grandes somas e dinheiro, que os provedores pequenos não tinham para gastar). Aos que não se inscreviam nestas características, restava a associação com grandes capitais que, já naquele momento, começava a investir na rede de forma semelhante a alguns grupos econômicos ligados a bancos e instituições financeiras, constituindo-se no que se convencionou chamar de "incubadoras de Internet" (a exemplo do GP investi-

50 Artigo não paginado. 
mentos, proprietário do Banco Garantia, que investiu capital no provedor Mandic). (Monteiro, 2008, p.55)

Esse foi o começo de uma disputa marcada não somente pela forte concorrência e pela diversidade de players em ação, contando também rapidamente com a participação estrangeira, ampliando o cenário de concorrência no país e levando muitos empreendimentos à falência. Claro que parte dessas transformações no mercado nacional foram acompanhadas pelo investimento de capital internacional na região, ou seja, na América Latina, e estavam ligadas à estratégias, sobretudo, de gigantes das telecomunicações já consolidadas em outras partes do mundo como se deu com o investimento da Aol no Brasil e em outras partes do continente.

Para se ter ideia desse cenário, poderia se ilustrar essa afirmação com base no trabalho de Monteiro (2008, p.55), o qual destacou a compra do Mandic pelo Impsat Corp (pertencente a Pescarmona da Argentina), o Nutecnet que passou a se chamar Zaz com a ação do grupo RBS, SBT Online (Sol) e Zeek!, a Microsoft com participações na Globo Cabo, entre outras movimentações empresariais e financeiras que se deram nesse momento.

Além disso, internacionalmente, fusões ocorriam entre as empresas de telecomunicações como a Aol e Time Warner. No Brasil, por exemplo, a estratégia da Aol de se firmar no mercado nacional não deu certo, fazendo com que a empresa vendesse sua base de assinantes ao Terra, ${ }^{51}$ que foi o incorporador do Zaz, por outro lado.

Entretanto, há de se destacar que a maior competitividade no mercado de provedores não se deu somente pela chegada do capital externo nesse segmento. Grandes grupos brasileiros ao se fortalecerem nacionalmente passaram a efetuar investimentos na América Latina, a exemplo do que fez o UOL com a compra na Argentina da empresa Sinectis, que passou a se chamar UOL-Sinectis. ${ }^{52}$

51 Disponível em: <http://info.abril.com.br/aberto/infonews/022006/ 01022006-9.shl>. Acesso em: 21 set. 2015.

52 Informação disponível em: <http://noticias.uol.com.br/economia/ultnot/ 2001/09/12/ult82u2635.jhtm>. Acesso em: 21 set. 2015. 
Essas mudanças no mercado de provedores fizeram com que grandes grupos ofertassem acesso à internet gratuitamente como fizeram o IG, Grátis 1, Terra Livre, entre outros. Ao mesmo tempo, houve a chegada de outros players internacionais no mercado, como ocorreu com a StarMedia e:

Ainda em 2000, às vésperas da crise, entraram em funcionamento os portais Globo.com e Estadao.com.br, ambos com grande poder de veiculação on-line e potencial de crescimento para fazer frente ao líder UOL. A inauguração do portal do grupo Estado de São Paulo, principal concorrente local do Grupo Folha, foi uma surpresa para o mercado que dava como certa uma associação com o portal Terra/ ZAZ. O portal do grupo Globo, por sua vez, já nasceu com um potencial de fornecimento de conteúdo tão grande ou maior que o UOL, sendo relativamente privilegiado em virtude de ter recebido importantes inversões financeiras internacionais, além de possuir uma considerável visibilidade e respaldo de publicidade diante da ampla estrutura das Organizações Globo de televisão. (Monteiro, 2008, p.58)

Tais movimentações tornaram o mercado de internet no país ainda mais competitivo e muitos provedores tiveram que fechar suas portas nos anos 2000. Já, atualmente, sob coordenação executiva de Alexandre F. Barbosa pelo Comitê Gestor da Internet no Brasil (2012, p.28) com base na pesquisa TIC Provedores 2011 foi descrito que:

[...] existem 1.934 provedores de serviços de Internet (PSI) formais no Brasil, responsáveis por quase todos os acessos no país. Outro destaque da pesquisa é que esses quase 2 mil provedores possuem 17 milhões de clientes, ou seja, existem 17 milhões de conexões residenciais e empresariais de banda larga fixa no país - e não estão contabilizadas nesse número as conexões via acesso discado e de Internet móvel.

Nesse cenário, a pesquisa demonstrou ainda que os grandes provedores são aqueles que possuem mais de novecentos mil clien- 
tes, ressaltando que seis grandes provedores são os responsáveis por atender $78 \%$ do mercado. O Sudeste é a região que concentra maior número de provedores, seguido pela região Sul, Nordeste, Centro-Oeste e Norte. Em referência à mesma pesquisa, o Núcleo de Informação e Coordenação do Ponto BR (2011) ${ }^{53}$ descreveu que:

A pesquisa não diz, mas os maiores provedores de internet no país são a Telefônica, a Oi, a Net, a GVT, a Embratel e a CTBC Telecom. O mercado também é concentrado regionalmente (43\% dos provedores atuam na região Sudeste e somente 6\% na Norte) e socialmente (90\% da classe A e $65 \%$ da classe B tinham conexão à internet em 2010, comparados com 24\% da classe C). Esses dados, com exceção do último, que faz parte da TIC Domicílios, foram apresentados hoje pelo Núcleo de Informação e Coordenação do Ponto BR (NIC.br). Foram recolhidos pela TIC Provedores, o primeiro censo de provedores de serviços internet realizado no Brasil. ${ }^{54}$

Nesse sentido, o Teleco, em 2011, revelou o Market Share $e^{55}$ (vide Tabela 3) dessas operadoras e expôs que a Oi possuía maior porcentual (30,20\%), seguida pela NET 25,70\%, Telefônica/Vivo 22,20\%, GVT 10,20\% e CTBC 1,70\%. Tais provedores para o Teleco (2013) foram colocados na categoria SCM (Serviço de Comunicação Multimídia) e possuíam ampla gama de serviços e ofertas aos seus clientes.

Além disso, é preciso ter em vista que:

No acesso à Internet a partir da residência ou de uma pequena empresa estão envolvidos dois tipos de provedores de serviço:

53 Artigo não paginado.

54 Disponível em: <www.nic.br/imprensa/clipping/2011/midia1221.htm>. Acesso em: 21 set. 2015.

55 Este termo em inglês descreve a quota de mercado ou, em outras palavras, a participação das operadoras no segmento. 
- Provedor de acesso à Internet, é provedor de serviços de valor adicionado, que tem a função de conectar um computador (PC, por exemplo) à Internet permitindo a navegação na World Wide Web e acesso a serviços como envio e recebimento de e-mail.

- Provedor de serviço de telecomunicações que fornece a conexão entre a residência (ou escritório) e o local onde estão localizados os servidores do provedor de acesso a Internet. Esta conexão pode ser discada, fornecida pelas operadoras de telefonia fixa, ou Banda larga oferecida por operadoras de SCM. ${ }^{56}$

Já UOL, Terra, IG, e Globo entram na categoria de provedores de acesso à internet, auxiliando na navegação na internet, dependendo, portanto, dos provedores de serviço de telecomunicações que, consequentemente, são oferecidos por operadoras SCM.

Tabela 3 - Market Share anual de banda larga no Brasil.**

\begin{tabular}{c|c|c|c|c}
\hline Milhares & $\mathbf{2 0 0 8}$ & $\mathbf{2 0 0 9}$ & $\mathbf{2 0 1 0}$ & $\mathbf{2 0 1 1}$ \\
\hline Oi & $38,18 \%$ & $37,00 \%$ & $31,60 \%$ & $30,20 \%$ \\
\hline Net & $22,15 \%$ & $25,30 \%$ & $25,50 \%$ & $25,70 \%$ \\
\hline $\begin{array}{c}\text { Telefônica/ } \\
\text { Vivo }\end{array}$ & $25,53 \%$ & $23,20 \%$ & $24,00 \%$ & $22,20 \%$ \\
\hline GVT & $4,54 \%$ & $5,90 \%$ & $7,90 \%$ & $10,20 \%$ \\
\hline CTBC & $2,13 \%$ & $1,80 \%$ & $1,70 \%$ & $1,70 \%$ \\
\hline Embratel & -- & -- & -- & $2,60 \%$ \\
\hline Outras & $7,48 \%$ & $6,80 \%$ & $9,20 \%$ & $7,50 \%$ \\
\hline Total & 10.010 & 11.380 & 13.799 & $100,00 \%$ \\
\hline
\end{tabular}

Fonte: Operadora, Anatel, Teleco.

* Estimado pela Teleco.

Extraído da Teleco. Disponível em: <www.teleco.com.br/blarga.asp>. Acesso em 21 set. 2015

56 Disponível em: <www.teleco.com.br/internet_prov.asp>. Acesso em 21 set. 2015. 
No universo dos pequenos provedores, a principal forma de acesso para conexão à internet é feita via rádio. A tecnologia por modem digital e modem a cabo, na proporção de clientes por tecnologia, correspondiam respectivamente a $57 \%$ e $23 \%$ e a tecnologia via rádio $7 \%$, seguida pelas demais tecnologias com cifra igual ou inferior a 5\% do total (TIC Provedores, 2011, p.33).

Finalmente, a presente investigação procurará dar luz especialmente aos provedores mais expressivos de acesso à internet, visto que ainda existiria uma variedade muito ampla de provedores e de modalidades de acesso à internet móvel e fixa, envolvendo empresas operadoras de dados com investimentos em outros segmentos, a exemplo AES Eletropaulo, Geodex, Cemig Telecom etc.

\section{UOL}

Considerado como um dos provedores pioneiros de acesso à internet no Brasil, o UOL teve sua entrada no mercado em abril de 1996. Na atualidade, o Universo Online representa o maior portal de conteúdo no Brasil, abarcando diversas publicações de revistas e jornais.

A Editora Abril participou da composição acionária do UOL e inclusive era proprietária do portal Brasil Online (BOL), que foi incorporado pelo UOL, configurando-se depois dessa fusão como principal portal de conteúdo do país.

Monteiro (2008, p.53), avaliando a internet comercial no Brasil, procurou destacar que a consolidação do UOL como um dos principais provedores ocorreu porque:

Para implantar o maior serviço on-line em língua não-inglesa do mundo em apenas dois anos, o Grupo Folha adotou estratégias de atuação baseadas em três princípios: (1) primeiro, incorporou as tendências tecnológicas lançadas no mercado de Internet, adaptando-as ao ritmo e às características da rede no Brasil; (2) 
segundo, identificou o momento certo para implementar conceitos que o mercado de mídia internacional já estava utilizando, como o de alianças estratégicas com grupos concorrentes; (3) e terceiro, colocou em prática uma política consistente de produção de conteúdo que sintetizasse o conceito de serviço, informação e entretenimento. A fórmula só foi bem sucedida graças ao poder de capitalização do Grupo Folha e de seu sócio no empreendimento, o Grupo Abril. (grifo do autor)

Aliando conteúdo e marca forte, o UOL rapidamente foi ganhando espaço no mercado nacional e construindo uma imagem que se mistura com o nascimento da internet comercial no país. Além disso, a estratégia de possibilitar ao provedor ainda maior controle pelo Grupo Folha possibilitou a empresa de criar uma identidade própria com uma linha editorial e de conteúdo bem definida e, com isso, "[...] o Universo Online impôs a si um ritmo de crescimento acelerado, só comparado ao ritmo do crescimento da rede no Brasil, que entre os anos de 1996 e 1997 chegou a ser superior a $100 \%$ ao ano." (Monteiro, 2008, p.54)

Já no presente, segundo consta nas informações do texto "UOL recompra ações para fechar o capital”, publicado pelo jornal O Estado de S. Paulo (2011), o UOL passou a ter capital fechado. O controle da empresa é efetuado pelo grupo Folhapar S.A, tendo como acionista importante o grupo Hypermarcas, que adquiriu a participação do Grupo Portugal Telecom.

Dessa forma, tendo em vista o sítio do UOL, observou que "Segundo o Ibope, o portal é líder no país, alcançando uma audiência superior a 34,3 milhões de visitantes únicos e mais de 4,9 bilhões de páginas vistas por mês". ${ }^{57}$ Além disso, vale sublinhar que:

57 Disponível em: <http://sobreuol.noticias.uol.com.br/>. Acesso em: 21 set. 2015. 
O UOL teve 24,183 milhões de visitantes únicos domiciliares mensais em média em 2011, segundo o Ibope. Em novembro, chegou a 25,5 milhões de visitantes. Pelo critério de audiência residencial somada à audiência em ambientes corporativos, o UOL teve média de 31,511 milhões de visitantes únicos mensais em 2011.

O UOL registrou média mensal de 2,762 bilhões de páginas vistas em residências em 2011. Pelo critério de residência mais trabalho, a média mensal do ano sobe para 4,769 bilhões de páginas vistas. ${ }^{58}$

Desse modo, o UOL se consolida como um dos principais veículos de conteúdo da internet brasileira, proporcionando a seus clientes o acesso atualizado de seu portal com diversos canais de comunicação. Sua estrutura conta com notícias, música, televisão online (TV UOL), jogos virtuais, bate-papo, entretenimento, economia etc.

Por fim, é válido ressaltar que a receita líquida, em 2010, do UOL era de 817 milhões de reais ${ }^{59}$. Além disso, no momento, o provedor conta com 2,5 milhões de assinantes nas modalidades de conteúdo, serviços e produtos da empresa, destinando aos seus clientes o mais amplo conteúdo em língua portuguesa do mundo, ${ }^{60}$ em páginas e serviços, sendo líder no segmento.

\section{Terra Networks Brasil S.A.}

O Terra é um dos provedores pioneiros no Brasil e sua estreia no mercado ocorreu em 1999. O empreendimento é o resultado do investimento do grupo Telefónica da Espanha em diversos países com a incorporação de provedores locais, reunindo países da América Latina, Estados Unidos e Espanha.

58 Disponível em: <http://sobreuol.noticias.uol.com.br/historia/audiencia. jhtm>. Acesso em: 21 set. 2015.

59 Disponível em: <www.teleco.com.br/internet_prov.asp>. Acesso em: 21 set. 2015.

60 Disponível em: <http://imprensa.uol.com.br/>. Acesso em: 21 set. 2015. 
Acerca desse momento poderia destacar que o provedor se tornou uma grande empresa "[...] through the aggressive acquisition of several local startups in Spain and the main Latin American markets: Olé (Spain), Zaz (Brazil), Infosel (Mexico), Gauchonet, Donde (Argentina) and Chevere (Venezuela)" ${ }^{61}$. Com isso, o portal foi ganhando cada vez mais presença espacial em diversos países, voltando-se ao público latino-americano e:

Hoje, o Terra é líder regional em Internet: está em 17 países da América Latina, além dos EUA. Conteúdo e serviços são distribuídos na Argentina, Brasil, Chile, Colômbia, Costa Rica, Equador, El Salvador, Guatemala, Honduras, México, Nicarágua, Panamá, Peru, Porto Rico, República Dominicana, Uruguai e Venezuela. ${ }^{62}$

No caso brasileiro, o Terra incorporou o Zaz, que era resultado da ação do grupo RBS e Nutecnet do Rio Grande do Sul. O Zaz já tinha acumulado prestígio na ocasião, reunindo diversos serviços relacionados à internet como buscador, disponibilizando notícias de grandes grupos no Brasil, a exemplo do jornal O Globo, Agência Estado, entre outros.

Em um primeiro momento "[...] foi formada uma joint-venture com a RBS e com Marcelo Lacerda e Sérgio Pretto, a Terra Networks e, em dezembro de 1999, o Zaz virou Terra". ${ }^{63}$ Mais adiante, "Em outubro de 2000, nasceu a Terra Lycos, a partir da união da Terra Network S/A com a norte-americana Lycos Inc., e em 2004 o Terra vendeu o Lycos. ${ }^{64}$ "

61 Extraído de: <http://en.wikipedia.org/wiki/Terra_Networks>. Acesso em: 21 set. 2015.

62 Disponível em: http://publicidade.terra.com.br/index.php/pagina/visualizar/1>. Acesso em: 21 set. 2015.

63 Extraído de: <http://tecnologia.terra.com.br/internet10anos/interna/0,,OI542329-EI5029,00.html>. Acesso em: 21 set. 2015.

64 Extraído de: <http://tecnologia.terra.com.br/internet10anos/interna/0,,OI542329-EI5029,00.html>. Acesso em: 21 set. 2015. 
No Brasil, o provedor ainda ampliou seus negócios comprando a base de assinantes da Aol, segundo notícia veiculada pelo jornal $O$ Estado de S. Paulo, em 2006, quando descrito que o provedor: "[...] apresentou à Comissão de Valores Mobiliários norte-americana uma proposta de venda de suas base de clientes ao Terra Networks. Segundo o documento, o provedor de acesso à internet estaria disposto a pagar até US\$1,9 milhão pelo negócio." ${ }^{65}$

Atualmente, a audiência do Terra é de 98 milhões de pessoas no mundo, 52 milhões de pessoas no Brasil com presença na web, mobile, Broadband TV, entre outros com compra de direitos esportivos como as Olimpíadas, entretenimento e musicais. ${ }^{66}$ Só o canal de música, em 2009, atingia 3 milhões de ouvintes com mais um milhão de músicas disponibilizadas.

O perfil da audiência regional tem São Paulo como principal centro consumidor (30\%), seguido pelo interior de São Paulo (21\%), Rio de Janeiro (7\%) e os demais porcentuais divididos entre os outros estados da federação. Nesse universo, 68\% da audiência pertenciam as classes A e B. ${ }^{67}$

Em termos de faturamento, conforme dados obtidos no Teleco, ${ }^{68}$ o Terra, em 2007, totalizou 767 milhões de reais (receita bruta), com 2,4 milhões de assinantes (segundo trimestre de 2007) e na banda larga perfazendo a base de 1,9 milhão de assinantes.

\section{Internet Group (IG)}

O Internet Group (IG) iniciou suas atividades como provedor no Brasil em 2000. O portal e provedor foi uma parceria do grupo

65 Extraído de: <www.estadao.com.br/arquivo/tecnologia/2006/ not20060103p71047.htm>. Acesso em: 21 set. 2015.

66 Informações disponíveis em: <http://publicidade.terra.com.br/index.php/ pagina/visualizar/1>. Acesso em: 21 set. 2015.

67 Informação disponível em: <http://publicidade.terra.com.br/index.php/ audiencia/index $>$. Acesso em: 21 set. 2015. A fonte é da TGI Target Group.

68 Informação disponível em: <www.teleco.com.br/internet_prov.asp>. Acesso em: 21 set. 2015. 2013. 
Opportunity e GP Investimento, além de contar com a participação do publicitário Nizan e do jornalista Matinas e Mandic. ${ }^{69}$

A estratégia principal da companhia de ofertar acesso à internet gratuita funcionou perfeitamente e aos poucos o portal ganhava uma das maiores audiências da internet brasileira, bem como uma base de clientes relevante, sendo essa gratuita ou paga.

Agregando uma estrutura de atualização de notícias em seu portal com rapidez, a exemplo do jornal eletrônico denominado "Último Segundo", conseguiu alcançar a fórmula da agilidade aos seus serviços. $\mathrm{Na}$ audiência ${ }^{70}$ do IG, $84 \%$ dos usuários do portal o acessam para ler notícias, sendo que $66 \%$ pertencem às classes $\mathrm{A}$ e $\mathrm{B}$ e 53\% tem como formação o ensino superior e técnico.

Além disso, aos poucos a composição acionária do IG foi se alterando, sendo que "[...] Em 2004, a Brasil Telecom comprou o iG, que foi fundido aos portais iBest e BrTurbo. Desde 2010, o portal pertence à Oi, que também se tornou dona da Brasil Telecom". ${ }^{71}$ Entretanto, em 2012 houve alteração igualmente no portal, uma vez que:

Após inúmeros rumores, a venda do portal de internet iG foi confirmada, nesta quarta-feira, para o grupo português Ongoing, que no Brasil detém participação nos jornais Brasil Econômico, Marca Brasil e Meia Hora, conforme informou EXAME.com. A Ongoing será dona do braço de conteúdo e publicidade do iG; os demais negócios ficarão com a Oi. ${ }^{72}$

69 A composição acionária inicial da empresa foi extraída da página: <http:// aniversario10anos.ig.com.br/10+anos+ig.html>. Acesso em 21 set. 2015.

70 A audiência foi extraída de: <http://centraldoanunciante.ig.com.br/audiencia/ig/5072fa1e335da41e52000389.html>. Acesso em: 21 set. 2015.

71 Citação extraída de: <http://exame.abril.com.br/tecnologia/noticias/antes-deser-vendido-ig-caiu-no-ranking-dos-portais-da-web>. Acesso em: 21 set. 2015.

72 Disponível em: <http://exame.abril.com.br/negocios/aquisicoes-fusoes/ noticias/ig-e-ongoing-tracam-plano-de-transicao-de-60-dias/>. Acesso em: 21 set. 2015 . 
O grupo Ongoing tem sido um dos mais importantes de Portugal e pertence à família Rocha dos Santos. "Em 1989, o grupo integrava 25 empresas, empregava 1.500 pessoas e tinha vendas superiores a 20 milhões de contos (cerca de 100 milhões de euros), o que representava 0,2 por cento do produto interno bruto (PIB) português." 73 Em 2004, o grupo passou a se chamar Ongoing Strategy Investments e tem concentrado seus investimentos no mercado de língua portuguesa, com destaque para o Brasil.

Para o Teleco, ${ }^{74}$ no terceiro trimestre de 2008 eram 4 milhões de usuários de internet discada na Brasil Telecom e no primeiro trimestre de 2007 correspondiam a 348 mil assinantes de banda larga no IG e 812 mil no BR Turbo.

\section{Globo.com}

O portal e provedor Globo.com pertence às organizações Globo, com sede no Rio de Janeiro. Lembrando que esse grupo é o maior no segmento de mídia no país e na América Latina, com investimentos nos mais variados setores da comunicação, como jornais, televisão, revistas, entre outros.

Segundo a companhia Alexa, ${ }^{75}$ que mede os acessos a sites na internet, depois do UOL, a Globo é o segundo portal de origem de capital brasileiro mais acessado no país. Assim, o portal da Globo oferece aos seus usuários acesso às informações do canal aberto Globo, notícias, entretenimento, entre outros. Para More et al. (2010):

A história do portal Globo.com teve início na década de 1990, mais especificamente no dia 21 de dezembro de 1998, quando o

73 Citação extraída de: <www.ongoing.com/quemsomos.html>. Acesso em: 21 set. 2015.

74 Informação disponível em: <www.teleco.com.br/internet_prov.asp>. Acesso em: 21 set. 2015.

75 Disponível em <www.alexa.com/topsites/countries/BR>. Acesso em: 21 set. 2015. 
portal passou a estar presente na rede mundial de computadores no endereço virtual http://www.globo.com. Sua proposta é a de oferecer a seus leitores tudo sobre o conteúdo e marcas das Organizações Globo, através de sites altamente interativos com conteúdos exclusivos. (More et al., 2010, p.355)

No site do portal Globo.com é possível ver que o provedor opera tanto na modalidade paga quanto gratuita. Assim, o portal disponibiliza acesso a vários canais de comunicação com destaque para o G1, dedicado à divulgação de notícias, Globoesporte.com, voltado ao mundo do esporte, Gshow, aos programas de entretenimento, novelas e séries da Globo, entre outros.

Em termos de audiência, observa-se no portal ${ }^{76}$ que a home page da Globo.com conta com 57 milhões de visitantes únicos, 1,2 bilhão de páginas visitadas por mês, com tempo online de 18 minutos e 23 segundos, dos quais $61 \%$ pertencem à classe A e B. Isso sem mencionar os demais sítios que compõem a estrutura do portal e provedor que ocupam posição importante na audiência brasileira.

\section{Telefonia celular}

A telefonia celular, igualmente conhecida como telefonia móvel, possibilitou a localização de pessoas no espaço em sentido oposto ao que sustentava a telefonia fixa, que não permitia a comunicação da informação por meio da mobilidade espacial e geográfica em ondas. Tal tecnologia permitiu acessar indivíduos no espaço e não associar o telefone a um local específico de chamada e recepção, como ocorre com a telefonia fixa. Essa ideia se relaciona, portanto, à localização

76 As informações foram coletadas de: <http://anuncie.globo.com/mediakit/ globocom/home-globocom.html>. Acesso em: 21 set. 2015. A fonte da audiência é baseada no Google Analytics - dez/11 e o perfil por classe social do Ibope Nielsen Online - Dezembro 2011, conforme veiculado na página em questão. 
de pessoas e não à conexão de locais. As pessoas se tornam "entidades espaciais", ou geograficamente localizadas, em termos de práticas sociais, bem como de conteúdo produzido e apropriado, nas formas diversificadas da comunicação.

A tecnologia celular possibilitou, consequentemente, ao longo do tempo, a integração de serviços que antes eram oferecidos separadamente por meio de diferentes objetos técnicos em um único aparelho. Ou seja, no celular se tem hoje também a TV e a internet. De todas, no momento, é a mais popular e com maior disseminação na sociedade brasileira.

Em outras palavras, das tecnologias da comunicação disponíveis no mercado é a que apresenta maior amplitude de usuários e a mais popular, envolvendo celulares pré-pagos e pós-pagos. Para o IBGE, na Pesquisa Nacional por Amostra de Domicílios (Pnad, 2005, p.61):

A posse de telefone móvel celular para uso pessoal mostrou-se mais difundida na população do que o acesso à Internet. No total de pessoas de 10 anos ou mais de idade, 36,7\% tinham telefone móvel celular para uso pessoal.

Já para a Pnad, referente a 2011, ${ }^{77}$ os dados:

[...] mostraram que o contingente de pessoas de 10 anos ou mais de idade que tinham telefone móvel celular para uso pessoal foi estimado em 115,4 milhões, o que correspondia a 69,1\% da população. Frente a 2005, quando havia 55,7 milhões de pessoas que possuíam esse aparelho, ou $36,6 \%$ da população, o crescimento foi de 107,2\%. No mesmo período, a população de 10 anos ou mais de idade do

77 Divulgada no sítio eletrônico do IBGE em 16 de maio de 2013. Disponível em: <www.ibge.gov.br/home/estatistica/populacao/acessoainternet2011/ default.shtm>. Acesso em: 21 set. 2015. 
país cresceu 9,7\% de 152,3 milhões de pessoas em 2005 para 167,0 milhões de pessoas em 2011. (IBGE, 2013, p.43)

Assim, o panorama é de crescimento do setor com a entrada maciça de novos consumidores que passam a adquirir tais aparatos da tecnologia. Por conseguinte, baseando-se em dados disponibilizados pela Anatel, é possível mostrar no Mapa 6 e na Tabela 4 a quantidade de acessos por plano de serviço de telefonia celular, segundo as unidades da federação no Brasil.

Nessas duas ilustrações é possível identificar que a região que concentra maior número de acessos é a Sudeste, com 87.314.644 acessos no serviço pré-pago e 29.060.885 no pós-pago, permitindo interpretar as desigualdades socioespaciais do país face aos dados dessa tecnologia móvel.

Em todos os estados da federação há o predomínio do serviço pré-pago, sendo São Paulo e Minas Gerais os estados com maior quantidade de acessos no Brasil. No conjunto do Brasil, a região que apresenta a menor quantidade de acessos é a região Norte do país, sendo os Estados de Roraima, Amapá e Acre os com menor quantidade de acessos.

Nesse sentido, é preciso ter em vista que a telefonia celular apresenta uma topologia particular no campo das telecomunicações e, portanto, o local de cobertura da rede móvel é organizado em células de propagação. Além disso, hoje é possível que determinadas pessoas se mantenham online todo o dia, se desejar, por meio da tecnologia $3 \mathrm{G}$ ou $4 \mathrm{G}$ da telefonia, favorecendo cada vez mais a integração da economia, nos chamados serviços avançados que envolvem o comércio eletrônico e o comércio corporativo, lembrando que: "[...] Serviços como finanças, seguros, consultoria, serviços legais, contabilidade, publicidade e marketing formam o centro da economia do século XXI” (Castells, 2003, p.187). 


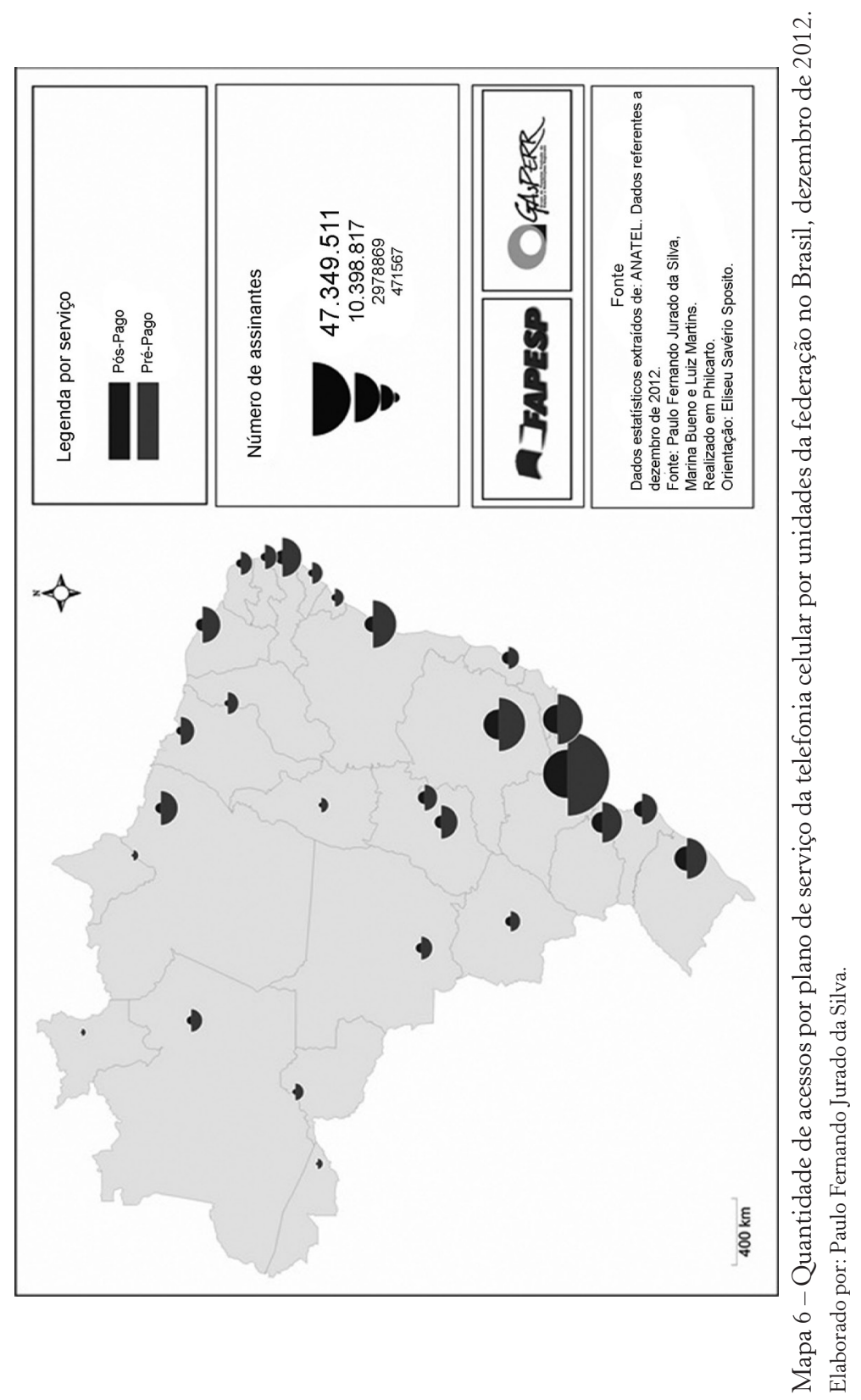




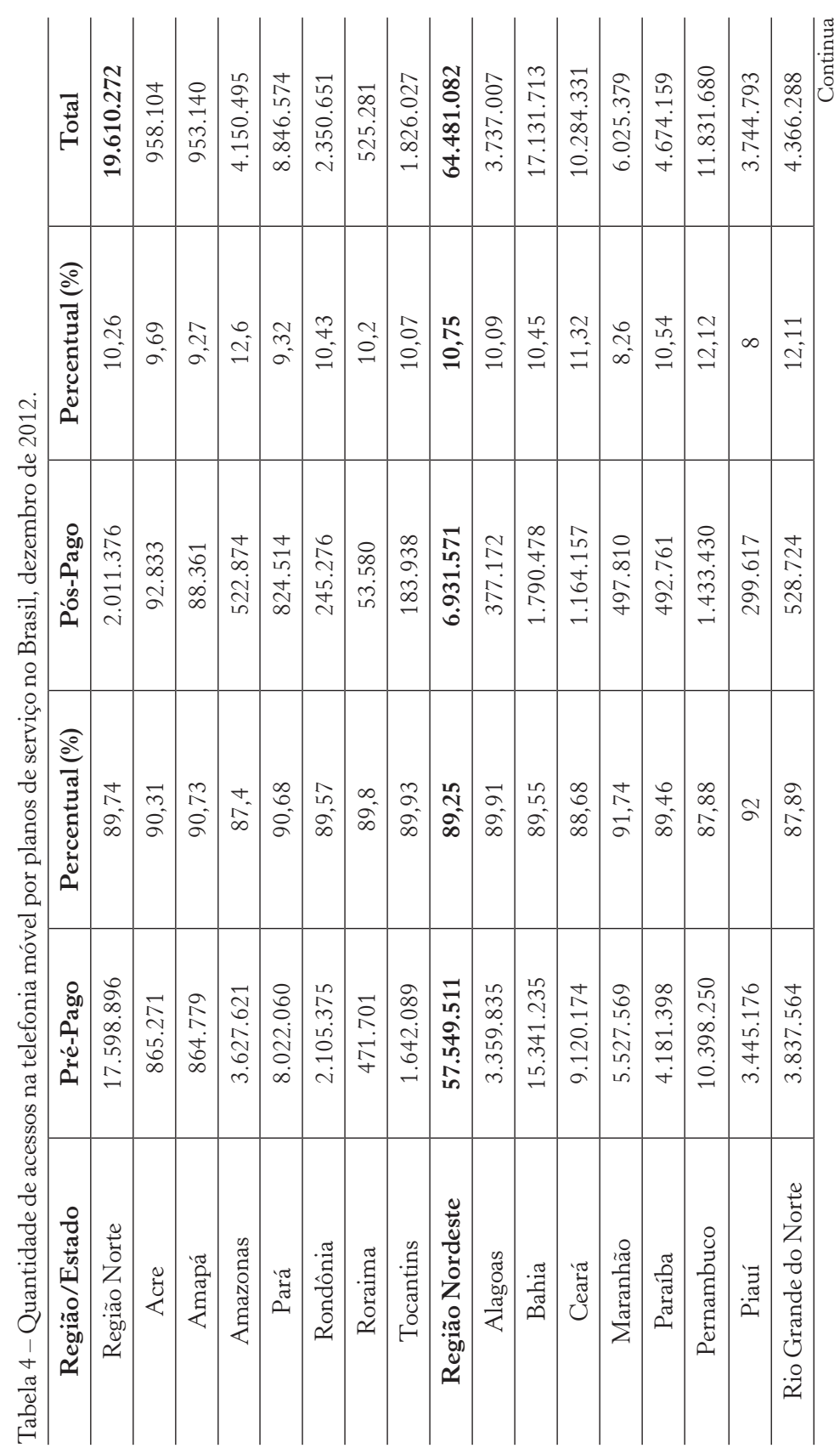




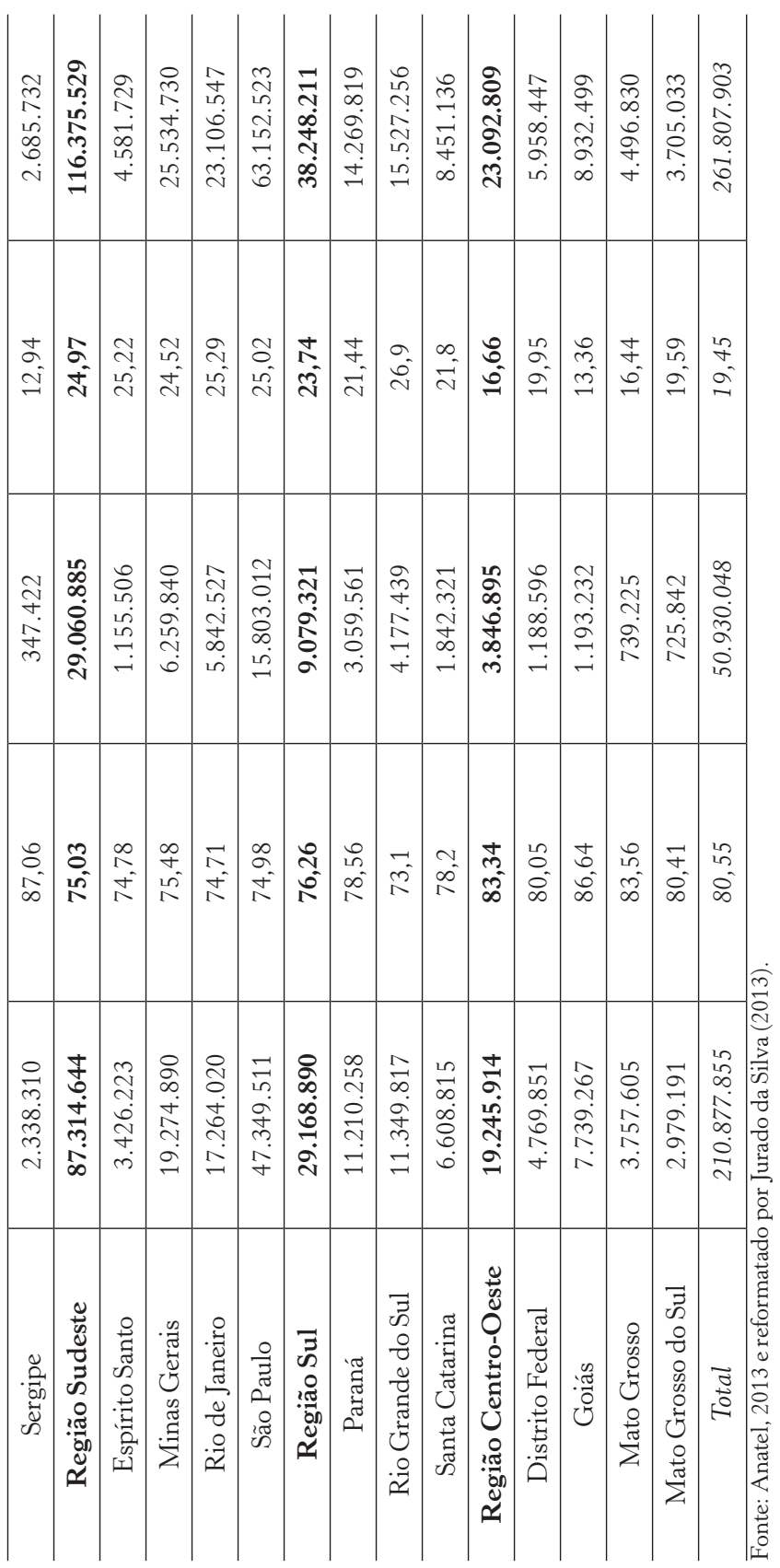


É preciso, entretanto, ressaltar que para essa tecnologia possa existir é necessária uma série de aparatos para dar suporte a esse quadro do ponto de vista material e geográfico, a exemplo das Estações Rádio Base (ERB) ou cell sites. Tais estações, por sua vez, dão sustentação ao processo das telecomunicações móvel e apresentam grande difusão no território, podendo ser entendidas do ponto de vista da sua organização como redes-suporte do serviço de telefonia móvel. Sobre o assunto Silva e Toledo Junior (2010, p.3) descreveram que:

Segundo a ANATEL (2009), hoje no Brasil existem 44.595 Estações Rádio Base (ERBs) espalhadas em seu território. Estas estações são necessárias para o funcionamento do Sistema de Telefonia Móvel Terrestre Público (STMTP), pois são as ERBs as responsáveis pela emissão/recepção entre as estações móveis (os aparelhos celulares), bem como os terminais de Controle.

Com isso, esta mobilidade tem seus limites e se circunscreve aos pontos e áreas onde há a presença de sinal e deste aparato técnico. Em termos técnicos:

Esta mobilidade é conseguida pela utilização de comunicação wireless (sem fio) entre o terminal e uma Estação Rádio Base (ERB) conectada a uma Central de Comutação e Controle (CCC) que tem interconexão com o serviço telefônico fixo comutado (STFC) e a outras CCCs, permitindo chamadas entre os terminais celulares, e deles com os telefones fixos comuns. ${ }^{78}$

78 Disponível em: <www.teleco.com.br/DVD/PDF/tutorialcelb.pdf>. Acesso em: 21 set. 2015. 
E, portanto:

O terminal móvel se comunica com a ERB mais próxima. A área de cobertura referente a uma ERB é chamada de célula. Ao se locomover o terminal móvel muda de célula e tem sua comunicação transferida de uma ERB para outra. A mudança de ERB durante uma chamada é denominada "handover".

[...] Quando o terminal está fora de sua Área de Mobilidade ele está em roaming, ou seja, ele é um assinante visitante no sistema celular daquela região. ${ }^{79}$

ERBs e CCCs são entendidas, portanto, na literatura geográfica como aparatos que constituem as "redes-suporte" da telefonia móvel posicionando, portanto, tal compreensão a partir da contribuição conceitual de Curien e Gensollen (1985). A leitura das redes-suporte permite, nesse sentido, distinguir uma topologia das telecomunicações móveis no Brasil, mantendo íntima ligação com os "serviços-rede", que se relacionam diretamente às empresas de telecomunicação no uso corporativo do território.

Segundo Silva e Toledo Junior (2010, p.4) a distribuição das ERBs no Brasil é bastante desigual. Elas se concentram, sobretudo nas grandes capitais do país e na faixa litorânea, perdendo expressividade no interior do território. São Paulo, nesse cenário, será o Estado que mais concentrará esses objetos técnicos, seguido por Minas Gerais, Rio de Janeiro, Paraná e Rio Grande do Sul.

Com isso, observando a Tabela 5, verificar-se-á que a empresa Claro é a que concentra maior número de estações rádio base no território, com 14.454 estações, seguida pela Vivo (14.115), Oi (13.684) e Tim (12.789), além de outras empresas que possuíam o patamar inferior a 4.000 estações como Nextel, CTBC, Sercomtel e Aeiou.

79 Disponível em: <www.teleco.com.br/DVD/PDF/tutorialcelb.pdf>. Acesso em: 21 set. 2015. 
Tabela 5 - Estações Rádio Base no Brasil, 2012.

\begin{tabular}{c|c}
\hline Operadoras & Número de estações \\
\hline Vivo & 14.115 \\
\hline TIM & 12.789 \\
\hline Claro & 14.454 \\
\hline Oi & 13.684 \\
\hline Nextel & 3.195 \\
\hline CTBC & 521 \\
\hline Sercomtel & 50 \\
\hline Aeiou & 209 \\
\hline Total & 59.017 \\
\hline
\end{tabular}

Fonte: Anatel (dados referentes ao quarto trimestre de 2012).

Disponível em: <www.teleco.com.br/erb.asp>. Acesso em: 21 set. 2015).

As regiões Sudeste e Sul são as que mais concentram estações, o Nordeste fica numa posição intermediária e o Centro-Oeste e Norte detêm os menores números de estações. A presença de ERBs será, na concepção dos autores, diretamente relacionada ao universo populacional que abriga tais objetos. "Contudo, existe outros fatores que podem fazer o local ter mais estações, como relevo, edifícios, vegetação, entretanto o estudo econômico do local é que atualmente tem maior peso" (Silva; Toledo Junior, 2010, p.6).

Além disso, é preciso ressaltar que, do ponto de vista do uso do território, as operadoras para instalarem estações, antenas e outros aparatos vinculados à tecnologia celular precisam de diferentes tipos de autorização, retardando o processo de expansão das atividades corporativas no território. Isso ocorreu, recentemente, no atual quadro da telefonia celular 4G, obstaculizada pelas diferentes legislações municipais que dificultavam a expansão da malha celular nas cidades sedes da Copa do Mundo, 2014, no Brasil.

É claro que o governo também vem trabalhando no sentido de propor uma legislação padrão para o setor com a chamada "Lei Geral das Antenas", ainda em discussão no plenário. Por sua vez, com a aprovação desta lei, poderia haver no mercado maior flexibilização às empresas para operarem de modo a compartilharem infraestruturas, 
como ocorreu recentemente no caso da Claro e Vivo, no campo da tecnologia 4G de forma autorizada pela Anatel, bem como no sentido de facilitar a instalação de torres, estações com uma legislação única para todos os municípios e estados da federação.

Com isso, cumpre assinalar que as tecnologias da telefonia celular são cada vez mais expressivas e, a todo momento, novas formas de prover acesso e de se apropriar da comunicação são postas em curso e, para tanto, surgem novas siglas como $1 \mathrm{G}, 2 \mathrm{G}, 2,5 \mathrm{G}, 3 \mathrm{G}$, 4G e $5 \mathrm{G}$ para nomear tais evoluções da técnica, como demonstra o Quadro 7, que sintetiza e ilustra parte dessa argumentação.

Quadro 7-Gerações de sistemas celulares.

\begin{tabular}{|l|l|}
\hline Gerações & Caracterização \\
\hline $\mathbf{1 G}$ & Sistemas analógicos como o AMPS. \\
\hline $\mathbf{2 G}$ & $\begin{array}{l}\text { Sistemas digitais como o GSM, CDMA (IS-95-A) ou TDMA } \\
\text { IS-136. }\end{array}$ \\
\cline { 2 - 3 } & $\begin{array}{l}\text { O GSM e o CDMA possuem extensões que permitem a oferta de } \\
\text { serviços de dados por pacotes sem necessidade de estabelecimento } \\
\text { de uma conexão (conexão permanente) a taxas de até 144 kbps. As } \\
\text { principais são o GPRS e o EDGE para o GSM e o 1XRTT para o } \\
\text { CDMA. }\end{array}$ \\
\cline { 2 - 3 } & $\begin{array}{l}\text { Sistemas celulares que oferecem serviços de dados por pacotes } \\
\text { e taxas maiores que 256 kbps. Os principais sistemas são o } \\
\text { WCDMA/HSPA e o CDMA EVDO. (mais detalhes) }\end{array}$ \\
\hline $\mathbf{3}$ 3G & $\begin{array}{l}\text { O LTE Advanced e o WiMAX são as tecnologias aceitas como 4G } \\
\text { pela ITU. }\end{array}$ \\
\hline $\mathbf{4}$ & $\begin{array}{l}\text { Este sistema possui menor custo com maiores taxas de dados, ele } \\
\text { teve uma boa redução na latência, possui uma maior eficiência } \\
\text { espectral com largura de banda de até 100MHz. Ele foi projetado } \\
\text { para oferecer taxas de download de 100Mbps com o usuário em } \\
\text { movimento e 1Gbps com o usuário parado. Ele possui também } \\
\text { uma taxa de uplink de até 500Mbps. }\end{array}$ \\
\hline
\end{tabular}

Fonte: Teleco. Extraído de: <www.teleco.com.br/tecnocel.asp>. Acesso em: 21 set. 2015

Há, por conseguinte, diferentes ondas de implantação de determinadas tecnologias em certa parcela espacial do globo de acordo com os interesses, econômicos, políticos, sociais e culturais vigentes. Informações recentes, por exemplo, apontam que a União 
Europeia está investindo milhares de euros nas redes celulares de quinta geração, enquanto na Argentina, por exemplo, a meta é expandir a tecnologia $3 \mathrm{G}$ no território.

Já, no Brasil, a importância que a telefonia móvel assume é grande. Ela já superou a telefonia fixa em quantidade de aparelhos e acesso há um tempo e tem mudado a forma como a sociedade se comunica no país, seja ela com mensagens SMS, voz ou vídeo. Para o IBGE:

Em 1994, enquanto a telefonia fixa alcançava 86 usuários para cada mil habitantes, a telefonia celular só tinha cinco acessos; dez anos depois, a densidade de acessos a esse serviço entre mil habitantes alcançava 366 usuários, contra 279 da linha fixa, segundo a Agência Nacional de Telecomunicações (Anatel). Em 2008, a diferença era de 306 acessos à telefonia fixa contra 794 do serviço móvel para cada mil habitantes, o que corresponde a um aumento de $259 \%$ em quatro anos. Nesse mesmo ano, o país contava com mais de 150 milhões de acessos móveis. ${ }^{80}$

O ritmo de crescimento da telefonia celular tem sido alto. A competitividade entre as empresas, o barateamento de aparelhos e chips, aliados às estratégias de marketing em várias mídias, com as chamadas promocionais, têm impulsionado cada vez mais os números do setor, aumentando a receita líquida das empresas em operação no país.

Com isso, o fenômeno da privatização na área da telefonia não trouxe somente consigo a desestatização do serviço, mas a quebra do monopólio e a criação de uma agência reguladora em que a concessão do serviço de telefonia móvel:

[...] ocorre quando o governo decide, em 1996, que a Banda B seria colocada a venda primeiro e a Banda A só seria posta a venda em 1998. O edital definitivo da venda da Banda B é feito em julho

80 Disponível em: <www.ibge.gov.br/home/presidência/noticias/noticia_visualiza.php?id_noticia=1703\&id_pagina=1>. Acesso em: 21 set. 2015. 
de 1997, na qual o sistema foi dividido em dez áreas, organizadas em dois blocos, as áreas nobres e as áreas menos valorizadas. Em junho de 1998 o governo lança o edital da venda da Banda A. (Silva; Toledo Junior, 2010, p.2)

No começo, a privatização possibilitou às empresas a exploração de determinados "lotes espaciais" 81 no território brasileiro. $\mathrm{Ou}$ seja, as empresas arremataram a oportunidade de explorar uma dada porção do território nacional, evitando, com essa medida, em primeiro momento, a concorrência espacial direta. Já no caso da telefonia fixa, o Estado possibilitou, em um primeiro momento, praticamente o monopólio de determinadas empresas em função do lote arrematado, no leilão das telecomunicações no Brasil.

Naquele momento, "[...] O mercado tinha seu capital controlado por 20 grupos distribuídos em 10 regiões geográficas do território nacional (Anatel, 2007d, 2007e)" (Quintella; Costa, 2009, p.125). Isso, por outro lado, significou afirmar que uma operadora não poderia ocupar duas bandas em uma determinada região de concessão.

Tozi (2009) interpretou o assunto por meio da expressão "leilão dos fragmentos" para a compreensão do território como recurso e totalidade. Tal autor é enfático ao sublinhar que:

A regionalização do território criada para o leilão permitiu que as empresas, nacionais ou não, escolhessem, no território, a região mais adequada aos seus projetos, dada a desigualdade territorial brasileira, que cria escassas e abundantes combinações entre objetos e informações. As empresas internacionais têm presença expressiva (superior a 50\%) em onze das treze regiões leiloadas no dia 29 de julho de 1998. A única empresa com capital 100\% nacional é a Tele Norte Leste (posteriormente Telemar) que, no entanto

81 Essa expressão é utilizada para se referir à porção geográfica arrematada pela empresa no leilão. "Lote" porque se refere a uma fração do espaço, com caráter delimitado e função privada e "espacial” porque insere uma variável geográfica e física à exploração das empresas em suas estratégias de ganhos econômicos no uso corporativo do território. 
é uma empresa quase estatal, se tal classificação pudesse existir, pois o BNDES (Banco Nacional de Desenvolvimento Econômico e Social) detém 25\% das suas ações, os fundos de previdência do Banco do Brasil e Petrobrás outros 20\% e duas subsidiárias do Banco do Brasil, 10\% [...]. (Tozi, 2009, p.56)

Além disso, Tozi (2009) considerou que a consequência desse leilão tem ligação com a política que se relaciona com o cenário vivido naquele momento e, portanto:

Tal composição é também resultado daquilo que foi tornado público através da divulgação de conversas telefônicas gravadas ("escândalo do grampo"), em que o presidente Fernando Henrique Cardoso, o presidente do BNDES, André Lara Resende e o Ministro das Comunicações, Luiz Carlos Mendonça de Barros revelavam acordos com empresários cuja intenção inicial era que o consórcio comprador da Telemar tivesse arrematado, no leilão, a Telesp. Há aspectos das privatizações nunca esclarecidos, que envolvem ainda, além dessa negociata mencionada, os preços de venda, definidos por consultorias internacionais, e os ágios praticados no negócio, mostrando que ou as empresas foram mal avaliadas ou os investidores supervalorizaram seus preços, como também analisa Biondi (2001). Em qualquer dos casos, há uma deliberação das consultorias (que se pautam no "mercado") assumida pelo governo (Tozi, 2009, p.56-57).

Agora, tendo como referência Quintela e Costa (2009), pode-se afirmar, grosso modo, que esse comando espacial no uso corporativo do território só foi quebrado a partir de 2001, com a introdução de novas regras para o setor no qual a Anatel:

[...] realizou a venda de novas licenças para a exploração da telefonia móvel no país, introduzindo as chamadas bandas C, D e E, por meio de novas licitações e de um novo conjunto de normas, conformando um novo aparato, agora denominado Serviço Móvel Pessoal 
(SMP). Desde então, alguns importantes fatos públicos puderam ser observados no setor como: a introdução da tecnologia GSM (global system mobile communications); o aumento do número de operadoras móveis, competindo em uma mesma região geográfica; novos planos de serviços que incluíam, além das chamadas para celular, chamadas de longa distância nacional ou serviços de telefonia fixa, móvel e acesso à internet em um único pacote; e a participação de capital dos grupos controladores das operadoras móveis nas operadoras da telefonia fixa e vice-versa [...]. (Quintella; Costa, 2009, p.125)

Com isso, a sigla Serviço Móvel Celular (SMC) foi trocada para Serviço Móvel Pessoal (SMP), no qual o indivíduo, por meio de roaming, poderia se deslocar espacialmente sem ficar refém da sua célula de conexão. A partir desse movimento, gerou-se a possibilidade da mobilidade pessoal de dados e voz através da telefonia celular, mas também a concorrência de várias empresas em uma dada fração do espaço.

Não há o domínio único e exclusivo de uma determinada operadora em certa porção espacial, mas há a competição entre as empresas que participam desse mercado, mesmo que em distintas faixas, subfaixas e bandas de frequência, em uma dada região ou área.

Além disso, é possível visualizar nas práticas espaciais que as empresas do segmento vêm cada vez mais diversificando suas estratégias. Consequentemente, nos últimos anos tem havido um fenômeno de integração da telefonia fixa à celular, fazendo com que determinadas companhias, que antes operavam com nomes distintos e capitais variados, se integrem a uma mesma marca, sobretudo, se analisado esse movimento a partir de 2011, como ocorreu com a Telefônica e Vivo, Telemar e Oi.

Segundo o jornal Folha de S.Paulo, "Uma mudança na legislação em 2011 permitiu às teles reunirem em um único CNPJ empresas do mesmo grupo. Antes, isso era proibido." ${ }^{22}$ Ainda segundo a mesma

82 Trecho extraído do jornal Folha de S.Paulo, na versão eletrônica. Disponível em: $<$ www1.folha.uol.com.br/colunas/mercadoaberto/2013/05/1283313-fusao- 
fonte, fusões geram economia porque determinados impostos não são mais pagos quando se trata de um mesmo grupo empresarial.

Por se tratar de uma nova corporação que entra no mercado, esse tipo de negócio não precisa passar pela análise do Cade (Conselho Administrativo de Defesa Econômica), cabendo à Anatel decidir sobre cada situação no mercado das telecomunicações. A Anatel, dessa maneira, para aprovar uma fusão poderá exigir da empresa resultante da fusão redução de preços na oferta de determinado produto, a exemplo da telefonia fixa com a diminuição da tarifa por minuto cobrado pela operadora.

Entretanto, é preciso ter em vista que essas ações não ficaram restritas a esses segmentos e foram levadas a cabo no campo da TV por assinatura no Brasil, com a política de fortalecimento de marcas e o oferecimento de produtos por pacotes (TV paga, banda larga celular).

Assim, é possível estabelecer o número de municípios com atendimento celular por operadora com base nos dados da Anatel (vide Tabela 6). A Vivo é a operadora com maior número de municípios atendidos, entretanto, a Claro é a que possui maior porcentagem de população atendida, visto que os municípios apresentam diferentes gradações populacionais.

Tabela 6-Número de municípios com atendimento celular por operadora segundo a Anatel (Abril de 2013).

\begin{tabular}{c|c|c}
\hline Operadora & Municípios atendidos & População atendida \\
\hline Vivo & 3.754 & $91,10 \%$ \\
\hline Claro & 3.634 & $91,30 \%$ \\
\hline Tim & 3.357 & $90,80 \%$ \\
\hline Oi & 3.316 & $87,90 \%$ \\
\hline CTBC & 99 & $1,90 \%$ \\
\hline Aeiou & 5 & $7,60 \%$ \\
\hline Sercomtel & 2 & $0,30 \%$ \\
\hline
\end{tabular}

Fonte: Anatel. Dados disponíveis em: <www.teleco.com.br/cobertura.asp>. Acesso em: 21 set. 2015.

-entre-telefonica-e-vivo-sera-decidida-hoje.shtml>. Acesso em: 21 set. 2015. 
Já, no que tange ao número de celulares por operadora e ao Market Share das companhias para o terceiro trimestre de 2013, verifica-se que a Vivo possuía o maior número de celulares (Tabela 7) entre as operadoras listadas em milhares (75.998) e o maior Market Share com 28,78\%, seguida por Tim, Claro e Oi.

Tabela 7 - Distribuição do número de celulares por operadora e Market Share (terceiro trimestre de 2013). ${ }^{83}$

\begin{tabular}{l|l|l|l|l}
\hline Posição & \multirow{2}{*}{ Operadora } & Controlador & Celulares & Market \\
\cline { 3 - 5 } & & & (Milhares) & Share \\
\hline $1^{\mathrm{a}}$ & Vivo & Telefônica & 75.988 & $28,78 \%$ \\
\hline $2^{\mathrm{a}}$ & TIM & Telecom Itália & 71.232 & $26,98 \%$ \\
\hline $3^{\mathrm{a}}$ & Claro & América Móvil & 66.308 & $25,11 \%$ \\
\hline $4^{\mathrm{a}}$ & \multirow{2}{*}{ Oi } & $\begin{array}{l}\text { AG, LaFonte, BNDES, } \\
\text { Fundos }\end{array}$ & 49.494 & $18,74 \%$ \\
\cline { 3 - 3 } & & e Portugal Telecom & & \\
\hline $5^{\mathrm{a}}$ & CTBC & CTBC & 840 & $0,32 \%$ \\
\hline $6^{\mathrm{a}}$ & Sercomtel & Prefeitura Londrina/Copel & 69 & $0,03 \%$ \\
\hline $7^{\mathrm{a}}$ & Nextel & NII Nextel & 80 & $0,03 \%$ \\
\hline $8^{\mathrm{a}}$ & Outras & $\begin{array}{l}\text { Porto Seguro e Datora } \\
\text { (MVNO) }\end{array}$ & 42 & $0,02 \%$ \\
\hline
\end{tabular}

Fonte: Anatel. Extraído de: <www.teleco.com.br/opcelular.asp>. Acesso em: 21 set. 2015.

Portanto, é tendo como base esse panorama de transformações na telefonia celular que se desenvolverá, nas linhas seguintes, a análise do setor por meio da análise das principais empresas no uso corporativo do território.

83 Nessa tabela até poderia ser acrescido o valor total de celulares pela população, mas não se encontram dados de população em valor estimado por trimestre no Brasil, o que poderia tornar falsa tal proporção. 


\section{Vivo S.A.}

A Vivo é o resultado da união de grandes companhias de telefonia móvel, ${ }^{84}$ no quadro posterior à privatização do setor no Brasil. Foi comandada pela Telefónica España e Portugal Telecom, sendo a Telefónica, atualmente, o grupo que dirige a marca, visto que a Portugal Telecom vendeu sua posição para esta última em $2010^{85} \mathrm{e}$ passou a atuar pela $\mathrm{Oi}$, com o anúncio de uma fusão em outubro de 2013 com o surgimento da CorpCo.

No campo da telefonia fixa, operava como Telefônica no Estado de São Paulo, possuindo uma ampla gama de clientes, sendo a responsável por adquirir a antiga Telesp (Telecomunicações de São Paulo), antes vinculada ao grupo Telebrás, no momento anterior à privatização do setor na década de 1990. Além disso, com o passar do tempo, incorporou outras empresas locais do segmento, aumentando, por conseguinte, sua presença territorial e econômica, como ocorreu com a Ceterp (Centrais Telefônicas de Ribeirão Preto S.A.).

Em 2012, a companhia passou a atuar somente com a marca Vivo. A Vivo opera na prestação de serviços na telefonia fixa e móvel, banda larga, over fiber (ultra banda larga), TI, TV paga e dados. Em São Paulo oferece o serviço de telefonia fixa e em todas as unidades da federação o serviço de telefonia celular. Nesse sentido, a empresa detém uma posição de liderança no Brasil, sendo relevante frisar que:

84 Essa informação é baseada em Tozzi (2009, p.56). Para o sítio Teleco, as prestadoras que deram origem a Vivo foram a "[...] Telesp Celular Participações S.A., inclui Global Telecom; Tele Centro Oeste Participações S.A., inclui NBT; Tele Leste Celular Participações S.A.; Tele Sudeste Celular Participações S.A. e Celular CRT Participações S.A." (Disponível em: <http://www. teleco.com.br/operadoras/vivo.asp>. Acesso em: 16 mai. 2013.

85 Referenciado em Teleco. Disponível em: <www.teleco.com.br/operadoras/ ptelecom.asp>. Acesso em: 21 set. 2015. 
A empresa está presente em mais de 3,7 mil cidades, mais de 2,9 mil delas com acesso à rede $3 \mathrm{G}$ - mais do que o total dos municípios atendidos pelas demais operadoras. O Brasil, onde atua desde 1998, é a maior operação mundial da Telefônica em número de clientes. ${ }^{86}$

Com isso, quando se passa para a análise do grupo Telefónica verifica-se que este é:

[...] um dos maiores conglomerados de comunicação do mundo, com presença em 25 países 313,8 milhões de acessos, 286 mil empregados e receitas de 62,8 bilhões de euros (2011). Os investimentos previstos para o Brasil no período 2011-2014 totalizam R\$ 24,3 bilhões. As principais empresas são Telefônica Brasil (Telefônica Vivo) e Terra (provedor e portal de internet). ${ }^{87}$

No mundo, a Telefónica atua na África, América Latina e Europa, em países como Espanha, Inglaterra, Alemanha, Irlanda, República Tcheca e Eslováquia. No Chile e Argentina, ocupa posição de destaque entre as empresas do segmento. No Brasil, as empresas que compõem o grupo são a TGestiona, vinculada à soluções de logística e gestão de terceiros, Terra como provedor e portal de conteúdo, Telefônica SP e Vivo.

No quarto trimestre de 2012, o Market Share da companhia era de $29,1 \%$ e no mesmo período a penetração no mercado de $132,7 \%$ com tráfego total de 29.393 (milhões de minutos). O total de acessos móveis correspondia à cifra em milhares de 76.137 e o fixo a $14.978 .^{88}$

86 Trecho extraído de: <www.telefonica.com.br/institucional/sobre-a-telefonica/quem-somos>. Acesso em: 21 set. 2015.

87 Trecho extraído de: <www.telefonica.com.br/institucional/sobre-a-telefonica/quem-somos>. Acesso em: 21 set. 2015.

88 Parágrafo construído com base na leitura dos dados fornecidos pela Vivo. Disponível em: <http://telefonica.mediagroup.com.br/pt/Info_Mercado/ Desempenho_Operacional.aspx>. Acesso em: 21 set. 2015. 
Para o portal de notícias da G1, vinculado a Globo, o lucro líquido da Telefônica/Vivo, em 2012, “[...] foi de R \$ 4,452 bilhões, aumento de 2,1\% em relação a 2011. O lucro atribuído aos acionistas controladores, base para o cálculo de dividendos, somou R \$ 4,453 bilhões, alta de 2,25\%" (Disponível em: <http://g1.globo.com/ economia/negocios/noticia/2013/02/telefonicavivo-tem-lucro-de-r-445-bilhoes-em-2012.html>. Acesso em: 21 set. 2015).

Além disso, vale ressaltar que a Vivo tem se mantido na liderança do mercado de telefonia móvel no país, possuindo o maior Market Share, bem como o de celulares e número de acessos.

No final de setembro de 2013, foi anunciado, também pelo grupo Telefónica España, que a companhia passará a assumir o controle da Telco, que é a principal acionista da Telecom Itália e que por sua vez comanda a Tim no Brasil. Assim:

[...] a Telefónica aumentará sua participação na Telco de 46\% para $66 \%$ inicialmente, via um aumento de capital de 324 milhões de euros direcionados a pagar dívidas da empresa, disseram os sócios da Telco em comunicado. A holding controla a Telecom Italia com uma fatia de 22,4\% do capital social. A Assicurazioni Generali, com $31 \%$, a Intesa Sanpaolo, com 11,6\%, e a Mediobanca, também com 11,6\%, completam a estrutura acionária da Telco. Recentemente, os acionistas da Telco começaram a discutir uma mudança na estrutura acionária. Em 28 de setembro expira o acordo que os mantêm unidos. ${ }^{89}$

Porém, tal movimento não passará despercebido pelas instâncias reguladoras no Brasil, a exemplo do Cade (Conselho Administrativo de Defesa Econômica) e da Anatel. A solução para a Tim seria, portanto, no futuro, a sua venda para outras companhias que não operam no mercado de telefonia celular no país, como a inglesa

89 Disponível em: <http://veja.abril.com.br/noticia/economia/telefonica-torna-se-socia-majoritaria-da-controladora-da-tim>. Acesso em: 21 set. 2015. 
Vodafone, ou mesmo a sua divisão e venda aos grandes grupos em operação nacionalmente como a Oi/CorpCo e Claro.

Além disso, Tim e Vivo detêm importante participação no mercado de telefonia celular no Brasil, o que elevaria a concentração do mercado, disputado majoritariamente por poucas corporações no modelo oligopolista. Sendo assim:

Levando em conta o número de linhas por operadora por estado, mais da metade do país teria uma concentração superior a 50\%, sendo que destes, quatro apresentariam uma fatia de mais de $75 \%$ dominada por TIM e Vivo. (Disponível em: <http://veja.abril. com.br/noticia/economia/acordo-entre-telefonica-e-tim-escancara-concentracao-do-setor-de-telefonia-no-brasil>. Acesso em: 8 out. 2013)

Tal acordo, nesse sentido, aumentaria ainda mais o poder de ação do Grupo Telefónica e transformaria o setor brasileiro de telecomunicações com a vitória de uma grande companhia sobre as demais corporações que operam no uso do território. Ademais, é tendo em vista esse quadro que a Telefónica tem aumentado, cada vez mais, sua participação no mercado, sobretudo, no período recente em que a companhia anunciou a compra da GVT, pertencente ao grupo Vivendi, por 7 bilhões de euros..$^{90}$

\section{Tim Participações S.A. ${ }^{91}$}

A Tim iniciou suas atividades no Brasil em 1998, após a privatização do setor de telefonia móvel e fixa no país como holding, ofertando serviços por meio das subsidiárias Intelig Telecomunicações

90 Informação disponível no sítio do Jornal Folha de S.Paulo em: <www1.folha. uol.com.br/mercado/2014/09/1518379-telefonica-fecha-acordo-de-7-bide-euros-para-comprar-gvt.shtml>. Acesso em: 21 set. 2015.

91 O item tem como base fundante a leitura da Tim a partir do sítio: <http:// tim.riweb.com.br/show.aspx?idCanal=9ROHtD3EH+7QuGpf7dfD3g > . Acesso em: 21 set. 2015. 
Ltda. e Tim Celular S. A. A companhia presta serviços na telefonia móvel e fixa, transmissão de dados, entre outros.

A Tim Participações é controlada, por sua vez, pela Tim Brasil Serviços e Participações S.A., que é uma subsidiária do grupo Telecom Itália que tem como controladora a Telco da Telefónica España. A Telecom Itália, ${ }^{92}$ por sua vez, tem como mercados estratégicos Itália, Brasil e Argentina. Além disso, o grupo é ativo na Europa, América do Norte, Ásia e África por meio da Telecom Italia Sparkle, Lan Nautilus e Med Nautilus.

A Tim foi a primeira a operar em todos estados brasileiros a partir de 2002, sendo pioneira na oferta de produtos como o Black Berry. Atingindo 95\% da população urbana do país, a empresa está presente em 3.383 cidades, detendo acordos para operar roaming internacional em mais de 208 países $^{93}$.

A Tim Participações é controlada pela TIM Brasil Serviços e Participações S.A., sendo uma subsidiária da Telecom Itália. Já a Intelig foi adquirida pela Tim no final de 2009 e processou sua integração em 2010. Para o jornal O Estado de S. Paulo:

A compra foi fechada por meio de uma operação de troca de ações. Pelo acordo, a TIM assume o controle integral da Intelig, e a Docas, por meio da empresa JVCO Participações Ltda., fica com 6,15\% das ações ordinárias e 6,15\% das preferenciais da TIM Participações. (Disponível em: <www.estadao.com.br/noticias/ impresso,tim-fecha-acordo-para-compra-da-intelig,356127,0. htm>. Acesso em: 21 set. 2015)

O jornal, ainda em questão, afirmou que a Doca Investimentos comprou a Intelig do consórcio composto pela National Grid, Sprint Nextel e France Telecom. A aquisição da Intelig possibilitou

92 O parágrafo foi referenciado com base na leitura do sítio da Telecom Itália. Disponível em: <http://www.telecomitalia.com/tit/it/about-us/geographical-dispersion.html>. Acesso em: 21 set. 2015.

93 O parágrafo tem como referência o sítio: <http://tim.riweb.com.br/show. aspx? idCanal=9ROHtD3EH+7QuGpf7dfD3g > . Acesso em: 21 set. 2015. 
à Tim aperfeiçoar custos, operar em telefonia fixa e banda larga, dando à empresa maior poder de oferta de serviços, bem como tornando mais rápido o processo de oferta de uma rede $3 \mathrm{G}$.

Além disso, a Tim adquiriu a Eletropaulo Telecomunicações Ltda. em 2011 e, com isso:

[... assinou com a Companhia Brasiliana de Energia e a AES Elpa contrato para compra da totalidade das quotas da Eletropaulo Telecomunicações (AES Atimus SP) e das ações da AES Communications Rio de Janeiro (AES Atimus RJ). Estas duas empresas são controladas, respectivamente, pela Brasiliana e por sua subsidiária AES Elpa. A Brasiliana é a holding que controla a AES Eletropaulo e a geradora AES Tietê. O valor total da aquisição será de R \$ 1,6 bilhão. (jornal $O$ Estado de S. Paulo. ${ }^{94}$

Depois disso, a empresa passou a compor a Tim Fiber SP e a Tim Fiber RJ, somando a estrutura da Tim uma grande rede de fibra óptica.

Osdados operacionais consolidados daempresa demonstraram, ${ }^{95}$ para 2012, 3.383 municípios atendidos pela Tim no Brasil, uma penetração estimada de 132,8\%, Market Share de 26,9\% e 11.650 empregados, sendo que para o acumulado do ano de 2012:

[... ] a TIM registrou lucro líquido de $\mathrm{R} \$ 1,449$ bilhão, aumento de 13,4\% na comparação com 2011. Segundo o balanço, incluindo os $\mathrm{R}$ \$ 42,1 milhões dos eventos não recorrentes, mais $\mathrm{R}$ 9,1 milhões

94 Disponível em: <http://economia.estadao.com.br/noticias/negocios-servicos,tim-compra-aes-atimus-por-r-16-bilhao-,75119,0.htm >. Acesso em: 21 set. 2015.

95 Os dados foram obtidos por meio do sítio da Tim - Relações com investidores. Disponível em: <http://tim.riweb.com.br/show.aspx?idCanal=9ROHtD3EH+7QuGpf7dfD3g>. Acesso em: 21 set. 2015. 
em ajustes monetários, o lucro líquido ajustado em 2012 totalizou $\mathrm{R} \$ 1,5$ bilhão, o que corresponde a uma alta de $17,4 \% .{ }^{96}$

Com isso, no período recente, a Tim tem se mantido na segunda posição em termos de Market Share no país, no segmento de telefonia celular. A empresa, dessa forma, adota uma estratégia de oferecer pequenos preços para a realização de chamadas, visando alcançar o maior número de clientes possíveis, investindo também em marketing por meio de campanhas televisivas e em outras mídias, bem como em infraestrutura.

\section{Claro S.A.}

Em 2003, a Claro iniciou suas atividades no Brasil com o resultado da união de operadoras oriundas do processo inicial de privatização do setor, sendo elas: Americel (atuante em parte do Norte e no Centro-Oeste), Tess (litoral e interior de São Paulo), BCP Nordeste, BCP SP e Claro Digital (Rio Grande do Sul).

No momento, a Claro tem como grupo controlador a América Movil, que é um dos maiores do mundo, atuando em 18 países da América, com mais de duzentos e sessenta e três milhões de celulares. Na América do Norte, opera nos Estados Unidos e México; em vários países da América Central e Caribe; e na América do Sul na Argentina, Brasil, Chile, Colômbia, Equador, Paraguai, Peru e Uruguai. ${ }^{97}$

Além disso, o grupo oferta em diversos países a possibilidade de roaming internacional com serviços de voz e de dados, por exemplo. No Brasil, o grupo América Móvil opera com a Net, Embratel e Claro.

96 Disponível em: <http://g1.globo.com/economia/negocios/noticia/ 2013/02/tim-registra-lucro-de-r-1449-bilhao-em-2012-alta-de-134.html>. Acesso em: 21 set. 2015.

97 Parágrafo constituído com base na leitura do sítio da América Móvil, no item subsidiárias e afiliadas. Disponível em: <www.americamovil.com/amx/ about/footprint? $\mathrm{p}=1>$. Acesso em: 21 set. 2015. 
Em 2011, o grupo América Móvil lançou no país, por meio de suas operadoras, um serviço em conjunto, sem que isso se traduzisse numa fusão entre as empresas. Sobre o assunto, o portal G1 esclareceu que os serviços prestados de modo integrado se referiam ao pacote Combo Multi que envolve: "[...] TV por assinatura, vídeos sob demanda, banda larga fixa, $w i-f i$ (residencial e em locais públicos), internet $3 \mathrm{G}$ (com modem e pelo smartphone) e telefone fixo". ${ }^{98}$

Assim, é preciso ressaltar que os serviços da Claro reúnem telefonia celular e fixa, TV paga e internet em mais de 3.600 municípios, conforme informação divulgada no sítio $^{99}$ da empresa, sendo que a telefonia fixa e a TV por assinatura antes oferecidas pela Embratel operam sob a marca Claro desde 2012.

Em 2013, a empresa foi a primeira entre as companhias de telecomunicação a ofertar tecnologia 4G no Brasil. Sobre o desempenho financeiro da empresa a Revista Exame destacou que:

O relatório, que representa somente as finanças da operadora (a controladora América Móvil mescla os dados referentes da Claro com as outras controladas no País - NET, Embratel e Star One), mostrou um prejuízo líquido consolidado de $\mathrm{R}$ \$ 880,496 milhões, contra R\$330,146 milhões em 2011. Sem o custo de serviços prestados e mercadorias vendidas, o lucro bruto da operadora chegou a $\mathrm{R} \$ 3,573$ bilhões, crescimento de 10,06\%. ${ }^{100}$

Ao mesmo tempo, segundo o Teleco, ${ }^{101}$ em termos de Market Share para 2012 a Claro possuía 24,92\% do total das operadoras

98 Extraídode:<http://g1.globo.com/tecnologia/noticia/2011/10/net-claro-e-embratel-se-unem-para-lancar-servico-de-telecomunicacoes.html>. Acesso em: 21 set. 2015.

99 Para maiores detalhamentos, consulte o sítio: <www.claro.com.br/institucional/conheca-claro/regiao/ddd18/SP-OUT/tv-2/>. Acesso em: 21 set. 2015.

100 Disponível em: <http://exame.abril.com.br/negocios/noticias/claro-s-a-registrou-prejuizo-liquido-de-r-880-milhoes-em-2>. Acesso em: 21 set. 2015.

101 Dados disponíveis em: <www.teleco.com.br/mshare.asp>. Acesso em: 29 mai. 2013. 
e 65.238 em milhares de celulares para o mesmo período, ficando muito próxima ao desempenho da Tim, que é a segunda colocada no momento.

Nesse sentido, a Claro se consolida como grande empresa do setor de telecomunicações e se somando às estratégias da América Móvil para a América Latina.

\section{Oi S.A. - CorpCo}

A Oi se traduz em uma empresa que opera no serviço móvel celular no contexto pós-privatização do setor. Pode-se afirmar, por outro lado, que a participação de capital brasileiro na companhia é bastante importante. A Oi teve como base estrutural dois grandes grupos de telecomunicação no país: a Telemar e a Brasil Telecom.

A Brasil Telecom unificou, em 2000, nove operadoras do segmento sob a mesma marca, além de compor sociedade no IG. No ano seguinte, por sua vez, a Telemar integrou 16 operadoras do segmento do país. Já em 2002 a Telemar criava a Oi, fazendo dessa em 2007 sua marca única e em 2009 obtendo o controle da Brasil Telecom e, por conseguinte, operando em todo território nacional.

Com isso, em 2012, foi finalizado o processo de reorganização societária da empresa, iniciado em 2011, envolvendo também a aliança entre Oi e Portugal Telecom, com aquisição de participação mútua entre as empresas. Nesse momento, pode-se destacar, portanto, que:

A Oi é uma concessionária responsável pelo Serviço Telefônico Fixo Comutado ("STFC") nas Regiões I e II do Plano Geral de Outorgas ("PGO"), que abrange todos os estados da federação exceto São Paulo, além do Distrito Federal. Os contratos de concessão tem vigência até 31 de dezembro de 2025.

Além disso, a Oi possui autorização da ANATEL para a prestação de serviços de Telefonia Móvel ("SMP") em todo o país. Completam ainda o portfolio da companhia os serviços de rede de 
transporte e Backbone internacional, transmissão de dados e TV por assinatura. ${ }^{102}$

Para o Teleco, ${ }^{103}$ o Market Share da companhia em 2012 era de $18,81 \%$ e 49.238 em milhares de celulares para o período. No relatório anual de sustentabilidade da companhia foi destacado que a Oi possuía:

[...] 13.224 colaboradores, 549 estagiários e 82 aprendizes técnicos. Todos os colaboradores têm contrato de período integral. A Oi possui também 141.384 trabalhadores terceirizados, distribuídos em atividades de call center, administração patrimonial, canais de vendas e operações de manutenção, entre outras. ${ }^{104}$

Para a Oi, ${ }^{105}$ em 2012, eram 74,3 milhões de clientes, sendo 46,3 milhões de clientes na telefonia celular (38 milhões na modalidade pré-paga e 5,3 milhões no serviço pós-pago) e 19,1 milhões de usuários em telefonia fixa, banda larga e TV paga.

Segundo a Exame, a Oi “[...] deverá ajustar o lucro líquido do ano passado de $\mathrm{R}$ \$ 837 milhões para R \$ 1,7 bilhão”. ${ }^{106}$ Isso se tratando de 2012, depois que a empresa recebeu o aval da Comissão de Valores Mobiliários para proferir tal alteração em razão da incorporação da Brasil Telecom, o que envolveria, por conseguinte, um novo tratamento contábil.

Além disso, é válido frisar que o acordo firmado entre a Oi e a Portugal Telecom, para fusão com a denominação de CorpCo, ele-

102 Disponível em: <http://ri.oi.com.br/oi2012/web/conteudo_pt.asp?idioma $=0 \&$ conta $=28 \&$ tipo $=43302>$. Acesso em: 21 set. 2015 .

103 Dados disponíveis em: <www.teleco.com.br/mshare.asp>. Acesso em: 21 set. 2015.

104 Disponível em: <http://relatorioanual2011.oi.com.br/desempenho-socioambiental/relacao-com-colaboradores/. Acesso em: 21 set. 2015.

105 Dados disponíveis em: <http://ri.oi.com.br/oi2012/web/conteudo_pt.asp? idioma $=0 \&$ conta $=28 \&$ tipo $=43302>$. Acesso em: 21 set. 2015.

106 Disponível em: <http://exame.abril.com.br/negocios/noticias/decisaofavoravel-da-cvm-eleva-lucro-da-oi-em-2012>. Acesso em: 21 set. 2015. 
vará ainda mais a sua atuação em territórios estrangeiros, a exemplo da Europa, África e Ásia. Isso foi positivo para a companhia, à medida que injeta mais recursos e investimentos oriundos da Portugal Telecom, bem como do governo brasileiro por meio do BNDES e dos fundos estatais que compõem a estrutura societária da companhia. 


\section{4 \\ EXPRESSÃO GEOGRÁFICA DO USO \\ CORPORATIVO DO TERRITÓRIO PELAS \\ EMPRESAS DE TELECOMUNICAÇÃO}

\section{Dos "lotes espaciais" ao uso nacional do território}

A análise das telecomunicações no Brasil revela-se em grande complexidade, no momento atual, em que as corporações ampliam o seu poder de ação no uso do território nacional de modo integrado, disponibilizando diversos serviços em conjunto aos consumidores. O mercado é concorrido e o cenário de disputa comercial é dividido entre poucos competidores (especialmente nos segmentos de televisão paga, telefonia celular e fixa), mas que apresentam altos lucros a cada ano, com investimentos concentrados, especialmente nos grandes centros urbanos brasileiros, adensados em termos de população e renda.

No começo da privatização do setor de telecomunicações no Brasil, poderia se escrever, no caso da telefonia celular e fixa, que as empresas privadas agiam no território ainda de forma muito restrita e fragmentada, em termos espaciais. Isso porque o modelo de leilão restringia que os grupos consorciados operassem em mais de uma área arrematada. Isso dividia o território basicamente em "lotes espaciais" de atuação das companhias, com exceção da Embratel, 
que operava nacionalmente, e da Intelig (empresa espelho concorrente), enquanto a Telefónica, por exemplo, atuava no Estado de São Paulo, na estrutura do leilão, embora tivesse arrematado anteriormente operação no Rio Grande do Sul.

Com isso, enquanto a ideia de "lote" se refere ao caráter de função privada de exploração do negócio, delimitado a um estado ou porção territorial, arbitrariamente conformado, em razão de particularidades econômicas e potencialidades de consumo, o termo espacial insere o componente geográfico de atuação das companhias no uso do território.

Além disso, ficava assegurada a cada grupo consorciado uma fatia exclusiva no mercado e de caráter praticamente monopólico. Embora haja de se ressaltar que a inserção das empresas espelho, no cenário de competição, fazia pelo menos em termos de "papel/lei" uma competição no formato de duopólio, o que não era percebido na prática pelos consumidores.

Nos anos 2000 e no início da década de 2010, houve uma maior liberalização para atuação no mercado por parte das companhias, o que acabou por transformar o uso do território em uma arena para disputa entre quatro grandes empresas: Vivo, Claro e Tim, decorrentes da ação do capital internacional, e do capital nacional a Oi, o que se revelou, por outro lado, na formação de um oligopólio concentrado, no plano nacional.

Sobre o período destacado, o Ipea (Instituto de Pesquisa Econômica Aplicada), em texto de discussão sobre a liberalização dos serviços de telecomunicações, produziu uma síntese das transformações societárias dessas empresas ao expor que:

A Portugal Telecom e a Telefónica de España, controladoras de diferentes empresas nas bandas A e B, se associaram na formação do grupo Vivo. A Telecom Américas, controlada pela América Móvil, passou a operar com o nome Claro. A Telecom Itália lançou a marca TIM. A Telemar e a Brasil Telecom, operadoras de telefonia fixa nas regiões I e II, adquiriram novas autorizações para 
exploração de telefonia móvel em suas regiões, surgindo a Oi e a Brasil Telecom Celular [...] (Miranda et al., 2011, p.19)

Além disso, tais companhias, depois de assumidas as metas de universalização, saem do plano de atuação meramente da telefonia fixa e celular para marcar presença fortemente nos mercados de televisão paga e internet (banda larga fixa e móvel). Em 2001, o serviço móvel celular foi transformado no serviço móvel pessoal, ampliando o poder de atuação das companhias, conectando o país gradativamente, em termos informacionais e corporativos.

Também, é a partir da leitura desse contexto que se pode escrever em termos práticos de um uso nacional do território pelas operadoras de telecomunicação, em oposição ao sentido dos lotes espaciais do passado. De 1996 a 2005, as empresas aplicaram no setor 129,2 bilhões de reais no país, atingindo o maior pico de investimento em 2001, quando as companhias se preparavam para cumprir com as metas de universalização (Loural; Leal, 2010, p.13).

Nesse caso, não se deve realizar uma análise das telecomunicações como um setor isolado dos demais da economia, mas com uma interpretação que seja capaz de relacionar a produção de conteúdos, as tecnologias da informação, as novas formas de consumo, associadas ao comércio eletrônico e por extensão a "informacionalização da economia", sendo que no cenário brasileiro verifica-se que:

Os setores de Telecom e de Tecnologia da Informação tiveram forte impacto na receita de Serviços no Brasil, segundo a Pesquisa Anual de Serviços - PAS - com dados de 2011, divulgada nesta quarta-feira, 28/08, pelo IBGE. Segundo o levantamento, os serviços de informação e comunicação - que englobam as atividades ligadas à criação, disseminação, transmissão e armazenamento de produtos com conteúdo informativo - têm empresas que apresentam, em média, produtividade e salários elevados. ${ }^{1}$

1 Disponível em: <http://convergenciadigital.uol.com.br/cgi/cgilua.exe/sys/ start.htm? infoid=34693\&sid=5\#.Uuk_fhBdVu4>. Acesso em: 21 set. 2015. 
E, com isso:

Em 2011, segundo o IBGE, destacam-se as atividades de telecomunicações, que, em geral, são de grande porte e intensivas em capital, representando 4,8\% do total (4,3 mil) e sendo responsáveis pela maior receita operacional líquida ( $\mathrm{R}$ \$142,4 bilhões ou 54,9\%), maior média de pessoas ocupadas por empresa (42, ante a média do segmento de 10) e produtividade ( $\mathrm{R} \$ 335,4$ mil). Os serviços de tecnologia da informação obtiveram a maior participação no número de empresas (63,6\%, 57,0 mil), de pessoal ocupado (49,6\%, 442,2 mil) e de massa salarial (52,9\%, R\$ 18,4 bilhões), apresentando, também, o maior salário médio, 6,0 salários mínimos. ${ }^{2}$

Deste modo, observa-se especialmente a concentração de capital e de poder dos grupos, no cenário em que os capitais mais débeis são absorvidos, ou mesmo quando se dá o processo de fusão e aquisição entre operadoras, que até então tinham razões sociais distintas, no sentido de criar uma nova companhia ou até fortalecer uma marca já existente, movimentando altas somas de capitais, periodicamente.

As estratégias das companhias têm, portanto, experimentado uma diversificação na qual há um número cada vez menor de companhias atuando no mercado, participando de um processo de concentração e, ao mesmo tempo, centralização dos serviços.

O movimento estratégico das companhias tem mirado em diversos sentidos e ações práticas. Com isso, são firmadas alianças entre o capital nacional e internacional para operação, em diversos momentos, na história das telecomunicações no Brasil, mas especialmente no período de privatização e pós-privatização. Embora haja de se fazer uma ressalva, que no segmento de televisão por assinatura já havia uma simbiose de capitais e, mais recentemente, o capital estrangeiro passa a ter o controle desse mercado de ope-

2 Disponível em: <http://convergenciadigital.uol.com.br/cgi/cgilua.exe/sys/ start.htm? infoid=34693\&sid=5\#.Uuk_fhBdVu4>. Acesso em: 21 set. 2015. 
radoras, dividindo-o basicamente em um duopólio (Claro/Net - América Móvil - de um lado e de outro Sky - DirectTV Group). Enquanto o setor de internet também contou desde o início de sua abertura na década de 1990 com investimento privado, embora em período anterior tivesse contado com maciço aporte de capital estatal, provenientes, notadamente, de agências de fomento à pesquisa como a Fapesp e o CNPq e, nesse sentido, é preciso destacar que:

[...] las nuevas tecnologías impulsaron decisivamente la mundialización de todas las formas del ciclo del capital (capital-mercancía, capital-dinero, capital-productivo) estableciendo los mecanismos básicos para la progresiva transnacionalización de la economía y de la sociedad a escala planetaria (Michalet, 1985); con ello, se afirmó definitivamente el papel del capital multinacional como factor de la dinámica de acumulación. (Mattos, 1992, p.149)

Assim, os sócios estrangeiros têm investido cada vez mais e controlado, por sua vez, as empresas que antes tinham uma importante participação do capital nacional nas telecomunicações. Os serviços de telefonia celular, internet, televisão paga e telefonia fixa caminham no sentido de as operadoras ofertarem todos os serviços em conjunto. Com isso, os clientes se tornam fidelizados às companhias e estas ganharão, por sua vez, ainda mais.

Muitos dos serviços em telefonia fixa e celular são cobrados com maior valor quando se trata de o consumidor ligar para o telefone vinculado à outra operadora. Isso porque existe uma tarifa de interconexão elevada ainda vigente no mercado, embora a Anatel tenha se esforçado para regular o setor de modo a minimizar os efeitos dessas tarifas.

A diminuição das tarifas já estava inserida no contexto da Resolução 576 de 31 de outubro de $2011^{3}$ da Anatel, que aprovou o Regulamento sobre Critérios de Reajuste das Tarifas das Chamadas

3 Referenciado em: <http://legislacao.anatel.gov.br/resolucoes/26-2011/ 69-resolucao-576>. Acesso em: 21 set. 2015. 
do Serviço Telefônico Fixo Comutado (STFC), abrangendo tanto o serviço móvel pessoal quanto o serviço móvel especializado, bem como previsto no Plano Geral de Metas de Competição (PGMC) de 8 de novembro de 2012, ${ }^{4}$ com alguns mecanismos de redução de tarifas de interconexão até o ano de 2016.

A regulação dos serviços de telecomunicações tem, portanto, enfrentado imensos desafios. Muitas vezes, também, os serviços prestados por algumas companhias são alvos de questionamento junto à Anatel pelos consumidores, bem como em órgãos como a Fundação Procon (Programa de Proteção e Defesa do Consumidor).

No ranking de atendimentos do Procon-São Paulo, ${ }^{5}$ por exemplo, no acumulado do ano 2013, constava uma lista com trinta empresas/ grupos que registraram os maiores dados de atendimentos junto ao órgão do consumidor. Nesse ranking é fundamental afirmar que há diversos segmentos envolvidos, que abrangem desde companhias do varejo até bancos, mas a liderança é de uma companhia do setor de telecomunicações, isto é, o grupo Vivo/Telefônica com 11.894 atendimentos e 93,33\% de atendimentos solucionados, a Claro comparecia na terceira posição (6.899 atendimentos, $85,23 \%$ solucionados), Tim Celular S/A na sexta posição (4.172 atendimentos, 84,83\% solucionados), Grupo NET na sétima posição (4.064 atendimentos, 91,22\% solucionados), Grupo Oi na oitava (3.662 atendimentos, 73,98\% solucionados), Sky Brasil Serviços Ltda. na décima (2.701 atendimentos, $89,09 \%$ solucionados $)$ e o UOL na décima sexta posição $(1.428$ atendimentos, $65,65 \%$ solucionados).

Outros indicadores importantes foram divulgados pela Anatel, em 2013, no sentido de apresentar dados ${ }^{6}$ para o setor, com a "Pes-

4 Referenciado em: <http://legislacao.anatel.gov.br/resolucoes/26-2011/ 69-resolucao-576>. Acesso em: 21 set. 2015.

5 Disponível em: <www.procon.sp.gov.br/pdf/ranking_atendimentos_2013_ procon_sp.pdf $>$. Acesso em: 21 set. 2015.

6 Os dados apresentados nesse parágrafo e no subsequente foram extraídos a partir da apresentação da "Pesquisa nacional de satisfação dos usuários de serviços de telecomunicações” da Anatel, 2013. Disponível em: <www. anatel.gov.br/Portal/exibirPortalNoticias.do? acao=carregaNoticia\&codigo $=28725>$. Acesso em: 21 set. 2015. 
quisa nacional de satisfação dos usuários de serviços de telecomunicações", em que é possível identificar as companhias com maior índice de satisfação junto aos consumidores brasileiros. No serviço móvel pessoal pós-pago, a Sercomtel, vinculada ao governo de Londrina, liderava o índice de satisfação com $61,1 \%$, seguida pela operadora do Triângulo Mineiro CTBC 55,9\% e, só depois, pelas grandes que dominavam o mercado, em termos de Market share, a exemplo da Vivo (55,5\%), Claro (54,7\%), Oi (49,9\%) e Tim (49,8\%), ficando o segmento com índice geral de satisfação em 53,7\%.

Já no serviço de TV (Direct to home), a Nossa TV, vinculada a Igreja Internacional da Graça de Deus e ao missionário R. R. Soares, detém $75,9 \%$ de satisfação, seguida pelas operadoras Via Embratel 72,8\%, Sky 72,7\%, Oi TV 70,7\%, Telefônica TV Digital 67,7\% e CTBC 67,0\% com um índice de satisfação do setor de 72,2\%.

O mercado, nessa perspectiva, sob o domínio da Geografia do meio técnico-científico-informacional, contém e é dominado pelos interesses e estratégias corporativas das grandes empresas globais e pelo papel, muitas vezes, subalterno dos governos. Por conseguinte, as empresas agem de modo indiscriminado, concorrendo pela globalização do território, movidas pela ação de diferentes capitais no mundo do dinheiro, das finanças e da economia informacional e, por conseguinte:

Sem dúvida, existe dentro de um território uma oposição entre escalas. Cada escala corresponde a um nível de intencionalidade de um governo de estado, ou de município, ou de uma agência regional. O nível de intencionalidade da firma que usa o espaço nacional como um todo não é o mesmo, nem tem a mesma qualidade ou direção que o de uma firma que apenas pode utilizar-se de uma fração do espaço, ou que tenha seu raio de ação limitado a apenas alguns bairros dentro de uma cidade [...]. (Santos, 1996b, p.82)

Santos (1996b) expõem nitidamente a análise da escala e a intencionalidade envolvida nesse contexto. Para o autor, a escala sempre 
estará vinculada à intencionalidade de um dado governo, seja ele federal, estadual ou municipal.

Além disso, é preciso ter claro que compreender a questão da escala não é um fato tão simples. Incorporada pela Geografia, largamente, poucos são aqueles profissionais que empreendem um estudo mais aprofundado a respeito. Muitas vezes, tal noção é vista apenas pela matemática de uma projeção cartográfica, se resumindo numericamente ou graficamente a uma fração para a compreensão de um espaço meramente abstrato. Mas o "recorte espacial” (nível de análise) da Geografia também pode ser estabelecido tendo em vista a "ordem de grandeza" (dimensão) a ser estudada e percebida, em termos de "nível de concepção", como escreveu Lacoste (1976, p.62).

Castro (2005), por sua vez, considerou que se deve fazer uma divisão para o entendimento da escala, ou seja, não se pode confundir a escala cartográfica com escala geográfica, e a primeira é: "[...] uma fração que indica a relação entre as medidas do real e aquelas da sua representação gráfica [...]" (Castro, 2005, p.117); e a geográfica não pode se resumir a uma representação meramente gráfica do território, mas "[...] expressar a representação dos diferentes modos de percepção e concepção do real” (Castro, 2005, p.118) e, portanto, pode ser interpretada:

[...] como uma estratégia de aproximação do real, que inclui tanto a inseparabilidade entre o tamanho e o fenômeno, o que a define como problema dimensional, como a complexidade dos fenômenos e a impossibilidade de apreendê-los diretamente, o que coloca também como problema fenomenal. (Castro, 2005, p.118)

Entretanto, é preciso fazer uma ressalva de que a escala não deve ser enxergada apenas como zoom para a leitura do território, procurando demonstrar as contradições do processo e os agentes envolvidos no uso corporativo do território. Denota, consequentemente, uma complexidade e abrangência que se relaciona ao entendimento do território enquanto arena de disputas e interesses variados, o que requer, em termos analíticos, uma articulação entre o local e global. 
Dicken (1998), nesse contexto, explorou particularmente as relações entre corporação, transnacionais e o Estado para efetuar um recorte, em termos de escalas. Tal autor concebia a leitura espacial da sua obra por meio de três lentes geográficas, o que traduzimos a partir da interpretação do trabalho como "macro, micro e uma escala intermediária (meso)" e, com isso, grosso modo, as escalas podem ser compreendidas, segundo a nossa interpretação acerca deste autor em:

I. Macroescala - tríade global composta por América do Norte (Nafta), União Europeia, e pelo Leste e Sudeste Asiático. A proposição da Global Triad foi descrita por Kenichi Ohmae (1985) e, nesse sentido, a economia mundial seria organizada de forma tripolar;

II. Escala intermediária (meso) - são considerados como os aglomerados da produção econômica que transcendem as fronteiras entre países na forma de clusters e corredores que promovem a articulação entre diversos centros urbanos. Para tanto, o autor cita três exemplos a respeito da compreensão dessa escala, a saber: a) eixos de crescimento econômico na Europa Ocidental, que reúne cidades como Madri, Valência, Barcelona, Toulouse, Marselha, Lyon, Paris, Londres, Roterdã, Stuttgart, Roma, Nápoles, entre outras; b) corredores urbanos emergentes na Ásia com economia complementar, representados pelo Triângulo Singapura, Batam, Johor e China, Hong Kong e Taiwan; c) zona de fronteira entre Estados Unidos e México, que incluiria uma área altamente rica nos Estados Unidos e uma mais pobre no México, com a produção das maquiladoras;

III. Microescala - denominada pelo autor como um conjunto de "grãos" finos, na forma de mosaico, são os locais onde vivem a maioria das pessoas, a exemplo das cidades e vilarejos. De forma articulada, esse conjunto de localidades pode desenvolver determinada área de um país, como ocorreu na China com as Zonas Econômicas Especiais. 
Tendo em vista ainda as proposições de autores como Lacoste (1976), Dicken (1998) e Castro (2005), é possível definir para o Brasil uma leitura escalar a partir do território. Nessa concepção, o território passa a ser interpretado pela articulação de escalas da nação (território nacional), regiões (áreas de operação das companhias) e os locais (a cidade e o campo) com o global (o mundo das corporações no processo de internacionalização da economia), mas, sem perder de vista, obviamente, o papel do Estado, os cidadãos, os fluxos e fixos ao longo do tempo, lembrando que:

O tempo do Mundo é o das empresas multinacionais e o das instituições supranacionais. O tempo dos Estados-Nações é o tempo dos Estados nacionais e das grandes firmas nacionais: são os únicos a poder utilizar plenamente o território nacional com suas ações e os seus vetores. Entre esses dois, haveria um tempo regional, o das organizações regionais supranacionais - e mercados comuns regionais, e, também, das culturas continentais ou subcontinentais [...]. (Santos, 2008, p.38)

Assim, em vários países, a entrada de companhias privadas no setor de telecomunicações ficou condicionada a investimentos nas redes de infraestrutura, visando a sua ampliação ou modernização. Mas nem sempre os governos latinos agiram no sentido de impor condições de investimentos às empresas concessionárias, o que, por outro lado, gerou, muitas vezes, serviços prestados aquém do esperado pelos consumidores, com uma infraestrutura técnica e tecnológica obsoleta, sobretudo do ponto de vista da modernização. Desse modo, enquanto, medidas liberalizantes de privatização já haviam ocorrido no Chile, Peru e Argentina, estas só foram ocorrer em momento posterior no Brasil.

O Quadro 8, por exemplo, ilustra esse cenário apresentando o ano da aprovação de leis de privatizações na América Latina, bem como o período referente à criação das respectivas agências reguladoras. Com isso, é preciso ter em mente que o Chile foi inaugurador do processo de liberalização da privatização recente, apoiando o 
processo de forma bastante rápida e envolvendo diversos setores da economia. Já o Brasil e o Paraguai foram os derradeiros na aprovação de leis de privatização.

Uma característica comum observada no plano da privatização desse grupo de países foi a formação de consórcios ou grupos de atuação para a aquisição de monopólios e espólios de empresas estatais. Esta variável, no entanto, foi paulatinamente sendo alterada, porque parte dos grupos consorciados passou por transformações, fazendo com que houvesse um fenômeno de concentração de poder, em apenas um grupo econômico ou no máximo dois.

A divisão de operação de redes, igualmente, foi um ponto em comum quando analisada a privatização latino-americana. Assim, poderia haver a divisão do sistema de telecomunicações por diversas escalas e recortes, como por estados, interurbano, local ou mesmo internacional, dependendo do país em que foi realizada tal empreitada.

Quadro 8 - Aprovação da lei de privatização e criação de agência reguladora no setor de telecomunicações na América Latina.

\begin{tabular}{|c|c|c|}
\hline País & $\begin{array}{c}\text { Ano da aprovação da lei } \\
\text { de privatização }\end{array}$ & $\begin{array}{c}\text { Ano da criação de } \\
\text { agência reguladora }\end{array}$ \\
\hline Argentina & 1990 & 1990 \\
\hline Bolívia & 1994 & 1994 \\
\hline Brasil & 1997 & 1997 \\
\hline Chile & 1982 & $1977 / 1982$ \\
\hline Colômbia & 1994 & 1994 \\
\hline República Dominicana & 1931 & 1998 \\
\hline Equador & 1993 & 1992 \\
\hline El Salvador & 1996 & 1996 \\
\hline Guatemala & 1996 & 1996 \\
\hline Honduras & 1995 & 1995 \\
\hline México & 1990 & 1995 \\
\hline Nicarágua & 1995 & 1995 \\
\hline Panamá & 1996 & 1996 \\
\hline Paraguai & 2000 & 1995 \\
\hline
\end{tabular}




\begin{tabular}{|c|c|c|}
\hline Peru & 1993 & 1993 \\
\hline Uruguai & 1991 & 2001 \\
\hline Venezuela & 1991 & 1991 \\
\hline
\end{tabular}

Fonte: Referenciado em Murillo (2009, p.19) e na consulta do sítio do governo da República Oriental do Uruguai. Disponível em: <http://www.parlamento.gub.uy/leyes/AccesoTextoLey.asp? Ley=17296\&Anchor=>. Acesso em: 21 set. 2015. Organização: Jurado da Silva (2013).

As alianças do capital nacional com o internacional também devem ser mencionadas, mas a entrada de empresas como Portugal Telecom, Telefónica, Bell Canada, MCI e Telecom Itália, marcou esse cenário de disputa econômica. Ademais, a divisão em bandas A e B no início da privatização do setor de telefonia celular no país evitou inicialmente maior concorrência entre as companhias.

Houve, em termos legais, a formação de um duopólio, o que na prática revelou-se em monopólio, no qual as empresas privatizadas do sistema Telebrás foram as herdeiras de amplo mercado consumidor e passaram a concentrar o mercado com maior poder de ação espacial e econômica. Antes, medidas na legislação normatizavam e impediam a entrada de um mesmo grupo em mais de uma área de concessão, mas, aos poucos, fusões e aquisições foram ocorrendo.

A Telebrás, nesse cenário, foi preparada institucionalmente para sua privatização, gerando uma divisão da companhia em áreas de concessão, dividindo-a, desse modo, na forma de "lotes espaciais" e o Estado brasileiro como ente regulador e demarcador de normas e da fiscalização do processo; inclusive preparando um marco regulatório antes do processo com a Lei Geral de Telecomunicações e um plano de universalização do setor. Aos investidores externos e internos, a relação de transparência foi dada, mostrando de forma clara as regras do jogo no processo de liberalização da economia.

Com isso, a concorrência passa a ser engendrada no cenário de oligopólio, em que as companhias ao se enfrentarem nacionalmente podem produzir economias de escala com a abertura de diversas alianças e estratégias, no sentido de ampliar sua gama de clientes e novos espaços de acumulação do capital, de maneira concentrada e centralizadora. É preciso destacar, no entanto, que a qualidade dos serviços prestados e o alcance destes à população são feitos de forma 
desigual. Isso porque há áreas na cidade e no campo onde o sinal tende a ser melhor em razão de fatores como a maior densidade populacional e econômica (dado o maior investimento das companhias em dotar tais locais com maior aparato técnico de redes suporte e de serviços) ou mesmo em função do relevo (barreiras geográficas).

Já há algumas cidades pequenas que não gozam, muitas vezes, de todas as companhias operando em seu território, gerando, por conseguinte, uma atuação na forma de monopólio, de modo a só ter uma única empresa a distribuir o sinal de telefonia, ou quando no máximo um duopólio. Tal realidade é constatada até mesmo em São Paulo que é o Estado brasileiro com maior Produto Interno Bruto (PIB).

Tal afirmação é vista em termos estatísticos nas tabelas 8 e $9 . \mathrm{Na}$ Tabela 8, por exemplo, é mostrada a porcentagem de municípios atendidos por operadoras de celular no Brasil de 2008 a 2013. Assim, é possível identificar que em 2013 todos os municípios eram atendidos, embora esse número fosse de 75,49\% em 2008, o que demonstra presentemente que as operadoras estão investindo na ampliação de suas redes técnicas de distribuição de sinal, ao longo do tempo.

Tabela 8 - Porcentagem de municípios atendidos por operadoras de celular no Brasil (2008-2013).

\begin{tabular}{c|c|c|c|c|c|c}
\hline Municípios & $\mathbf{2 0 0 8}$ & $\mathbf{2 0 0 9}$ & $\mathbf{2 0 1 0}$ & $\mathbf{2 0 1 1}$ & $\mathbf{2 0 1 2}$ & $\mathbf{2 0 1 3}$ \\
\hline Atendidos & $75,49 \%$ & $88,86 \%$ & $97,18 \%$ & $99,98 \%$ & $100,00 \%$ & $100,00 \%$ \\
\hline 1 prestadora & $19,54 \%$ & $29,65 \%$ & $38,26 \%$ & $39,71 \%$ & $37,34 \%$ & $36,57 \%$ \\
\hline $\begin{array}{c}2 \\
\text { prestadoras }\end{array}$ & $10,24 \%$ & $11,92 \%$ & $11,93 \%$ & $12,62 \%$ & $13,91 \%$ & $13,96 \%$ \\
\hline $\begin{array}{c}3 \\
\text { prestadoras }\end{array}$ & $15,17 \%$ & $10,50 \%$ & $11,59 \%$ & $7,22 \%$ & $8,05 \%$ & $8,36 \%$ \\
\hline $\begin{array}{c}4 \\
\text { prestadoras }\end{array}$ & $29,67 \%$ & $35,37 \%$ & $34,25 \%$ & $38,94 \%$ & $39,16 \%$ & $37,92 \%$ \\
\hline $\begin{array}{c}5 \\
\text { prestadoras }\end{array}$ & $0,86 \%$ & $1,42 \%$ & $1,15 \%$ & $1,49 \%$ & $1,55 \%$ & $3,20 \%$ \\
\hline $\begin{array}{c}\text { Não } \\
\text { atendido }\end{array}$ & $24,51 \%$ & $11,14 \%$ & $2,82 \%$ & $0,02 \%$ & $0,00 \%$ & $0,00 \%$ \\
\hline
\end{tabular}

Fonte: Anatel e extraído de Teleco. Disponível em: <www.teleco.com.br/cobertura.asp>. Acesso em: 21 set. 2015.

* Os dados de 2013 se referem a dezembro e foram reformatados por Jurado da Silva (2014). 
Tabela 9 - Porcentagem da população atendida por operadoras de celular no Brasil (2008-2013).

\begin{tabular}{l|l|l|l|l|l|l}
\hline População & $\mathbf{2 0 0 8}$ & $\mathbf{2 0 0 9}$ & $\mathbf{2 0 1 0}$ & $\mathbf{2 0 1 1}$ & $\mathbf{2 0 1 2}$ & $\mathbf{2 0 1 3}$ \\
\hline Atendida & $93,91 \%$ & $97,63 \%$ & $99,55 \%$ & $99,99 \%$ & $100,00 \%$ & $100,00 \%$ \\
\hline 1 prestadora & $4,48 \%$ & $7,02 \%$ & $9,30 \%$ & $9,33 \%$ & $8,29 \%$ & $7,98 \%$ \\
\hline 2 prestadoras & $4,26 \%$ & $4,84 \%$ & $4,80 \%$ & $4,98 \%$ & $5,36 \%$ & $5,17 \%$ \\
\hline 3 prestadoras & $8,47 \%$ & $4,04 \%$ & $7,65 \%$ & $3,17 \%$ & $3,49 \%$ & $3,56 \%$ \\
\hline 4 prestadoras & $66,55 \%$ & $70,55 \%$ & $68,50 \%$ & $72,75 \%$ & $73,11 \%$ & $67,62 \%$ \\
\hline 5 prestadoras & $10,14 \%$ & $11,17 \%$ & $9,30 \%$ & $9,76 \%$ & $9,75 \%$ & $15,67 \%$ \\
\hline Não atendida & $6,09 \%$ & $2,37 \%$ & $0,50 \%$ & $0,01 \%$ & $0,00 \%$ & $0,00 \%$ \\
\hline
\end{tabular}

Fonte: Anatel e extraído de Teleco. Disponível em: <www.teleco.com.br/cobertura.asp>. Acesso em: 21 set. 2015.

* Os dados de 2013 se referem a dezembro e foram reformatados por Jurado da Silva (2014).

Entretanto, é preciso atentar para o fato de que aumentou, nesse período, o número de municípios que só possuíam uma operadora em seu território: de 19,54\%, em 2008, para 36,57\%, em 2013; portando-se como ação de monopólio nesses municípios, o que correspondeu à cifra de 7,98\% do total da população brasileira, segundo dados da Anatel (vide Tabela 9). A situação de duopólio era verificada, em 2013, em 13,96\% dos municípios e em 5,17\% total da população no território. Somente $37,92 \%$ dos municípios contavam com 4 operadoras, ou seja, 67,62\% da população brasileira vivia a situação de oligopólio.

Em outras palavras, enquanto o oligopólio era uma realidade no plano nacional e nos grandes centros, nos pequenos centros, interioranos, afastados das capitais e dos recursos o quadro era outro: o do monopólio ou quando no máximo duopólio. Lembrando que a temática do oligopólio, nesse caso, é de difícil generalização. Paul Sweezy já havia afirmado, em momento anterior, que o oligopólio fazia parte da economia moderna e que sua generalização poderia ser restrita ao argumentar que:

[...] Oligopoly is probably the typical case throughout a large part of the modern economy, and yet the theory of oligopoly can scarcely be said to be in a very advanced, consisting as it does of a num- 
ber of special cases which allow of little generalization. (Sweezy, 1939, p.568)

Além disso, é preciso elucidar que "No mercado oligopolista a empresa determina preço e volume com base na expectativa de comportamento dos concorrentes" (Sauaia; Kallás, 2007, p.82). Por sua vez, esse quadro acaba por colocar a população em situação complicada, uma vez que os rendimentos médios auferidos pelas famílias no país não são um dos maiores no mundo, abocanhando importante fatia do total dos dispêndios efetuados pelos trabalhadores mensalmente. No estudo Information Economy Report 2011 da ONU (Organização das Nações Unidas), por meio da UIT (União Internacional de Telecomunicações), ficou evidente essa informação ao apontar que "[...] o Brasil aparece como um dos países em desenvolvimento em que o preço da ligação de celular é o mais caro [...]."”

Há de se ressaltar, no entanto, que no caso dos serviços de telecomunicação no Brasil se tem uma regulação por parte do Estado que interfere no ingresso de novos concorrentes no mercado, bem como nos preços e tarifas praticadas pelos produtos e serviços ofertados, conferindo ao setor determinadas barreiras, mas que demarca nesse espaço de concorrência a participação de empresas que concentram o mercado, em termos de Market share, volume de capital investido, lucros, visibilidade na mídia e na oferta de produtos.

Carvalho (2000), por exemplo, avaliando a estrutura dos padrões de concorrência, em termos teóricos, defendeu que:

De fato, o conceito de barreiras à entrada ao ser introduzido no campo da análise da estrutura de mercado e da formação de preços em oligopólios, sugere que a ameaça de entrantes potenciais é um fator decisivo na determinação dos preços, nos mercados oligopolistas, por implicar na fixação de um limite superior para o preço e

7 Disponível em: <www.onu.org.br/minuto-da-telefonia-movel-no-brasil-e-um-dos-mais-caros-entre-paises-em-desenvolvimento-revela-onu/>. Acesso em: 21 set. 2015. 
portanto para os lucros por parte das empresas líderes que assim se sentem seguras de manter-se no mercado sem induzir a entrada de novos concorrentes. (Carvalho, 2000, p.5)

No caso brasileiro, as companhias também se articulam para produzir determinados efeitos no mercado. Trata-se de um mercado que abrange produtos e serviços praticamente homogêneos. Pouco se diferenciam entre si, em termos tecnológicos, e apresentam preços semelhantes, sendo que grande parte da ação de capital é dada por ações de marketing, bem como por investimentos em infraestrutura das quatro principais companhias em atuação no uso do território.

Os aspectos regulatórios do setor, a grande soma de investimentos, o grau de investimento em tecnologia dificultam, portanto, em primeira e última instância a entrada de novos concorrentes. Players esses que entrarão no mercado, especialmente por via da negociação de papéis em bolsas de valores, ou mesmo adquirindo companhias por meio da oferta direta aos controladores dos grupos, como se deu, por exemplo, com a entrada da companhia mexicana vinculada à Telmex, que comprou o controle da Embratel.

Investir na oferta de serviços diferenciados, tecnologias e produtos exclusivos são algumas das estratégias adotadas pelas companhias, na produção do uso corporativo do território. Ademais, muitas ações corporativas produzidas por uma dada companhia podem interferir no comportamento das outras, como ocorreu com a $\mathrm{Oi}$ ao anunciar a campanha pelo desbloqueio de celulares para ingresso de chips concorrentes com a sátira "Quem ama bloqueia", veiculada, em 2007, em diversas peças publicitárias que obteve grande visibilidade do público, ao convocá-lo para uma mobilização pelo desbloqueio.

Ademais, as táticas e estratégias de visibilidade na mídia, bem como de intervenção espacial podem ser as mais variadas possíveis, levando em conta sempre o aspecto do ganho e da ampliação do Market Share. Os cidadãos são, nesse universo, a unidade escalar básica para a avaliação de como as empresas usam o território de modo a estimular o consumo e auferir o maior lucro a partir da economia diária das populações, no globo, onde a ideia de mercado 
livre é no mínimo cínica e incorreta e "[...] nesse sentido falar em uso corporativo do território é a categoria adequada para expor a normatividade interna da forma hegemônica de compartilhar o espaço no capitalismo contemporâneo [...]" (Kahil, 2010, p.478).

A ação humana, ao incorporar o espaço e dar vida a ele, permite avaliar que os objetos técnicos não devem ser estudados de forma estanque sem levar em conta o caráter da intencionalidade (Santos, 1996). A intencionalidade também se faz presente nas estratégias das corporações, bem como nas transformações socioespaciais decorrentes dos diferentes tipos de uso corporativo do território, alicerçados na produção de objetos técnicos variados, com vistas à reprodução e ampliação do capital.

Além disso, tais objetos e ações são mediados pelo mundo das normas. Para o Grande Dicionário Houaiss da Língua Portuguesa, as normas dizem respeito àquilo "que regula procedimentos ou atos; regra, princípio, padrão". ${ }^{8}$ Por conseguinte, é preciso ter em vista que as normas podem autorizar/desautorizar, conceder/desapropriar, liberar/proibir, limitar/abrir, flexibilizar/endurecer as ações dos sujeitos e das corporações do ponto de vista de sua ação política no território, influenciando diretamente no jogo de poder de sua ação, e "A ordem mundial é cada vez mais normativa e, também, é cada vez mais normada. Esse fato responde à preeminência da técnica em todos os aspectos da vida social [...]” (Santos, 2008, p.229).

As normas, em geral, são quase que invariavelmente definidas pelo Estado por meio de leis, decretos, regulamentações, bem como vigiadas pelos seus canais de repressão e instâncias burocráticas de fiscalização. Porém, não se deve esquecer que atualmente as companhias também têm grande poder de pressão junto aos governos para transformar e alterar as normas vigentes de acordo com interesses convenientes. Ademais, deve-se ter em vista que nesse quadro: "Ao estudo da história segue o estudo das leis, que regulam as relações entre governantes e governados, o conjunto das normas

8 Extraído de: <http://houaiss.uol.com.br/busca?palavra=norma > Acesso em: 21 out. 2013. 
que constituem o direito público uma categoria ela própria doutrinária [...]” (Bobbio, 1992, p.54) e, por isso:

No mundo dos estados, a única lei reconhecida é a lei do mais forte, porque o Estado ou é a maior concentração de força existente num determinado território ou não é Estado. Portanto, não tenhamos muitas ilusões [...]. (Bobbio, 1995, p.180)

Por conseguinte, há determinados tipos de normas que são alheias ao uso nacional do território e fazem parte de um contexto de ação global de certos organismos como a International Telecommunication Union (ITU), no seu correspondente em Português: União Internacional de Telecomunicações (UIT), vinculada à Organização das Nações Unidas, que se dedica:

[...] a temas relacionados às Tecnologias da Informação e Comunicação (TICs). Ao longo dos seus 145 anos de existência, a UIT tem coordenado o uso global compartilhado do espectro de radiofrequência, promovido a cooperação internacional na área de satélites orbitais, trabalhado na melhoria da infraestrutura de telecomunicações junto a países em desenvolvimento, estabelecido normas mundiais para prover interconexão entre vários sistemas de comunicação, além de dedicar especial atenção a temas emergentes mundiais tais como mudanças climáticas, acessibilidade e fortalecimento da segurança cibernética. ${ }^{9}$

Mas não são somente os organismos internacionais que fazem parte desse arranjo de normas presentes no período vigente. As corporações desafiam cada vez mais o poder dos governos, impondo muitas vezes a estes sua intencionalidade e ação no campo normativo, fazendo com que os governos sejam mais flexíveis e capazes de alterar leis de acordo com os interesses de corporações

9 Disponível em: <www.onu.org.br/onu-no-brasil/uit>. Acesso em: 21 out. 2015 . 
que atuam globalmente, como ocorre no setor de telecomunicações no território brasileiro, sendo que agora:

[...] O poder não reside no caráter dominador da empresa que manipularia os dominados; reside em estratégias que combinam códigos diferentes e, de fato, opostos: territorialização versus desterritorialização, estabilidade versus espaço abstrato. O conflito é portanto inevitável e sobretudo desigual, uma vez que a empresa, manipulando a repartição de fluxos de energia simbólica e de informação, não se expõe muito à resistência da população ativa [...]. (Raffestin, 1993, p.95).

Também, nesse quadro, é preciso levar em conta que muitos autores debatem o Estado sem sequer se dar conta de que este é uma construção histórica, social, política, militar, geográfica e econômica e, portanto, é preciso destacar antes de tudo que:

[... Este conceito vem evoluindo desde a antiguidade, a partir da polis grega e da civitas romana. A própria denominação de Estado, com a exata significação que lhes atribui o direito moderno, foi desconhecida até o limiar da Idade Média, quando as expressões empregadas eram rich, imperium, land, terrae etc. Teria sido a Itália o primeiro país a empregar a palavra Stato embora com uma significação muito vaga. A Inglaterra, no século XV, depois a França e a Alemanha no século XVI, usaram o termo Estado com referência à ordem pública constituída. Foi Maquiavel, criador do direito público moderno quem introduziu a expressão, definitivamente na literatura científica. (Maluf, 1982, p.35-36)

Por conseguinte, é preciso destacar que grande parte dos intelectuais contemporâneos quase que invariavelmente recorrem a Maquiavel para tecer seus comentários teóricos como ficou claro na obra de Gramsci (1976), intitulada: Maquiavel, a política e o Estado moderno. Para este autor, por exemplo, há relação de forças que são sociais, políticas e militares. Estas, no entanto, só devem ganhar maior 
sentido se acrescentado, segundo nossa concepção, o debate das forças econômicas e dos usos derivados do poder corporativo no território.

Já Foucault é outro autor que tem se dedicado ao tema do Estado e, sobretudo, do poder. Tal autor exerce grande influência teórica no mundo contemporâneo, dissertando sobre temas como estratégias, arqueologia do saber, prisão, loucura e sexualidade. $\mathrm{O}$ autor não estando confinado somente a um campo do conhecimento escreveu que: “'Dominar', 'dirigir', 'governar', 'grupo no poder', 'aparelho de Estado' etc., há nisso tudo um jogo de noções que demandam ser analisadas” (Foucault, 2012, p.42).

Nos estudos de Foucault (2001 [1979]) há certa preocupação com a Geografia, que pode ser mais bem identificada quando o autor descreveu que o: "[...] Território é sem dúvidas uma noção geográfica, mas é antes de tudo uma noção jurídico-política: aquilo que é controlado por um certo tipo de poder" (Foucault, 2001, p.157).

O poder, por sua vez, é identificado como um instrumento repressivo desde Hegel e não deve ser buscado em sua fonte seminal a partir da perspectiva individual, mas por suas tramas, redes, tessituras; como ocorre no caso do estudo das operadoras de serviços de telecomunicações que se estruturam em densas redes de atuação e, muitas vezes, com alcance espacial internacional amplo. Nas palavras de Foucault (2001, p.83):

[...] O poder deve ser analisado como algo que circula, ou melhor, como algo que só funciona em cadeia. Nunca está localizado aqui ou ali, nunca está nas mãos de alguns, nunca é apropriado como uma riqueza ou em bens. O poder funciona e se exerce em rede. Nas suas malhas os indivíduos não só circulam mas estão sempre em posição de exercer este poder e de sofrer sua ação; nunca são o alvo inerte ou consentido do poder, são sempre centros de transmissão [...]. (Foucault, 2001, p.183)

Como centros de transmissão dotados de ampla capacidade e difusão de poder no território, as empresas de telecomunicações privadas no Brasil comportam-se como a espinha dorsal da infra- 
estrutura informacional do país. Tais empresas são as responsáveis por levar em "ondas" ou em "cabos" a informação a toda parte do território, controlando o elemento essencial do desenvolvimento econômico atual e que move a sociedade cada vez mais para uma interface com a máquina.

Para a compreensão dessas empresas é preciso ter em vista o mercado no qual pretendem se instalar e fixar. Devem ser levados em conta possíveis padrões e potenciais de consumo; as normas e leis do país, Estado e município que regem o ordenamento do território; bem como aproximações linguísticas, composição étnica e política semelhante, história em comum, que auxiliem as empresas a encaminhar praticamente um modelo de ação em comum no mercado regional, a exemplo da América Latina.

Por outro lado, é preciso destacar que surgem na América Latina grandes corporações capazes de concorrer internacionalmente com as empresas vindas de outras partes do mundo e, portanto, segundo uma visão eclética dessa realidade é possível considerar que:

Por se tratar de países altamente regulados pelo governo, com muitas empresas estatais e com barreiras protecionistas, até o começo dos anos 90 muitos dos competidores locais da América Latina não possuíam o nível tecnológico e o know-how necessário para competir com investidores estrangeiros. Entretanto, determinados grupos empresariais latinos aproveitaram-se da ausência de competidores internacionais para aprimorar-se internamente. (Cuervo-Cazurra, 2008). (Melo; Mussengue, 2011, p.67)

Nesse sentido, muitas companhias passaram a atuar fora de seus limites nacionais, sobretudo a partir de estratégias da aquisição de companhias pré-existentes privadas e também pela rentável compra de empresas estatais, em fins da década de 1970 até 1990. É preciso destacar, no entanto, que determinadas companhias internacionais continuaram a investir nesse continente, tendo a Espanha e os Estados Unidos como importantes sócios desse comércio, lembrando que: 
Desde a segunda metade da década de 1990, a Espanha se destaca por ser o segundo maior investidor direto (IDE) na América Latina, estando atrás somente dos Estados Unidos, tradicional investidor nesses mercados. Para se ter ideia desses números, entre 1996 e 2000, 23\% do IDE na América Latina foram representados por empresas espanholas, além de figurar entre 2000 e 2005, em cerca de $12 \%$ dos investimentos nessa região (Toral, 2008). (Melo; Mussengue, 2011, p.68-69)

Além disso, é preciso destacar o investimento espanhol no Brasil, principalmente na área bancária de telecomunicações. Mas, para que fosse viável a ação do capital internacional no mercado brasileiro e latino-americano, foi necessária uma série de regulamentações, reformas setoriais, privatização de empresas e aperfeiçoamento de infraestruturas.

Para que a ação do capital internacional no segmento de telecomunicações pudesse ser realizada com força, foi necessário o aporte bilionário do mercado financeiro e de bancos, a exemplo do que ocorreu com o governo espanhol ao apoiar a aquisição da antiga Telesp no Estado de São Paulo (Melo; Mussengue, 2011, p.70).

Portanto, uma determinada empresa ao internacionalizar-se atua fora do mercado nacional original, podendo lançar mão da criação de subsidiárias no exterior com grande envolvimento de capital e recursos, ou mesmo lidar com operações de atuação mais simplificada, em termos jurídicos. Além disso, pode ingressar em um novo mercado por meio de atividades de licenciamento de marcas, bem como por joint ventures e outras alianças do mundo corporativo, como ocorreu no país com o segmento de televisão por assinatura.

Ademais, verificam-se entre as parcerias do grupo Globo com a Net e a Sky relações estratégicas de aliança complementar, em que esse sócio nacional investe especialmente na área de produção de conteúdo e dispõe de um leque variado de canais, enquanto as operadoras NET e Sky ficam responsáveis pela veiculação desses produtos em sua grade de canais e, nesse sentido: "As estratégias 
cooperativas internacionais permitem que as firmas compartilhem os riscos e recursos para entrar em mercados externos" (Melo; Mussengue, 2011, p.75).

As alianças complementares levam em conta, portanto, o "saber fazer" e o know-how do parceiro, tendo em vista ações em conjunto que possam agregar valor para ambos sócios. Além disso, as fusões e aquisições podem servir para que uma determinada companhia possa atuar em territórios distantes com organização, recurso e ativos distintos.

Pagando a quantia de 655 milhões de dólares (35\% das ações), ${ }^{10}$ por exemplo, ao governo do Rio Grande do Sul pela CRT o grupo “[...] formado por Telefónica Internacional y sus empresas filiales Telefónica de Argentina y Compañía de Telecomunicaciones de Chile, además de la empresa local Rede Brasil Sul" (Rozas Balbontín, 2005, p.31) inaugurou o processo de abertura à iniciativa privada do setor de telefonia contemporaneamente brasileiro.

No leilão da Telebrás, a Telefónica arrematou ainda a Telesp Celular, Tele Leste Celular, Tele Sudeste Celular e a Telesp, cobrindo todo o Estado de São Paulo com o serviço de telefonia fixa e também áreas de grande densidade populacional como os Estados do Rio do Grande do Sul e Rio de Janeiro com a telefonia celular. Por fim, a companhia conseguiu alcançar as metas de universalização ao incorporar a CETERP de Ribeirão Preto, no final dos anos 1990.

No caso ainda do grupo espanhol Telefónica, observa-se que a empresa nasceu em Madri em 1924. Em meados da década de 1940, a companhia negociou suas ações com o governo espanhol, que passou a ser o principal acionista da companhia, tornando-se um dos principais grupos do mundo na década de 1980. (Melo; Mussengue, 2011, p.78)

Depois de algum tempo, a empresa passou a adquirir outras companhias no mundo, atuando na Alemanha, Reino Unido, entre outros. Nos anos 1990, a companhia, controlada pelo Estado, passou para o domínio da iniciativa privada e, com isso:

10 Informação referenciada em Rozas Balbontín (2005, p.31). 
[...] o processo de internacionalização da Telefônica se intensificou na década de 90, por meio de processos de aquisição de vários grupos de telefonia da América do Sul fazendo-se presente na Argentina, no Brasil, na Colômbia, no Chile, no Equador, no México, no Peru, no Uruguai, na Venezuela, além de diversos países da América Central, como a Guatemala, o Panamá, El Salvador e a Nicarágua (Melo; Mussengue, 2011, p.79).

Números do mercado consumidor, o passado colonial, semelhanças linguísticas facilitam o acesso da Telefónica a um mercado gigantesco. A empresa possui o maior número de usuários de serviços de telefonia móvel do Brasil por meio da Vivo, a segunda posição no mercado de telefonia fixa, fazendo do país o principal centro de atuação da empresa no mundo.

No passado, em 2001, a companhia incrementou seu poder no território ao se aliar com a Portugal Telecom no mercado de telefonia celular, dando origem a maior companhia de celular brasileira: a Brasicel, que é a controladora da Vivo, e que agora também atua no segmento de telefonia fixa, paga e internet, sob uma mesma marca (Vivo). O resultado desse processo normativo, financeiro, político e administrativo foi, do ponto de vista espacial e econômico, a concentração do capital e a centralização do comando pela Telefónica.

No momento, a companhia oferece serviços de internet banda larga especialmente no território paulista, bem como serviço de televisão por assinatura, em algumas partes do território nacional, e o grupo Portugal Telecom deixou o grupo no Brasil para se fundir posteriormente com a companhia $\mathrm{Oi}$, concentrando, evidentemente, o poder da companhia no grupo Telefónica. Outro fato também relevante é o controle do provedor Terra que assegura ao grupo posição estratégica no mercado de internet no Brasil e regionalmente, na América Latina, com o investimento em diversos países.

Recentemente, a Telefónica cresceu sua participação em termos acionários na Telco, que é controladora da Telecom Itália e, por extensão, da TIM no Brasil. Assim, no momento, há no cenário de disputa entre as companhias um fato novo que, todavia, encontra- 
-se em andamento. Não se sabe qual será mais adiante o entendimento do Cade (Conselho Administrativo de Defesa da Concorrência), no Brasil, a respeito do futuro da TIM, mas é possível que a companhia seja vendida a Claro, Oi e Vivo, em conjunto, para evitar maior concentração de mercado a favor da Vivo/Telefónica, ou mesmo que um novo grupo internacional ingresse no mercado, sendo amplos os desdobramentos prováveis desse processo.

Já outro grupo importante que disputa a liderança com a Telefónica é a Telmex/América Móvil, sendo o "[...] resultado do investimento de um grupo de mexicano que comprou participações da Sony Ericsson sediada no México [...]” (Melo; Mussengue, 2011, p.81). Já “[...] Em 1950, o mesmo grupo de mexicanos comprou participações da mexicana da ITT Corporation, tornando-se assim o único provedor de serviços telefônicos no país” (Melo; Mussengue, 2011, p.81).

Tal companhia ainda passou para o controle do governo mexicano na década de 1970 e voltou para o controle da iniciativa privada na década de 1990 e, com isso, "[...] a Telmex foi vendida a um grupo de investidores representados principalmente por Carlos Slim, France Telecom e Snowthwestern Bell Corporation" (Melo; Mussengue, 2011, p.81).

A Telmex foi um grande player que praticamente não enfrentou concorrência no México para poder se desenvolver e tornar-se uma das maiores empresas do mundo na área de telecomunicações. No segmento de telefonia móvel, a IUSA Cell era líder nos anos 1990 no México, até que a desvalorização do peso mexicano e a crise financeira favoreceram com que a Telmex também ganhasse a liderança nesse segmento.

A estratégia dessa companhia foi operar no segmento de baixa renda, oferecendo celular pré-pago e firmando-se como principal empresa de telefonia no México, nos anos 2000, especialmente por meio da ação da América Móvil, derivada dos investimentos dessa última. Atualmente, a companhia foca sua atuação em 18 países da América, estando presente em países como Argentina, Chile, Uruguai, México, Estados Unidos entre outros, sendo que no Brasil opera por meio da marca Claro, Embratel e Net. 
A entrada do grupo se deu no Brasil por meio da compra de ações da MCI (empresa norte-americana) por 400 milhões de dólares (Rozas Balbontín, 2005, p.25). Por meio desta ação, a empresa passou a controlar o fluxo de chamada a longa distância nacionalmente e internacionalmente, bem como o serviço de transmissão de dados e, consequentemente, a:

Telecom Americas inició sus operaciones mediante la compra de varias de las empresas operadoras que se constituyeron en la banda $\mathrm{B}$ y cuyos grupos de control no estuvieron dispuestos a emprender las políticas de expansión de otros operadores internacionales, tales como Telefónica, Portugal Telecom y Telecom Italia: Tesse (zona 2), ATL Telecom Leste (zona 3), Telet (zona 6) y Americel (zona 7). (Rozas Balbontín, 2005, p.44)

Além disso, a aquisição das filiais antes pertencentes à BellSouth no Brasil representou o ingresso de uma das localidades mais promissoras da telefonia móvel celular no país. A região metropolitana de São Paulo foi uma dessas áreas com forte adensamento populacional e grande potencial de consumo elegida, em termos de seletividade espacial, para a atuação da empresa.

Em 2003, a companhia continuou com sua lógica de expansão territorial ao dominar a BSE S.A., que operava na região Nordeste, e o resultado foi a entrada no Rio Grande do Norte, Alagoas, Paraíba, Pernambuco, Piauí e Ceará, com uma base de clientes de 6,2 milhões (Rozas Balbontín, 2005, p.45). Ainda nesse mesmo ano, a Telecom Américas deu início ao processo de uma ambiciosa construção de rede GSM no Estado de São Paulo, concentrando seus esforços no sentido de competir fortemente com a Vivo, no campo da telefonia móvel celular.

Porém, a companhia não parou por aí e prosseguiu seu rumo de expansão no Brasil ao comprar licenças que permitiram a ela operar em outras bandas e atingir novos territórios como Bahia, Sergipe, Paraná e Santa Catarina. Atualmente, a empresa opera em todo o território nacional, congregando também esforços na área de 
televisão por assinatura com a Claro TV (direct to home) e por meio da NET (televisão a cabo), nos principais centros consumidores do país, a exemplo da capital São Paulo. O resultado desses esforços é o controle do mercado de televisão paga no Brasil por meio dessa companhia, que é líder do segmento, seguida posteriormente pela Sky e os demais grupos.

A companhia também investiu no serviço de banda larga móvel e fixa, sendo um dos primeiros grupos no país a ingressar no serviço de tecnologia $4 \mathrm{G}$ que está presente nas principais capitais e centros do país, por meio da telefonia móvel celular da Claro.

É preciso frisar, no entanto, que outros grupos foram crescendo, a exemplo da Telecom Itália, que por meio de subsidiária foi adquirindo diversas licenças para operar em amplos territórios, bem como as brasileiras Telemar e Brasil Telecom com a Portugal Telecom, que iriam culminar, mais adiante, na produção da $\mathrm{Oi}$ - Corp Co.

A Tim Participações S.A. adquiriu, por sua vez, a Intelig, que é a empresa espelho que concorre diretamente com a Embratel (vinculada ao grupo mexicano de Carlos Slim). Além disso, controla a Eletropaulo Telecomunicações Ltda. e a Tim Fiber SP e Tim Fiber RJ, no segmento de fibra óptica no país.

Já o seu destino, em termos acionários no país, é indefinido, uma vez que a entrada maior da Telefónica na Telco, que controla a Telecom Itália e, por sua vez, a sua respectiva subsidiária no Brasil, provocará atenção junto aos órgãos reguladores que tomarão, em um futuro bem próximo, uma decisão acerca da condução societária da companhia no país.

Outro grupo que também passa por transformações do ponto de vista de seu crescimento e atuação no mundo é a Oi, que detém investimentos na África e Ásia e que agora se soma aos investimentos da europeia Portugal Telecom, em processo de fusão.

Herdeira da Telemar e da Brasil Telecom, a companhia é líder no segmento de telefonia fixa no país e a quarta companhia em termos de Market Share na telefonia móvel. Outrora, possuiu participações no provedor IG e, no momento, conta com alto investimen- 
to em barda larga fixa e móvel, bem como no mercado de televisão paga com a marca Oi TV.

Dessa forma, é possível falar de quatro grandes grupos (Vivo, Claro, Tim e Oi/CorpCo), em operação, no uso corporativo do território brasileiro, mas que se somam a empreitadas de outras empresas também bastante consolidadas e estratégicas, em seus respectivos segmentos, como na televisão por assinatura com os grupos Globo e Sky e na internet por meio de provedores com a influência do UOL (Folha de S.Paulo), por exemplo.

Consequentemente, a normatização territorial da lógica do uso corporativo do território apresenta-se extremamente complexa, na qual fluxos e fixos são animados pela ação ampliada do capital privado nacional e internacional, bem como com a participação do Estado, no sentido de conferir ao território uma topologia particular, assentada na desigualdade, em termos do uso do território e pela concentração de capital e investimentos em determinadas áreas da nação do ponto de vista de uma seletividade para ação corporativa.

Assim, do ponto de vista das infraestruturas técnicas territoriais como marco da ação dos grupos apresentados e pelo papel do Estado, é possível descrever o território e a forma que ganha essa articulação do ponto de vista material e geográfico. Em outras palavras, tal ideia se concatena à ideia central da obra, no sentido de demonstrar, em termos geográficos, como determinados elementos definidos territorialmente interligam-se, negam-se ou mesmo se sintetizam de forma arbitrária, contraditória e desigual, levando, portanto, em última instância a propor uma área geográfica, na forma concentrada, que envolveria as metrópoles São Paulo, Rio de Janeiro, Belo Horizonte e Brasília e em outra extensão o Sul do país com as regiões metropolitanas de Curitiba, Porto Alegre e em outro extremo Florianópolis e adjacência, compondo, nesse cenário, um desenho geométrico da desigualdade no território. 


\section{Normatização territorial e a expressão geográfica das telecomunicações no Brasil}

O território usado como categoria para a compreensão do jogo de forças estabelecido a partir da dinâmica corporativa das empresas de telecomunicação revela diferenciações quanto ao emprego da técnica na produção territorial e demonstra, por outro lado, aspectos da desigualdade, resultante do poder de força dos lugares, regiões e Estados. Poder este que é exercido, em grande parte, por um conjunto de agentes dominantes que reúne tanto as empresas quanto os governos.

Cada porção do território é construída e usada conforme diferentes lógicas, cabendo ao transporte e às telecomunicações a ligação de diferentes partes da estrutura territorial de um país. Sem o desenvolvimento das telecomunicações e dos transportes, o Brasil seria simplesmente um conjunto de ilhas econômicas sem ligação entre si. O que define as lógicas de acumulação e a integração territorial é, sem sombra de dúvidas, o desenvolvimento de tais setores e, com isso, torna-se importante assinalar que:

Le dévelopment des télécommunications et des transports rapides rend ces progrès particulièrement évidents dans le déplacement des informations, des biens et des personnes; mais les avancées sont aussi considerábles pour les moyens de stockage et d'accumulation, qui permettent non seulement d'accumuler richesses et pouvoirs, mais aussi de faire reculer sans cesse la sphère du périssable. (Ascher, 1995, p.43)

Porém, hoje é preciso levar em conta que é a iniciativa privada que oferece, na maioria das vezes, tais serviços à população e, com isso, há diversas formas de cruzamento de capitais, bem como de operações e dinheiro no território. A mobilidade territorial do capital tem sido bastante elevada quando se observa as associações entre os diversos tipos de capitais, na produção desigual das corporações 
e na expressão geográfica, acompanhada igualmente pela mobilidade setorial do capital.

Assim, Carlos de Mattos (1992, p.156-157) sobre a discussão mais ampla das transformações setoriais e da mobilidade do capital, no contexto geral da América Latina, escreveu sobre a: "[...] deslocalización de ciertos procesos o subprocesos, sean estos propios o subcontratados [...]" (Mattos, 1992, p.157), destacando que:

[... ] se ha ido generalizando una modalidad de organización y gestión empresarial que combina pragmáticamente centralización, según la cual las empresas definen y manejan centralizadamente su estrategia global de valorización del capital, incluyendo a este nivel las tareas concernientes a dirección general, planificación y control y, al mismo tiempo en la medida en que dicha estrategia se complementa con la deslocalización de determinadas inversiones y procesos productivos impulsan una mayor descentralización de la gestión delas divisiones y plantas respectivas. (Mattos, 1992, p.157)

No Brasil, a centralização do capital tem ganhado força especialmente pela ação de grandes grupos que conformam um oligopólio, no plano nacional das telecomunicações, ao mesmo tempo em que forças locais operam territorialmente, por meio de pequenas empresas e dão ao território um significado específico. Além disso, o Estado age, nesse cenário, como regulador e, consequentemente, "[...] jurídicamente la regulación consiste en establecer reglas destinadas a disciplinar una actividad" (Nallar, 1999, p.116).

Não menos distante, tal terminologia advém de um processo anterior que é o da privatização e, desse modo: "[... ] Privatización y regulación son conceptos que, lejos de oponerse, se complementan y coadjuvan al cumplimiento de sus fines: la privatización cuando sus efectos positivos peligran por fallas en el mercado" (Nallar, 1999, p.118). 
O que houve com as telecomunicações no Brasil foi claramente a privatização do setor, mas também uma privatização do território, ao dividir o conjunto das operações em "lotes", em um leilão. Assim, a regulação não deve ser praticada somente sobre o mercado, mas também sobre o território. Com isso, pode-se escrever sobre uma regulação territorial, uma normatização territorial das infraestruturas de telecomunicação e, por fim, de uma regulação do uso corporativo do território e da informação.

Nesse sentido, a informação é o dado essencial da inovação, da reprodução capitalista, favorecendo o deslocamento de ideias, energia, ordem, conectando, desconectando, ligando, desligando, iluminando, obscurecendo a trama reticular das organizações, dos governos, instituições, corporações e pessoas e, portanto:

L'information devient la composante essentielle d'une nouvelle époque sócio-économique (on parle de societé de l'information). Elle està à la base d'une nouvelle revolution industrielle (robotique, conception assistée par ordinateur, modification des conditions de travail dans les bureaux...), elle conduit à de nouveaux modes de vie et à une redéfinition des relations avec l'espace tant au niveau de la vie quotidiene (usages du téléphone) qu'au niveau des forces sociopolitiques [...]. (Bakis, 1987, p.5)

Dessa maneira, a informação como insumo e meio da reprodução do capital é, então, o elemento que possibilita na dinâmica atual a associação de diversos capitais e a mobilidade territorial e operacional destes. A informação é energia que circula por aparatos da técnica, das invenções e inovações que são produzidas, ao longo do tempo, e recebidas por meio da televisão, internet e telefonia, que em diferentes momentos tiveram o papel de colaborar para a integração imaterial do território, seja no Brasil ou no mundo.

Há, logo, uma característica particular estabelecida a partir dos objetos técnicos da inovação, das formas, estruturas e funções que 
são construídas no território pela produção humana que precisam ser mais bem explicadas por meio da Geografia. Assim, do mesmo modo que não há território sem homem, não há homem sem território e um tempo.

Também, é nítido afirmar que não há empresas sem território. As companhias usam o território corporativamente, dando a ele fixos e fluxos, a partir da regulação do Estado e de múltiplos investimentos, em diversas áreas, envolvendo filiais ao longo do globo, pontos, linhas das redes de sistemas técnicos, torres, terminais, centrais, backbones, redes de fibra óptica, satélites, data centers, entre outros. Consequentemente, o território é visto a partir de fixos, que são os pontos de emissão e recepção da informação, no processo de comunicação, mas igualmente por fluxos através da energia circulante, desprendida no processo comunicacional via cabos e satélites, conformando impulsos, ondas e sinais.

Por outro lado, é importante ressaltar que tais corporações são ainda capazes de produzir normas no território, por meio de seus dispositivos e regras de funcionamento, o que implica padrões e princípios de conduta com os consumidores, bem como na produção e uso do território. As normatizações se ajustam territorialmente, inserindo juridicamente um conjunto de regras das quais os consumidores são signatários, por diversos contratos e práticas.

María Laura Silveira (2006, p.95), a respeito dessas articulações do mundo corporativo, destacou que: “[...] Quando as corporações encorajam, segundo várias formas de convicção, a construção das infraestruturas de que necessitam, e quando os governos decidem realizar tais obras, o processo de produção do território corporativo se fortalece $[\ldots]$ ". Tornando-se mais forte, o projeto corporativo das empresas ganha território e competitividade, na busca por ampliação de lucro, bem como importância no mercado e poder.

Nesse sentido, as infraestruturas, o poder e as normas colocam-se como instrumentos eficazes, no processo de controle de determinada tecnologia, bem como no processo de gerenciamento 
das atividades comerciais, financeiras e técnicas, mediadas por "serviços-rede", além das "redes-suporte", na estruturação de uma determinada operação territorialmente, uma vez que, hoje mais do que nunca: "[...] os negócios governam mais que os governos (E. Daszlo, 1992) e, com a globalização da tecnologia e da economia, os Estados aparecem como servos das corporações multinacionais (R. Petrella, 1989) [...]” (Santos, 2008, p.244).

Além disso, muitas normas são impostas por estratégias corporativas específicas, conformando um ordenamento gerencial e administrativo para instalação de infraestruturas em certa porção territorial, modernização de componentes, competição pela ampliação do lucro e avanço sobre determinado nicho comercial. Consequentemente, é preciso destacar que cada local tem, desse modo, uma densidade técnica específica, fruto da sobreposição de diferentes momentos, divisões territoriais do trabalho, da contradição entre o trabalho humano e apropriação da natureza, e:

A acumulação contemporânea (Santos, 1993), encarnada nos macrossistemas técnicos, nas ações corporativas públicas e privadas e no peso das finanças e da informação, contribui para produzir uma valorização e desvalorização frenética dos pedaços do território, o agravamento da pobreza e, em definitivo, uma globalização necessária para quem comanda os processos sociais, porém desnecessário para a maior parte da sociedade. (Silveira, 2006, p.86)

Trata-se, portanto, de uma economia política do território. Tal contexto reúne tanto determinados sujeitos e agentes da produção e domínio territorial, quanto os objetos materiais construídos, apropriados e consumidos de diferentes formas pela sociedade em cada pedaço do território.

Há, assim, na expressão de Santos e Silveira (2006), espaços que mandam (comandam) e outros que obedecem, sendo estes entendidos como sistemas de objetos do ponto de vista estrutural e 
material, mas também sistemas de ações, quando se observa os sujeitos e agentes que produzem tal dinâmica (Santos; Silveira, 2006, p.264-265).

Ainda, para Santos e Silveira (2006, p.264), os espaços que contém a "globalização absoluta" e são mais munidos de densidade de caráter científico, técnico e informacional são denominados de "espaços luminosos", uma vez que: “[...] pela sua consistência técnica e política, seriam os mais suscetíveis de participar de regularidades e de uma lógica obediente aos interesses das maiores empresas" (Santos; Silveira, 2006, p.264). Por sua vez, tais espaços diferem dos espaços opacos que se caracterizam pela debilidade de densidade técnica ou ausência dessa.

Os espaços luminosos são, nesse sentido, produzidos por diferentes agentes e neles estão contidas fortes cargas de densidade técnica, constituídas especialmente pelo poder de normatizar das grandes companhias. Atualmente, tais empresas são organizadas cada vez mais em rede, sendo que uma ordem dada pela matriz ou sede é espalhada para o conjunto de pontos e filiais no globo que a executam com perfeição e, por conseguinte: "[...] as redes depositam uma camada 'geológica' suplementar às 'terras história' acrescentando uma topologia à 'topografia', dando nascimento a um espaço 'contemporâneo do tempo real'” (Musso, 1994, p.256 apud Santos, 2008, p.266).

No Brasil, essa realidade é constatada por meio de corporações instaladas territorialmente que obedecem a lógicas estrangeiras, em sintonia com o desempenho de mercado de outras partes do mundo e, muitas vezes, operando em ação conjunta na vizinhança regional, isto é, na América Latina, observando que:

Firms themselves have territorial extent: the roughly bounded area over which they conduct their operations (e.g.,their market area, their labor catchment area, their supply area). For some functions of the firm the territory may be intensely local, for others 
it may approach the global. Such firm territories, however, are usually temporally volatile, spatially discontinuous, and not clearly bounded. Indeed, firms in competition interpenetrate each other's territories in highly complex and contested ways. (Dicken; Malmberg, 2001, p.355)

Na expressão de Dicken e Malmberg (2001), as companhias acabam por possuírem uma extensão territorial própria que envolve suas operações de diferentes formas, movidas por estratégias diversificadas de negócios. Com isso, um dos grupos que têm elegido o continente americano para operação é a América Móvil, que atua no Brasil por meio da Claro, Embratel e Net. No exterior, a companhia tem focado sua atenção em quase todos os países do continente como demonstra o Mapa 7. Isso facilita, por exemplo, a eleição de estratégias corporativas e territoriais, no sentido de enxergar este mercado como um bloco que apresenta muitas semelhanças, em termos de passado histórico, étnico e econômico.

Outro grupo que também tem concentrado esforços na América é a Telefónica, especialmente por meio da ação da Movistar em países como Argentina, Chile, Peru, Uruguai, Colômbia e Venezuela, como é possível verificar no Mapa 8. No Brasil, a companhia opera, sobretudo, pela Vivo, mas também possui destaque na Europa e operação na China.

A Telecom Itália (vide Mapa 9), por sua vez, mantém foco especialmente no Brasil (Tim), Itália e Argentina (Telecom Argentina), mas atua em outros mercados, a exemplo da Ásia (China e Índia), África, Europa e Oriente Médio. Já a Oi/Portugal Telecom (CorpCo) elegeu para operação áreas que, particularmente, têm a colonização portuguesa como traço comum, como é o caso do Brasil, Angola e Macau, que hoje pertence à China (consulte Mapa 10). 


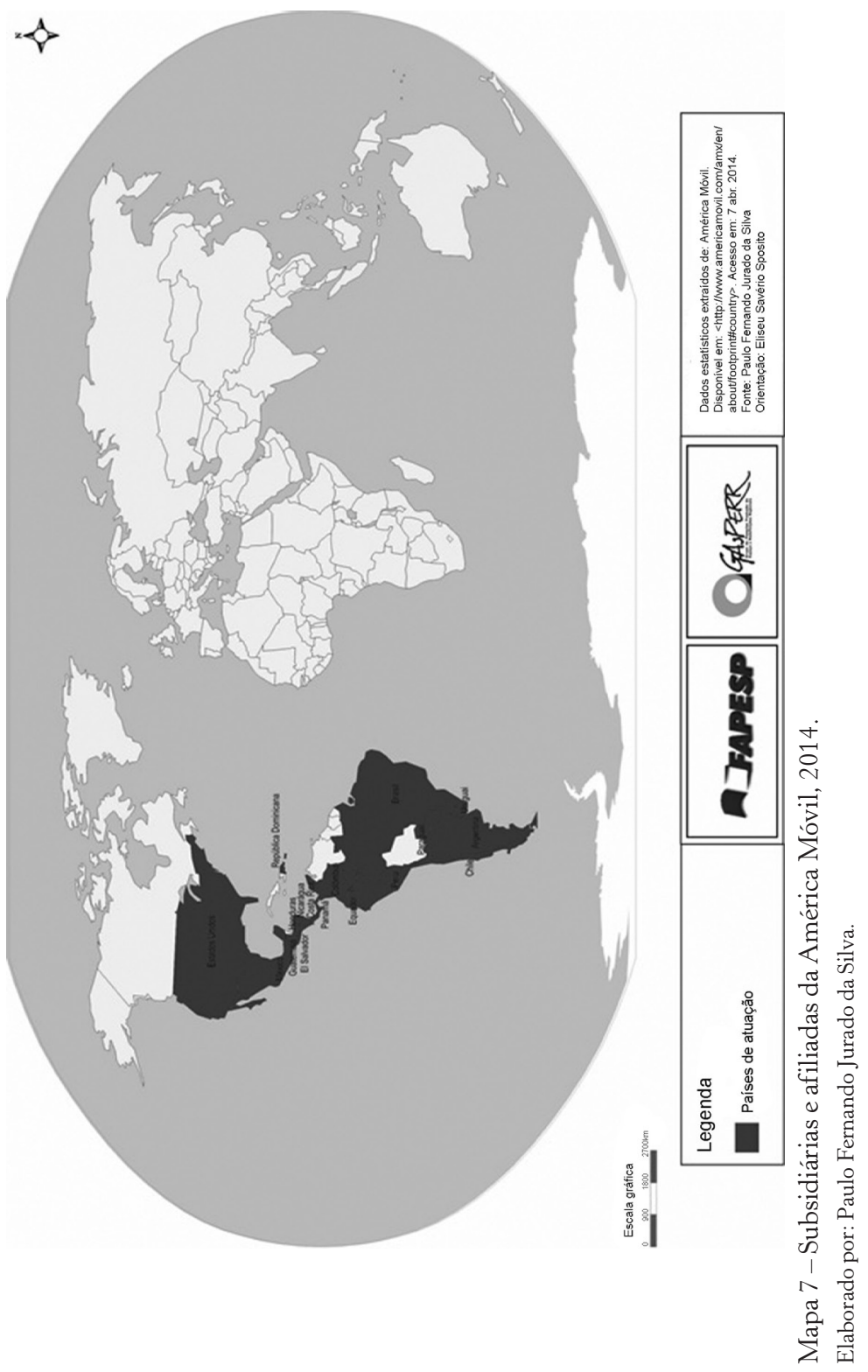




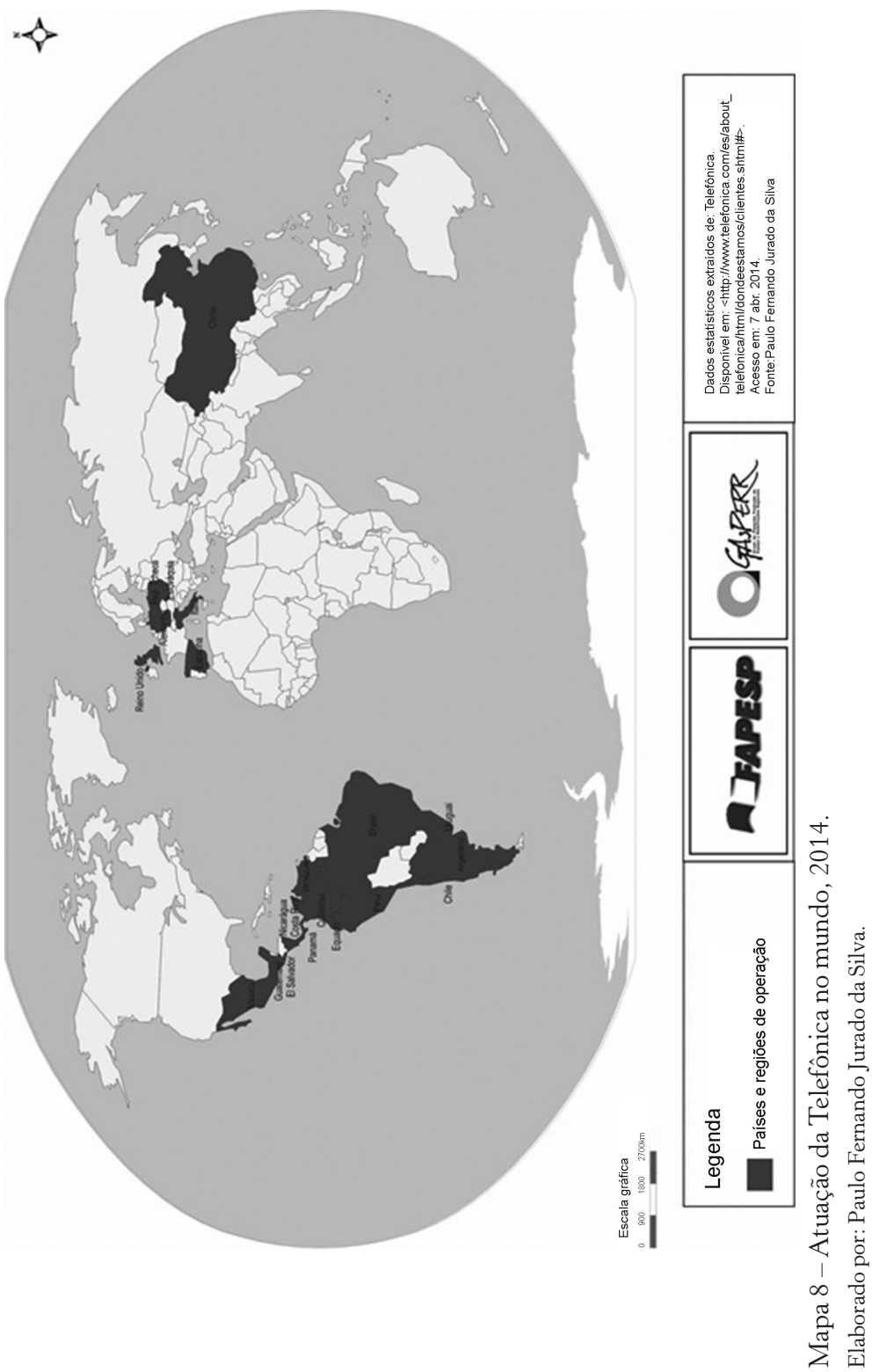




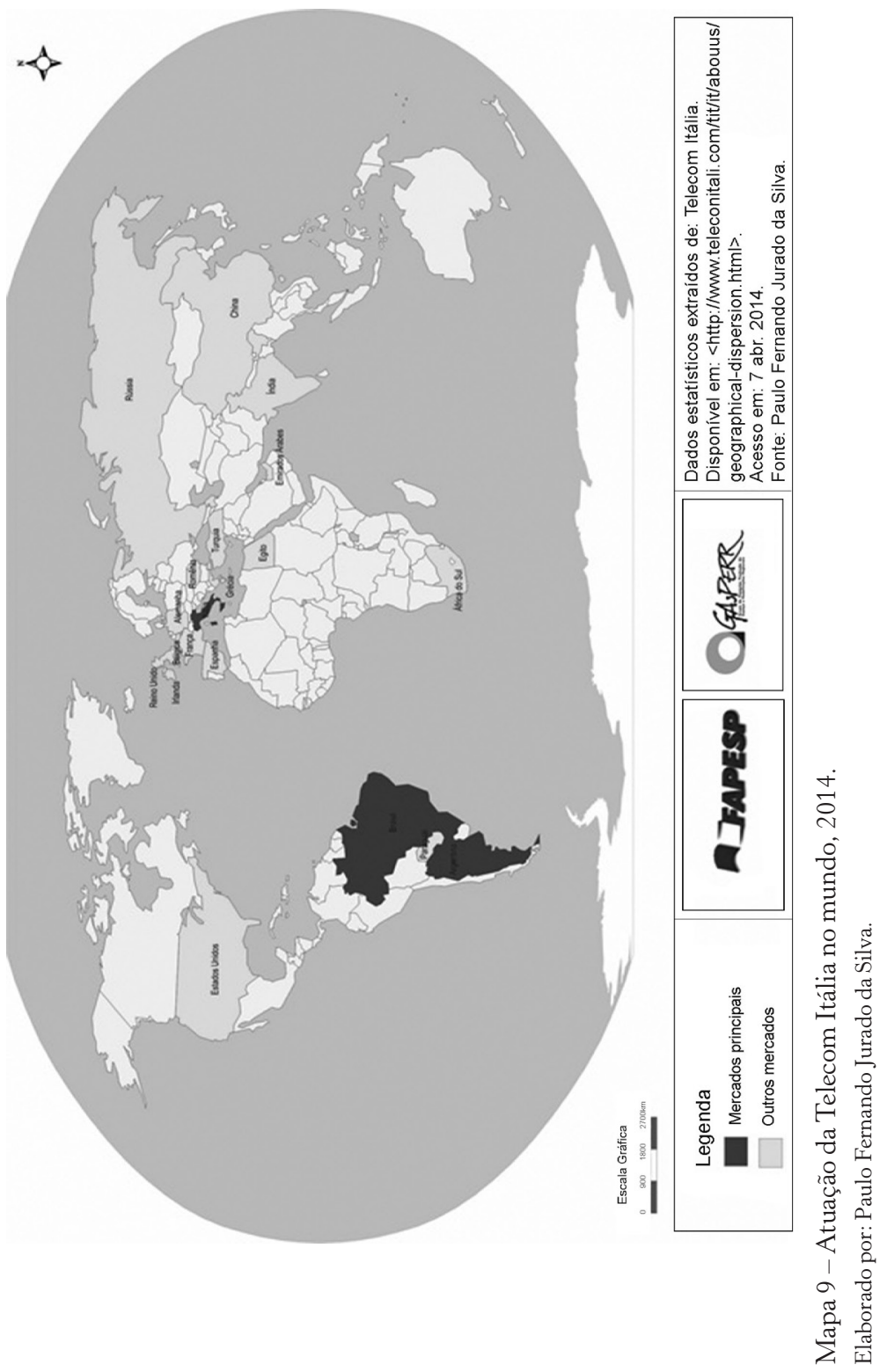




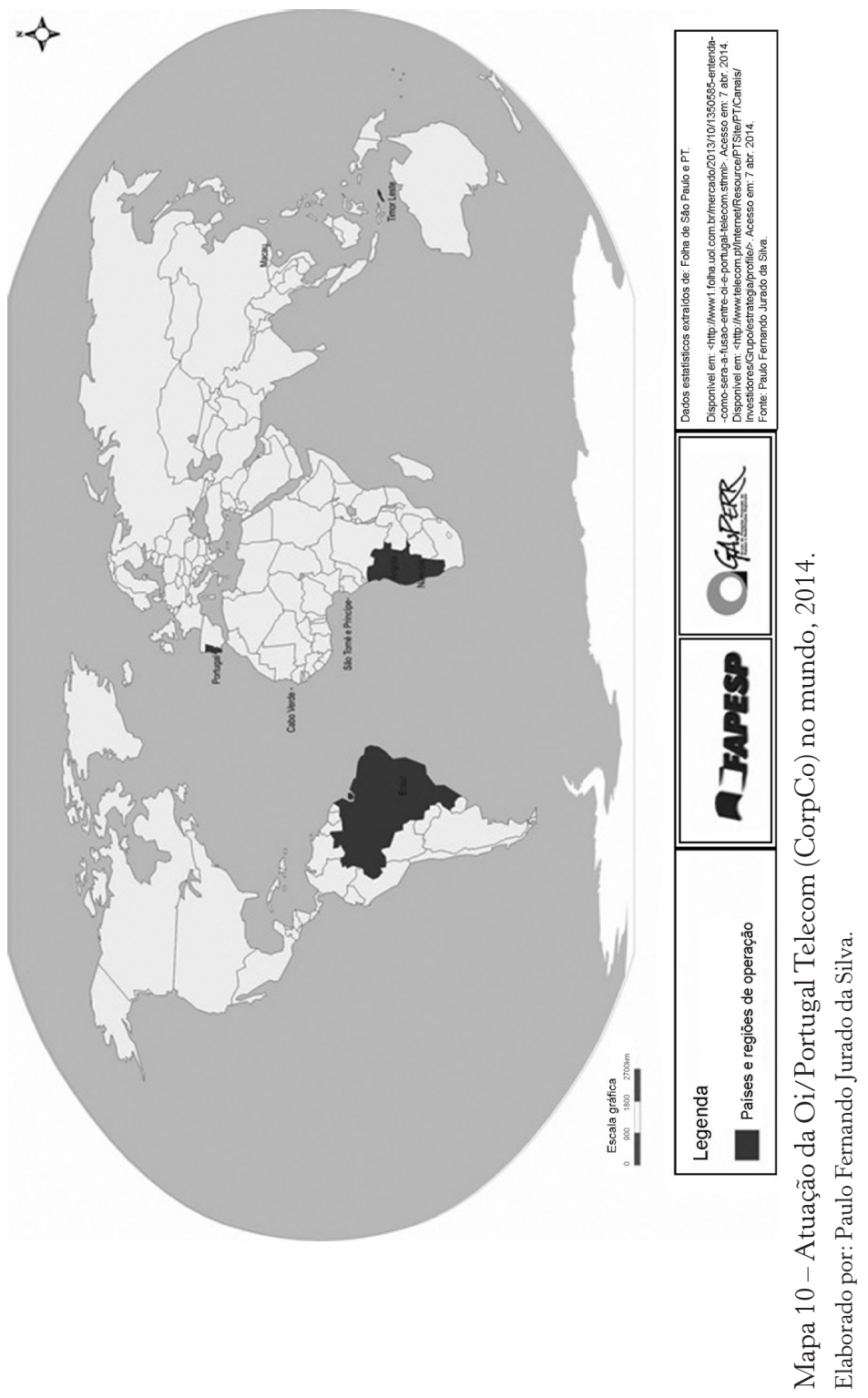


Assim, é preciso ter em vista que a eleição territorial para operação corporativa decorre de vários fatores. Nesse sentido, encontrar semelhanças nos mercados de atuação pode ser um ponto de partida para eleição da estratégia corporativa, visando a uma variável facilitadora para produzir normas de gestão territorial e economia política do território comum.

O território, nessa concepção, por meio de seu uso nas telecomunicações no Brasil é resultante da ação do capital estrangeiro e nacional. Estes, por sua vez, controlam diferencialmente a ação de determinadas empresas na formação de redes de ação e estratégia corporativa, bem como nos projetos de políticas de expansão e na atuação de oligopólios, que marcam presença fortemente, em âmbito internacional.

No caso brasileiro, observa-se que as empresas que hoje são líderes em Market share, são também expressivas na América Latina, sendo o mercado comum a essas grandes corporações que se adaptam às lógicas internas de cada país para reproduzir serviços semelhantes, em toda essa extensão territorial de atuação.

Isso é visível e sentido por meio da análise da paisagem, mas também pelo espaço que anima a vida de relações sociais e dá movimento aos antagonismos, contradições, rupturas, ligamentos, desligamentos, combinações, sínteses e a produção capitalizada do território, das esperanças e das fronteiras, no desenvolvimento desigual e combinado de modo que:

A ordem global é "desterritorializada", no sentido de que separa o centro da ação e a sede da ação. Seu "espaço”, movediço e inconstante, é formado de pontos, cuja existência funcional é dependente de fatores externos. A ordem local, "reterritorializa", é a do espaço banal, espaço irredutível (T. dos Santos, 1994, p.75) porque reúne numa mesma lógica interna todos os seus elementos: homens, empresas, instituições formações sociais e jurídicas e formas geográficas [...] (Santos, 2008, p.338).

Lembrando que a delimitação das telecomunicações no Brasil ganha, com isso, uma lógica não somente nacional para se vincular 
ao mundo, por meio de uma arquitetura densa de cabos submarinos via oceano e a satélites que circulam rotineiramente a Terra, inserindo nesse contexto, o global, o nacional e o local em um plano de intersecção, em que é a escala do local por meio do lugar que acolhe/repele/sintetiza esse universo contraditório, de acordo com a densidade técnica nele inserido.

Os cabos submarinos que atravessam o globo produzindo a topologia de internet no mundo são diversos e, com isso, a topologia pode ser considerada como: "[...] a distribuição no território dos pontos de interesse para a operação dessa empresa. Esses pontos de interesse ultrapassam o âmbito da própria firma para se projetar sobre as empresas fornecedoras, ou compradoras, ou distribuidoras [...]" (Santos; Silveira, 2006, p.292). Porém, a marca territorial dessa expressão é visualizada a cada momento por meio das infraestruturas materiais, do poder e do domínio corporativo exercido a cada operação e uso territorial.

Nesse sentido, é necessário levar em conta que a maioria dos cabos submarinos instalados no mundo tem nos Estados Unidos um grande nó, visando favorecer a entrada e a conexão em outros territórios. Isso significa, por sua vez, que esse país é o centro para onde convergem as telecomunicações no planeta, bem como há centralidades na China, Europa e Leste Asiático, traduzindo em grande complexidade essa estrutura de comunicação global.

No Brasil, o ingresso destes se dá por meio de vários pontos de entrada, sendo Salvador e Fortaleza no Nordeste, Rio de Janeiro e Santos no Sudeste. Assim, com base em informações divulgadas pela Telegeography $(2014)^{11}$, bem como no Quadro 9, é possível verificar a presença do cabo submarino denominado Atlantis-2, com entrada em Fortaleza. O Atlantis-2 é de propriedade da Embratel e de outras empresas com atuação internacional, sendo o mais antigo cabo em operação no momento, datando de 2000 sua entrada em serviço, fazendo ligação com a América Latina, África e Europa.

11 Disponível em: <www.submarinecablemap.com/\#/>. Acesso em: 21 out. 2015. 


\begin{tabular}{|c|c|c|c|}
\hline 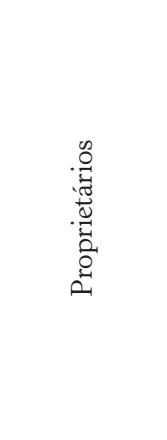 & 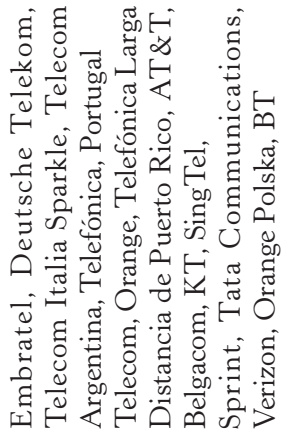 & $\begin{array}{l}m \\
\stackrel{m}{\mathcal{U}} \\
⿶\end{array}$ & 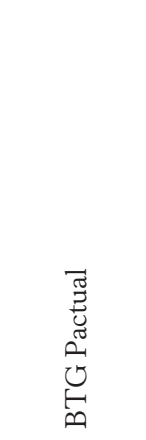 \\
\hline 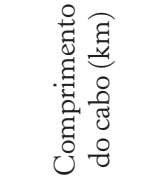 & $\begin{array}{l}8 \\
i n \\
\infty\end{array}$ & 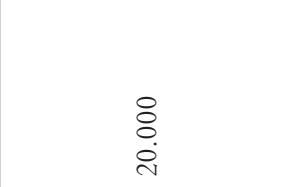 & $\begin{array}{l}\stackrel{P}{N} \\
\stackrel{1}{2} \\
\stackrel{\sim}{N}\end{array}$ \\
\hline 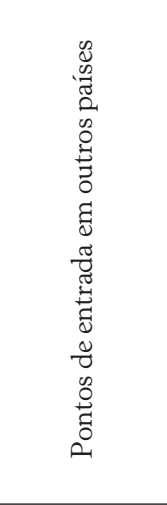 & 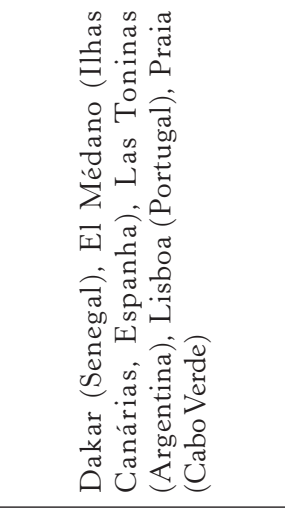 & 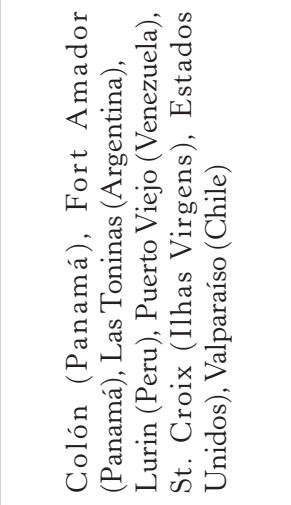 & 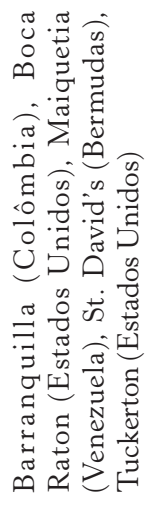 \\
\hline 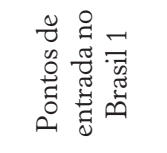 & 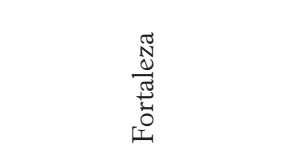 & 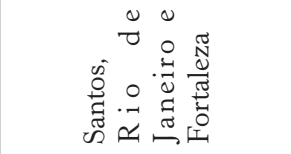 & 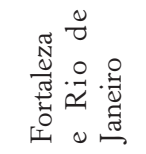 \\
\hline 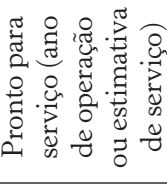 & $\begin{array}{l}\stackrel{8}{8} \\
\stackrel{0}{ } \\
\text { i }\end{array}$ & $\begin{array}{l}8 \\
\stackrel{8}{0} \\
\text { ن }\end{array}$ & $\begin{array}{l}8 \\
8 \\
i \\
ن\end{array}$ \\
\hline 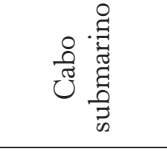 & 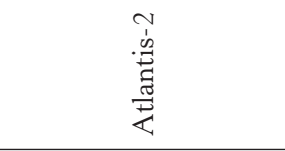 & 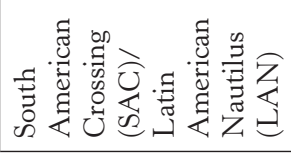 & 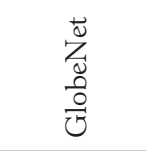 \\
\hline
\end{tabular}




\begin{tabular}{|c|c|c|}
\hline 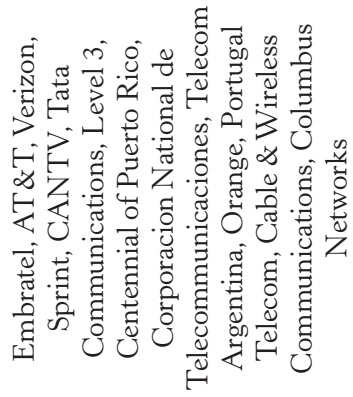 & 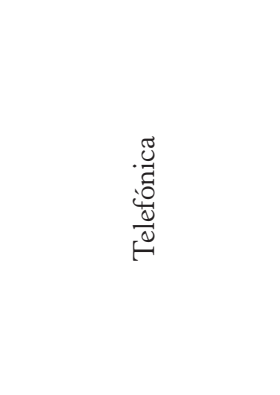 & 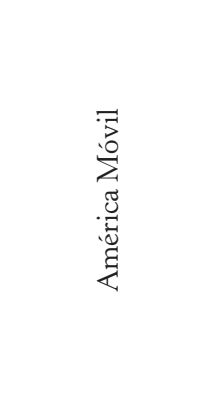 \\
\hline$\underset{\infty}{\infty}$ & $\begin{array}{l}8 \\
8 \\
\stackrel{2}{2} \\
\sim\end{array}$ & $\begin{array}{l}\stackrel{2}{\circ} \\
\infty \\
\stackrel{1}{-}\end{array}$ \\
\hline 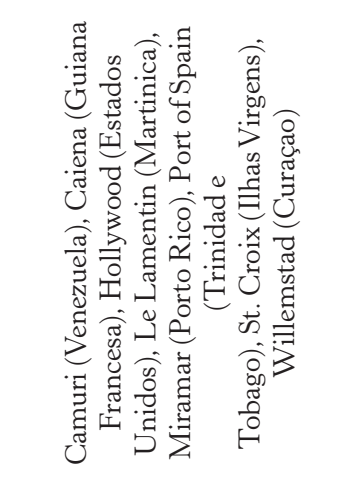 & 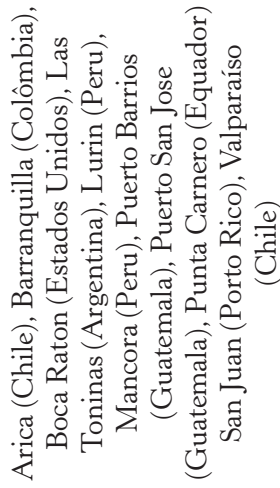 & 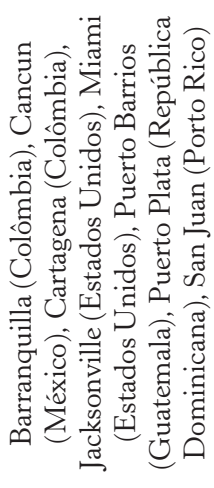 \\
\hline 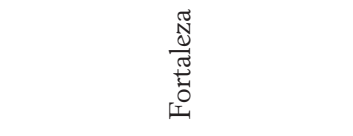 & 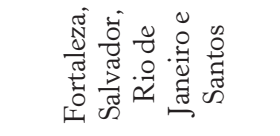 & 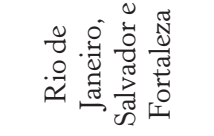 \\
\hline $\begin{array}{l}8 \\
8 \\
i \\
ن\end{array}$ & $\begin{array}{l}\overrightarrow{8} \\
\dot{8} \\
i\end{array}$ & $\begin{array}{l}\stackrel{+}{\sigma} \\
\dot{i}\end{array}$ \\
\hline 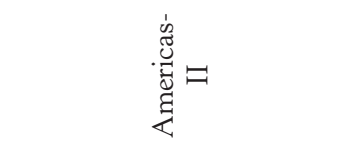 & 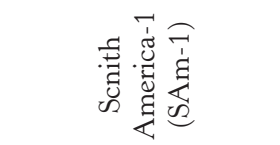 & 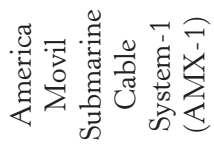 \\
\hline
\end{tabular}


256 PAULO FERNANDO JURADO DA SILVA

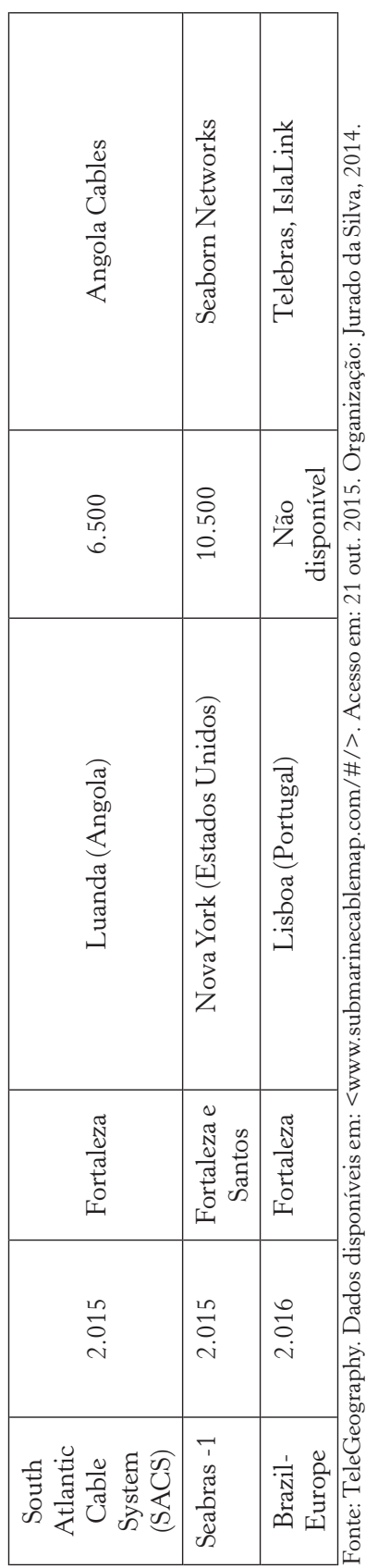


Além deste cabo, há ainda em serviço o South American Crossing (SAC)/Latin American Nautilus (LAN), GlobeNet, Americas-II, South America-1 (SAm-1), América Móvil Submarine Cable System-1 (AMX-1) e em andamento o South Atlantic Cable System (SACS), Seabras - 1 e o Brazil-Europe.

Com isso, cumpre assinalar que cada cabo deste que foi apresentado tem uma extensão própria, ligando diferentes partes do Brasil ao mundo. Alguns têm traçado voltado para a América Latina, outros para a América do Sul, África e Europa, dependendo do grupo de atuação e do interesse do projeto que pode abarcar desde o uso exclusivo para dados e internet, ou mesmo telefonia internacional.

No caso do cabo Brazil-Europe que aparece com essa designação pela TeleGeography o mesmo foi denominado pela Telebrás de JVCo (Joint-Venture Company), sendo uma parceria entre essa e a empresa espanhola IslaLink Submarine Cables, que já tem longa tradição nesse segmento. Segundo a Telebrás ${ }^{12}$, essa é uma empresa que terá a maioria de capital nacional, inclusive com ações de fundos de investimentos específicos, totalizando a soma de 185 milhões de dólares no projeto. Tal iniciativa se deu em razão de questões comerciais e estratégicas com a Europa, conformando um novo canal para transmissão de dados via internet entre o Brasil e seus parceiros estratégicos.

Ademais, vale frisar que o projeto da Telebrás JVCo ganhou força justamente no momento em que há diversas denúncias por parte de Edward Snowden (analista de sistemas que prestou serviços para a agência norte-americana NSA - National Security Agency) de que o órgão de inteligência, para o qual foi contratado, havia feito espionagem de diversos países, governos e empresas - incluindo o Brasil no centro dessas discussões. Tais revelações foram divulgadas em jornais de ampla difusão como The Guardian e Washington Post e em veículos de comunicação das Organizações Globo.

12 Disponível em: < www.telebras.com.br/inst/?p=5272>. Acesso em: 21 out. 2015. 
Nesse cenário, o governo brasileiro agiu por meio da Polícia Federal e de uma Comissão Parlamentar de Inquérito (CPI) para apurar tais denúncias. A CPI, por sua vez, "[...] não conseguiu identificar os responsáveis pela interceptação de dados de brasileiros feita pelo governo dos EUA". ${ }^{13}$ Ademais, o caso ganhou forte repercussão internacionalmente, mobilizando governos e organismos, supostamente vítimas da espionagem, a pedirem explicações do governo estadunidense, como fez a presidenta Dilma Rousseff e a chanceler alemã Angela Merkel; levando a mandatária brasileira, inclusive, a propor uma maior regulação por parte dos Estados para o uso dos serviços de telecomunicações (especialmente internet) no mundo.

Enquanto isso, no governo se discutia o chamado Marco Civil da Internet como proposta apresentada desde 2011, tramitando como Projeto de Lei na Câmara dos Deputados (PL 2126/2011) ${ }^{14}$ e desde março de 2014 submetido ao Senado, sendo aprovado nessa casa na noite de 22 de abril de 2014. Tal aprovação aconteceu a tempo de servir como exemplo e modelo no evento NETmundial, realizado em São Paulo, que tratou da governança da internet em âmbito internacional, em uma carta de intenções e princípios. Foi também durante a realização desse evento, em 23 de abril de 2014, que a presidenta Dilma sancionou o Marco Civil da Internet no Brasil, abrindo espaço para o diálogo com diversas autoridades estrangeiras sobre o assunto.

O objetivo do projeto do Marco Civil é, portanto, regular o uso da internet no Brasil, disciplinando o setor e conferindo a ele determinada normatividade, o que equivale, grosso modo, a uma "Constituição da Internet no Brasil". Os debates foram feitos no governo, na sociedade civil, na comunidade técnica e nas universi-

13 Disponível em: <www1.folha.uol.com.br/mundo/2014/04/1437177-cpifracassa-na-identificacao-dos-responsaveis-pela-espionagem-dos-eua-a-brasileiros.shtml>. Acesso em: 8 abr. 2015.

14 Informação apresentada no sítio da Câmara dos Deputados. Disponível em: <www.camara.gov.br/proposicoesWeb/fichadetramitacao?idProposi$\mathrm{cao}=517255>$. Acesso em: 21 out. 2015. 
dades, tendo como órgão de representação especial para o assunto o Comitê Gestor da Internet (CGI.br), com sede em São Paulo, em um modelo baseado na "governança multissetorial". Tal modelo é assim designado porque acolheu de forma participativa, e em um espaço aberto e público, diversos setores da sociedade que opinaram e compartilharam argumentos sobre a regulação da questão no país.

O marco envolveu a discussão de responsabilidade de provedores de internet e dos usuários, marketing dirigido, armazenamento de dados, exclusão de conteúdo, privacidade, sigilo e neutralidade da rede, gerando grandes discussões na sociedade civil, nos meios de comunicação, redes sociais, provedores de internet, empresas, nas operadoras de serviços de telecomunicações e, principalmente, na grande mídia capitaneada pela televisão. A proposta em si não é simplesmente um projeto de lei, mas uma "carta de direitos e deveres" que contou com a participação dos cidadãos e diversos organismos na construção do conteúdo do documento, em um processo colaborativo via web para se tornar uma referência mundial, a favor da "neutralidade", da "privacidade" e da "liberdade de expressão" no uso da rede.

Com isso, a pauta da segurança do usuário de internet e da privacidade na comunicação tem ganhado espaço nesse debate extremamente importante. Nessa discussão, também se faz presente a questão do armazenamento de dados dos usuários, tráfego de acessos e o compromisso dos provedores em mantê-los em segurança, livre de invasões e ataques criminosos. Desse modo, se pode escrever de uma responsabilidade compartilhada entre usuários, empresas provedoras e governo no uso da internet no país.

Para tanto, as empresas acabam contando com Centros de Processamento de Dados, mais comumente conhecidos como Data Centers, abrigando diversos servidores e bancos de dados em quantidade e qualidade com vistas ao armazenamento, proteção e processamento de dados. O Mapa 11 demonstra, nesse contexto, a localização dos Data Centers no país. Nele, observa-se uma maior 
presença destes centros de processamento de dados em Estados da chamada Região Concentrada, embora também haja a sua presença em algumas capitais do Nordeste, Centro-Oeste e Norte do país.

Tal mapa, somado a outras ilustrações que foram apresentadas durante a construção desta obra, reflete um Brasil desigual, rico, pobre e contraditório. Assim, há determinadas áreas e regiões plenamente integradas às demandas e usos corporativos e outros pedaços do território alheios aos grandes fluxos de capitais e às redes técnicas de poder.

Pode-se, portanto, falar de um território bem equipado, em termos técnicos de circulação e acesso à informação, vinculada às demandas do capital corporativo, e de pedaços do território em que esse tipo de informação e mensagem são vistos em outro patamar. Há, nesse sentido, um uso corporativo do território pleno em algumas partes e um uso corporativo com menor agressividade técnica e competitiva, em outras parcelas territoriais.

Com isso, para representar a concentração econômica decorrente do processo de urbanização, industrialização e inserção produtiva da informação na economia no Brasil é plausível identificar no território brasileiro uma região concentrada, como escreveram Santos e Ribeiro (1979), bem como Santos e Silveira (2006). Trata-se, nesse sentido, de uma forma de regionalizar o território, sobretudo, a partir da análise da densidade técnica, científica, informacional e econômica do país, respeitando os limites municipais e os limites estaduais.

Há, entretanto, outras formas de regionalização que foram levadas a cabo por diferentes autores, como Pedro Pinchas Geiger (1969), que dividia o território em três regiões distintas com base na industrialização, aspectos naturais e nas mudanças ocorridas na urbanização daquele período, ou seja, Amazônia, Centro Sul e Nordeste. Tal regionalização não levava em conta o respeito aos limites estaduais, por exemplo, e se baseava na ideia de complexos geoeconômicos. 


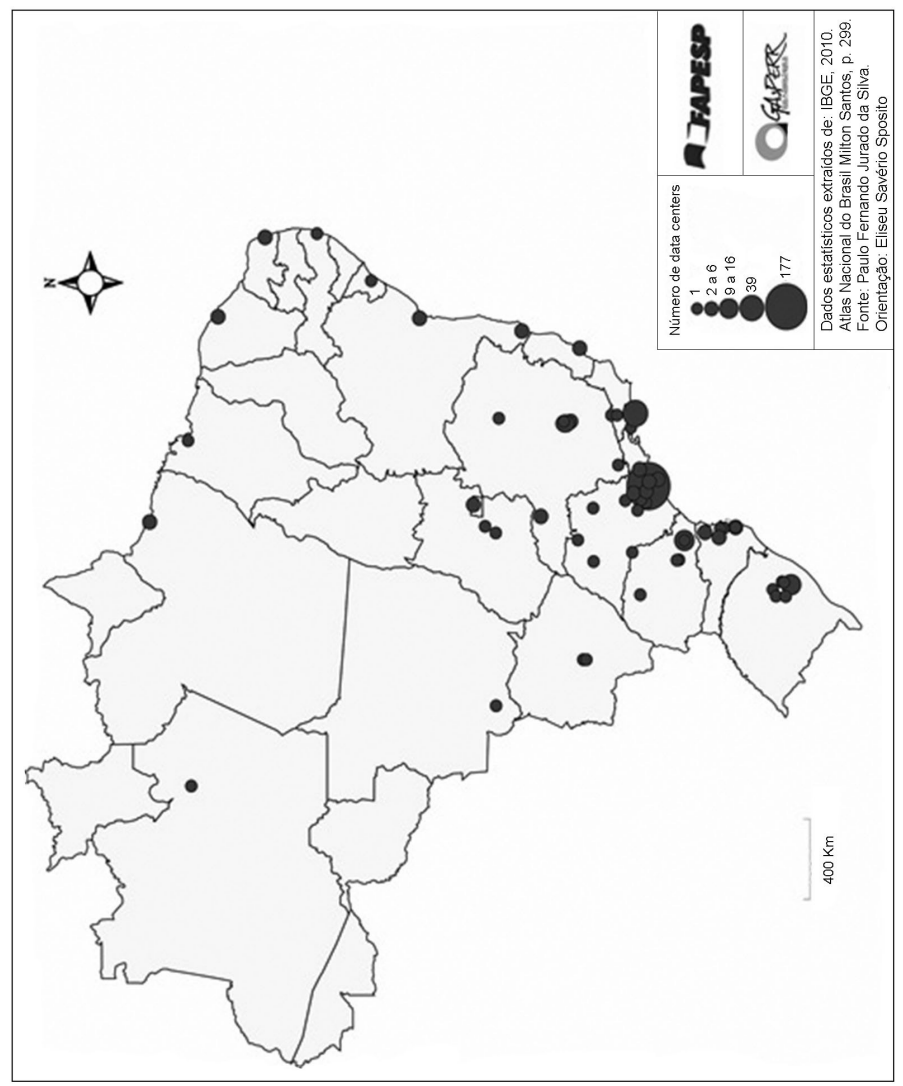

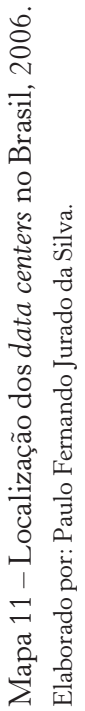


Nesse sentido, é preciso ter bem claro que: "As regiões também podem ser estudadas a partir de uma problemática que parta do reconhecimento daquelas funções que as inserem na atual divisão territorial do trabalho [...]" (Silveira, 1999a, p.72). Trata-se, consequentemente, de escrever sobre regiões integradas à economia internacional e outras com menor grau de inserção; regiões com forte capacidade de telecomandar e outras com menor potencial; submissas à tirania do capital e dos territórios informados corporativamente, tecnicamente, financeiramente, mecanicamente, eletronicamente, cientificamente e modernamente inovadores.

Aqui, como se trata de um trabalho que foca seus esforços no estudo das telecomunicações, é possível, com base nas leituras e argumentações trabalhadas, descrever ao menos em 7 pontos do território nacional: a presença densa de urbanização, produto interno bruno, técnica, ciência, informação, máquinas, empresas (industriais, de serviços e do comércio), mídia, provedores, empregos, carros, aviões, ferrovias e infovias. Com isso, pode-se argumentar sobre uma regionalização do território nacional fundamentada no grau de: modernização tecnológica, inovação, produção industrial, importância na rede urbana e na presença plena de serviços de telecomunicações banais e complexos, que assumem as distintas economias municipais, metropolitanas e estaduais.

Para tanto, o ponto de partida para a montagem conceitual de representação dessa expressão geográfica das telecomunicações no território é a abordagem areal e reticular. Com isso, a discussão areal é feita a partir da análise e seleção de determinados aglomerados urbanos e, ao mesmo tempo, reticular ao relacionar a ligação técnica material (infraestrutural) e imaterial (informacional) dessas áreas por meio de redes técnicas avançadas de fibras ópticas, data centers, satélites no ritmo da circulação de ideias em ondas; na pulsação e no movimento de um país que está em constante transformação espacial e social, ou seja, socioespacialmente. Assim, tal expressão geográfica de síntese é mais bem visualizada em termos espaciais no Mapa 12. 
Por conseguinte, os aglomerados elegidos para compor essa área concentrada abarcam a dimensão de cidades modernas e de um espaço rural no entorno dinâmico e técnico, para atender as demandas de uma sociedade em transformação. São, portanto, aglomerados da técnica, frutos da ciência, da informação, da urbanização, industrialização, dos serviços e do comércio avançado, em ampla relação com o plano nacional e com interações fortes com o estrangeiro. Nesse caso, tais espaços são, especialmente, metrópoles que coordenam uma densa rede de relações territoriais e, desse modo, apoiamo-nos, sobretudo, em Ascher (1995) para fundamentar tal cenário quando argumentou que:

Les métropoles concentrent aussi de façon croissante les actvités stratégiques, identifiés par des fonctions (information, recherche, recherche-industrie, commerce de gros, commercial-industriel), des secteurs d'activité (presse-édition, études conseil et assistance, administration publique, recherche et enseignement supérieur, industrie, commerce interindustriel) et des professions (chefs d'entreprises, cadres, journalistes, chercheurs, ingénieurs, architectes, médecins, cadres commerciaux, etc.) [...]. (1995, p.22).

Assim, é preciso ter em mente que não se trata de identificar somente metrópoles com função de telecomandar no território brasileiro, mas de observar, sobretudo, a proximidade em que se encontram no tecido de relações econômicas e políticas, no sentido de observar a área que possui a maior carga de densidade técnica do país e um alinhamento estratégico, na produção da normatização, regulação, circulação e gestão territorial corporativa e estatal. Por abstração genérica, denominaremos a união desses pontos de dinamicidade econômica e de forte capacidade de telecomando, resultante desse uso corporativo do território de $\Psi$ (Psi) geográfico, que é a vigésima terceira letra do alfabeto grego. 


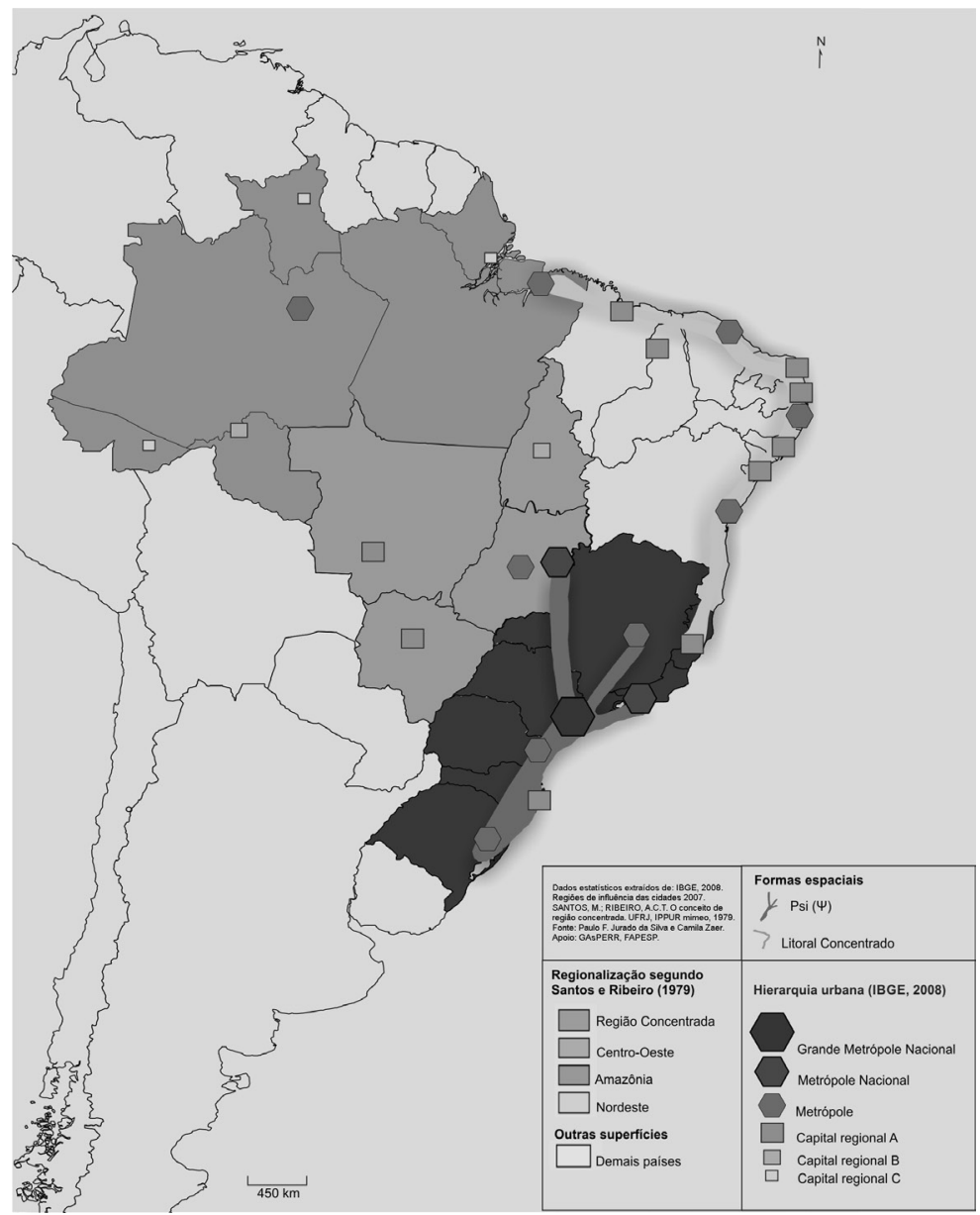

Mapa 12 - O Psi no território brasileiro.

Elaborado por: Paulo Fernando Jurado da Silva.

Tal $\Psi$ é, portanto, a forma espacial que ganha a articulação topológica do território das telecomunicações e do poder econômico no Brasil, como demonstra o Mapa 12. Entretanto, é preciso ressaltar que se trata de um Psi imperfeito, quando analisado a continuidade territorial do fenômeno, mas que tende a se tornar mais claro quando visualizado a partir da integração imaterial que promove os 
serviços de telecomunicações no território, unindo essa morfologia técnica a partir de diversas redes e conformando a área que concentra maior densidade técnica e econômica do país. Nesse sentido, o Psi Geográfico da Técnica e das Telecomunicações ou Tridente da Globalização territorial seria composto por distintas unidades espaciais de telecomando, incluindo a:

- Região Metropolitana de Porto Alegre (Grande Porto Alegre): inserida no estado mais austral do país, ou seja, o Rio Grande do Sul, que é a porta de entrada para o Mercosul, que, por sua vez, reúne mercados do Cone Sul como Paraguai, Argentina e Uruguai. Mantém importante fatia da produção industrial do país, a exemplo dos segmentos químicos, universidades, centros de pesquisa e no setor de tecnologia da informação é sede permanente do Fórum Internacional Software Livre. Nessa região, cujo tecido urbano e desenvolvimento econômico é comandado por Porto Alegre, há ainda as sedes de diversas corporações e atividades econômicas, a exemplo da produção de automóveis em Gravataí, com a Chevrolet, e em Guaíba, com o projeto da Foton, de capital chinês, voltado à produção de caminhões.

- Grande Florianópolis e adjacências regionais: reunindo a área territorial da Grande Florianópolis e, na adjacência, a mesorregião do Itajaí (especialmente Itajaí e Blumenau) e o Nordeste de Santa Catarina (destaque para Joinville) é uma das áreas com maior industrialização do país. Florianópolis, por exemplo, apresenta diversas empresas do segmento de produção de softwares e tecnologia, contando com vários centros de tecnologia e parcerias entre universidades e empresas para a produção de tecnologias e incubadoras de negócios. Itajaí, depois de Santos, é o maior porto com movimentação de containers do Brasil, polo de produção naval e ponto de exportação de parte da indústria automobilística e têxtil nacional. Blumenau, por sua vez, destaca-se na produção metalúrgica, mecânica e elétrica, mas, sobretudo na produção de softwares, sendo a sede do Vale do Software no Sul do país, com incubadora específica na área. Já Joinville é o município com maior industrialização de Santa Catarina, com 
destaque para os segmentos químico, mecânico, plástico, têxtil e também a produção de softwares; e ainda no Nordeste Catarinense há Araquari, que mesmo não sendo um grande centro, em termos demográficos, acolhe o projeto de instalação da fábrica de automóveis da BMW no Brasil.

- Região metropolitana de Curitiba (Grande Curitiba): nessa porção do território paranaense estão concentrados os principais investimentos na área de inovação, centros de tecnologias e as importantes universidades do Estado. Destacam-se Araucária com a sede da REPAR (Refinaria Presidente Getúlio Vargas); São José dos Pinhais, por meio do Complexo Ayrton Senna com as montadoras da aliança Renault-Nissan e também, em outra extensão, a Volkswagen. Já no plano da inovação, Curitiba possui diversas iniciativas, com destaque para o centro de inovação da Microsoft, no contexto da Cidade Industrial do Instituto de Tecnologia do Paraná (Tecpar) com o desenvolvimento de diversos projetos, na área de inovação e tecnologia. Além disso, encontra-se a sede do grupo Positivo Informática, que é uma das maiores companhias produtoras de computadores do Brasil, e a Global Village Telecom (GVT), que opera serviços de telecomunicações como internet, televisão por assinatura e telefonia.

- Macrometrópole paulista ${ }^{15}$ : composta por um tecido urbano bastante complexo e denso, é o maior polo econômico, financeiro, industrial e informacional do país. São Paulo abriga a sede de diversas grandes corporações de capital nacional e internacional em operação no Brasil; bolsa de valores; universidades com projeção internacional como a Universidade de São Paulo (USP); centros de pesquisa; grandes grupos de comunicação como Globo São Paulo, Record, SBT e Bandeirantes; jornais de circulação nacional a exemplo de Folha de S.Paulo e Estadão; provedores como UOL; operadoras de serviços de tele-

15 Designação apoiada na Emplasa - Empresa Paulista de Planejamento Metropolitano. Disponível em: <www.emplasa.sp.gov.br/newsletter/maio/ interno/caracteristicas_objetivos.asp>. Acesso em: 21 out. 2015. 
comunicações como a NET e a Vivo. Nesse sentido, é preciso ressaltar que essa macrometrópole engloba, além da Grande São Paulo, regiões como Campinas, Baixada Santista e Vale do Paraíba e Litoral Norte. Para a Emplasa - Empresa Paulista de Planejamento Metropolitano - essa região é formada por "[...] 173 municípios que concentravam, em 2010, 73,3\% do total da população paulista, $83,4 \%$ do Produto Interno Bruto (PIB) estadual e 27,6\% do PIB brasileiro -, além de abrigarem cerca de $50 \%$ da área urbanizada do Estado". ${ }^{16}$ Nessa região, há o maior porto do Brasil, localizado em Santos, grandes refinarias como a de Paulínia, a Embraer, que se dedica a produção de aviões e o Instituto Nacional de Pesquisas Espaciais (INPE) em São José dos Campos, a operadora de serviços de telecomunicações Sky em Santana do Parnaíba, o Centro de Pesquisa e Desenvolvimento em Telecomunicações (CPqD), Toyota, Honda, Samsung, Motorola, Bombardier na região de Campinas, entre tantas outras companhias reconhecidas mundialmente, seja de capital nacional ou internacional.

- Região Metropolitana do Rio de Janeiro (Grande Rio): é o segundo polo econômico mais dinâmico do país, reunindo um parque industrial diversificado com refinarias de petróleo, indústria naval, petroquímicas, metalúrgica, químicas, siderúrgicas, entre tantas outras. Tal região conta com os maiores estaleiros do país e é sede de empresas de telecomunicações como Oi e Embratel, além do maior grupo de comunicação televisiva do país: a TV Globo, que é vinculada às Organizações Globo, que possuem em sua estrutura uma densa cadeia de canais de televisão paga, jornais, provedor de internet, revistas etc. Nessa região metropolitana, somam-se ainda uma lista bastante extensa de empresas importantes como Petrobras, Shell, Chevron etc. Mas não são só empresas de capital privado, misto e estatal que garantem presença nesse território, como também o go-

16 Citação extraída de Emplasa. Disponível em: <www.emplasa.sp.gov.br/newsletter/maio/interno/caracteristicas_objetivos.asp>. Acesso em: 21 out. 2015. 
verno e suas estruturas de administração. Assim, é o caso de citar o Banco Nacional de Desenvolvimento Econômico e Social (BNDES), Casa da Moeda do Brasil, Comissão de Valores Mobiliários (CVM), Instituto Brasileiro de Geografia e Estatística (IBGE), o Instituto Nacional da Propriedade Industrial (INPI), Eletrobrás e tantos outros órgãos, autarquias, centros de pesquisa e universidades de ponta, como a Universidade Federal do Rio Janeiro (UFRJ).

- Região Metropolitana de Belo Horizonte (Grande Belo Horizonte): inserida no contexto do Estado de Minas Gerais, possui nas atividades industriais segmentos como petroquímico, extrativo mineral, siderurgia, alimentício, metalúrgico etc. A capital Belo Horizonte, somada aos municípios de Betim e Contagem, constitui-se em um dos maiores polos econômicos do Estado, contando com a presença de diversas universidades como a Universidade Federal de Minas Gerais (UFMG) e centros de pesquisa. Belo Horizonte, por sua vez, está entre as capitais do Brasil com maior número populacional, PIB e área de influência. No momento, a biotecnologia, o segmento de softwares e aparelhos eletrônicos são também uma das apostas para o crescimento econômico da região metropolitana. No setor automobilístico, possui em Betim a fábrica da Fiat, que atualmente é a líder de vendas no país.

- Região Integrada de Desenvolvimento do Distrito Federal e Entorno: formada pela capital Brasília que abriga as sedes do executivo, legislativo e judiciário e por alguns núcleos urbanos do entorno, tem na capital seu grande centro econômico, financeiro e político, sendo os centros do entorno dependentes dessa estrutura e, ao mesmo tempo, oferecendo função complementar a esta. Nelba Penna, (2003, p.6), retratando, por exemplo, esse universo desigual e contraditório escreveu que: "Em consequência dos processos de ordenamento de seu território, ocorreu uma intensa expansão da urbanização para a periferia que deu origem à formação da região metropolitana de Brasília [...]” e, nesse sentido, a criação do "[...] chamado Entorno, atualmente 
institucionalizado como Região Integrada de Desenvolvimento do Distrito Federal e Entorno (RIDE)" (Penna, 2003, p.8). Em Brasília estão localizadas diversas sedes de estruturas governamentais, embaixadas, empresas e órgãos de representação estatal. Banco Central, Agência Nacional de Telecomunicações, Universidade de Brasília (UNB), Coordenação de Aperfeiçoamento de Pessoal de Nível Superior, Conselho Nacional de Desenvolvimento Científico e Tecnológico, Instituto Brasileiro de Informação em Ciência e Tecnologia (IBICT), diversos ministérios como o Ministério da Ciência e Tecnologia, entre tantos outros. Além disso, Brasília, nos últimos anos, tem investido consideravelmente no incentivo às empresas produtoras de tecnologia, desenvolvimento de software e segurança eletrônica. Isso porque a capital do país e as estruturas administrativas do governo representam um dos maiores consumidores de tecnologia da informação, com a presença do Parque Tecnológico Capital Digital, que é o data center do Banco do Brasil e da Caixa Econômica Federal, entre tantas outras iniciativas. A Torre de TV Digital de Brasília, apelidada de "Flor do Cerrado" por Oscar Niemeyer, é também símbolo emblemático da capital que se projeta na área de telecomunicações. Brasília é, portanto, o núcleo central por onde se irradia a regulação do setor para todo o país, por meio da Anatel e do Ministério das Comunicações. O Distrito Federal é o espaço que possui maior quantidade de celulares por habitantes no Brasil, conformando a maior teledensidade do país.

Tendo em vista essa realidade plural, desigual e multifacetada é preciso reconhecer que estamos diante de universo técnico bifronte, que reúne a contradição entre o moderno e o não moderno, a pobreza e a riqueza, na interface entre o ligamento e o desligamento, a inclusão e a exclusão. Nesses centros de concentração econômica e técnica não há somente riqueza do ponto de vista econômico, mas há também bolsões de pobreza, desigualdade e injustiça social. 
Há denúncias recorrentes de trabalho análogo à escravidão e trabalho precário, desemprego, poluição ambiental, falta de água e de saneamento, pessoas sem moradias, ocupações irregulares, congestionamento veicular, problemas de transporte público, especulação imobiliária, degradação ambiental, insegurança urbana e tantos outros problemas e males que afligem esses aglomerados e expõe, grosseiramente, a fragmentação e a segregação socioespacial urbana, como causas diretas do desenvolvimento desigual que acirra a luta de classes.

Além disso, é válido frisar que capitais como Recife, Fortaleza, Salvador e Goiás também são relevantes para explicação do Brasil atual, desigual e complexo. Por conseguinte, determinadas capitais do Nordeste somadas a Vitória (ES), igualmente se posicionam territorialmente de modo a desempenhar importante ação na rede urbana, bem como na concentração da técnica, sendo formas crescentes de um território em expansão, com novidades empresariais e soluções de inovação particulares. Trata-se, nitidamente de um "Litoral Concentrado", herdeiro ainda do modelo de colonização portuguesa e que com o passar do tempo foi ganhando diferentes configurações e conotações, mantendo-se, no entanto, como espaço privilegiado para investimentos e inserção da técnica.

Já outras capitais interioranas, como Cuiabá, Campo Grande, Goiânia, Manaus e Belém conservam também certa concentração técnica, mas representam, sobretudo, territórios informados de conteúdo técnico e elos da ligação nacional de um país que se transforma, constantemente.

Manaus, por exemplo, localizada na região amazônica, concentra um importante polo industrial, decorrente das atividades provenientes da Zona Franca de Manaus, que criada desde 1967 e administrada pela Superintendência da Zona Franca de Manaus, reúne especialmente na produção de eletrônicos, como televisões e computadores, seu grande valor de mercado. Desse modo, há um território plenamente integrado às demandas do globalitarismo, do poder corporativo e do telecomando de agentes supranacionais como firmas globais e nacionais, na produção de normatizações locais. 
Para além do Psi ainda há a presença de informação e de densidade técnica em outras partes do território, que, embora não sejam tão concentradas e dominantes, expressam uma boa parcela da realidade dos serviços de telecomunicações no país. Nesses pedaços do território, orbitam ainda centros de polarização intermediários como Londrina, Maringá, Uberlândia, entre outros. Em centros como Londrina e Uberlândia, são as empresas que foram fundadas localmente no setor de telecomunicações que possuem um papel de agir espacialmente histórico, a exemplo da Sercomtel, em Londrina, e da CTBC em Uberlândia e Triângulo Mineiro.

Com isso, é na dimensão das telecomunicações e da técnica no território que se configuram alianças corporativas global, nacional e localmente. Há, por outro lado, uma guerra competitiva entre distintos pedaços do território pela instalação de determinada companhia ou mesmo adoção de práticas complementares entre tais empresas e locais.

O telecomando exercido pelo Psi e também pelo oligopólio das telecomunicações no Brasil é alicerce para a construção de um controle remoto de diferentes porções do território pelo capital privado e corporativo (nacional e internacional), que reúne uma infinidade grande de companhias, setores e organismos interessados em participar da infraestrutura, dos sistemas de movimento, do uso territorial de um país com dimensões continentais, rico, diverso, mas sobretudo desigual e carente de maior distribuição de renda, de educação, saúde e de tantos outros problemas discutidos cotidianamente nas universidades, na mídia e pela população.

Dimensões essas que deveriam compor a cidadania territorial de um país e das pessoas, pois não é o acesso a determinados serviços como telefonia celular, internet e televisão por assinatura que fazem da população mais consciente e menos alienada, pois estes são dados do consumo, do capital, do mundo das mercadorias. Com isso, a realidade é que o território foi preparado técnica e normativamente para ser instrumento de emissão e recepção das demandas da globalização e da internacionalização, em um capitalismo voltado para atender, especialmente, o poder corporativo e também 
as formas não solidárias de competição territorial e de amparo das estruturas de comando das classes hegemônicas.

As marcas, desse modo, entram diretamente no mundo do consumo da população como se comunicassem status, espaços são estandardizados, a televisão passa a ser o grande modelo em que se inspiram milhares de pessoas para comprar moda e objetos técnicos. Objetos que também são disseminados pela internet em milhares de aparelhos celulares e computadores distribuídos no território.

A partir disso, é como se a informação trouxesse à tona, por meio do conjunto de serviços e redes técnicas que as suportam, a promoção da globalização de um dado profundo dos valores das classes dominantes. Por isso, se hoje se fala tanto em liberdade de mercados e liberdade das redes é porque o capital, para se reproduzir ainda mais, precisa circular sem constrangimentos, barreiras espaciais e institucionais.

Por fim, são as ondas da informação de diferentes modos que transmitem a conexão e a desconexão e que ativam ou desativam lugares, compondo normatividade, ordem e poder de determinados agentes, corporações e do Estado. Os territórios são hoje alvo da estratégia de grupos empresariais, da regulação estatal, do telecomando em comunicação com as grandes engrenagens que mantém o sistema capitalista em ação, por meio do poder do controle remoto corporativo dos territórios e das instituições globalmente. 


\section{CONCLUSÃo}

\section{Arrematando ideias ou à Geografia um manifesto}

As telecomunicações como suporte e condição sine qua non do processo de desenvolvimento desigual da sociedade colocam em movimento a informação e a comunicação como elemento essencial da inovação, reprodução e ampliação do capital. Com isso, novos desafios são postos aos governos, sociedade civil e aos estudiosos sobre um tema que está em constante transformação e que é tão caro à agenda das empresas.

Diante desse quadro, é necessário ter em mente que muitos trabalhos irão surgir a respeito do tema das telecomunicações. Assim sendo, é bastante nítido que o presente livro apresentou um caráter focalizado e é um retrato da dimensão do período atual, acelerado e robustamente tirano. Além disso, é claro que muitas reflexões elaboradas precisam ser mais bem elucidadas e retomadas em investigações futuras pelo autor e por outros estudiosos do tema.

A postura teórica adotada de transitar na interface da Filosofia da Técnica (por meio do diálogo epistemológico da questão no âmbito do Pensamento Geográfico) e da Geografia Econômica 
mostrou-se útil à medida que possibilitou um diálogo de campos do conhecimento, mas é igualmente verificável que nesse esforço uma dessas dimensões exploradas possa ter sido mais predominante, em determinados pontos.

Para tanto, é preciso reconhecer que, no Brasil, quebrado o monopólio estatal do setor, foi aplicado um conjunto de medidas legais, dispositivos e normas do ponto de vista da legislação com vistas ao ingresso maciço de capital internacional no setor. O território brasileiro se tornou, portanto, alvo da investida crescente de múltiplos capitais e o uso corporativo do território ganhou cada vez mais a forma de um oligopólio que concentra, além do Market share, investimentos em infraestrutura, clientes, capital e influência, na mídia e na vida banal.

Porém, é importante frisar que as condições de acesso ainda são bastante desiguais, expondo uma topologia geográfica irregular, na distribuição do serviço, bem como no uso corporativo, derivado da ação territorial das companhias que exploram o setor. Além disso, nem toda a população pode usufruir das inovações desse campo, que são postas em funcionamento, cotidianamente, por meio da esfera do consumo, da propaganda e das redes sociais. Não se tem, nesse sentido, uma solidariedade territorial do ponto de vista da difusão corporativa desses serviços e muitas pessoas ainda não têm acesso à educação informacional que as possibilitem conectar-se a esse modo de construção do mundo e da economia flexível.

Além disso, muitas pessoas para ter acesso a determinados serviços de telecomunicação acabam se endividando, já que estas, por sua vez, comprometem uma importante fatia de seus salários com outros serviços a exemplo de gás, eletricidade, água, bem como alimentação, moradia, transporte e medicamentos.

Corporativamente, na América Latina, dois grupos sobressaem-se na área de telecomunicações: a América Móvil do México e a Telefónica da Espanha. A América Móvil, por exemplo, vai além da América Latina para operar nos Estados Unidos e a Telefónica mantém igualmente foco na Europa, operando em países como Espanha e Inglaterra, por exemplo. 
As estratégias competitivas são, portanto, abrangentes e envolvem múltiplos cenários de investimento, com regiões que apresentam semelhanças em termos de mercado consumidor, mas também assimetrias do ponto de vista da potencialidade e do grau de consumo dos respectivos mercados internos. Consequentemente, o uso corporativo do território foi vislumbrado a partir da ação do Estado, das estratégias espaciais das companhias do segmento e da forma como a sociedade se apropria desses meios e se desenvolve de forma desigual.

O significado que ganha o setor, desse modo, na sociedade é imenso. As ondas, por sua vez, desse processo desprendem e levam energia na circulação da informação, cujos caminhos e rotas são difundidos, espalhados, disseminados no território de forma multidimensional, trazendo plena recepção, reverberação ou ruído. Leva-se, nessa perspectiva, um modo informacional de vida à terra que agora pode ser vista em todos os ângulos, detalhes, escalas pelos satélites. Embora, haja de se ressaltar que essa transição de uma sociedade industrial para uma pós-industrial e informacional não tenha sido completamente efetuada, dada a magnitude desse processo e assimilação diferenciada dessas transformações, em diversos territórios.

Da cidade ao campo, da indústria ao comércio e aos serviços utilizam-se das telecomunicações, no processo de circulação de mercadorias, produção de comunicação, negociação, abastecimento etc. Tal setor configura-se, portanto, como insumo fundamental da instância de produção da mais-valia, em escala planetária. Assim, ao mesmo tempo em que se constitui uma visão global e consciente dessas transformações no mundo, também se aliena, distanciando a população do poder e da revolução informacional, como liberdade, que passa a ser vista, no momento, como utopia, pois não é apropriada como potência do vir a ser, permanecendo em estado de latência.

Na realidade, enquanto um pequeno grupo de empresas atua no plano nacional, concorrendo pelo uso do território, em grande parte das cidades pequenas que compõem o fato urbano do país há uma 
situação de monopólio, ou quando no máximo duopólio. Lógicas estas que em tese não foram previstas de forma clara no leilão do Sistema Telebrás e que encontram no período atual um fato confirmado, na expressão geográfica dos eventos que se acumulam, ao longo do tempo.

Há, nesses termos, duas estratégias de ação das companhias no uso do território: a justaposição e a sobreposição. Enquanto a sobreposição se refere às concessionárias, no sentido de que se utilizam da estrutura da Telebrás, pretérita, para operarem no território, as permissionárias e autorizadas se justapõem territorialmente de modo a não perturbarem com forte impacto o mercado.

Nesse cenário, é preciso ressaltar que a televisão por assinatura como recurso da televisão segmentada revelou-se crescentemente utilizada pelos brasileiros, mas também se buscou demonstrar os acordos firmados entre companhias nacionais e internacionais, a formação de alianças estratégicas de fomento ao benefício mútuo das corporações e que servem, em última instância, de apoio à globalização e ao mundo do consumo.

A telefonia celular, por sua vez, está inserida no mesmo arranjo de grupos dominantes, pertencentes à classe da TV paga. Nela, está inserida a concorrência pelo maior número de clientes, acessos e aparelhos, bem como a possibilidade de integração da televisão paga, da telefonia e da internet em um único objeto técnico que pode ser facilmente manuseado, em qualquer lugar que exista sinal para isso.

Já a internet como maior rede das redes técnicas atuais representa, em essência, espaço para construção e também regulação normativa. O Marco Civil da Internet no Brasil e as diversas leis e mecanismos de controle existentes no mundo fazem dessa rede uma arena para pautas e disputas ideológicas, culturais e de mercado, mas também de integração e desintegração.

Enquanto isso, no território, diversas redes técnicas de fibra óptica de apoio e suporte aos serviços foram construídas, servindo de base para a engenharia da circulação e da técnica, no avanço da informação dos sistemas de movimento. No espaço, as marcas 
também da produção territorial corporativa são marcadas pela exploração de diversos satélites, com licença para operação no Brasil, apoiados e mantidos pela abertura do setor ao poder privado.

A partir dessas diversas discussões, até se tratou de uma nova regionalização para a área que apresenta maior concentração de densidade técnica do país, quando foi abordado o Psi geográfico, no contexto das transformações e do movimento de força e poder construído, historicamente e territorialmente, na produção da integração e do comando/telecomando nacional. Evidente que essa é uma leitura bastante geral de uma forma espacial que ganha o fenômeno, ora em tela, e que é, ao mesmo tempo, um processo e uma dinâmica que se encontra em curso, resultante de múltiplas entradas e também de contradição, desigualdade, sínteses e assimetrias.

Por isso, reconhece-se que o tema das telecomunicações na Geografia é vasto, apresentando diversos planos de interfaces com outras ciências. Atualmente, é incoerente conceber uma análise mais aprofundada da sociedade sem levar em conta o papel que a informação assume, bem como a forma como ela é produzida e apropriada territorialmente, trazendo, por conseguinte, o debate de diversas ideias, conceitos e noções para esse campo de discussão como: sociedade da informação, economia informacional, era da informação, redes técnicas, uso corporativo do território e transformações socioespaciais.

Não há dúvida, porém, que as telecomunicações e os serviços derivados desse setor tenham causado sensível impacto nas condições de organização da sociedade brasileira e internacional ao possibilitarem a quebra de barreiras espaciais que antes inviabilizavam a comunicação, particularmente, em regiões mais remotas do globo. Também, por outro lado, é preciso reconhecer que esse insumo tão essencial à dinâmica de acumulação flexível do capital não é absorvido ou mesmo apropriado e consumido por toda a sociedade de forma igualitária. Do deserto à Antártida, das planícies às montanhas, da terra aos céus o espaço foi ocupado pela densidade técnica das telecomunicações e da informação, bem como por novas formas de regulação e normatização territorial, mas também, ao mesmo 
tempo, promovendo uma inserção desigual no espaço com pontos de concentração, rarefação e ausência de sinal.

Os Estados são, nessa perspectiva, cada vez mais porta-vozes das grandes corporações e de interesses internacionais, na medida em que adaptam suas leis, tornando-as flexíveis aos interesses do capital privado, em nome de determinada regulação. Há, portanto, uma inteligência universal técnica, presidida pelas grandes empresas que dominam os mercados e dão ao território a materialidade do uso corporativo e, consequentemente:

[...] Apesar das sugestões pós-modernas, a que tantos especialistas se rendem, o território continua sendo uma realidade atuante (M. Santos e M. L. Silveira, 1997), ainda que o Estado Nacional, igualmente sobrevivente tenha mudado de figura e de definição segundo os países [...]. (Santos; Silveira, 2006, p.256-257)

Nessa globalização, os serviços de telecomunicações e a grande mídia representam uma onda favorável a esse movimento como um dado da técnica, do capital internacional, com a cobertura do planeta, no qual a informação circula, instantaneamente, e os lugares agem como emissores e receptores de um telecomando de poder no Brasil e no mundo. Nesse contexto, há novas formas de poder e normatização territorial, uma vez que ninguém e muito menos governos e empresas podem exigir das pessoas que se comuniquem por meio de uma forma única e exclusiva, isto é, pela via técnica eletrônica, virtual, robotizada, normatizada e codificada.

Há que se reivindicar, em primeira instância, o direito territorial e à liberdade de expressão, mas também aos direitos civis, políticos, econômicos, sociais, culturais, ambientais, entre tantos outros. É necessário, entretanto, deixar bem claro que o mundo e nem todas as pessoas aceitam passivamente a dominação e o poder que é imposto pelas instâncias da técnica e dos negócios. Há valores que não podem ser considerados como bens de mercado e estes são requeridos cotidianamente nas ruas e no campo, como o direito à vida, à dignidade, ao respeito e à justiça. 
Nesse sentido, se aposta nesse trabalho que a conclusão também tem de trazer algo novo não só reforçando o que já foi dito anteriormente, ou mesmo amarrando as principais ideias. ${ }^{1}$ Para tanto, temos o dever e o compromisso de afirmar o que se falta no Brasil do território usado corporativamente é a cidadania territorial e técnica e o que sobra é competitividade territorial corporativa, regulada pelo Estado. Trata-se, nesse sentido, não só de arrematar ideias e concluir o pensamento, mas de trazer para a pauta de discussão um manifesto à Geografia e à sociedade, reivindicando o território não como instância do consumo, mas como suporte físico e social, meio, condição e fim da construção da solidariedade, justiça, do habitar, comunicar e do viver em todas as suas dimensões.

Nesses termos, pensar em cidadania também é refletir sobre uma solidariedade territorial que permita a inclusão das pessoas como meio emancipador de um movimento que leve em conta demandas sociais reais e não única e exclusivamente a pauta de um grupo seleto de pessoas e empresas controladoras de recursos, inovação, comunicação e produção territorial da informação e da desinformação, no uso e desuso da conquista dos pedaços do território que compõe o universo fragmentado de uma realidade em construção como utopia e matéria.

Assim, se pode escrever de uma divisão territorial do trabalho da informação, composta por um Psi que reúne a concentração e o telecomando, a integração e a desintegração, a algema e a chave para a liberdade. Coordenando ordens, tal forma e processo da globalização se encontra em constante transformação, mas também trazendo aos estudiosos do tema, novas reflexões acerca das cargas de densidade técnica, inseridas territorialmente, bem como na produção de uma sociedade desigual e polarizada pelo consumo material.

O que se advoga, então, é a luta por uma sociedade mais justa, politicamente consciente e informada e, por outro lado, mais igual,

1 Tal postura foi estimulada e apoiada por María Laura Silveira da Universidad de Buenos Aires, em março de 2014, quando foram realizados vários debates e reflexões, nessa instituição. 
segura, protegida e com recursos técnicos e intelectuais suficientes para satisfazer suas necessidades mais básicas e complexas, para criar e inovar. Estamos escrevendo, então, do Brasil real e de um Brasil do vir a ser, na contradição do presente que reúne passado e futuro na concretização de um hoje que inspira desafios e a expressão geográfica do tamanho de um continente. Não se trata de encarar essa proposta como um mero pastiche, trata-se de uma revolução que precisa ser feita em diversos campos da sociedade, da técnica, da ciência e da informação.

A ideia de futuro é, portanto, um dado do novo que acompanha o presente e não se olvida do passado. Ademais, para vencer a miséria da organização capitalista é preciso de sonhos, mas também de capacidade para superar os desafios que estão postos em uma agenda de desenvolvimento em construção. Os fundamentalismos econômicos e políticos não servem para nada, senão para levar a sociedade para um cenário de destruição, vigilância, violência, opressão e tirania.

O fato é que essa grande transição, mudança, transformação para a qual caminha a sociedade pós-industrial causa grande apreensão aos governos, às empresas e às pessoas. Há um caminho de injustiça, alienação, engano, escravidão, miséria, precarização, escassez, morte e violência; e outro da liberdade, da cidadania, da transformação da humanidade a favor de uma consciência universal a favor da justiça e da técnica como facilitadora da solidariedade e, ao mesmo tempo, da igualdade de condições, oportunidades e do bem-estar social e ambiental. Ficamos, portanto, com a opção de vislumbrar um dia ainda esse caminho por meio da segunda opção, traduzindo-se na esperança científica de elaborar uma geografia da liberdade que entenda o ser humano em sua existência, na relação que estabelece diretamente com o Cosmos.

À Geografia cabe, no momento, um papel essencial, que é informar e denunciar o caráter exploratório do território, apropriado, comunicado e eletronicamente, unido à esfera de influência corporativa do território que não é só poder, mas também limite, fronteira; na produção do lugar e na imersão do cotidiano, banal e 
transitório. Não se tem, nessa perspectiva, uma posição neutra da realidade, mas, assume-se o caráter político, social, econômico que a Geografia poderá produzir como ciência consciente a favor da transformação técnica e do modelo de produção a qual nos circunscrevemos, tanto nos trabalhos mais teóricos, quanto práticos e de planejamento. A realidade não pode ser, dessa forma, fragmentada, mas ser encarada por meio de uma visão de totalidade dos fenômenos e eventos estudados. A Geografia tem, assim, de contribuir, no presente, para a construção de um vir a ser mais justo, não se tornando refém da técnica e muito menos uma admiradora passiva e incondicional dessa. 


\section{REFERÊNCIAS}

ABRANET. Informações sobre a internet no Brasil. Disponível em: $<$ http://ww.abranet.org.br>. Acesso em: 28 out. 2015.

ABTA. Informações sobre televisão por assinatura no Brasil. Disponível em: <http://www.abta.org.br/historico.asp>. Acesso em: 28 out. 2015.

. Dados do setor. Disponível em: <http://www.abta.org.br/dados_ do_setor.asp >. Acesso em: 28 out. 2015.

AEB. Satélites de comunicações serão parte do programa espacial brasileiro. Disponível em: <http://www.aeb.gov.br/2011/09/satelites-de-comunicacoes-serao-parte-do-programa-espacial-brasileiro-2/>. Acesso em: 28 out. 2015.

ALEXA. Top sites in Brazil. Disponível em <http://www.alexa.com/ topsites/countries/BR>. Acesso em: 28 out. 2015.

ALGAR TELECOM. História. Disponível em: < http://www.algartelecom.com.br/section.do?CodSec=13952>. Disponível em: 28 out. 2015.

AMÉRICA MÓVIL. Subsidiaries \& Affiliates. Disponível em: <http:// www.americamovil.com/amx/about/footprint? $\mathrm{p}=1>$. Acesso em: 28 out. 2015.

ANATEL. Informações sobre telefonia celular no Brasil. Disponível em: $<$ http://sistemas.anatel.gov.br/SMP/Administracao/Consulta/ AcessosEmpresaGrupo/tela8.asp>. Acesso em: 28 out. 2015.

Informações sobre televisão por assinatura no Brasil. Disponível em: <http://www.anatel.gov.br/hotsites/conheca_Brasil_SATVA/ 
default .asp ? nomeCanal $=$ TVpor Assinatura\&codigoVisao $=5 \& \mathrm{~s}$ ite $=1>$. Acesso em: 28 out. 2015.

Panorama dos serviços de TV por assinatura. 49. ed. 2011. Disponível em: <http://www.anatel.gov.br/Portal/verificaDocumentos $/$ documento.asp? numeroPublicacao $=278907 \&$ pub $=$ original $\&$ filtro $=1 \&$ documentoPath=278907.pdf $>$. Acesso em: 28 out. 2015.

Atribuiçõos. Disponível em : <http://www.anatel.gov.br/Portal/ exibirPortalInternet.do>. Acesso em: 28 out. 2015.

. Endereços e formas de contatos. Disponível em: $<\mathrm{http}: / /$ www.anatel.gov.br/hotsites/Anatel_nos_Estados/endereços_da_anatel_inter. htm>. Acesso em: 28 out. 2015.

Resolução n. 576, de 31 de outubro de 2011. Disponível em: $<$ http://legislacao.anatel.gov.br/resolucoes/26-2011/69-resolucao-576>. Acesso em: 28 out. 2015.

Anatel divulga, em São Paulo, resultados da pesquisa de satisfação dos usuários. Disponível em: <http://www.anatel.gov.br/Portal/exibirPortalNoticias.do acao $=$ carregaNoticia $\&$ codigo $=28725>$. Acesso em: 28 out. 2015.

Disponível em: <http://www.anatel.gov.br/Portal/verificaDocumentos $/$ documento.asp? numeroPublicacao $=286619 \&$ assunto Publicacao $=$ MAPA $\% 20$ DE $\% 20$ COMPETI $\%$ C7\%C3O\%20DO $\% 20$ SMP\&caminhoRel=Cidadao-Telefonia\%20M\%F3vel-Dados $\% 20$ do\%20SMP\&filtro=1\&documentoPath=286619.pdf $>$. Acesso em: 28 out. 2015.

ARANHA P.M. Ciência e território: engenheiros militares e saber geográfico na Comissão Rondon (1907-1915). In : XIV ENCONTRO NACIONAL DA ANPUH. Anais... Rio de Janeiro, 2010.

ASCHER, F. Métapolis ou l'avenir des villes. Paris: Odile Jacob, 1995.

BAKIS, H. Géopolitique de l'information. Paris: Presses Universitaires de France, 1987.

(Org.). Communications et territoires. 1. ed. Paris: La Documentation Française, 1990, v. 1.

BARBOSA, A. (Coord.). Pesquisa sobre o uso das tecnologias da informação e da comunicação no Brasil: TIC Provedores 2011. São Paulo: Comitê Gestor da Internet no Brasil, 2012.

BEAUCHAMP, K. G. History of Telegraphy: its technology and application. IET: London/UK, 2001.

BENAKOUCHE, T.; DIAS, L. C. D. Télécommunications et dynamique spatial: le cas du Brésil. In: BAKIS, H. (Org.). Communications 
et territoires. 1. ed. Paris: La Documentation Française, 1990, v. 1. p.153-163. P.177-186.

BENAKOUCHE, T. Du telephone aux nouvelles technologies: implications socials et spatiales des réseaux de telecommunication au Brésil. 1989. $254 \mathrm{f}$. Tese (Doutorado em Urbanismo) - Université Paris XII, Paris.

BERNARDES, A. H. Das perspectivas ontológicas à natureza do internauta: contribuição à epistemologia em Geografia. 264 f. 2012. Tese (Doutorado em Geografia) - Faculdade de Ciências e Tecnologia, Universidade Estadual Paulista, Presidente Prudente.

BIJKER, W. E.; LAW, J. (Eds.) J. Shaping technology/Building society: studies in sociotechnical change. Cambridge, Massachusetts: MIT, 1992.

BNDES. Privatização - Federais - Telecomunicações. Disponível em: <http://www.bndes.gov.br/SiteBNDES/bndes/bndes_pt/Institucional/BNDES_Transparente/Privatizacao/telecomunicacoes. html>. Acesso em: 28 out. 2015.

BOBBIO, N. Estado, governo e sociedade: para uma teoria geral da política. 4. ed. Tradução: Marco Aurélio Nogueira. Rio de Janeiro: Paz e Terra, 1992.

As ideologias e o poder em crise. 4. ed. Brasília: Editora Universidade de Brasília, 1995.

BOLAÑO, C. R. S. Economia politica da Internet. Aracaju: Ed. UFS, 2007.

BRANDÃO, A. C. Telecomunicações e dinâmica regional no Brasil. 1996. $244 \mathrm{f}$. Tese (Doutorado em Economia) - Universidade de Campinas, Campinas.

Território e desenvolvimento: as múltiplas escalas entre o local e o global. Capinas: Unicamp, 2007.

BRASIL. Informações sobre o PNBL. Disponível em: <http://www4. planalto.gov.br/brasilconectado/pnbl/implantacao-e-desenvolvimento>.

. Regulamentação do Serviço Especial de Televisão por Assinatura (TVA). Disponível em:<http://www.ancine.gov.br/sites/ default/files/outras-legislacoes-de-interesse/Regulamento_ Dec_95744_988_TVA.pdf>. Acesso em: 28 out. 2015.

. Lei n. 8.977, de 6 de janeiro de 1995. Disponível em: <http:// www.planalto.gov.br/ccivil_03/leis/18977.htm>. Acesso em: 28 out. 2015. 
. Decreto n. 95.744, de 23 de Fevereiro de 1988. Disponível em: <http://www2.camara.leg.br/legin/fed/decret/1988/ decreto-95744-23-fevereiro-1988-445920-publicacaooriginal-1-pe. html>. Acesso em: 28 out. 2015.

Decreto n. 7.175, de 12 de maio de 2010. Disponível em <http:// www.planalto.gov.br/ccivil_03/_Ato2007-2010/2010/Decreto/ D7175.htm>. Acesso em: 28 out. 2015.

Lei n. 4.117, de 27 de agosto de 1962. Disponível em: <http:// www.planalto.gov.br/ccivil_03/leis/14117.htm>. Aceso em: 28 out. 2015.

Lei n. 8.031, de 12 de abril de 1990. Disponível em: <http:// www.planalto.gov.br/ccivil_03/leis/L8031.htm>. Acesso em: 28 out. 2015.

Decreto n. 1.204, de 29 de julho de 1994. Disponível em: <http:// www.planalto.gov.br/ccivil_03/decreto/D1204.htm>. Acesso em: 28 out. 2015.

Pesquisa e consulta da legislação sobre o tema das telecomunicações. Disponível em: <http://www.planalto.gov.br/ccivil_03/>. Acesso em: 28 out. 2015.

BRESCIANI, A. A. "Sociedade em rede": faces virtuais da ideologia capitalista do século XXI. 2007. 171 f. Dissertação (Mestrado em Sociologia) - Universidade Estadual Paulista, Marília.

BRUNN, S. D.; CUTTER, S.L.; HARRINGTON, J.W. (Eds.). Geography and Technology. Norwell: Kluwer Academic Publishers, 2004.

CÂMARA DOS DEPUTADOS. PL 2126/2011 Disponível em: $<$ http://www.camara.gov.br/proposicoesWeb/fichadetramitacao?id Proposicao $=517255>$. Acesso em: 28 out. 2015.

CARVALHO, D. F. Padrões de concorrência e estruturas de mercado no capitalismo (uma abordagem neo-schumpeteriana). Paper do NAEA 142, 2000. p.1-14. Disponível em: www2.ufpa.br/naea/pdf. php?id=221>. Acesso em: 28 out. 2015).

CARVALHO, J. M. TV por assinatura no Brasil: um estudo do processo regulatório. 172 f. 2000. Dissertação (Mestrado em Ciência Política) - Instituto de Filosofia e Ciências Humanas, Universidade de Campinas.

CASTELLS, M. The informational city: information technology, economic restructuring, and the urban regional process. Oxford e Cambridge: Blackwell Publishers, 1992. 
A sociedade em rede. A era da informação: economia, sociedade e cultura. 4. ed. Tradução de Roneide Venâncio Majer. São Paulo: Paz e Terra, 1999. v. 1.

A galáxia da internet: reflexões sobre a internet, os negócios e a sociedade. Tradução de Maria Luiza X. de A. Borges. Rio de Janeiro: Jorge Zahar, 2003.

CASTILLO ARGAÑARÁS, L. F. Comercio, Espacio y Telecomunicaciones Satelitales. Buenos Aires: Editorial Dunken, 2008

CASTILLO, R. Sistemas orbitais e uso do território. Integração eletrônica e conhecimento digital do território brasileiro. 1999. 307 f. Tese (Doutorado em Geografia) - Faculdade de Filosofia, Letras e Ciências Humanas - Universidade de São Paulo, São Paulo.

- Tecnologias da informação e organização do território brasileiro: monitoramento e fluidez. In: SOUZA, M. A. A. (Org.). Território brasileiro: usos e abusos. Campinas: Edições Territorial, 2003. p.41-53.

CASTRO, I. E. O problema da escala. In: CASTRO, I. E.; GOMES, P. C. C.; CORREAA, R. L. (Orgs.). Geografia: conceitos e temas. 7. ed. Rio de Janeiro: Bertrand Brasil, 2005. p.117-140.

CATAIA, M. Território nacional e fronteiras internas: a fragmentação do território brasileiro. 2001. 255 f. Tese (Doutorado em Geografia) Faculdade de Filosofia, Letras e Ciências Humanas, Universidade de São Paulo, São Paulo.

CAVALCANTE, A. B. O processo de privatização do setor de telecomunicações brasileiro: novas linhas de atuação. In: ENCONTRO ANUAL DA ASSOCIAÇÃO NACIONAL DOS PROGRAMAS DE PÓS-GRADUAÇÃO EM ADMINISTRAÇÃO, 23., 1999, Salvador. Anais... Foz do Iguaçu: Enanpad, 1999.

CAVALCANTE, S. As telecomunicações após uma década da privatização: a face oculta do "sucesso". Eptic Online - Revista Eletrônica Internacional de Economia Política da Informação, da Comunicação e da Cultura, v. 13, n.1, Não paginado. Disponível em: <http://www.seer. ufs.br/index.php/eptic/article/view/44>. Acesso em: 28 out. 2015.

CETIC. Dados relacionados à tecnologia da informação. Disponível em: $<$ http://www.cetic.br>. Acesso em: 28 out. 2015.

CHESNAIS, M. Information et prise de decision dan l'enterprise, transformation des rapports àl espace. In: BAKIS, H. (Org.). Communications et territoires. 1 ed. Paris: La Documentation Française, 1990, v. 1. p.153-163. 
CLARO. Conheça a Claro. Disponível em: <http://www.claro.com. $\mathrm{br} /$ institucional/conheca-claro/regiao/ddd18/SP-OUT/tv-2/>. Acesso em: 28 out. 2015.

CONTEL, F. B. A internalização da categoria "informação". In: VIDEIRA S. L.; COSTA P.A.; FAJARDO, S. (Orgs.). Geografia econômica: (re)leituras contemporâneas. Rio de Janeiro: Letra Capital, 2011.

CONVERGÊNCIA DIGITAL. TICs são destaque na receita de Serviços no Brasil. Disponível em: < http://convergenciadigital.uol. com.br/cgi/cgilua.exe/sys/start.htm?infoid=34693\&sid=5\#.Uuk_ fhBdVu4>. Acesso em: 28 out. 2015).

CORREAA, R. L. Interações espaciais. In: CASTRO, I. E.; GOMES, P. C. C.; CORREAA, R. L. (Org.) Explorações geográficas: percursos no fim do século. Rio de Janeiro: Bertrand Brasil, 1997. p.279-318.

COSTA, W. M. O Estado e as políticas territoriais no Brasil. São Paulo: Contexto, 1988.

COSTA, M. C. Mudanças institucionais e privatização na década de 90: uma comparação entre Europa e América Latina no setor de telecomunicações. Disponível em: <http://www.ige.unicamp.br/site/publicacoes/dpct/Texto-17.doc > . Acesso em: 28 out. 2015.

COUTINHO, L.; CASSIOLATO, J. L., SILVA, A. L. G. Introdução: telecomunicações, globalização e competitividade. In:

(Coords.). Telecomunicações, globalização e competitividade. Campinas: Papirus, 1995. p.13-38.

COUTO, G. H. R. Celulares: A tecnologia do telefone móvel mediando uma nova linguagem. In : XII Congresso Brasileiro de Ciências da Comunicação da Região Sudeste. Anais... Juiz de Fora, 2007.

CHRISTALLER, W. Central places in Southern Germany. 1. ed. Englewood Cliffs: Prentice-Hall Inc., 1966.

CURIEN, N. ; GENSOLLEN, M. Réseaux de télécommunications et aménagement de l'espace. Révue Géographique de l'Est, v. 1, p.47-56, 1985.

DALMAZO, R. A. As mediações cruciais das mudanças políticos-institucionais do Brasil. Porto Alegre: FEE, 2000.

DANTAS, M. A lógica do capital-informação. A fragmentação dos monopólios e a monopolização dos fragmentos num mundo de comunicações globais. Rio de Janeiro: Contraponto, 2002.

DARDEL, E. O homem e a terra: natureza da realidade geográfica. São Paulo: Perspectiva, 2011. 
DEMATTEIS, G. Le metafore della terra. La geografia umana tra mito e scienza. 2. ed. Milão: Feltrinelli, 1986.

Introduction. Cities as nodes of urban network. In: BONAVERO, P.; DEMATTEIS, G.; SFORZI, F. (Org.). The Italian urban system: towards European integration. Aldershot e Vermont: AshgatePublising LTD, 1999.

DERTOUZOS, M. O que será: como o novo mundo da informação transformará nossas vidas? São Paulo: Cia das Letras, 1997.

DIAS, L. C. D. Le Reseaux de telecommunication et l'organization territoriale et urbaine au Bresil. 1991. 304 f. Tese (Doutorado em Geografia) - L’Université Paris IV, Paris.

Réseaux d'information et réseau urbain au Brésil. Paris: L'Harmattan, 1995.

Redes eletrônicas e novas dinâmicas do território brasileiro. In: CASTRO, I. E. et al. (Orgs.). Brasil: questões atuais da reorganização do território. Rio de Janeiro: Bertrand Brasil, 1996. p.115-144.

Os sentidos da rede: notas para discussão. In: Dias, L. C. D.; SILVEIRA, R. L. L. (Orgs.). Redes, Sociedades e Territórios. Santa Cruz do Sul: EDUNISC, 2005. p.11-28.

DIAS, L. R.; CORNILS, P.(Coord.). Telecomunicações no desenvolvimento do Brasil. São Paulo: Momento Editorial, 2008.

DICKEN, P. Global shift: transforming the world economy. 3. ed. New York: The Guilford Press, 1998.

DICKEN, P.; Malmberg, A. Firms in territories: a relational perspective. Economic Geography, v. 77, n. 4, p.345 - 363, out. 2001. Disponível em: <http://www.jstor.org/stable/3594105?origin=crossref $>$ Acesso em: 28 out. 2015.

DONOS DA MÍDIA. Dados relacionados às empresas de comunicação no Brasil. Disponível em: < http://www.donosdamidia.com.br/>. Acesso em: 28 out. 2015.

Rede. Disponível em: <http://donosdamidia.com.br/ rede/4023>. Acesso em: 28 out. 2015.

ELETRONET. Fibras ópticas de propriedade da Eletronet S.A, 2012. Disponível em: <http://www.eletronet.com/rede.htm>. Acesso em: 28 out. 2015.

EMBRATEL PARTICIPAÇÕES S. A. Relatório da Administração Embratel Participações S.A. Disponível em: <http://www.embratel. 
com.br/Embratel02/files/dc/08/07/DF\%20EBPAR\%202012\%20 -\%2020-03-2013.pdf>. Acesso em: 28 out. 2015.

. Embratel avança na sua estratégia para oferecer serviços locais através da aquisição da Vésper. Disponível em: <http://www.embratel. com.br/Embratel02/files/dc/01/02/Vesper\%20Concl\%20PRPor. PDF>. Acesso em: 28 out. 2015.

EMPLASA. PAM formula visão do futuro desejado para 2040. Disponível em: <http://www.emplasa.sp.gov.br/newsletter/maio/interno/ caracteristicas_objetivos.asp>. Acesso em: 28 out. 2015.

ESTADÃO. UOL recompra ações para fechar o capital. Disponível em: $<$ http://www.estadao.com.br/noticias/impresso, uol-recompra-acoes--para-fechar-o-capital-,816722,0.htm>. Acesso em: 28 out. 2015.

Terra paga US\$ 1,9 mi pelos clientes da AOL Brasil. Disponível em: <http://www.estadao.com.br/arquivo/tecnologia/2006/ not20060103p71047.htm>. Acesso em: 28 out. 2015.

TIM fecha acordo para compra da Intelig. 17 de abril de 2009. Disponível em: <http://www.estadao.com.br/noticias/impresso,tim-fecha-acordo-para-compra-da-intelig, 356127,0.htm>. Acesso em: 28 out. 2015.

TIM compra AES Atimus por R\$ 1,6 bilhão. 8 de julho de 2011. Disponível em: <http://economia.estadao.com.br/noticias/negocios-servicos, tim-compra-aes-atimus-por-r-16-bilhao-, 75119,0. htm>. Acesso em: 28 out. 2015.

América Móvil recebe aval da Anatel para controlar a NET. Disponível em: <http://www.estadao.com.br/noticias/geral,america-movil-recebe-aval-da-anatel-para-controlar-a-net,828367,0.htm>. Acesso em: 28 out. 2015.

EXAME. Governo zera alíquota de PIS/COFINS para smartphone. Disponível em: <http://exame.abril.com.br/tecnologia/noticias/ governo-zera-aliquota-de-pis-cofins-para-smartphone $>$. Acesso em: 28 out. 2015.

. IG e Ongoing traçam plano de transição de 60 dias. Disponível em: $<$ http://exame.abril.com.br/negocios/aquisicoes-fusoes/noticias/ ig-e-ongoing-tracam-plano-de-transicao-de-60-dias/>. Acesso em: 28 out. 2015.

Antes de ser vendido, iG caiu no ranking dos portais da web. Disponível em: <http://exame.abril.com.br/tecnologia/noticias/antes-de- 
-ser-vendido-ig-caiu-no-ranking-dos-portais-da-web>. Acesso em: 28 out. 2015.

Claro S.A. teve prejuízo líquido de $R \$ 880$ milhões em 2012. 1 de abril de 2013. Disponível em: <http://exame.abril.com.br/negocios/ noticias/claro-s-a-registrou-prejuizo-liquido-de-r-880-milhoes-em-2>. Acesso em: 28 out. 2015.

. Decisão favorável da CVM eleva lucro da Oi em 2012. 26 de abril de 2013. Disponível em: <http://exame.abril.com.br/negocios/noticias/decisao-favoravel-da-cvm-eleva-lucro-da-oi-em-2012>. Acesso em: 28 out. 2015.

Decisão favorável da CVM eleva lucro da Oi em 2012. Disponível em: <http://exame.abril.com.br/negocios/noticias/decisao-favoravel-da-cvm-eleva-lucro-da-oi-em-2012>. Acesso em: 28 out. 2015.

Revista lista os mais influentes da Era da Informação. Disponível em: <http://exame.abril.com.br/tecnologia/noticias/revista-lista-os-mais-influentes-da-era-da-informacao?p=10>. Acesso em: 28 out. 2015.

Net Serviços fatura R \$ 7,94 bilhões em 2012, alta de 18,6\%. Disponível em: <http://exame.abril.com.br/negocios/noticias/net-servicos-fatura-r-7-94-bilhoes-em-2012-alta-de-18-6>. Acesso em: 28 out. 2015.

Tele Norte Leste Participações aprova incorporação pela futura $\mathrm{Oi}$

S.A. Disponível em: <http://www.valor.com.br/empresas/2544496/ tele-norte-leste-participacoes-aprova-incorporacao-pela-futura-oi-sa>. Acesso em: 28 out. 2015.

FERRARI, A. M. Telecomunicações: evolução \& revolução. São Paulo: Érica, 1991.

FERREIRA, A. H. Caracterização e dinâmica da inovação dos serviços produtivos intensivos em conhecimento no setor de telecomunicações. 2007. 216 f. Tese (Doutorado em Política Científica e Tecnológica) Universidade Estadual de Campinas, Instituto de Geociências, Campinas.

FISCHER, A. Indústria, ordenamento e território: a contribuição de André Fischer. Tradução e organização: Olga Lúcia Castreghini de Freitas Firkowski e Eliseu Savério Sposito. São Paulo: Expressão Popular, 2008.

FOLHA DE S.PAULO. Fusão entre Telefônica e Vivo será decidida hoje. Disponível em: <http://www1.folha.uol.com.br/colunas/ 
mercadoaberto/2013/05/1283313-fusao-entre-telefonica-e-vivo-sera-decidida-hoje.shtml>. Acesso em: 28 out. 2015.

Acordo entre Oi e Portugal Telecom foi alívio para o governo. Disponível em: <http://www1.folha.uol.com.br/ mercado/2013/10/1351048-acordo-entre-oi-e-portugal-telecom-foi-alivio-para-o-governo.shtml>. Acesso em: 28 out. 2015.

. CPI fracassa na identificação dos responsáveis pela espionagem dos EUA a brasileiros. Disponível em: <http://www1.folha.uol. com.br/mundo/2014/04/1437177-cpi-fracassa-na-identificacao-dos-responsaveis-pela-espionagem-dos-eua-a-brasileiros.shtml>. Acesso em: 28 out. 2015.

Telefónica fecha acordo de $€ 7$ bi para comprar GVT. Disponível em: <http://www1.folha.uol.com.br/mercado/2014/09/1518379telefonica-fecha-acordo-de-7-bi-de-euros-para-comprar-gvt.shtml>. Acesso em: 28 out. 2015.

FOUCAULT, M. Microfísica do poder. Organização e tradução: Roberto Machado. Rio de Janeiro: Edições Graal, [1979] 2001.

Ditos e escritos, Volume IV: estratégia, poder-saber. 3. ed. Organização Manoel Barros da Mota e Tradução: Vera Lucia Avellar Ribeiro. Rio de Janeiro: Forense Universitária, 2012.

FRANSMAN, M. Analysing the evolution of industry: the relevance of the telecommunications industry. Economics of Innovation $\mathcal{E}$ New Technology, v. 10, n. 2/3, p.109-140, Abr. 2001.

G1. Telefônica/Vivo tem lucro de R\$4,45 bilhões em 2012. Disponível em: <http://g1.globo.com/economia/negocios/noticia/2013/02/ telefonicavivo-tem-lucro-de-r-445-bilhoes-em-2012.html>. Acesso em: 28 out. 2015.

TIM registra lucro de $R \$ 1,449$ bilhão em 2012, alta de 13,4\%. 5 de fevereiro de 2013. Disponível em: <http://g1.globo.com/economia/ negocios/noticia/2013/02/tim-registra-lucro-de-r-1449-bilhao-em-2012-alta-de-134.html>. Acesso em: 28 out. 2015.

Net, Claro e Embratel se unem para lançar serviço de telecomunicações. 5 de outubro de 2011. Disponível em: <http://g1.globo.com/ tecnologia/noticia/2011/10/net-claro-e-embratel-se-unem-para-lancar-servico-de-telecomunicacoes.html>. Acesso em: 28 out. 2015.

Venda de chips de TIM, Oi e Claro está liberada a partir desta sexta. Disponível em: <http://g1.globo.com/jornal-hoje/noticia/2012/08/operadoras-punidas-pela-anatel-voltam-vender-linhas-de-celular.html>. Acesso em: 28 out. 2015. 
GAFFARD, J.; KRAFFT, J. Telecommunications: understanding the dynamics of the organization of the industry. 2001. Disponível em: <http:// halshs.archives-ouvertes.fr/docs/00/20/36/55/PDF/Telecomvisions-2001.pdf>. Acesso em: 28 out. 2015.

GATES, B. A estrada do futuro. São Paulo: Cia da Letras, 1995.

GIBSON, W. Neuromancer. 1 ed. New York: Ace Books, 1984

GEIGER, P.P. Regionalização. Revista Brasileira de Geografia, Rio de Janeiro, v. 31, n.1, p.111-118, 1969.

GERTEL, S. Reconhecendo o território: a informação e o espaço geográfico. In: SOUZA, M. A. A. (Org.). Território brasileiro: usos e abusos. Campinas: Edições Territorial, 2003. p.108-116.

GILLESPIE, A. E. The Geography of telecommunications. In: BAKIS, H. et al. Information et organization spatiale. Caen: Paradigme, 1988. p.61-78

GLOBO.COM. Anuncie aqui. Disponível em: <http://anuncie.globo. $\mathrm{com} /$ mediakit/globocom/home-globocom.html>. Acesso em 28 out. 2015.

GLOBOSAT. Canais Globosat. Disponível em: < http://canaisglobosat. globo.com/index.php/canais>. Acesso em: 28 out. 2015.

GOEMANN, R. G. A abordagem sistêmica como alternativa estratégica para provedores locais de acesso à internet. 2005. $138 \mathrm{f}$. Dissertação (Mestrado em Administração) - Centro de Ciências Sociais Aplicadas, Universidade Regional de Blumenau, Blumenau.

GOMES, C. Informação, comunicação e o conhecimento do território: dinâmicas socioespaciais e a questão do lugar no Brasil. In: SOUZA, M. A. A. (Org.). Território brasileiro: usos e abusos. Campinas: Edições Territorial, 2003. p. 54-76.

GRAHAM, S.; MARVIN, S. Telecommunications and the city: electronic spaces, urban places, Londres: Routledge, 1996.

GRAMSCI, A. Maquiavel, a política e o Estado moderno. 2. ed. Tradução: Mario Gazzaneo. Rio de Janeiro: Civilização brasileira, 1976.

GRAS, A. Les réseaux, les machines et la mégamachine: sur l'origine des systèmes techniques contemporains. In: MUSSO, P.(Dir.) Réseaux et société. Paris: PUF, 2003. p.141-152.

GUILHOTO, L. F. M.; RUBAL, J. M. Estratégia de lançamento de novos produtos e de serviços inovadores em operadoras do sistema de telefonia fixo comutado (STFC). In: SBRAGIA, Roberto; GALINA, Simone V. R. (Eds.). Gestão da inovação no setor de telecomunicações. São Paulo: PGT/USP, 2004. p.193-230. 
GVT. Sobre a GVT. Disponível em: <http://www.gvt.com.br/PortalGVT/Institucional>. Acesso em: 28 out. 2015.

HARVEY, D. The limits to capital. Oxford: Basil Blackwell, 1982.

Condição pós-moderna. 19 ed. Tradução de Adail Ubirajara Sobral e Maria Stela Gonçalves. São Paulo: Loyola, 2010.

HEPWORTH, M. E. Geography of the information economy. Londres e Nova York: The Gilford Press, 1990.

HOUAISS, A.; VILLAR, M. S.; FRANCO, F. M. M. Dicionário Houaiss da Língua Portuguesa. São Paulo: Objetiva, 2009. Disponível em: $<$ http://www.uol.com.br/dicionario > . Acesso em: 28 out. 2015.

. Norma. Disponível em: <http://houaiss.uol.com.br/ busca?palavra=norma $>$. Acesso em: 28 out. 2015.

IBGE. Informações sobre estimativas populacionais no Brasil para o ano de 2009. Disponível em: <ftp://ftp.ibge.gov.br/Estimativas_Projecoes_ Populacao/Estimativas_2009>. Acesso em: 4 jul. 2010.

. IDS 2010: país evolui em indicadores de sustentabilidade, mas ainda há desigualdades socioeconômicas e impactos ao meio ambiente. Disponível em: <http://www.inesc.org.br/noticias/noticias-gerais/2010/setembro/ids-2010-pais-evolui-em-indicadores-de-sustentabilidade-mas-ainda-ha-desigualdades-socioeconomicas-e-impactos-ao-meio-ambiente>. Acesso em: 28 out. 2015.

Acesso à Internet e posse de telefone móvel celular para uso pessoal 2011. Disponível em: <http://www.ibge.gov.br/home/estatistica/ populacao/acessoainternet2011/default.shtm>. Acesso em: 28 out. 2015.

Regiões de Influência das Cidades. Rio de Janeiro, 2008. Disponível em: <http://www.ibge.gov.br/home/geociencias/geografia/ regic.shtm>. Acesso em: 28 out. 2015.

. Sinopse do Censo Demográfico (2010). Rio de Janeiro, 2011. Disponível em: <http://www.ibge.gov.br/home/estatistica/populacao/ censo2010/sinopse/default_sinopse.shtm>. Acesso em: 28 out. 2015. Pesquisa Nacional por Amostra de Domicílios (PNAD). Rio de Janeiro: 2007. Disponível em: <http://www.ibge.gov.br/home/ estatistica/pesquisas/pesquisa_resultados.php?id_pesquisa $=40>$. Acesso em: 28 out. 2015.

Pesquisa Nacional por Amostra de Domicílios (PNAD). Rio de Janeiro, 2011. Disponível em: < http://www.ibge.gov.br/home/ estatistica/populacao/trabalhoerendimento/pnad2005/> . Acesso em: 28 out. 2015. 
IG. A história do portal. Disponível em: <http://aniversario10anos. ig.com.br/10+anos+ig.html>. Acesso em: 13 mar. 2013.

Central do anunciante. Disponível em: <http://centraldoanunciante.ig.com.br/audiencia/ig/5072fa1e335da41e52000

389.html>. Acesso em: 28 out. 2015.

INFO ONLINE. AOL Brasil fecha as portas no dia 17 de março. Disponível em: <http://info.abril.com.br/aberto/infonews/022006/01022006-9.shl>. Acesso em: 28 out. 2015.

INFOMONEY. DirecTV revisa para baixo base de clientes da Sky Brasil.

Disponível em: <http://www.infomoney.com.br/negocios/grandes-empresas/noticia/2840605/directv-revisa-para-baixo-base-clientes-sky-brasil>. Acesso em: 28 out. 2015.

INTERNET WORLD STATS. Informações sobre o uso da internet no mundo. Disponível em: <http://www.internetworldstats.com>. Acesso em: 28 out. 2015.

IOZZI, F. L. Políticas territoriais das empresas de telecomunicações no Brasil: universalização do serviço de telefonia fixa. 2006. 235 f. Dissertação (Mestrado em Geografia) - Instituto de Geociências, Universidade Estadual de Campinas, Campinas.

JAROSLAV, S. Ondas e antenas. São Paulo: Érica, 1987.

JURADO DA SILVA, P.F. Cidades pequenas e indústria: contribuição para a análise da dinâmica econômica da região de Presidente Prudente-SP.2011. 282 f. Dissertação (Mestrado em Geografia) - Faculdade de Ciências e Tecnologia, Universidade Estadual Paulista, Presidente Prudente.

KAHIL, S. P. Psicoesfera: uso corporativo da esfera técnica do território e o novo espírito do capitalismo. Sociedade e Natureza, Uberlândia, v. 22, n. 3, p.475-485, 2010. Disponível em: <http://www. seer.ufu.br/index.php/sociedadenatureza/article/viewFile/11332/ pdf_12Uberlândia >. Acesso em: 7 nov. 2013.

KELLERMANN, A. Telecommunications and Geography. Londres: Belhaven, 1993.

LACOSTE, Y. La Géographie, Ca sert d' abord, pour faire la guerre. 3. ed. Paris: La Découverte, [1976] 1985.

LAKATOS, E. M.; MARCONI, M. A. Fundamentos de metodologia científica. 3. ed. São Paulo: Atlas, 2005.

LÉVY, P. Cibercultura. Tradução de Carlos Irineu da Costa. São Paulo: Editora 34, 1999. 
LIMA, V. A. Globalização e políticas públicas no Brasil: a privatização das comunicações entre 1995 e 1998. Revista Brasileira de Política Internacional, Brasília, v. 41, n. 2, p.118-138.

LOJKINE, J. A revolução informacional. Tradução de José Paulo Netto. São Paulo: Cortez, 1995.

LOPES, H. M. Agricultura, modernização e uso corporativo do território. 2006. 78 f. Dissertação (Mestrado em Geografia Humana) - Faculdade de Filosofia, Letras e Ciências Humanas, Universidade de São Paulo, São Paulo.

LOURAL, C. A.; LEAL, R. L. V. Desafios e oportunidades do setor de telecomunicações no Brasil. Textos para discussão. Brasília: CEPAL/ IPEA, 2010. Disponível em: <http://www.ipea.gov.br/portal/images/stories/PDFs/TDs/td_1545.pdf>. Acesso em: 13 dez. 2013.

MALUF, S. Teoria geral do Estado. 14. ed. São Paulo: sugestões literárias, 1982.

MAMIGONIAN, A. Kondratieff, ciclos médios e organização do espaço. Geosul, Florianópolis, v. 14, n. 28, p.152-157, 1999.

MANTOVANI, C. M. C. A. Info-entretenimento na telefonia celular: informação, mobilidade e interação social em um novo espaço de fluxos. 2006. 152 f. Dissertação (Mestrado em Ciência da Informação) - Escola de Ciência da Informação da Universidade Federal de Minas Gerais, Belo Horizonte.

MARX, K. O Capital: crítica da economia política. Tradução: Regis Barbosa e Flávio R. Kothe. 2. ed. São Paulo: Nova Cultural, 1985a. (Tomo 1).

. O Capital: crítica da economia política. Tradução: Regis Barbosa e Flávio R. Kothe. 2. ed. São Paulo: Nova Cultural, 1985b. (Tomo 2). O Capital: crítica da economia política. Tradução: Regis Barbosa e Flávio R. Kothe. 2. ed. São Paulo: Nova Cultural, 1985c. (Tomo 3). . Grundrisse: Foundations of the critique of political economy (Rough Draft). Tradução: Martin Nicolaus. Londres: Penguin Books, 1993.

MATTOS, C. A. Nuevas estrategias empresariales y mutaciones territoriales en los procesos de reestructuración en América Latina. Revista Paraguaya de Sociología, Ano 29, n. 84, p.145-170, 1992.

McLUHAN, M. La Aldea Global. Barcelona: Gedisa S/A, 1989.

MELO, P.L. R.; MUSSENGUE, M. M. A. As atuações mexicana e espanhola no segmento de telecomunicações na América Latina. Internext - Revista Eletrônica de Negócios Internacionais da ESPM, São Paulo, v. 6, n. 2, p.66-89, jul./dez. 2011. Disponível em: < http://internext. 
espm.br/index.php/internext/article/view/124> Acesso em: 28 out. 2015.

MINISTÉRIO DAS COMUNICAÇÕES. Disponível em: < http:// www.mc.gov.br/publicacoes/doc_download/1518-apresentacao-do-ministro-das-comunicacoes-paulo-bernardo-em-audiencia-publica-na-comissao-de-servicos-e-infraestrutura-do-senado-brasilia-df-02-10-13>. Acesso em: 28 out. 2015.

MIRANDA, P.; KUME, H.; PIANI, G. Liberalização do comércio de serviços: o caso do setor de telecomunicações no Brasil (texto para discussão 1599). Rio de Janeiro: IPEA, 2011. Disponível em: <http://www.ipea.gov.br/portal/index.php?option=com content\&view $=$ article\&id $=9771>$. Acesso em: 28 out. 2015.

MOGUILLANSKY, G. Las reformas del sector de telecomunicaciones en Chile y el comportamiento de la inversión. Santiago: Cepal/ONU, 1998.

MONTEIRO, A. Q. Trabalho, ciberespaço e acumulação de capital : estudo sobre produção e consumo na interatividade da internet comercial. 2008. 166 f. Dissertação (Mestrado em Ciências Sociais) - Faculdade de Filosofia e Ciências, Universidade Estadual Paulista.

MORE, J. D. et al. Avaliação da eficiência do portal Globo.com: um estudo de caso à luz da teoria dos conjuntos Fuzzy. Revista de Gestão da Tecnologia e Sistemas de Informação, São Paulo, v. 7 n. 16, p.353-372. 2010. Disponível em: <http://www.scielo.br/scielo.php?pid=S1807$-17752010000200006 \&$ script=sci_arttext $>$. Acesso em: 28 out. 2015.

MOREIRA, R. Os períodos técnicos e o paradigma do espaço do trabalho. Ciência geográfica, Bauru: AGB, ano VI, v. 2, n. 16, p.4-8, 2000.

Da região à rede e ao lugar: a nova realidade e o novo olhar geográfico sobre o mundo. Etc.. Rio de Janeiro, v. 1, n. 1 (3), p.55-70, 2007. Disponível em: <http://www.uff.br/etc/UPLOADs/etc\%20 2007_1_3.pdf>. Acesso em: 28 out. 2015.

MORGAN, K. Digital Highways: the new telecommunications era. Geoforum, n. 3 v. 23, p.317-332, 1992.

MOTTA, M. P. Topologia dos backbones de internet no Brasil. Sociedade E N Natureza, Uberlândia, ano 24, n. 1, p.21-36, 2012. Disponível em : < http://www.scielo.br/pdf/sn/v24n1/v24n1a03.pdf>. Acesso em: 28 out. 2015.

MUNHOZ, E. R. A Rede Globo de Televisão no território brasileiro através do sistema de emissoras afiliadas. 156 f. 2008. Dissertação (Mestrado em Geografia) - Faculdade de Filosofia, Letras e Ciências Humanas, Universidade de São Paulo, São Paulo. 
MURILLO, M. V. Political competition, partisanship and policy making in Latin American public utilities. Nova York : Cambridge University Press, 2009.

MUSSO, P.(Dir.) Réseaux et société. Paris: PUF, 2003.

MYRDAL, G. Teoria econômica e regiões subdesenvolvidas. Editora: Saga: Rio de Janeiro, 1965.

NALLAR, D. M. El estado regulador y el nuevo mercado del servicio público. Análisis jurídico sobre la privatización, la regulación y los entes regulatorios. Buenos Aires: Depalma, 1999.

NEGRI, B. Concentração e desconcentração industrial em São Paulo (18801990). Campinas: Editora da UNICAMP, 1996.

NET. História. Disponível em: <http://www.netcombo.com.br/ netPortalWEB/appmanager/portal/desktop?_nfpb=true\&_ pageLabel=institucional_sobre_net_historia_paginacao_book_2 page>. Acesso em: 9 jul. 2013.

. Relações com investidores. Disponível em: <http://www. netcombo.com.br/static/ri/>. Acesso em: 28 out. 2015.

NIC.BR. Brasil tem 1.934 provedores de internet, mas somente seis deles concentram 80\% do mercado. Disponível em: <http://www.nic.br/ imprensa/clipping/2011/midia1221.htm>. Acesso em: 6 fev. 2013.

NOVAES, A. Privatização do setor de telecomunicações no Brasil. BNDES, 2000. Disponível em: <http://www.bndes.gov.br/SiteBNDES/ bndes/bndes_pt/Institucional/Publicacoes/Consulta_Expressa/ Setor/Telecomunicacoes/200002_5.html>. Acesso em: 28 out. 2015.

OFFNER, J. M. 'Territorial desregulation': local autorities at risk from tecnical networks. International Journal of Urban and Regional Research, v. 24.1, p.165-181, 2000.

OI. Informações para investidores. Disponível em: <http://ri.oi.com.br/ oi2012 $/$ web $/$ conteudo_pt.asp? idioma $=0 \&$ tipo $=43845 \&$ conta $=28>$. Acesso em: 28 out. 2015.

. Perfil corporativo. Disponível em: <http://ri.oi.com.br/oi2012/ web $/$ conteudo_pt.asp? idioma $=0 \&$ conta $=28 \&$ tipo $=43302>$. Acesso em: 28 out. 2015.

Relação com colaboradores. Disponível em: < http://relatorioanual2011.oi.com.br/desempenho-socioambiental/relacao-com-colaboradores >. Acesso em: 28 out. 2015.

Oi S.A. registra lucro consolidado de $R \$ 346$ milhões. Disponível em: <http://www.oi.com.br/oi/sobre-a-oi/sala-de-imprensa/ 
opcoes $/$ press-releases $/$ detalhe? imprensa $=\mathrm{c} 5 \mathrm{f} 8 \mathrm{~b} 2 \mathrm{c} 55 \mathrm{f} 657310 \mathrm{VgnVC}$ M10000031d0200a >. Acesso em: 28 out. 2015.

OHMAE, K. Triad power: the coming shape of global competition. Nova York: Free press, 1985

ONEI. Oficina Nacional de Estadísticas e Información. Disponível em: $<$ http://www.one.cu/>. Acesso em: 28 out. 2015.

ONGOING. História. Disponível em: <http://www.ongoing.com/quemsomos.html>. Acesso em: 28 out. 2015.

ONU. Minuto da telefonia móvel no Brasil é um dos mais caros entre países em desenvolvimento, revela ONU. Disponível em: <http://www.onu. org.br/minuto-da-telefonia-movel-no-brasil-e-um-dos-mais-caros-entre-paises-em-desenvolvimento-revela-onu/>. Acesso em: 28 out. 2015.

PDT. Governador Leonel Brizola e a Companhia Riograndense de Telecomunicações - CRT. Disponível em: <http://www.pdtrs.org.br/todos-os-artigos/252-brizola-e-a-crt>. Acesso em: 28 out. 2015.

PENNA, N. A. A questão urbana ambiental: política urbana e gestão da cidade. In: X Encontro Nacional da Anpur, 2003, Belo Horizonte. Anais... Belo Horizonte, 2003.

PENNA FILHO, P.B. A. Telecomunicações: o desafio da integração nacional. Embratel 1967-2004. Rio de Janeiro: Editora Ciência Moderna Ltda., 2009.

PINTO, A. V. O conceito de tecnologia. Rio de Janeiro: Contraponto, 2005. v. 1.

. O conceito de tecnologia. Rio de Janeiro: Contraponto, 2005. v. 2.

PIRES, H. F. Gestão Urbana e Tecnologia de Informação: a contribuição da tecnologia de informática - Recife (1979/87). 1988. Dissertação. (Mestrado em Desenvolvimento Urbano) - Universidade Federal de Pernambuco, Recife.

Reestruturação industrial e alta-tecnologia no Brasil: as indústrias de informática de São Paulo. 1995. 256 f. Tese (Doutorado em Geografia) - Faculdade de Filosofia, Letras e Ciências Humanas, Universidade de São Paulo, São Paulo.

A produção morfológica do ciberespaço e a apropriação dos fluxos informacionais no Brasil. Scripta Nova. Revista electrónica de geografía y ciencias sociales. Barcelona: Universidad de Barcelona, 1 de agosto de 2005, v. IX, n. 194 (19). Disponível em: <http://www.ub.es/geocrit/ sn/sn-194-19.htm>. Acesso em: 28 out. 2015. 
POCHMANN, M.; PORTO, J. R. D. A informática e as telecomunicações no Brasil. Campinas: Organização Internacional do Trabalho, 2000.

POSSEBON, S. Globo e Abril diante de um novo paradigma comunicacional: a internet. Brasília: UnB, 2002.

Tv por assinatura: 20 anos de evolução. São Paulo: Save Produção, 2009.

PROCON SÃO PAULO. Ranking de atendimentos. Disponível em: $<$ http://www.procon.sp.gov.br/pdf/ranking_atendimentos_2013_ procon_sp.pdf $>$. Acesso em: 28 out. 2015.

QUINTELLA, R. H.; COSTA, M. A. O setor de telefonia móvel do Brasil após o SMP: as estratégias das operadoras e a convergência fixa-móvel. Revista de Administração Pública (Online), Rio de Janeiro, v. 43, n.1, p.123-150, 2009. Disponível em: R7. Entenda a proibição da venda de novas linhas de celular pela Anatel. Disponível em: <http://noticias.r7.com/economia/noticias/entenda-a-proibicao-da-venda-de-novas-linhas-de-celular-pela-anatel-20120728.html?question $=0>$. Acesso em: 28 out. 2015.

RAFFESTIN, C. Por uma geografia do poder. Tradução de Marília Cecília França. São Paulo: Ática, 1993 [1980].

RAMOS, M. C.; MARTINS, M. A. TV por Assinatura no Brasil: conceito, origens, análise e perspectivas. In: Encontro anual da Sociedade Brasileira de Estudos Interdisciplinares da Comunicação (Intercom), Anais... Universidade Federal de Sergipe, 1995.

TV por Assinatura no Brasil: conceito, origens, análise e perspectivas. Tendências XXI, Lisboa, Ano I, n. 1, p.105-123, 1996.

RANGEL, I. Recursos ociosos e política econômica. São Paulo: Hucitec, 1980.

500 anos de desenvolvimento da América e do Brasil. Revista Geosul, Florianópolis, n. 15, p.7-12, 1983.

Economia: milagre e anti-milagre. Rio de Janeiro: Jorge Zahar Editor, 1986.

REDCLARA. Disponível em: < http://www.redclara.net/index. php?option $=$ com_content $\&$ task $=$ view $\&$ id $=51 \&$ Itemid $=77]>$. Acesso em: 18 fev. 2013.

RICHARDSON, R. J. et al. Pesquisa social: métodos e técnicas. 3. ed. São Paulo: Atlas, 2011.

RNP. Rede Nacional de Pesquisa. Disponível em: < http://www.rnp.br/ backbone/index.php>. Acesso em: 28 out. 2015. 
Mapa dos backbones. Disponível em: <http://www.rnp.br/backbone/index.php>. Acesso em: 28 out. 2015.

ROZAS BALBONTÍN, P. Privatización, reestructuración industrial y prácticas regulatorias en el sector telecomunicaciones. Santiago: Cepal/ Naciones Unidas, 2005. Disponível em: <www.cepal.org/publicaciones $/ x m l / 8 / . . . / l c l 2331$ e.pdf $>$. Acesso em: 28 out. 2015.

SALGADO, L. H.; MOTA, R. S. (Eds.). Marcos regulatórios no Brasil: o que foi feito

e o que falta fazer. Rio de Janeiro: Ipea, 2005.

SANTOS, M. Por uma Geografia Nova. São Paulo, Hucitec, 1978. . Espaço e sociedade: ensaios. 2. ed. Petrópolis: Vozes, 1979. Metamorfoses do espaço habitado. São Paulo: Hucitec, 1988. A urbanização brasileira. São Paulo: Hucitec, 1993. . A natureza do espaço: técnica e tempo, razão e emoção. São Paulo: Hucitec, 1996a.

Metamorfoses do espaço habitado: fundamentos teóricos e metodológicos da Geografia. 4. ed. Hucitec: São Paulo, 1996b.

Técnica, espaço, tempo: globalização e meio técnico-científico-informacional. 4. ed. São Paulo: Hucitec, 1998.

Por uma outra globalização: do pensamento único à consciência universal. 6. ed. Rio de Janeiro: Record, 2001.

. Da totalidade ao lugar. São Paulo: Editora da Universidade de São Paulo, 2005.

A natureza do espaço: técnica e tempo, razão e emoção. 4. ed. 4. reimp.São Paulo: Edusp, 2008.

SANTOS, M.; RIBEIRO, A. C. T. O conceito de região concentrada. Universidade Federal do Rio de Janeiro, Ippur e Departamento de Geografia, mimeo, 1979.

SANTOS, M.; SILVEIRA, M. L. O Brasil: território e sociedade no início do século XXI. 9. ed. Rio de Janeiro: Record, 2006.

SAROLDI, L. C.; MOREIRA, S. V. Rádio Nacional: o Brasil em sintonia. 3. ed. Rio de Janeiro: Jorge Zahar, 2005.

SAUAIA, A. C. A.; KALLÁS, D. O dilema cooperação-competição em mercados concorrenciais: o conflito do oligopólio tratado em um jogo de empresas. Revista de Administração Contemporânea, v. 11, n. especial, p.77-101. Disponível em: <http://www.scielo.br/scielo. php? pid $=$ S1415 $-65552007000500005 \&$ script $=$ sci_arttext $>$. Acesso em: 28 out. 2015. 
SCHAFF, A. A Sociedade Informática: as consequências sociais na segunda revolução industrial. Tradução de Carlos Eduardo Jordão Machado e Luiz Arturo Obojes. 4 ed. São Paulo: Unesp: Brasiliense, 1995.

SCHIFER, C.; PORTO, R. Telecomunicaciones: marco regulatório. Buenos Aires: El Derechi, 2002.

SCHUMPETER, J. A. Teoria do desenvolvimento econômico: uma investigação sobre lucros, capital, crédito, juro e o ciclo econômico. Tradução de Maria Sílvia Possas. São Paulo: Abril Cultural, 1982.

SERCOMTEL. Nossa empresa. Disponível em: <http://www.sercomtel. com.br/portalSercomtel/empresa.home.do>. Acesso em: 28 out. 2015.

SERPA, A. Lugar e mídia. 1 ed. São Paulo: Contexto, 2011.

SKY. A empresa/Quem somos. Disponível em: <http://www.sky.com.br/ institucional/Empresa/QuemSomos.aspx>. Acesso em: 28 out. 2015. SILVA, F. S.; TOLEDO JUNIOR, R. Lógicas territoriais das redes de telefonia móvel no Brasil. Disponível em: <http://www.agb.org.br/ evento/download.php?idTrabalho=2792>. Acesso em: 28 out. 2015.

SILVEIRA, M. L. Um país, uma região. Fim de século e modernidades na Argentina. Formação, Presidente Prudente, v. 1, n. 6, p.65-74, 1999a. . Um país, uma região: fim de século e modernidades na Argentina. São Paulo: FAPESP/LABOPLAN-USP, 1999b.

. Por uma teoria do espaço latino-americano. In: LEMOS, A. I. G.; SILVEIRA, M. L.; ARROYO, M. M. (Orgs.). Questões territoriais na América Latina. Buenos Aires: Clacso, São Paulo: Universidade de São Paulo, 2006. p.85-100.

SILVEIRA, M. R. A importância geoeconômica das estradas de ferro no Brasil. 454 f. 2003. Tese (Doutorado em Geografia) - Faculdade de Ciências e Tecnologia, Universidade Estadual Paulista, Presidente Prudente.

SMITH, N. Desenvolvimento desigual. 13 ed. Rio de Janeiro: Betrand Brasil, 1988.

SOJA, E. Geografias pós-modernas: a reafirmação do espaço na teoria social crítica. 7 ed. Rio de Janeiro: Jorge Zahar, 1993.

SPOSITO, E. S. Território, logística e mundialização do capital. In: SPOSITO, E. S (Org.) Dinâmica econômica, poder e novas territorialidades. Presidente Prudente: FCT/Unesp, GAsPERR, 1999. Geografia e Filosofia: contribuição para o ensino do pensamento geográfico. São Paulo: Editora Unesp, 2004. Redes e cidades. São Paulo: Unesp, 2008. 
SPOSITO, E. S.; BERNARDES, A. H. Da organização às relações: espaço virtual em questão. O exemplo do sistema de telefonia móvel celular em Presidente Prudente-SP. Geografia, Rio Claro, v. 34, n. 1, p.63-75, 2009.

SPOSITO, E. S.; JURADO DA SILVA, P. F. Cidades pequenas: perspectivas teóricas e transformações socioespaciais. Jundiaí: Paco Editorial, 2013.

STORPER, M.; WALKER, R. The capitalist imperative. Territory technology and industrial growth. New York e Cowley Road: Basil Blackwell, 1989.

SWEEZY, P.M. Demand under conditions of oligopoly. Journal of Political Economy, v. 47, n. 4 p.568-573, 1939. Disponível em: <http:// www.jstor.org/stable/1824594>. Acesso em: 28 out. 2015.

TATSCH, C. R. Privatização do setor de telecomunicações no Brasil. 2003. 318 f. Dissertação (Mestrado em Economia) - Faculdade de Ciências Econômicas, Universidade Federal do Rio Grande do Sul, Porto Alegre.

TELEBRAS. Telebras e IslaLink formam parceria para cabo submarino Brasil-Europa. Disponível em: <http://www.telebras.com.br/ inst $/$ p $=5272>$. Acesso em: 28 out. 2015.

. Histórico. Disponível em: <http://www.telebras.com.br/ inst/?page_id=41>. Acesso em: 28 out. 2015.

TELEBRASIL. Associação Brasileira de Telecomunicações. Disponível em: $<$ http://www.telebrasil.org.br/>. Acesso em: 28 out. 2015.

TELECO. Informações sobre o uso da internet no Brasil. Disponível em: $<$ http://www.teleco.com.br>. Acesso em: 28 out. 2015.

Informação sobre operadoras de televisão por assinatura. Disponível em: <http://www.teleco.com.br/operadoras/embratel.asp.> Acesso em 28 out. 2015.

Informação sobre internet. Disponível em: <http://www.teleco. com.br/internet.asp>. Acesso em: 28 out. 2015.

Informação sobre banda larga. Disponível em: <http://www. teleco.com.br/blarga.asp>. Acesso em: 28 out. 2015.

Internet no Brasil - Provedores. Disponível em: <http://www. teleco.com.br/internet_prov.asp>. Acesso em: 28 out. 2015.

Telefonia celular no Brasil. Disponível em: <http://www.teleco. com.br/DVD/PDF/tutorialcelb.pdf>. Acesso em: 28 out. 2015.

ERB por UF (Anatel: Maio/2013). Disponível em: <http:// www.teleco.com.br/erb.asp>. Acesso em: 28 out. 2015. 
Gerações de Sistemas Celulares. Disponível em: <http://www. teleco.com.br/tecnocel.asp>. Acesso em: 28 out. 2015.

Cobertura das Operadoras e População Atendida. Disponível em: $<$ http://www.teleco.com.br/cobertura.asp $>$. Acesso em: 28 out. 2015.

. Operadoras de Celular no Brasil. Disponível em: < http://www. teleco.com.br/opcelular.asp>. Acesso em: 28 out. 2015.

Informações sobre a Vivo. Disponível em: <http://www.teleco. com.br/operadoras/vivo.asp>. Acesso em: 28 out. 2015.

Informações sobre a Portugal Telecom. Disponível em: <http:// www.teleco.com.br/operadoras/ptelecom.asp>. Acesso em: 28 out. 2015.

Market Share das Operadoras de Celular no Brasil. Disponível em: em: <http://www.teleco.com.br/mshare.asp>. Acesso em: 28 out. 2015.

Seção: Telefonia fixa. Disponível em: <http://www.teleco.com. br/Operadoras/Telefonica.asp>. Acesso em: 28 out. 2015.

Seção: TV por assinatura. Disponível em: <http://www.teleco. com.br/operadoras/sky.asp>. Acesso em: 28 out. 2015.

. Sky. Disponível em: <http://www.teleco.com.br/operadoras/ sky.asp>. Acesso em: 28 out. 2015.

. Seção: Tutoriais Regulamentação. Disponível em: < http://www. teleco.com.br/tutoriais/tutorialmbassin/pagina_3.asp>. Acesso em: 28 out. 2015.

TELECOM ITÁLIA. Geographical dispersion. Disponível em: <http:// www.telecomitalia.com/tit/it/about-us/geographical-dispersion. html>. Acesso em: 28 out. 2015.

TELEFÔNICA/VIVO. Quem somos? Disponível em: < http://www. telefonica.com.br/institucional/sobre-a-telefonica/quem-somos>. Acesso em: 28 out. 2015.

Quem somos? Disponível em: <http://telefonica.mediagroup. com.br/pt/Empresa/Perfil.aspx>. Acesso em: 28 out. 2015.

Desempenho operacional. Disponível em: <http://telefonica. mediagroup.com.br/pt/Info_Mercado/Desempenho_Operacional. aspx>. Acesso em: 28 out. 2015.

TELEGEOGRAPHY. Tráfego global de ligações telefônicas, 2010. Disponível em: <http:// www.telegeography.com>. Acesso em: 28 out. 2015. 
. Submarine Cable Map. Disponível em: <http://www.submarinecablemap.com/\#/>. Acesso em: 28 out. 2015.

Submarine Cable Map 2014. Disponível em: <http://submarine-cable-map-2014.telegeography.com/>. Acesso em: 28 out. 2015.

TERRA. Portal Terra e como tudo começou. Disponível em: <http:// tecnologia.terra.com.br/internet10anos/interna/0,,OI542329 -EI5029,00.html>. Acesso em: 28 out. 2015.

. Sobre o Terra. Disponível em: <http://publicidade.terra.com.br/ index.php/pagina/visualizar/1>. Acesso em: 28 out. 2015.

TIM. Perfil da companhia. Disponível em: <http://tim.riweb.com.br/ show. aspx? $\mathrm{idCanal}=9 \mathrm{ROHtD} 3 \mathrm{EH}+7 \mathrm{QuGpf} 7 \mathrm{dfD} 3 \mathrm{~g}==>$. Acesso em: 28 out. 2015.

TOLEDO JUNIOR, R. Telecomunicações e uso do território brasileiro. In: SOUZA, M. A. A. (Org.). Território brasileiro: usos e abusos. Campinas: Edições Territorial, 2003. p.93-107.

TORRES, R. M. M. O mercado de TV por assinatura no Brasil: crise e reestruturação diante da convergência tecnológica. 2005. 169 f. Dissertação (Mestrado em Comunicação) - Centro de Estudos Gerais, Universidade Federal Fluminense, Niterói.

TOZI, F. As privatizações e a viabilização do território como recurso. 2005. 184 f. Dissertação (Mestrado em Geografia) - Instituto de Geociências, Universidade de Campinas, Campinas.

TROTSKY, L. A história da Revolução Russa. Tradução de E. Huggins. Rio de Janeiro: Editora Saga, 1967. v. 1.

Peculiaridades do desenvolvimento da Rússia. In: TROTSKY, L. A história da Revolução Russa. Rio de Janeiro: Paz e Terra, 1978, p.23-33.

UOL. UOL Inc. compra o Sinectis, $3^{\circ}$ maior provedor da Argentina. Disponível em: <http://noticias.uol.com.br/economia/ultnot/2001/09/12/ ult82u2635.jhtm>. Acesso em: 28 out. 2015.

Informação sobre o UOL. Disponível em: <http://sobreuol.noticias.uol.com.br/>. Acesso em: 28 out. 2015.

Informação sobre o UOL. Disponível em: < http://imprensa.uol. com.br/>. Acesso em: 28 out. 2015.

URUGUAI. Lei número 17.296. Disponível em: <http://www.parlamento.gub.uy/leyes /Acceso TextoLey.asp?Ley=17296\&Anchor $=>$. Acesso em: 28 out. 2015.

VALOR ECONÔMICO. Dona da operadora de TV Sky tem alta de $31 \%$ no lucro trimestral. Disponível em: <http://www.valor.com.br/ 
empresas/3005302/dona-da-operadora-de-tv-sky-tem-alta-de-31-no-lucro-trimestral>. Acesso em: 28 out. 2015.

Tele Norte Leste Participações aprova incorporação pela futura Oi S.A. Disponível em <http://www.valor.com.br/empresas/2544496/ tele-norte-leste-participacoes-aprova-incorporacao-pela-futura-oi-sa>. Acesso em: 28 out. 2015.

VEJA. Comissão Europeia vai investir 50 milhões de euros na tecnologia 5G. Disponível em: <http://veja.abril.com.br/noticia/vida-digital/ comissao-europeia-vai-investir-50-milhoes-de-euros-na-tecnologia-5g--2>. Acesso em: 28 out. 2015.

. Lucro da Telefônica Vivo cresce 2,2\% em 2012. Disponível em: $<$ http://veja.abril.com.br/noticia/economia/lucro-da-telefonica-vivo-cresce-apenas-2-2-em-2012>. Acesso em: 28 out. 2015.

Telefónica torna-se sócia majoritária da controladora da TIM. Disponível em: <http://veja.abril.com.br/noticia/economia/telefonica-torna-se-socia-majoritaria-da-controladora-da-tim>. Acesso em: 28 out. 2015.

Acordo entre Telefónica e TIM escancara concentração do setor de telefonia no Brasil. Disponível em: <http://veja.abril.com.br/noticia/ economia/acordo-entre-telefonica-e-tim-escancara-concentracao-do-setor-de-telefonia-no-brasil>. Acesso em: 28 out. 2015.

VIVO. Canais Vivo TV. Disponível em: <http://www.vivotv.tv.br/ CanaisDth>. Acesso em: 28 out. 2015.

WIKICOM. Ministério das Comunicações. Disponível em: <http:// wikicom.mc.gov.br/index.php/Minist\%C3\%A9rio_das_ Comunica\%C3\%A7\%C3\%B5es>. Acesso em: 28 out. 2015.

WIKIPEDIA. Informações sobre o Terra. Disponível em: <http:// en.wikipedia.org/wiki/Terra_Networks>. Acesso em: 28 out. 2015.

YIN, R. K. Case study research: design and methods. 3. ed. Thousand Oaks: Sage Publications, 2003.

YPILANTIL, D. Telecommunication and regional development, some issues for OECD members countries. In: BAKIS, H. (Org.). Communications et territoires. 1 ed. Paris: La Documentation Française, 1990, v. 1. p.297-303.

ZOOK, M.; DODGE, M.; AOYAMA, Y.; TOWNSEND. New Digital Geographies: information, communication, and place. In: BRUNN, S. D.; CUTTER, S.L.; HARRINGTON, J.W. (Eds.). Geography and Technology. Norwell: Kluwer Academic Publishers, 2004. 
SOBRE O LIVRO

Formato: $14 \times 21 \mathrm{~cm}$

Mancha: $23,7 \times 42,5$ paicas

Tipologia: Horley Old Style 10,5/14

\section{EQUIPE DE REALIZAÇÃO}

Coordenação Geral

Atarukas Studio 